UNIVERSIDADE DE SÃO PAULO

FACULDADE DE FILOSOFIA, LETRAS E CIÊNCIAS HUMANAS

PROGRAMA DE PÓS-GRADUAÇÃO EM HISTÓRIA SOCIAL

PEDRO LUÍS DE TOLEDO PIZA

PELA UNIDADE DA IGREJA: INÁCIO DE ANTIOQUIA E O MONEPISCOPADO NA PROVÍNCIA ROMANA DA ÁSIA

SÃO PAULO 
PEDRO LUÍS DE TOLEDO PIZA

\section{PELA UNIDADE DA IGREJA: INÁCIO DE ANTIOQUIA E O MONEPISCOPADO NA PROVÍNCIA ROMANA DA ÁSIA}

Dissertação apresentada ao Programa de Pósgraduação em História Social da Faculdade de

Filosofia, Letras e Ciências Humanas, da Universidade de São Paulo, para obtenção do título de Mestre em História Social.

Agência financiadora: FAPESP

Orientador: Prof. Dr. Norberto Luiz Guarinello

\section{SÃO PAULO}


Autorizo a reprodução e divulgação total ou parcial deste trabalho, por qualquer meio convencional ou eletrônico, para fins de estudo e pesquisa, desde que citada a fonte.

\section{Catalogação na Publicação}

Serviço de Biblioteca e Documentação

Faculdade de Filosofia, Letras e Ciências Humanas da Universidade de São Paulo

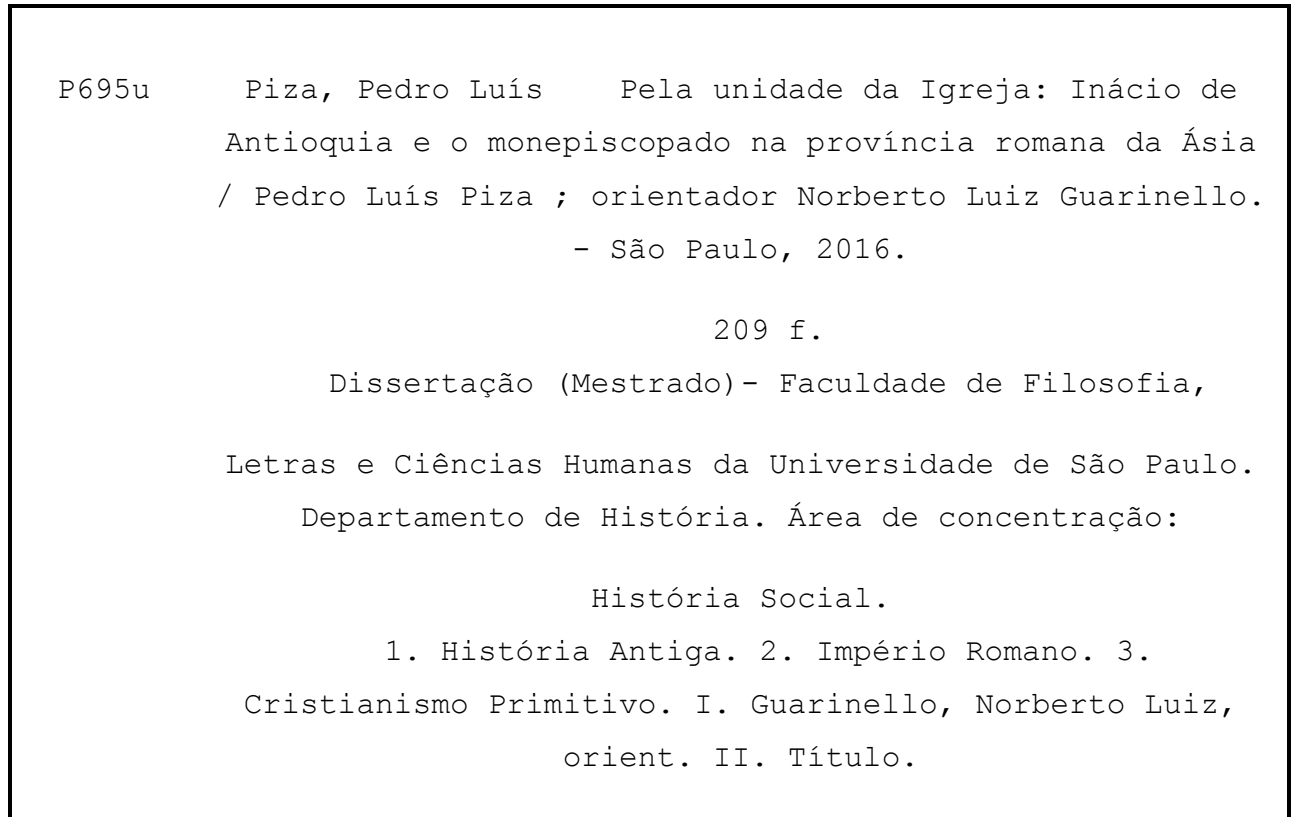


Nome: PIZA, Pedro Luís de Toledo

Título: Pela unidade da Igreja: Inácio de Antioquia e o monepiscopado na província romana da Ásia

Dissertação apresentada à Faculdade de Filosofia Letras e Ciências Humanas da Universidade de São Paulo para obtenção do título de Mestre em História Social em:

\section{Banca Examinadora}

Prof. Dr. Instituição: Julgamento:

Assinatura:

Prof. Dr. Instituição: Julgamento:

Assinatura:

Prof. Dr. Instituição: Julgamento:

Assinatura: 
Dedico este trabalho a Ana Maria e Célio (in memoriam), mestres na arte de viver e amar:

"Ser criado, gerar-se, transformar

O amor em carne e a carne em amor; nascer

Respirar, e chorar, e adormecer

E se nutrir para poder chorar

Para poder nutrir-se; e despertar

Um dia à luz e ver, ao mundo e ouvir

E começar a amar e então sorrir

E então sorrir para poder chorar.

E crescer, e saber, e ser, e haver

E perder, e sofrer, e ter horror

De ser e amar, e se sentir maldito

E esquecer tudo ao vir um novo amor

E viver esse amor até morrer

E ir conjugar o verbo no infinito..."

(VINICIUS DE MORAES, “O verbo no infinito”) 


\section{Agradecimentos}

Os últimos três anos foram um tempo de trabalho árduo. Alcançar o objetivo final me leva automaticamente a pensar em todos aqueles que possibilitaram que o presente estudo pudesse existir.

Antes de tudo, agradeço muitíssimo o apoio financeiro prestado pela Fundação de Amparo à Pesquisa do Estado de São Paulo (FAPESP), sem o qual a pesquisa não poderia ter sido concluída com sucesso. $\mathrm{O}$ financiamento me permitiu ir a congressos, adquirir material, dedicar-me unicamente ao trabalho de pesquisa e, sobretudo, visitar centros tão destacados de conhecimento como o são a Universidade de St. Andrews, na Escócia, e a Universidade Humboldt de Berlim, na Alemanha, trazendo resultados preciosos para a profissão e para a vida.

Por onde o olho passar na presente dissertação, certamente haverá uma marca da preciosa orientação do Prof. Dr. Norberto Luiz Guarinello, o qual possibilitou que algumas indagações de um estudante ao fim da graduação pudessem se transformar em um estudo de História Social. Agradeço sobretudo pelas orientações de pesquisa, pelas recomendações e críticas, assim como pela ajuda inestimável na construção da estrutura da dissertação. Se ela existe, é devido ao seu auxílio.

Ao Prof. Dr. Carlos Augusto Ribeiro Machado, à sua família, Elizabeth O’Keefe, seus lindos filhos, José e Patrick, digo com toda a sinceridade: jamais poderei agradecerlhes à altura pelo auxílio que me deram durante minha curta (porém, inesquecível) passagem por St. Andrews. Sua presteza incrível transformou o que era, até então, uma aventura perturbadora, em dias muito agradáveis em um ambiente familiar. O mesmo digo a Sarah Lino Azevedo, cuja ajuda e cujo teto me permitiram concluir uma (breve) pesquisa em um local inicialmente estranho.

Agradeço também a todos os pesquisadores que integram o LEIR-MA/USP, por nossos colóquios quase semanais. Todos, sem exceção, são para mim modelos de historiadores e estudiosos, completamente abertos a uma boa conversa, sobre literalmente qualquer assunto. Agradeço, de forma especial, ao Dr. Matheus Coutinho Figuinha, muito amigo historiador, que me brindou com sua convivência no mesmo laboratório, assim como com sua presença em minha banca de Qualificação. Seus conselhos preciosos também permitiram que esta dissertação fosse realidade.

Durante a minha trajetória de pesquisa no Mestrado, muitas foram as contribuições por parte de professores. De início, preciso dedicar um agradecimento 
especial à Profa. Dra. Rossana Baptista Alves Pinheiro por seu inestimável apoio na criação do projeto inicial que desembocou neste trabalho. Do mesmo modo, agradeço aos conselhos e às aulas do Prof. Dr. Carlos Alberto de Moura Ribeiro Zeron, o qual contribuiu muito para as orientações metodológicas do estudo. Por fim, uma palavra especial de agradecimento ao Prof. Dr. Júlio César Magalhães de Oliveira, que deu uma contribuição fundamental ao andamento do trabalho quando de sua participação em minha banca de Qualificação, especialmente na estruturação da dissertação e em suas observações quanto aos sentidos do texto que eu estava construindo.

A convivência com os amigos também garantiu que o trabalho fosse executado com sucesso. Com sua mera presença eles contribuíram para que o trabalho fosse menos árduo. Agradeço de forma especial Thiago Tigre de Souza, Yuri Alvarenga Oliveira, Tamires Martins, Nathália Lobato e Irene Antunes Garcia, verdadeiros amigos para toda hora. Agradeço também Raphael Martinelli Barelli pelos conselhos, assim como a Rodolpho Rabello da Rocha e Débora Villela de Oliveira pelo mesmo motivo, especialmente neste tempo em que Mônica veio ao mundo.

Quero dedicar um todo especial a Caroline, minha companheira e melhor amiga, que me acompanhou de perto durante todo o período de pesquisa, mesmo nos momentos em que eu me encontrava longe. Sua atenção e paciência suavizaram consideravelmente o caminho árduo, seus conselhos permitiram que a própria pesquisa existisse, seu carinho garantiu que eu não me desviasse do objetivo. Espero que esta dissertação possa enchêla de orgulho, assim como eu sempre me orgulho dela. Agradeço também a seus pais, dona Rose e seu Elias, cujo teto me abrigou inumeráveis vezes, sob ele ocorrendo parte do próprio trabalho de pesquisa.

Agradeço muitíssimo a meu irmão, Luís Gabriel de Toledo Piza, pela convivência muito agradável nos últimos anos, enfrentando as agruras do dia-a-dia. Nossas conversas contribuíram de forma definitiva para o resultado final.

Nunca é demasiado dizer que tudo o que sou se deve ao esforço e à atenção de meus pais. O mesmo pode ser dito desta dissertação: ela simplesmente não existiria sem o seu apoio. Ela é um acréscimo à lista de coisas pelas quais nunca poderei retribuir à altura, sendo o próprio dom da vida a primeira. Apenas posso expressar, uma vez mais, o meu agradecimento por tudo o que são para mim, assim como espero poder ser-lhes sempre todo possível.

Por fim, agradeço humildemente ao Mestre por seus ensinamentos, que me fizeram quem sou e me deram o dom da perseverança diária para concluir este trabalho. 


\section{Resumo}

A passagem dos séculos I e II d.C. assistiu ao desenvolvimento de um cristianismo dinâmico na província romana da Ásia Proconsular, na costa egeia da Ásia Menor. Concomitante à ascensão política e econômica da região no contexto do Mediterrâneo em pleno Alto Império Romano, as comunidades cristãs locais apresentam um prolífico quadro doutrinal e ritual, o qual lhes confere destaque e as torna destinatárias da maior parte do curto epistolário de um personagem histórico tão marcante quanto enigmático: Inácio de Antioquia, que afirma ser o supervisor da igreja presente na grande metrópole síria, e que passa pela Ásia acorrentado a um pelotão de soldados, rumo à capital romana, para lá ser supostamente executado na arena. As cartas de Inácio sugerem a existência, em comunidades presentes em centros urbanos importantes da província, de um corpo de líderes fixos, dentre os quais destacando-se a figura de um único supervisor, do qual o prisioneiro defende a autoridade sobre todos os cristãos de uma mesma cidade. Uma análise de documentos datados de antes da composição do breve epistolário inaciano não oferece, contudo, bases para a afirmação de uma perenidade de tal forma de governo das comunidades cristãs asiáticas. Ao invés, uma leitura atenta das fontes aponta para um processo social de ligeira alteração dos referenciais de autoridade, de modo que, sobretudo após a morte do apóstolo Paulo de Tarso (principal fundador do cristianismo na Ásia Proconsular), um valor singular é dado a líderes homens que sejam reconhecidos publicamente como bons chefes de households. Nesse processo Inácio de Antioquia procura tomar parte, de modo a solidificar a autoridade do supervisor por meio de um incremento do alcance de seu controle social: ele prega, com autoarrogada autoridade profética, que o encarregado da supervisão da comunidade seja visto como a própria representação da figura divina e patriarcal de Deus Pai, e que apenas sob ele uma reunião ritual pode ser considerada válida.

Palavras-chave: Inácio de Antioquia; Monepiscopado; Província da Ásia Proconsular; Mediterrâneo Romano; Cristianismo Primitivo. 


\begin{abstract}
The transit from the first to the second century CE saw the development of a dynamic Christianity in the Roman province of Asia Proconsularis, on the Aegean Asia Minor coast. Concomitant to the political and economic ascension of the region in the context of the Mediterranean, in plain Early Roman Empire, the local Christian communities show a prolific doctrinal and ritual frame, which give them highlighted status, and make them the recipients of most of the short epistolary of a historical character so outstanding as enigmatic: Ignatius of Antioch, who claims to be the overseer of the church in the great Syrian metropolis, and which goes through Asia bonded to a band of soldiers in way to the Roman capital, where he should, supposedly, be executed in the arena. The letters of Ignatius suggest the existence, in communities existent in the province's main urban centers, of a group of fixed leaders, from which is detached the figure of the sole overseer. This overseer's authority, the prisoner says, is extended over all the Christians living in a same city. However, an analysis of the documents dated from before the composition of the short Ignatian epistolary, do not offer basis to the affirmation of perennial status of such a way in governing the Asiatic Christian communities. To the contrary, a careful reading of the sources directs to a slight social process of change in the references of authority, in such a way that, especially after the death of the apostle Paul of Tarsus (main founder of Christianity in Asia Proconsularis), a special value is given to men leaders publicly recognized as good household chiefs. Ignatius of Antioch attempts to have a part in this process with the aim of solidifying the authority of the overseer by incrementing the range of his social control; he preaches, with selfproclaimed prophetic authority, that the one charged with community overseeing should be seen as the very representation of the divine and patriarchal figure of God the Father, and that only under him a ritual reunion could be considered as valid.
\end{abstract}

Keywords: Ignatius of Antioch; Monepiscopacy; Province of Asia Proconsularis; Roman Mediterranean; Early Christianity. 


\section{SUMÁRIO}

INTRODUÇÃO

CAPÍTULO 1 - AMBIENTAÇÃO GERAL: O CRISTIANISMO ASIÁTICO ANTIGO EM SEU CONTEXTO SOCIAL, POLÍTICO E ECONÔMICO.

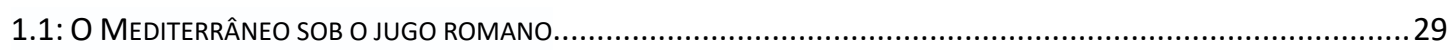

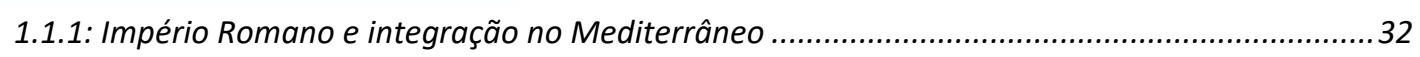

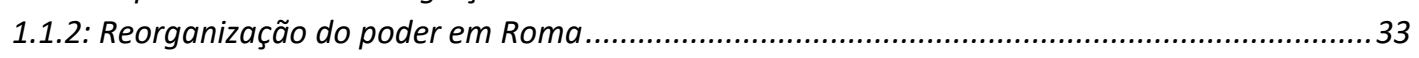

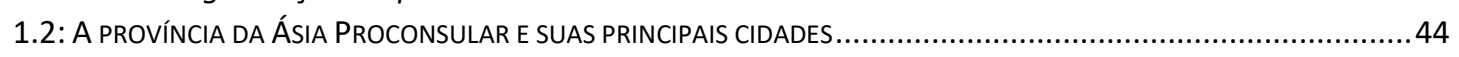

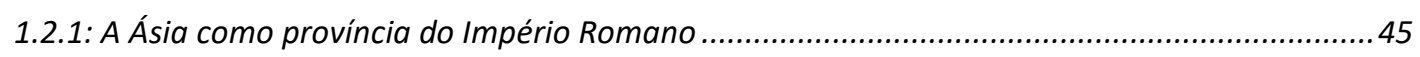

1.2.2: Sociedade e economia na província da Ásia Proconsular ....................................................51

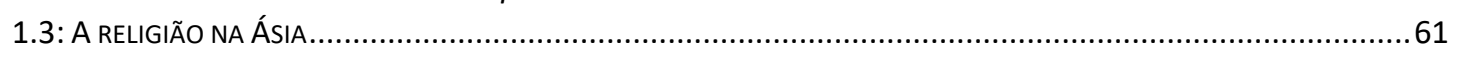

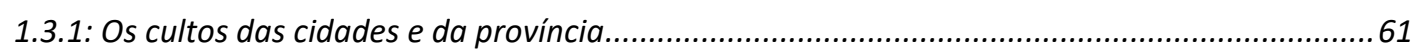

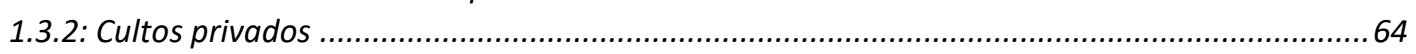

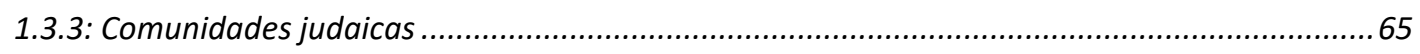

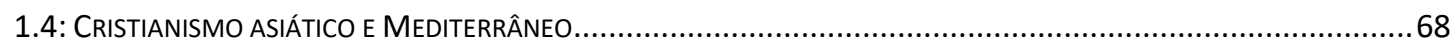

CAPÍTULO 2 - O CRISTIANISMO ASIÁTICO E SUAS LIDERANÇAS, DE SUA FUNDAÇÃO A 100 D.C. ..........70

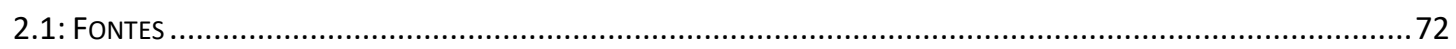

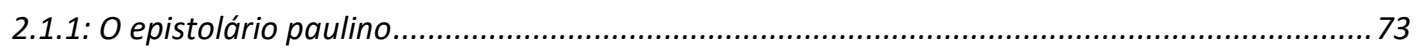

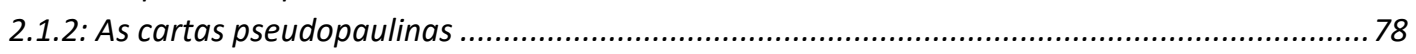

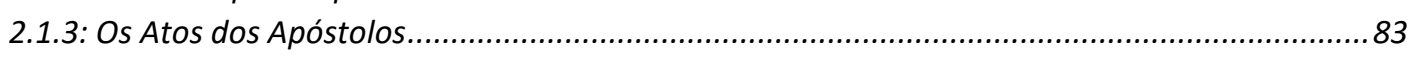

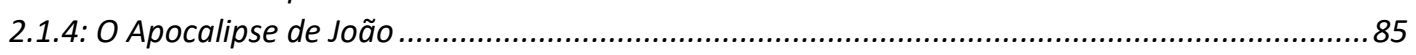

2.1.5: Fontes correntemente utilizadas pelos estudiosos, mas que apresentam problemas de

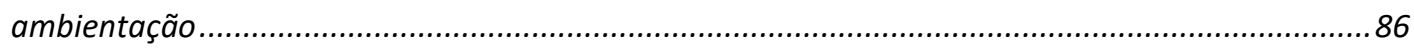

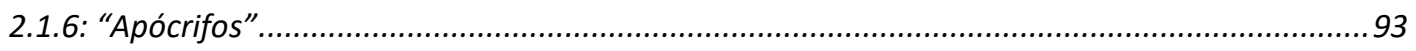

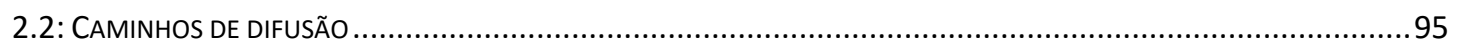

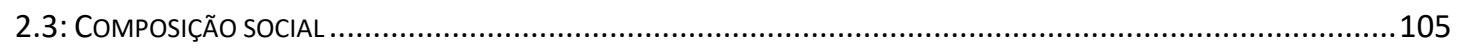

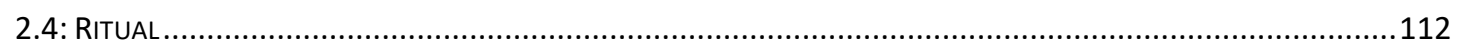

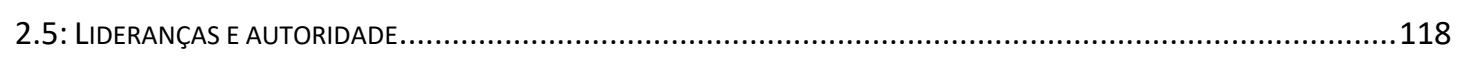

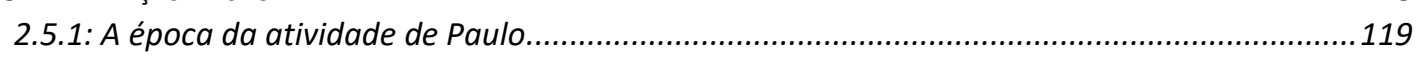

2.5.2: Narrativas sobre o passado, considerações sobre o presente: Os Atos dos Apóstolos...........128

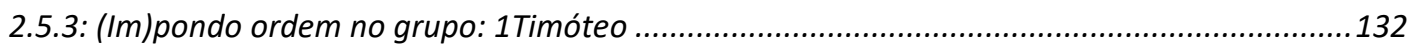

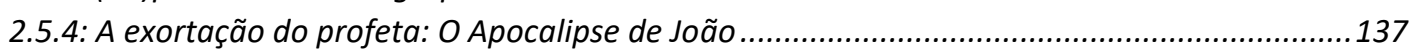

2.5.5: Observações finais sobre as lideranças na comunidade ....................................................138

CAPÍTULO 3: INÁCIO DE ANTIOQUIA E O SUPERVISOR ÚNICO DA COMUNIDADE CRISTÃ ...................141

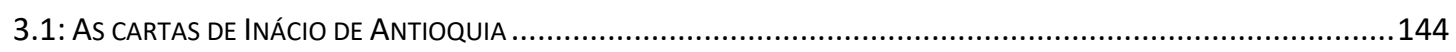

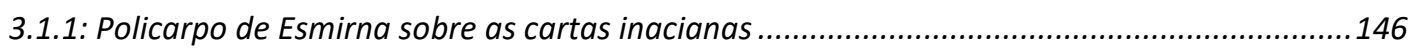

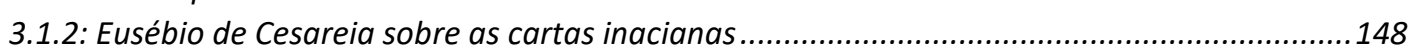

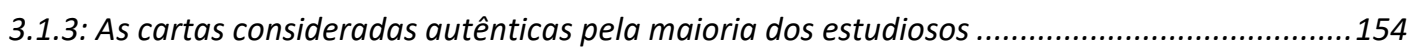

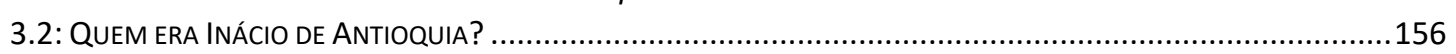

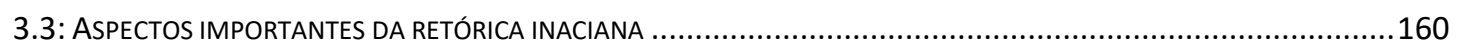

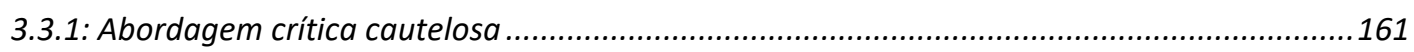

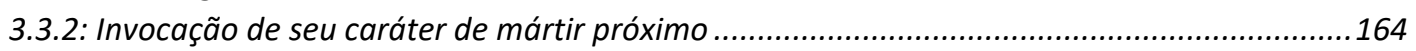

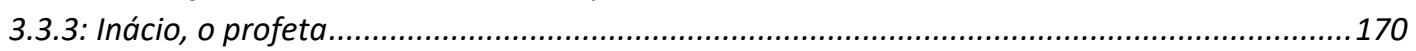

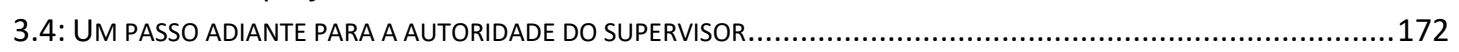

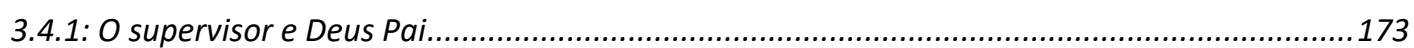

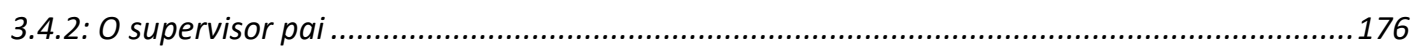

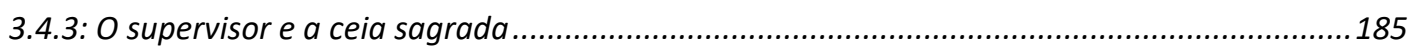

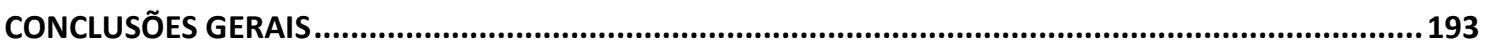


BIBLIOGRAFIA. 


\section{Introdução}

E quanto mais alguém vê que o supervisor se mantém em silêncio ( $\tau 1 \zeta$

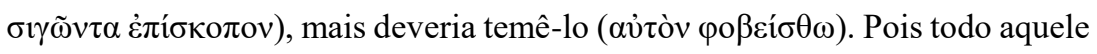

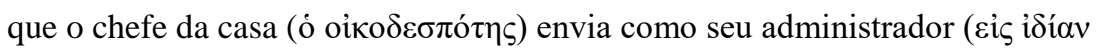
oíкоvонíav), deve ele ser recebido como se fosse aquele que o enviou. Certamente, portanto, deve o supervisor ser considerado como o próprio

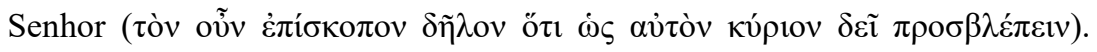
(In.Efésios 6,1)

O autor das palavras acima foi um homem chamado Inácio de Antioquia, um cristão da virada dos séculos I e II d.C. que encontrava-se preso no momento que escrevia a grupos de seus correligionários, presentes em cidades da antiga província romana da Ásia Proconsular. É ele o autor das sete cartas que servem de fonte principal para a presente dissertação, fruto de um trabalho de pesquisa desenvolvido durante o desenrolar de três anos, nos quais investiguei os meios pelos quais Inácio, por meio da documentação por ele produzida, visou contribuir para um reforço do que ele enxergava como a unidade ideal das igrejas para as quais escreveu. No entanto, o trecho citado logo de início não foi escolhido tanto por ser representativo de uma forma típica de Inácio expressar suas ideias (de fato, algumas delas são bem peculiares ao dito trecho, como a representação do

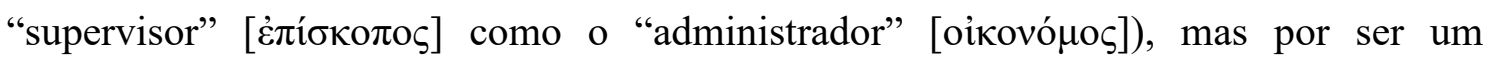
sugestivo das maneiras pelas quais o autor foi (muito) abordado até hoje pela historiografia.

De fato, Inácio de Antioquia é um dos principais atores históricos por trás de uma série de trabalhos acadêmicos sobre os primeiros séculos do cristianismo, compostos sobretudo a partir da primeira metade do século XIX e alcançando nossos dias. Neles, a imagem que, usualmente, se destaca de nossa fonte é a de um representante de uma tendência monárquica de exercício de autoridade dentro das primeiras comunidades cristãs, sendo frequentemente colocado em contraposição ao ideal igualitário e democrático de convivência comunitária das duas ou três décadas que sucederam a morte de Jesus de Nazaré em Jerusalém. Em outras palavras, Inácio seria um representante (assim como, também, uma representação) do “episcopado monárquico" que viria a viger na Igreja sobretudo a partir de meados do século II d.C., em detrimento de outras formas antigas e carismáticas de liderança, como apóstolos e profetas itinerantes. Bem representativo de tal forma de construção narrativa é o que diz W.H.C. Frend a respeito 
do antioqueno, ao comparar o conteúdo de suas cartas com as autoridades itinerantes por ele percebidas em documentos anteriores:

The future lay with the resident clergy, and by A.D. 100 in Antioch and among many of the communities in Asia Minor and on the Greek mainland the bishop with his priests and deacons was in control. Ignatius, traveling through the cities of western Asia Minor, shows that Polycarp had already began his long reign (!) in Smyrna, and that bishops were in authority in the other towns which he visited. His own claimant emphasis on episcopacy could not have been wholly unrepresentative of the Christian scene. With the recession of the Second Coming into the distant future (see 2 Peter 3:3-4) the way was open for the bishop, assisted by his presbyters and deacons, to become the norm of Christian government throughout the Greco-Roman world. (FREND, 1991: 41; grifo meu)

Uma série de pontos merecem ser levantados a partir da afirmação de Frend. Podemos notar, de início, uma linearidade histórica em sua narrativa: existem duas ordens de coisas, uma sucedendo à outra. Existe um primeiro momento no qual ministros itinerantes exercem funções de liderança com relação às diversas comunidades cristãs. Em um segundo momento, tal forma de organização da autoridade é substituída por outra, na qual sobressai um "clero residente". Desta segunda ordem de coisas Inácio é representante, conforme a apresentação de Frend. No entanto, tal ordem já vem pronta, conforme o que é "norma" na Igreja a partir do século II d.C., isto é, que as comunidades cristãs sejam guiadas, individualmente, por um bispo, em conjunto com "padres/sacerdotes" (priests) e diáconos. A forma como Frend desenvolve a narrativa (na mesma tendência de muitas outras compostas por vários autores dos séculos XIX e XX) confere tons teleológicos à mesma: "o futuro resta com o clero residente", em um sentido quase que necessário, onde as formas antigas de liderança apenas poderiam fazer sentido em um contexto de recém-fundação da nova fé, com a espera iminente do fim do mundo que, obviamente, não pode ser identificada com a formação de meios de exercício de autoridade menos consonantes com dons de fala ou qualquer coisa parecida. Do mesmo

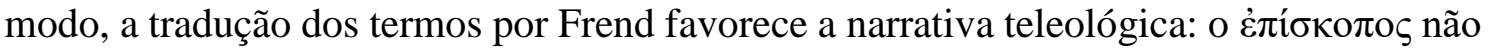
é um supervisor, conforme podemos traduzir literalmente o termo (também: "aquele que vê sobre [algo/alguém]"), e sim o "bispo", com todas as prerrogativas que lhe são inerentes, a ponto de ser possível dizer que, à época da passagem de Inácio pela Ásia, 
Policarpo "iniciava seu longo reinado", como se fosse um detentor do ofício episcopal em plena Idade Média. Em outras palavras, um bispo monárquico.

Outro autor mais direto, nesse sentido, é o renomado Henry Chadwick, grande estudioso dos primórdios do cristianismo. Do mesmo modo que Frend, Chadwick trata de Inácio de Antioquia em comparação com as mesmas fontes anteriores (no caso, 1Coríntios) que apresentariam, em sua visão, uma forma de ministério itinerante de mais livre acesso, com o reconhecimento, por parte da comunidade, da existência de certos dons especiais em um determinado membro:

Sixty or seventy years later Ignatius was speaking of Antioch and the Asian churches as possessing a monarchical bishop, together with presbyters and deacons. In his time there were neither apostles nor prophets. The exact history of this transition within two generations from apostles, prophets and teachers to bishop, presbyters and deacons is shrouded in obscurity, though our sources give occasional glimpses of the process. (CHADWICK, 1967: 46; grifo meu)

Apesar de colocar o processo histórico como "envolto em obscuridade", o livro de Chadwick ainda assim se mostra outro exemplo da mesma narrativa linear: existe uma primeira ordem de coisas que é sucedida (por meios "obscuros") por outra. Em um primeiro momento, existem apóstolos, profetas e mestres à frente das primeiras comunidades, conforme a leitura feita por ele da Primeira Carta aos Coríntios, de autoria de Paulo de Tarso; em um segundo momento, porém, tais figuras de autoridade são substituídas por bispo, presbíteros e diáconos. A grande diferença, contudo, encontra-se na primeira função da segunda ordem de coisas. Agora, conforme a leitura feita das cartas de Inácio, existe um "bispo monárquico" à frente de sua igreja. Sua mera existência aparenta espantar aqueles apóstolos e profetas que poderiam antes ser tão marcantes na vida das comunidades. Tanto Chadwick quanto Frend são representativos de uma forma de conceber o desenvolvimento histórico das formas de autoridade internas às primeiras comunidades cristãs, a qual é caracterizada por uma rápida e efetiva concentração de poder em uma única figura, o bispo, a ponto de tal modelo se impor já a partir do começo do século II d.C., com apenas cerca de sessenta anos de diferença do período em que Paulo ainda escrevia às igrejas por ele fundadas. Tal processo social é tanto obscuro quanto eficaz, uma vez que vem a consolidar o episcopado monárquico como a forma de 
organização do poder característica da Igreja mesmo (e sobretudo) após o reinado de Constantino, já na primeira metade do século IV d.C.

A leitura historiográfica usual aqui referida, contudo, começou a ser questionada já ao fim do século XX e no início do XXI, de modo que a versão segundo a qual Inácio de Antioquia representaria um novo estado da organização eclesial, na qual o bispo seria uma espécie de monarca da comunidade, teve seus fundamentos severamente atingidos. Um primeiro nome que podemos destacar neste movimento é o de William R. Schoedel, que publicou, em 1985, um vasto comentário, acompanhado de tradução própria, das sete cartas inacianas. Dos objetivos por ele propostos em seu trabalho, destaca-se o de se contrapor à tese de Robert Joly (discutida no capítulo 3 da dissertação), segundo o qual o fato de as cartas de Inácio de Antioquia serem representantes de um episcopado monárquico estabelecido tão cedo poderia apenas servir de argumento para uma rejeição da autenticidade dos ditos documentos, os quais deveriam ser considerados como falsificações da segunda metade do século II d.C. Schoedel, em seu comentário, propõe uma leitura diferente de Joly, na qual o que autor antigo expressa em palavras não é, necessariamente, a realidade com a qual se defronta, mas sim aquilo que idealiza de forma exortativa aos seus destinatários (SCHOEDEL, 1985: 7). Em outras palavras, Inácio de Antioquia, ao invés de ser uma testemunha primeva de um episcopado monárquico, deveria ser, no máximo, lido como um proponente do mesmo, não podendo ser exatamente um fiador daqueles grupos para os quais escreve.

Na mesma senda de Schoedel, Paul Trebilco, em seu volumoso estudo sobre a igreja presente na cidade de Éfeso, capital da província romana da Ásia Proconsular, foi além, questionando diretamente a aplicabilidade do conceito de "episcopado monárquico" a partir do que pode ser retirado das sete cartas inacianas:

The bishop then is far from an autocratic ruler and to at least some extent needs to work with the elders in particular in a collaborative way. We conclude that with Ignatius we have not gone as far along the road towards a "ruling bishop" (monarchical episcopacy) as is often thought. (TREBILCO, 2004: 642)

Ao questionar a leitura mais comum das cartas de Inácio acerca da função episcopal, Trebilco sugere substituir o antigo conceito de "episcopado monárquico", o qual sugere um bispo que se encontra em "uma relação estritamente hierárquica com relação aos presbíteros, diáconos e a congregação", pelo de "monepiscopado", que aponta 
para um bispo que pode ser um pouco mais que o líder de um grupo de presbíteros, sem existir necessariamente uma hierarquia entre as duas partes. Tal alteração conceitual, embora possa aparentar ser apenas um detalhe, subverte toda a leitura historiográfica clássica acerca do desenvolvimento das funções de liderança nas comunidades cristãs mais antigas. Afinal, aceitando as perspectivas de Schoedel e Trebilco, um estudioso do episcopado monárquico teria, a partir de agora, de buscar os inícios do mesmo em outro lugar e em outro período, que não o de Inácio de Antioquia.

A presente dissertação se pretende um questionamento de ambas as tendências historiográficas acima referidas. De fato, enquanto optamos pelo uso do conceito de "monepiscopado" no título do trabalho como expressão de aceitação dos questionamentos válidos levantados por Schoedel e Trebilco, não descartamos, de início, a possibilidade

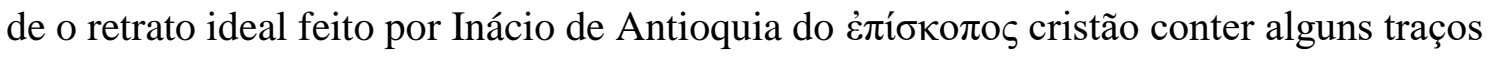
que poderiam ser considerados como tendentes a uma "monarquia" no âmbito da comunidade. Ao mesmo tempo, porém, questionamos o persistente pressuposto teleológico de que todo o processo flui necessariamente para a afirmação do episcopado monárquico característico da Igreja, sobretudo a partir da Antiguidade Tardia. Propomos,

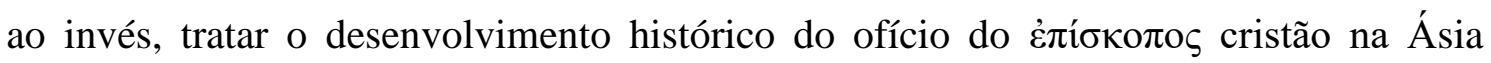
Proconsular em um dado recorte cronológico, a saber, da segunda metade do século I d.C. às primeiras décadas do outro século, quando da passagem de Inácio de Antioquia. $\mathrm{O}$ objetivo é tratar o referido desenvolvimento como um processo histórico social e, como tal, sem um fim certo que seja discernível a seus contemporâneos. Neste sentido, nossa fonte deixa de ser uma mera testemunha da existência de um "episcopado monárquico" ou de um "monepiscopado", para se tornar agente histórico integrando o processo, defendendo um ponto de vista e buscando estratégias para fazê-lo valer entre aqueles para os quais escrevia. Inácio de Antioquia não é nem um transmissor fiel de uma dada realidade, e nem um grande proponente de uma ordem completamente nova aos seus destinatários, mas sim um homem que, em sua exortação, visa dialogar com o já existente

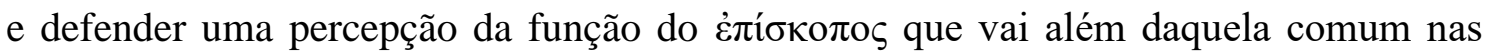
comunidades cristãs da Ásia.

Para fugir ao risco da leitura teleológica, um passo primordial é fugir à armadilha da tradução dos termos gregos em questão. Karen Jo Torjensen sintetiza perfeitamente o 
problema que atinge a maioria esmagadora dos trabalhos na área, inclusive os citados aqui:

Debate centres on whether these leaders were early versions of bishops. Others took on administrative ministries, caring for the sick, overseeing the poor, and securing training for orphans. Those exercising these ministries were designated as administrator or overseer (episkopos) and manager (diakonos). Those with responsibility for the group were designated elders (presbyteros). The question posed by such titles is: do these terms in the second century mean the same thing as they do in the fourth? (TORJENSEN, 2008: 397)

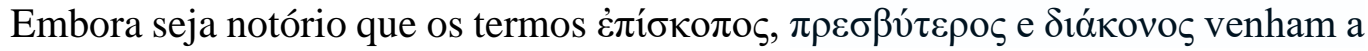
ser usados especificamente para a designação de cargos eclesiásticos, sobretudo a partir do século IV d.C. e com a sua transliteração para o latim (episcopus, presbyterus e diaconus), a sua tradução como, respectivamente, "bispo", "presbítero" e "diácono" deve ser, no caso do presente estudo, rejeitada em prol de uma outra mais literal e usual nas cidades de língua grega do Mediterrâneo: "supervisor", “ancião" e "servidor". Afinal, nenhuma das fontes cristãs, como é possível ser visto nos capítulos 2 e 3, sugerem uma noção restrita ao uso cristão de tais termos, ao mesmo tempo que sua utilização era frequente em outras formas de agrupamento social e religioso quando do nascimento do cristianismo, como em associações voluntárias e sinagogas.

Por outro lado, não deve ser ignorado o fato de que a separação entre cristãos que servem como "supervisor", "anciãos" e "servidores" é, necessariamente, um processo de formação de fronteiras sociais. Enquanto alguns membros podem ser e são líderes do grupo, outros não o são. Torjensen enxerga tal processo como parte de outro mais amplo, envolvendo os primeiros quatro séculos depois de Cristo, de distinção entre clero e laicado no interior do cristianismo. Fundamentando-se em Pierre Bourdieu, ela chama atenção para um processo sociológico onde "um grupo de especialistas religiosos se torna socialmente reconhecido como possuindo uma exclusiva e necessária perícia" e "monopoliza o culto por meio da exclusão daqueles que são constituídos como laicado, os não-qualificados nas doutrinas e removidos do sagrado". Neste sentido, Torjensen arremata: "Clergy and laity form a dyad; they are categories that emerge only in terms of their relationship to each other" (Ibidem: 389).

O presente estudo, no entanto, não pretende se focar na formação de um clero no interior do cristianismo da Ásia Proconsular, embora certamente sinais de tal processo 
sejam claramente perceptíveis em meio à análise da documentação. Nosso objetivo não é o de analisar a relação entre o supervisor cristão e os fieis comuns, mas sim estudar o desenvolvimento da função de supervisão como autoridade superior nas primeiras igrejas asiáticas, assim como a atividade de Inácio de Antioquia em meio a esse processo histórico. Neste sentido, vale algumas palavras referentes a uma conceituação do que seja, afinal, autoridade, assim como uma apresentação de duas formulações teóricas das formas pelas quais a autoridade se manifesta nos fenômenos sociais, uma mais geral e outra mais específica para o cristianismo dos primeiros séculos.

Uma definição de autoridade de necessária citação e sobre a qual nos fundamentaremos no presente estudo é a de Max Weber. Não que haja uma única definição clara em toda sua obra, já que Weber é conhecido por apresentar definições acerca da autoridade de formas ligeiramente diversas em diferentes trechos (KRONMAN, 2009: 59). No entanto, do balanço de sua obra podemos retirar a ideia de que autoridade seria uma espécie de manto de legitimação que envolve uma ou mais relações de dominação. Neste sentido, um trecho de sua obra Economia e Sociedade (no original alemão, Wirtschaft und Gesellschaft) oferece aquela que é, talvez, a mais clara definição de uma relação de autoridade:

In other words, in our terminology domination shall be identical with authoritarian power of command. To be more specific, domination will thus mean the situation in which the manifested 'rill (command) of the ruler or rulers is meant to influence the conduct of one or more others (the ruled) and actually does influence it in such a way that their conduct to a socially relevant degree occurs as if the ruled had made the content of the command the maxim of their conduct for its very own sake. Looked upon from the other end, this situation will be called obedience. (WEBER, 1978: 946)

Optamos por destacar tal definição weberiana de relação de autoridade por conta de sua reconhecida aplicabilidade no contexto do cristianismo nascente, onde formas de autoridade diversas florescem em vários cantos do Mediterrâneo antigo, definindo-se ou sendo definidas de formas igualmente diferentes, sendo, ao mesmo tempo, aceitas por ao menos parte dos grupos. A importante posição de Weber para os estudos sobre as formas cristãs antigas de liderança, assim como da passagem de um modelo para o outro, é reconhecida (e criticada) por James Tunstead Burtchaell, por exemplo (BURTCHAELL, 1992: 138-140). Por outro lado, a importância de uma construção ideal para a manutenção 
de um modelo de dominação social e econômica, por meio da aceitação dos submetidos, foi ressaltada, no campo antropológico, já na segunda metade do século XX por Maurice Godelier, em sua obra L'idéel et le matériel. No caso específico do fenômeno religioso, Godelier afirma que "a religião não constitui somente uma superfície, mas trata-se de algo como uma parte interna das relações econômicas e políticas, uma parte de sua armação interior" (GODELIER, 1984: 49).

Apesar da definição de Weber, sustentada pela tese de Godelier, ser muito útil como uma forma de pensarmos autoridade, devemos reconhecer que sua utilidade para o estudo é limitada. De fato, como pode ser visto sobretudo nos capítulos 2 e 3 , é mais fácil levantarmos as construções discursivas visando a legitimação de uma forma de liderança e dominação específica do que termos uma ideia concisa do nível de sua aceitação pela parte dirigida do grupo social em questão. Deste modo, a análise não visa retomar constantemente a teoria weberiana, mas sim apresentar uma forma prática de exercício (ou busca de exercício) de autoridade por parte dos atores históricos, tendo a teoria como uma forma de direcionamento e auxílio, e não como uma forma de engessar a narrativa. O mesmo pode ser dito das formas como a autoridade se manifesta. Neste caso, podemos fazer referência a dois teóricos para servirem de apoio.

O primeiro é o próprio Max Weber, para o qual existem apenas três formas de manifestação da autoridade em todos os agrupamentos sociais. A primeira é aquela por ele denominada "tradicional", fundamentada na "devoção àquilo que verdadeira, suposta ou presumidamente sempre existiu" (WEBER, 1978: 215). De fato, para Weber, uma autoridade só pode ser classificada como tradicional "se a sua legitimidade for alegada e obtiver credibilidade com base na santidade de regras e poderes tradicionais" (Ibidem: 226). Exemplo premente deste caso, para Weber, é a autoridade patriarcal doméstica, identificada, por exemplo, no Mediterrâneo romano (Ibidem: 377), uma vez que a autoridade tradicional possui certa fundamentação em relações pessoais relativamente estreitas, como entre os membros de uma família:

The person exercising authority is not a "superior," but a personal master, his administrative staff does not consist mainly of officials but of personal retainers, and the ruled are not "members" of an association hut are either his traditional "comrades" or his "subjects." Personal loyalty, not the official's impersonal duty, determines the relations of the administrative staff to the master. Obedience is owed not to enacted rules hut to the person who 
occupies a position of authority by tradition or who has been chosen for it by the traditional master. (Ibidem: 227)

Uma segunda forma de autoridade, para Weber, é a que ele chama "racionallegal". Para o autor, a autoridade racional-legal baseia-se na "crença na legalidade de normas promulgadas e no direito de proferir comandos daqueles que foram alçados ao posto de autoridade à luz das regras" (Ibidem: 215). Ela diferencia-se da autoridade tradicional pela intencionalidade das regras sociais, que tomam iniciativa consciente de estabelecer níveis de dominação entre pessoas, sem a necessidade do ontem eterno legitimador da tradição (Ibidem: 217). Em outras palavras, não só determinados atores sociais intentam estabelecer a forma de dominação, como os dominados conhecem e/ou reconhecem esse fato. Quando reconhecem, existe aí uma relação de autoridade.

A terceira forma de autoridade destacada por Weber é a que ele denomina "carismática", fundada na excepcionalidade do sujeito a partir da posse pelo mesmo de dons especiais que lhes são únicos. Nas palavras do autor, ela se baseia "na devoção à santidade excepcional, heroísmo, ou caráter exemplar de uma única pessoa, e dos padrões normativos de ordem revelados ou ordenados por ela" (Ibidem: 215). Diferentemente do caso da autoridade legal-racional, a carismática guarda semelhanças com a tradicional, podendo ambas por vezes serem confundidas em um mesmo indivíduo:

In this process the two basically antagonistic forces of charisma and tradition regularly merge with one another. This stands to reason, for their power does not derive from purposive-rational regulations and their observance, but from the belief in the sanctity of an individual's authority, which is unquestionably valid for the ruled (children, disciples, retainers or vassals), whether or not it really claims to be absolute. Both charisma and tradition rest on a sense of loyalty and obligation which always has a religious aura. (Ibidem: 1122)

As três formas de autoridade são tomadas por Weber como tipos puros, ou seja, dispostas abstratamente de forma separada, de modo a distingui-las. No fenômeno social, contudo, não é descartada a ideia de que mais de uma forma possa estar presente no mesmo indivíduo, por vezes mesmo as três de uma só vez. No caso acima citado, por exemplo, não ocorre apenas que as características de autoridade tradicional e carismática sejam confundidas, mas também que, por vezes, ambas as formas de exercício de 
autoridade se encontrem representadas em um mesmo indivíduo. Uma das características mais marcantes da autoridade carismática para Weber, porém (e que a distingue de todas as outras formas), é o sujeito de limitação dos poderes do líder: no caso da tradicional, existem limites igualmente estabelecidos pela tradição, e na racional-legal, pela lei criada pelos agentes sociais. No caso da carismática, porém, é o próprio líder que, no limite, tem o poder de limitar o seu próprio poder:

In radical contrast to bureaucratic organization, charisma knows no formal and regulated appointment or dismissal, no career, advancement or salary, no supervisory or appeals body, no local or purely technical jurisdiction, and no permanent institutions in the manner of bureaucratic agencies, which are independent of the incumbents and their personal charisma. Charisma is self-determined and sets its own limits. Its bearer seizes the task for which he is destined and demands that others obey and follow him by virtue of his mission. If those to whom he feels sent do not recognize him, his claim collapses; if they recognize it, he is their master as long as he "proves" himself. However, he does not derive his claims from the win of his followers, in the manner of an election; rather, it is their duty to recognize his charisma. (Ibidem: 1112-3)

Neste ponto, podemos passar para a segunda teórica à qual nos referimos, Claudia Rapp, que se dedicou a um estudo específico acerca do desenvolvimento do episcopado cristão, desde o século I até ao VI d.C., embora se foque consideravelmente mais sobre o período da Antiguidade Tardia. Em sua obra Holy Bishops in Late Antiquity: The Nature of Christian Leadership in an Age of Transition, Rapp apresenta três categorias de autoridade presents no cristianismo antigo e tardo-antigo que a ajudam a pensar o crescente destaque dado ao bispo no ambiente urbano mediterrânico do período: espiritual, ascética e pragmática (RAPP, 2005: 16-7).

A autoridade espiritual indica que o seu portador recebeu o $\pi v \varepsilon \tilde{\mu} \mu \alpha$, o Espírito de Deus. Sua fonte, portanto, é externa ao indivíduo, sendo o Espírito um dom conferido por Deus, sem que haja uma participação pessoal ou preparação por parte do recebedor anterior à sua eleição pela divindade. Justamente por conta de advir de uma fonte externa, a autoridade espiritual é autossuficiente, não precisando ser reconhecida por qualquer outro indivíduo para que exista. Rapp completa: "In highlighting the concept of spiritual authority, I follow the lead of the Christian writers of the later Roman Empire who acnowledged God as the source of all gifts of the spirit" (Ibidem: 16). 
A autoridade ascética engloba o reconhecimento, caro a Weber, das habilidades "carismáticas". Para Rapp, a autoridade ascética tem sua origem nos esforços pessoais do indivíduo por meio da submissão do corpo e da prática de um comportamento virtuoso. O esforço ascético dirige-se a um ideal de perfeição pessoal. Por esse motivo, diferentemente do caso da autoridade espiritual, a ascética é acessível a todos, precisando o indivíduo apenas se dispor a percorrer o caminho da ascese para ser alçado a uma posição especial de exercício de influência e mesmo dominação sobre outras pessoas. Por outro lado, tal autoridade, para se fazer valer, precisa ser visível e reconhecida por outros indivíduos, sobretudo por meio da exposição pessoal através da aparência, estilo de vida e conduta. Apesar das semelhanças claras com o ideal weberiano de autoridade carismática, Rapp evita uma conexão entre ambas:

I refrain from using the term "charismatic" in this context, because it has been given a very specific meaning in Weber's influential theory of charisma. Charisma, in his view, can exist only inasmuch as it is recognized by others and generates discipleship. It emerges through the interplay between the charismatic leader and his followers. Weber's notion of charismatic authority functions in specific contradistinction to institutionalized authority, dichotomization that this study hopes to transcend by introducing a model that embraces three types of authority: spiritual, ascetic, and pragmatic. (Ibidem: 17)

Por fim, Rapp destaca a autoridade pragmática, fundamentada nas ações de um indivíduo. Diferentemente do caso da ascética, aqui as ações não são voltadas para uma adequação a uma norma de conduta própria, mas para o benefício de outras pessoas. De princípio, o acesso a esse tipo de autoridade é restrito, uma vez que depende do posicionamento social do indivíduo, que deve lhe garantir os recursos para que possa fazer as boas ações que o destacam socialmente e lhe garantem a influência necessária para ser considerado uma autoridade. Por fim, tal forma de exercício de autoridade é sempre pública: "The recognition of pragmatic authority by others depends on the extent and success of the actions that are undertaken on their behalf" (Ibidem: 17).

Uma vez mais destacamos que o foco de Rapp é o episcopado cristão tardo-antigo, sobretudo aquele dos séculos IV e V d.C. Como estamos buscando fugir aos riscos anacrônicos de considerar o objeto de nossa pesquisa a autoridade de bispos da passagem dos séculos I e II d.C., devemos reconhecer que a aplicabilidade do modelo de Rapp no 
estudo é severamente comprometida de princípio. No entanto, o fato de a autora não restringir tais tipos de autoridade apenas aos bispos, mas, ao invés, visar apresentar uma narrativa onde os mesmos vão incorporando formas de autoridade anteriormente presentes em outros componentes das igrejas cristãs, cremos que a apresentação de seu aporte teórico possa servir para iluminar, quando da leitura dos capítulos ulteriores, as diferenças básicas entre, por exemplo, um homem que se afirmava supervisor de uma determinada comunidade cristã e outro que se definia como inspirado pelo Espírito de Deus.

No entanto, o estudo não se prende às formas discursivas de legitimação e concentração de autoridade em torno do supervisor cristão. Para além desse ponto, visamos apresentar as consequências práticas diretas do discurso inaciano em termos de controle social, sobretudo na construção ideal que ele faz do culto cristão em suas exortações. Ora, já Durkheim via no culto o elemento central do fenômeno religioso:

O culto não é simplesmente um sistema de signos pelos quais a fé se traduz exteriormente, é o conjunto dos meios pelos quais ela se cria e se recria periodicamente. Quer consista em manobras materiais ou em operações mentais, é sempre ele que é eficaz. (DURKHEIM, 1996: 460)

Certamente, não estamos aptos a afirmar, com Durkheim, que todo fenômeno religioso tenha no culto o seu ponto central, embora certamente iremos considerar tal ponto quanto ao caso do cristianismo asiático em seus primórdios. Mais importante, porém, para entender o posicionamento do sociólogo francês é a sua noção de que toda religião é necessariamente um fenômeno social e também originado da sociedade. Neste sentido, o culto possui importância crucial por ser o momento em que os fieis vivenciam o que aprendem do ambiente social no qual se encontram inseridos. Em outras palavras, o culto serve, sobretudo, como fator primordial de controle social:

A julgar pelas aparências, os ritos com frequência dão a impressão de operações puramente manuais - unções, lavagens, refeições. (...) Assim entendida, a técnica religiosa parece ser uma espécie de mecânica mística. Mas essas manobras materiais não são mais que o invólucro externo sob o qual se dissimulam operações mentais. No fundo, trata-se não de exercer uma espécie de coerção física sobre forças cegas e, aliás, imaginárias, mas de atingir consciências, tonificá-las, discipliná-las. (Ibidem: 463; grifo meu) 
A partir da reflexão de Durkheim, devemos fazer alguns adendos no caso de nosso estudo. Primeiramente, não é apenas nos gestos rituais que se encontram os meios pelos quais um grupo social pode disciplinar os indivíduos. O mesmo ocorre em outros fatores internos ao culto, como a disposição espacial daqueles que presidem ao mesmo com relação aos fieis comuns (a "laicidade" de Bourdieu e Torjensen), assim como a escolha do local destinado à reunião cultual e as restrições de outros possíveis candidatos. O controle social pode ser exercido de formas bem diretas no ambiente de culto. Em segundo lugar, Durkheim insiste muito no conceito de "sociedade" como perpetuadora das normas sociais por meio da religião. Ora, o que temos visto até aqui é que, se existe agrupamento social, muito provavelmente existem lideranças. E onde existem lideranças, existem formas de legitimação das mesmas, ou seja, autoridade. Se há autoridade, existem formas de exercício da mesma. Deste modo, devemos insistir muito no ponto de que existem indivíduos por trás da direção do culto e que o mesmo pode (e, usualmente, será utilizado) para firmar sua autoridade frente ao grupo reunido. Em suma, onde Durkheim vê uma sociedade disciplinando os fieis, nós optamos por refinar o olhar e procurar os indivíduos que possuem esse objetivo.

Ainda é necessário ressaltar um ponto referente aos conceitos utilizados na

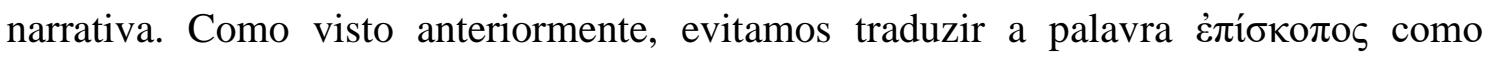
"bispo", mas também evitamos deixá-la sem tradução, e esta é sempre a tendência em toda a dissertação, inclusive quanto ao termo oĩ o $\zeta$, o qual traduzimos pelo conceito técnico household, advindo da antropologia. Não deixamos de fazê-lo, também, com o

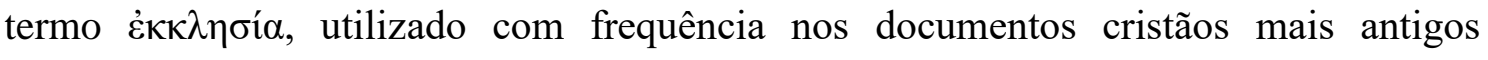
(inclusive de tendências cristãs bem diferentes) para referir-se ao conjunto do movimento, tanto a nível local quanto ao supralocal. Alguns estudiosos contemporâneos, como Destro e Pesce, preferem não traduzir o termo, uma vez que usar o termo "igreja" em seu lugar poderia soar anacrônico, já que "a ecclesia ( $\mathrm{sic}$ ) paulina muito pouco tem em comum com a igreja paroquial, com a igreja diocesana, com a igreja católica ou a protestante, ou a ortodoxa, ou a copta, ou a armênia, e assim por diante" (DESTRO e PESCE, 2010: 13). Embora as ressalvas de Destro e Pesce sejam muito concernentes, ainda assim preferimos fazer a tradução do termo por "igreja", mais por razões heurísticas do que por uma adequação perfeita do conceito. A razão para essa escolha é o fato de o termo possuir usos ao mesmo tempo comuns e diversos na documentação: enquanto todas as fontes concordam em usá-lo como designação de um grupo social composto por cristãos 
batizados, a especificidade de sua aplicação varia conforme o caso e o interesse do autor. Deste modo, Dale B. Martin nota que, para Paulo, o termo certamente traria automaticamente a ideia mais literal de uma "assembleia", conforme o modelo daquelas que reuniam os cidadãos de uma cidade grega, ao passo que o autor de 1Timóteo não vê nenhum pudor em usar o mesmo conceito para referir-se ao que ele considera como "household de Deus" (B. MARTIN, 2012: 289). Assim, optamos pelo uso do termo "igreja", embora reconhecendo não ser a melhor forma de expressar o conceito e advertindo para os perigos do anacronismo em sua leitura, conforme Destro e Pesce: a

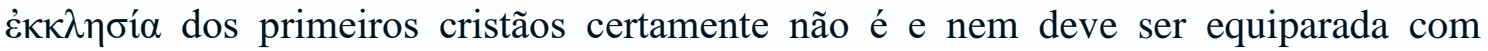
qualquer forma de igreja desenvolvida nos séculos posteriores.

Por outro lado, a pesquisa não visa ressaltar a todo tempo a diversidade do cristianismo antigo, apresentando os diversos grupos cristãos contando com sua própria doutrina e prática ritual (muitos deles hipotéticos). Ao invés, ela é um pressuposto de todo trabalho, inclusive apontando para os riscos de uma leitura sociológica que crie grupos muito rígidos onde poderia existir uma maior diversidade. Aqui, podemos nos manter no ponto de vista expressado por Pedro L. Vasconcellos e Pedro Paulo Funari sobre Paulo de Tarso:

Consideramos que as sociedades são caracterizadas pela diversidade e que as pessoas vivem em constante mudança. Isso significa que, no que se refere ao mundo na época de Paulo, não havia uma única maneira de pensar ou de agir. (VASCONCELLOS e FUNARI, 2013: 6-7)

Ao mesmo tempo, não estamos aptos, por conta da limitação da documentação, a ter uma visão clara de até que ponto aqueles cristãos que são hoje colocados pela historiografia em grupos apartados, se reconheciam ou não como membros de um mesmo movimento, ao menos em um período tão antigo quanto a segunda metade do século I e o começo do século II d.C. Inácio de Antioquia, por exemplo, estava claramente empenhado em desqualificar certos cristãos, negando-lhe parte no grupo ao qual ele mesmo fazia parte, mas não sabemos até que ponto a recíproca era mesma, se era. De qualquer modo, como tudo é muito nebuloso e a diversidade é tomada aqui como regra, sempre que o termo "cristianismo" aparecer no texto, ele deve ser lido de forma mais próxima a um coletivo singular, onde cristianismos diversos certamente possuem pelo menos alguns elementos comuns, nem que seja a mera crença em Jesus de Nazaré como 
um Cristo Salvador, mesmo que a natureza desta salvação seja um ponto de grande discórdia entre as várias tendências.

A presente dissertação se pretende um estudo de História Social, investigando um fenômeno social específico que é o desenvolvimento de uma forma de liderança interna às primeiras comunidades cristãs. Propomos que o dito fenômeno social só pode ser entendido à luz da conjuntura histórica específica do Império Romano do século I e começo do II d.C., ao mesmo tempo que também consideramos necessário levar em conta estruturas sócio-econômicas próprias do Mediterrâneo antigo, especialmente em sua fatia oriental. Certamente a dissertação não pretende ser um trabalho quantitativo ou um estudo que abrange uma longa duração; na verdade, o capítulo principal do estudo se volta, sobretudo, a um acontecimento específico, a saber, a escrita das sete cartas por Inácio de Antioquia quando de sua viagem como condenado a Roma, pousando um tempo considerável na província romana da Ásia Proconsular. No entanto, o conteúdo das cartas de Inácio apresenta elementos que só podem ser satisfatoriamente entendidos tendo-se em vista o ambiente social na qual ele se encontrava agindo, com suas estruturas inerentes. Esse ponto, porém, não elimina a capacidade de ação do indivíduo Inácio de Antioquia e sua solução criativa para uma maior aceitação e efetividade da autoridade do supervisor cristão, mas mostra sua capacidade de manobra frente às circunstâncias nas quais se encontrava, e aos fatores sociais dos quais as comunidades às quais se dirigia não poderiam fugir. Ao invés, ao tratar do caso do desenvolvimento da autoridade do supervisor cristão na Ásia e da ação de Inácio nesse sentido, esperamos contribuir para estudos mais abrangentes que, esses sim, tenham escopos mais abrangentes, como a história da liderança no cristianismo em geral, ou uma análise de maior fôlego sobre as diversas formas de organização do culto privado no mundo antigo. Neste sentido, guiamonos pelas palavras de Albert Soboul: "É do âmbito da história social tudo o que diz respeito às relações profissionais, à formação dos espíritos e das consciências, à sensibilidade colectiva, numa palavra, tudo o que pertence à psicologia social" (SOBOUL, 1973: 40).

Ao optarmos pela História Social, porém, nos defrontamos com a dificuldade que é o caráter limitado das fontes: o cristianismo asiático mais antigo simplesmente não produziu documentação diversificada e numerosa, de modo que dele temos unicamente 
um conjunto de obras literárias que podem ser usadas na análise. Como confrontar tal problema? O estudioso francês do cristianismo antigo, Jean Daniélou, demonstrou ser possível utilizar a macroanálise (ele não usa o termo, mas flerta com o conceito) por meio de uma inserção do objeto analisado em seu contexto geral e regional. Afinal, segundo ele, se um estudioso resolvesse se voltar, por exemplo, para o estudo do primeiro grupo cristão em Jerusalém, fundamentando-se unicamente nos "acontecimentos seguramente estabelecidos", haveria um trabalho final como resultado, mas consideravelmente parcial (DANIÉLOU, 1968: 25). A solução para Daniélou, no caso de seu estudo, é a inserção da primeira comunidade no que ele chama de "fundo panorâmico judeu" (Ibidem: 26) do qual fazia parte. Deste modo, tendo um plano maior como contextualização, é possível procurar fenômenos sociais a ele inerentes que possuam pontos de contato com o objeto estudado.

A macroanálise, portanto, surge como um meio fundamental de levarmos o estudo à frente. Desse ponto de vista, Inácio de Antioquia aparece como um personagem histórico singular. Não morre em silêncio, mas escreve cartas, defende a unidade cristã em torno do supervisor, mas sempre nos limites do seu tempo e das comunidades às quais se dirige. Braudel o consideraria um grande homem de ação, conforme a sua definição: “...aquele que avalia exatamente a estreiteza das suas possibilidades, que escolhe manterse aí e aproveitar o peso do inevitável para o acrescentar ao seu próprio avanço" (BRAUDEL, 1995: 624). É, ao mesmo tempo, um homem que deixou pouquíssima obra para a posteridade. Com sorte, dele possuímos documentos que são, pelo seu gênero, ao mesmo tempo de caráter marcadamente pessoal, ao mesmo que tempo que expressivos e comunicativos de suas ideias; representativos, em suma, de sua agenda. Considerando a limitação documental própria ao cristianismo do período estudado, não há outro caminho a não ser utilizarmos, também, da microhistória. Sobre esse tipo de trabalho histórico, escreveu Ginzburg: "Se a realidade é opaca, existem zonas privilegiadas - sinais, indícios - que permitem decifrá-la" (GINZBURG, 2003: 177). Neste sentido, convém considerar a contribuição que pode ser dada pelos trabalhos exegéticos, como no caso do extenso comentário de William R. Schoedel, já citado anteriormente. A importância da exegese para a análise dos textos cristãos antigos é perfeitamente colocada por Destro e Pesce:

A exegese é a base essencial da análise. Os teóricos da exegese histórica sempre sustentaram que o sentido de um texto é aquele que o autor pretendeu e que o destinatário de seu tempo tinha a capacidade de compreender. Essa 
teoria tem o grande mérito de afirmar que um texto adquire significado dentro do contexto geral de uma cultura historicamente determinada. Assim, a exegese tem a função de reconstruir os significados históricos das palavras e dos conceitos usados nos textos. (DESTRO, 2010: 6)

Um referencial brasileiro para uma análise fundamentada, ao mesmo tempo, na macrohistória e na microhistória, é Emília Viotti da Costa, que sugeriu essa estratégia em seu clássico Coroas de glória, lágrimas de sangue:

Procurei unir, nessa abordagem, a macro e a micro-história. Minha decisão nasceu da convicção de que é impossível compreender uma sem a outra. Mas nem a história é o resultado de uma 'ação humana' misteriosa e transcendental, como querem uns, nem os homens e as mulheres são fantoches de 'forças' históricas, como querem outros. (COSTA, 1998: 19)

A dissertação encontra-se dividida em três capítulos. O primeiro é dedicado a uma contextualização geral e local, tendo em vista a necessidade de apontar a conjuntura histórica na qual se dá o desenvolvimento das formas de liderança e de relação de autoridade no cristianismo da Ásia Proconsular. Do mesmo modo, estruturas sociais e econômicas do Mediterrâneo são levadas em conta. Ao longo do capítulo, buscamos oferecer um panorama geral, respectivamente, do Mediterrâneo romano como um todo, da província da Ásia em particular, e das formas de manifestação religiosa existentes na região citada, sobretudo em suas cidades de maior destaque no plano político, econômico e cultural.

O segundo capítulo possui um caráter marcadamente conjuntural. Nele, abordamos o cristianismo conforme ele se desenvolveu na província asiática anterior à passagem de Inácio de Antioquia como prisioneiro escoltado. Para tanto, fazemos, inicialmente, um balanço e escolha pormenorizados das fontes a ser utilizadas ao longo do capítulo, um ponto fundamental para toda a análise. A partir daí, voltamo-nos para uma narrativa da expansão do cristianismo na região no século I d.C., primeiramente no plano geográfico e, posteriormente, no social, com o balanço dos estratos sociais que comporiam os grupos cristãos, assim como dos conflitos que tal composição poderia engendrar. Em seguida, voltamo-nos para uma descrição do culto cristão na região e de 
suas funções sociais para a integração do grupo. Por fim, a última e mais importante parte do capítulo se destina a discussão das formas de exercício de autoridade existentes nas comunidades cristãs asiáticas no período, assim como o desenvolvimento histórico das mesmas e as relações entre si.

Por fim, o terceiro capítulo tem, como foco, o personagem histórico Inácio de Antioquia e suas cartas. Antes de tudo, discutimos questões críticas referentes à documentação, como quais cartas foram recebidas e o debate em torno de sua autenticidade. Em segundo lugar, visamos retirar da documentação o máximo de informações possível acerca de Inácio e de sua trajetória, de modo a termos um perfil mínimo (ainda que opaco) de nossa fonte. Por fim, partimos para a análise da documentação em si, analisando, primeiramente, como o autor constrói retoricamente para si um manto de legitimação, de modo que sua mensagem possa ter um efeito singular sobre os seus destinatários, e, posteriormente, quais as estratégias existentes em seu discurso de modo a alçar o supervisor cristão a um novo patamar de autoridade nas comunidades cristãs da Ásia, tendo em vista a unidade (conforme uma concepção própria inaciana) do grupo. 


\section{Capítulo 1 - Ambientação geral: o cristianismo asiático antigo em seu contexto social, político e econômico}

Todo fenômeno histórico só pode ser analisado de forma coerentemente científica quando inserido em seu contexto sócio-político-econômico. A História é a disciplina que analisa e trabalha com os homens em seu tempo, seguindo a formulação de Marc Bloch em sua Apologia da História ou o ofício de historiador (BLOCH, 2002: 55). "Homens" no plural, como lembra também o mesmo mestre, pois "mais que o singular, favorável à abstração, o plural, que é o modo gramatical da relatividade, convém a uma ciência da diversidade" (Ibidem: 54). Com o cristianismo antigo, não ocorre de forma diferente: trata-se de um fenômeno histórico gerado por homens, levado à frente por homens, afetando homens. Homens e mulheres, para não nos mantermos circunscritos à injustiça da generalização tradicional. De qualquer modo, cumpre antes de tudo fazermos uma leitura crítica do fenômeno histórico que é não apenas a difusão do cristianismo em uma região específica do Império Romano, a saber, a província da Ásia Proconsular, mas, sobretudo, e especificamente em nosso estudo, o desenvolvimento de uma função interna

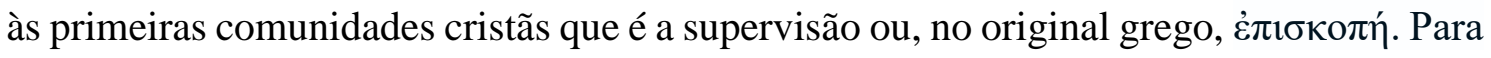
tanto, é necessário se apresentar o contexto sócio-político-econômico no qual se dá tal fenômeno, não porque seja um simples palco no qual se desenrola a ação dos agentes históricos, mas por ser o ambiente no qual a mesma acontece. O ambiente não é ignorável, pois influi, e muito, nos processos sociais.

De fato, como expressou Hans-Josef Klauck, “o Império Romano constitui o mais abrangente contexto político, social e econômico para a emergência do cristianismo primitivo" (KLAUCK, 2006: 69). Isso significa que todos os personagens do processo histórico que é a difusão e organização do cristianismo em seu primeiro século de existência (isto é, mais ou menos entre 30 e 130 d.C. ${ }^{1}$ ) estavam inseridos neste caldo social que era o conjunto das comunidades urbanas e rurais altamente conectadas e integradas que constituíam o Mediterrâneo romano. Mais especificamente, estamos

\footnotetext{
${ }^{1}$ Em termos históricos, soa um tanto inverossímil traçar o início do cristianismo na própria atividade de Jesus de Nazaré, uma vez que tão pouco se sabe a respeito de seus pensamentos e seus projetos para a comunidade religiosa que visava fundar (isto se visava realmente fundar alguma). Deste modo, seria arriscado tratar o grupo religioso constituído por Jesus e seus discípulos mais próximos como "cristão", inclusive devido à atestação feita pelos próprios Atos dos Apóstolos de que mesmo esse modo de referirse àqueles que aderiam ao movimento levado à frente pelos discípulos de Jesus teria sua origem posterior à morte do mesmo, em Antioquia da Síria (cf. Atos 11,26). Por conta disso, alguns estudiosos preferem adotar outras formas de se referir ao grupo dirigido pelo mestre nazareno, como "movimento de Jesus", utilizado por Destro e Pesce (cf. p. ex. DESTRO E PESCE, 2010: p. 96).
} 
tratando aqui do Império Romano do século I e das primeiras décadas do século II d.C., pois, por mais que existam muitas estruturas sociais e econômicas que permanecem praticamente incólumes durante todo o período antigo e mesmo pelo tardo-antigo (isto é, até pelos séculos VI e VII d.C.), é necessário resguardar o presente estudo do perigo da generalização total, abrangendo fenômenos históricos que estão longe de se manterem estáticos durante todo esse período, como ocorre no próprio caso do cristianismo.

O primeiro capítulo, portanto, objetiva traçar uma narrativa contextualizante que permita à análise posterior estar munida de informações suficientes para compreender o processo social que é o foco próprio da pesquisa, a saber, a centralização e concentração da função de supervisão da comunidade cristã em um único indivíduo, assim como para inserir a fonte sobre a qual nos debruçaremos em seu ambiente próprio. Para tanto, se buscará, primeiramente, traçar um quadro breve e geral, a partir da historiografia, acerca da organização política e social do Império Romano, com especial destaque para a relação entre capital e províncias. Em seguida, também a partir da historiografia, será feita uma narrativa sumária acerca da província da Ásia Proconsular, com especial enfoque cronológico no século I d.C. e primeira metade do século II d.C. Por fim, será necessário desenhar um quadro referente às diversas formas de organização e vivência religiosa nas cidades da província estudada.

\section{1: O Mediterrâneo sob o jugo romano}

O personagem histórico que produziu a documentação que serve de base para nosso estudo, Inácio de Antioquia, era um homem que vivia em um mundo altamente conectado, desde sua (possível) terra natal, a Síria, até os pilares de Hércules, no encontro entre o Mediterrâneo e o oceano Atlântico. Deste modo, quando é preso e despachado para Roma (em condições que, como veremos no capítulo 3, estão longe de estarem esclarecidas) em uma viagem feita sobretudo por terra ${ }^{2}$, já tem em vista sua imolação final na arena da capital, de modo a servir de entretenimento à sua população. Em nenhum momento prevê dificuldades que possam afetar seriamente o percurso que deveria ser percorrido desde a Síria até a Itália, na companhia de um destacamento de soldados ${ }^{3}$. Não

\footnotetext{
${ }^{2} \mathrm{O}$ possível itinerário seguido pelos soldados responsáveis por conduzir Inácio de Antioquia até a capital imperial será tratado também no capítulo 3.

${ }^{3}$ Cf. In.Romanos 5,1: "Luto com feras selvagens da Síria a Roma, por terra e mar, dia e noite, acorrentado a dez leopardos - isto é, uma companhia de soldados - os quais se tornam piores quando bem tratados" (Trad.: SCHOEDEL, 1985: 178).
} 
existem terras inimigas de Roma que possam vir a bloquear o caminho, nem existem fronteiras territoriais a serem atravessadas. Ao contrário, não só o autor das sete cartas inacianas não vê grandes complicações no caminho, tanto no já percorrido (da Síria à Ásia, na costa oeste da Ásia Menor) quanto no ainda por percorrer, como espera que as comunidades cristãs das cidades de Filadélfia e Esmirna, importantes centros urbanos da província da Ásia, enviem representantes para fazer o caminho contrário e ir até a Síria transmitir suas felicitações à igreja de Antioquia, a metrópole regional (cf. In.Filadelfienses 10; In.Esmirniotas 11). O nível de conexão entre as regiões e polos habitacionais do Mediterrâneo discernível por meio das cartas do supervisor cristão sírio sugere uma realidade política, econômica e social notável, mesmo para os olhares modernos: politicamente, nota-se o dispendioso transporte de um homem feito prisioneiro pelo aparato estatal romano de uma ponta do mar ao centro da Itália; economicamente, a aparente e relativa facilidade com que ocorre a viagem no mínimo sugere que algo semelhante poderia ser feito por aqueles que tinham no comércio inter-regional sua profissão, mesmo considerando a possibilidade de os soldados encarregados de transportar Inácio estarem utilizando o cursus publicus, em geral reservado ao exército e aos agentes do Estado; socialmente, o fato de Inácio meramente se atrever a pedir a seus destinatários que fizessem o percurso contrário (desta vez, às suas próprias custas!) aponta para uma possível mobilidade social, ao menos geográfica: existiam meios para uma pessoa se deslocar de um ponto distante a outro do mar. Poderíamos mesmo nos arriscarmos a anotar um detalhe no campo cultural, a saber, a raiz latina do nome de um habitante da Síria.

Como veio o Mediterrâneo a se tornar uma região tão conectada em si, sob o comando de um único poder político-militar? Que império é esse responsável por prender Inácio de Antioquia, garantir a infraestrutura para que fosse devidamente transportado e, ao mesmo tempo (e possivelmente sem querer), para que sua fé fosse difundida, fortalecida e organizada? Grande estudioso do cristianismo mais antigo, Klauck vê dois principais desenvolvimentos para a situação que encontramos no Mediterrâneo do primeiro século de existência do novo movimento:

O primeiro, iniciando talvez em 229-228 AEC com a primeira guerra ilíria, é a conquista sucessiva da parte oriental do mundo mediterrâneo pelos romanos, que foram capazes de capitalizar sobre a propagação do helenismo para toda a Ásia Menor, Pérsia e Egito no despertar de Alexandre e de seus 
sucessores, os Diadochoi. Então, na segunda metade do primeiro século AEC, a república romana foi transformada em algo novo, retendo o nome de república, mas na verdade agora uma autocracia de um homem, que depois tomou para si o título homônimo Caesar (Kaisar em grego). (KLAUCK, 2006: 69; tradução própria)

Os dois pontos levantados por Klauck são dignos de destaque e, a partir da discussão e questionamento dos mesmos, poderemos estabelecer o ambiente no qual se dão os acontecimentos e os processos que são foco desta dissertação. De fato, a integração política e econômica do Mediterrâneo é essencial para se compreender a rápida difusão da fé dos seguidores de Jesus pela porção oriental do mar e o caráter destacado de comunidades presentes em determinados centros urbanos, como no caso de Éfeso na costa oeste da Ásia Menor e de Antioquia na Síria.

De início, é necessário anotar que Klauck indica desenvolvimentos que são de fato essenciais para se compreender o Mediterrâneo dos séculos I e II d.C., especialmente em sua porção oriental, onde o comércio e as trocas eram intensos no mar Egeu (que banhava os portos de cidades importantes para o presente estudo, como Éfeso e Esmirna) e nas margens mais a leste do mar, a saber, a porção costeira sul da Ásia Menor, a SíriaPalestina, assim como na costa do Egito, com sua grande metrópole, Alexandria, provavelmente a segunda maior em número de habitantes em todo o império ${ }^{4}$. Tais desenvolvimentos são basicamente, em primeiro lugar, o processo de integração política e econômica da porção oriental do mar, e, em segundo lugar, o papel executado pela nova organização do poder em Roma (e, consequentemente, em todas as regiões do mar que se encontravam sob sua influência ou dominação direta) na manutenção dessa ordem de coisas sob sua chancela.

No entanto, a caracterização que faz Klauck desses dois desenvolvimentos pode ser questionada em alguns pontos essenciais. No seguimento das próximas subseções, não se pretende entrar em um debate historiográfico com Klauck, considerando-se que a caracterização do mundo greco-romano não é o foco de sua obra maior (embora seja o de seu capítulo citado, produzido para o primeiro volume da Cambridge History of Christianity). Busca-se, ao invés, utilizar o texto do estudioso alemão como representação paradigmática de certas concepções contextuais acerca do ambiente maior no qual se

\footnotetext{
${ }^{4}$ É possível que Alexandria já contasse com uma população de cerca de 600.000 habitantes no século I; cf. HARRIS, 2000: 712. Gleason afirma que a metrópole egípcia teria "metade do tamanho de Roma, com uma população em seu ponto máximo de cerca de meio milhão" (GLEASON, 2006: 231).
} 
desenvolve o cristianismo antigo que são ligeiramente comuns nos trabalhos em torno do tema ${ }^{5}$. Objetiva-se, em suma, enriquecer o presente trabalho com os estudos e reflexões dos historiadores e classicistas que se voltam para o estudo do Mediterrâneo Antigo, em suas respectivas especificidades e enfoques temáticos, geográficos e cronológicos.

\subsection{1: Império Romano e integração no Mediterrâneo}

Abordemos, antes de tudo, o primeiro desenvolvimento destacado pelo estudioso. Nesse ponto, é dito que os romanos capitalizaram sobre a expansão do helenismo pelas regiões orientais, com o papel essencial executado por Alexandre, rei da Macedônia, e por seus sucessores à frente dos vários reinos fundados às margens do Mediterrâneo oriental, cujas fronteiras encontravam-se em constante alteração em consequência das várias guerras levadas a cabo entre si. No entanto, certo é que os romanos capitalizaram sobre bem mais do que apenas a expansão da cultura grega a partir de Alexandre e dos Diádocos. Um mar Mediterrâneo integrado não foi obra somente de um império que se aproveitava da difusão precedente (e, por vezes, imposição) de paradigmas culturais helênicos. Foi, antes, um longo processo que envolveu inclusive o estabelecimento de contatos entre as sociedades que se agrupavam em torno de um mesmo macroespaço, contatos esses certamente envolvendo trocas culturais, mas também (e destacadamente) comerciais. Em outras palavras, "o Império Romano, que durou séculos, apenas foi possível sob a base dos séculos de integração e consolidação de estruturas que o antecederam" (GUARINELLO, 2013: 139).

Um dos primeiros passos necessários, portanto, para se ensejar um estudo sobre um fenômeno distintamente mediterrânico, como no caso do cristianismo antigo, é abandonar uma determinada visão historiográfica que impõe um “excepcionalismo grecoromano" (PURCELL, 2014: 60) em termos de conexão e integração. A esse respeito, o diagnóstico de Nicholas Purcell mostra-se mais atual do que poderia ser considerado a princípio:

\footnotetext{
${ }^{5}$ Veja-se, por exemplo, o caso de W. H. C. Frend, em The Early Church, no qual aparenta manter uma visão muito semelhante à de Klauck, iniciando seu capítulo acerca da integração do Mediterrâneo em 27 a.C., com a vitória de Augusto sobre Marco Antônio e o fechamento, também por Augusto, das portas do templo de Jano, em Roma (FREND, 1965: 4-5). Logo à frente, Frend também faz a seguinte afirmação, também muito semelhante à de Klauck: "In theory, Octavian was only the chief citizen of the Republic; in practice, we was its absolute ruler" (Ibidem: 5).
} 
Far from calling the traditional constructions of ancient history into question, the study of the Mediterranean stands accused of reasserting a misleading prominence of Greek and Roman civilization which has constantly been burdened with political and ideological meanings. (Ibidem, pp. 59-60) ${ }^{6}$

Purcell nota bem o perigo de o historiador embarcar (mesmo que inconscientemente) em um pressuposto ideológico eurocêntrico ao adotar uma visão de que a escala de integração do Mediterrâneo quando do surgimento do cristianismo seria basicamente um produto da ação de gregos e romanos. Não se trata de negar a particularidade do período histórico específico sobre o qual nos debruçamos; afinal, pela primeira e única vez, o Mediterrâneo encontrava-se sob o domínio de um único poder, de uma única pólis. Objetivamos, ao invés, fugir de uma sutil armadilha ideológica, a saber, o excepcionalismo greco-romano (de raiz eurocêntrica) congregado à superestimação de um inevitável e predestinado universalismo cristão (também de claras raízes eurocêntricas e com um papel histórico conhecido no desenvolvimento do imperialismo europeu). Propomos, ao invés, um outro ponto de vista, do qual possamos partir para reconstruir o ambiente no qual se desenvolve o cristianismo antigo asiático: os contatos intensos entre agrupamentos humanos que tinham acesso ao mar Mediterrâneo, e que frequentemente dependiam dele para sua subsistência e sobrevivência, já possuíam um longo histórico quando o poder de uma pólis específica, Roma, se dispôs a garantir sua manutenção por meio de seu poderio militar e de sua eficiente política de administração desse vasto território.

\subsection{2: Reorganização do poder em Roma}

Nesse ponto, somos encaminhados ao segundo desenvolvimento citado por Klauck: a transformação da república romana em império romano. O estudioso caracteriza a nova forma de distribuição do poder (ou, melhor dizendo, de concentração do poder) como "autocracia", com a imposição do poder de um homem, o Caesar. Esse é o sistema que é correntemente chamado pela historiografia de "principado", considerado mais fiel à conjuntura do início do Alto Império, quando aquele que hoje chamamos de "imperador" executava a função de princeps, o primeiro dentre os

\footnotetext{
6 "The residual dangers of a revived Greco-Roman exceptionalism are outweighed by the promise of such longue-dureé analysis, while the abundant new evidence also helps remedy any lingering partiality for Greek or Roman history" (PURCELL, 2014: 60).
} 
senadores da república romana. No entanto, o termo "autocracia" pode levar a algumas incoerências, como imaginar um sistema no qual uma concentração absoluta de poderes em torno do imperador e de sua casa poderia acarretar, em consequência, uma anulação do papel e autonomia da administração local, nativa.

Certamente essa seria uma visão equivocada do fenômeno histórico-político conhecido como "principado". De fato, os acadêmicos que se dedicam a estudar os primeiros dois séculos do Império Romano (o que poderíamos um tanto grosseiramente chamar de "Alto Império", com alguma diferença de décadas) têm destacado o reduzido aparato administrativo romano, tendo em vista a extensão do território a ser governado e submetido. Clifford Ando, por exemplo, pondera que, nos dois primeiros séculos depois de Cristo (ou seja, quase exatamente o período que concerne este estudo), o governo central do império despacharia, em um dado ano, "cerca de 160 oficiais de elite para governar seus 55 milhões de súditos" (ANDO, 2006: 179) ${ }^{7}$. Ao contrário de uma autocracia, o que tem surgido das pesquisas de romanistas é um amplo sistema de aliança conservadora entre o poder central por um lado, ou seja, o princeps e seus administradores mais próximos, e as elites locais por outro, executando sua função secular de governo das pólis. Essa aliança, e mesmo o governo do Império como um todo pelo princeps, fundamentava-se sobretudo nas relações patrono-cliente, uma vez que "a posição do imperador foi baseada em laços patronais com seus adeptos, pois sob Augusto a competição política foi esterilizada e regulada através de um amplo sistema de patronato, encabeçado pelo Imperator" (MENDES, 2006: 39) ${ }^{8}$. Deste modo, Werner Eck caracteriza da seguinte forma o trabalho dos governadores, representantes do poder central:

As is suggested by the largely similar staffing of provinces, it was more important that the governors provide a clear representation of the power and

\footnotetext{
${ }^{7}$ Segundo Ando, os ditos oficiais de elite poderiam ser divididos "grosseiramente": “... holders of imperium ("right of command"), formally, at least, properly elected magistrates exercising power within an assigned domain; and supervisors of the government's finances" (ANDO, 2006: 179). A respeito da administração das províncias, ver também GARNSEY, 1987: 20-40.

8 “A auctoritas do príncipe era sustentada pelas mesmas noções que regulavam as relações entre patrono e cliente. De início era entendida como um processo, ou seja, o desempenho de uma perpétua liderança militar, uma ação contínua como o maior benfeitor da Res publica, não somente pela demonstração das suas virtudes (prudência, justiça, sabedoria, clemência, pietas, gravitas), pelas suas ações e realizações (meritiis), como também por ser o mais rico. O benefício gerado pelo imperador criava um débito (officium), o qual deveria ser reparado pela gratidão ( gratia). A relação de troca entre o imperador e seus súditos podia dificilmente ser em termos iguais, em decorrência da disparidade de recursos e poderes. (...) Por meritum a superioridade do Imperator é inquestionável. Os súditos devem, portanto, demonstrar sua gratia pela lealdade e pelo reconhecimento de sua posição inferior." (MENDES, 2006: 40). Tudo o que foi colocado por Mendes é aplicável às províncias, especialmente às suas elites.
} 
dominance of Rome, carry out their cult duties towards the provincials and the army units stationed in the province, and that they were accessible when needed by the inhabitants of the province. The everyday point of reference for provincials was and remained their own home community, within which and through whose officials and resources the public needs could normally be satisfied. Only when individuals or whole groups in the city thought that something here was not satisfactory would the governor be brought in to investigate. (ECK, 2000: 275) $)^{9}$

Em outras palavras, a unilateralidade de um sistema "autocrata" deve ser suavizada em vista de relações de poder mais marcadas por uma talvez pseudobilateralidade ${ }^{10}$. "Pseudo" porque, apesar de o poder romano ser, em geral, do interesse das elites locais na conservação (e mesmo alteração por meio de ascensão) de sua posição social, certo é que o poderio militar dos dominadores servia como uma perpétua e silenciosa advertência contra qualquer subversão da ordem. Deste modo, Plutarco podia dizer que o papel das elites locais era manter a paz e a ordem de suas circunscrições, lembrando que o coturno romano permanecia sempre sobre suas cabeças (Prescrições sobre política 17) ${ }^{11}$. Quando a subversão ocorria, como no caso da Primeira Guerra Judaica, o castigo era exemplar. Assim, o império poderia ser considerado uma aliança entre cidades ${ }^{12}$, mas uma aliança que era melhor não ser quebrada, para o bem do agrupamento social em questão.

\footnotetext{
${ }^{9}$ A esse respeito, diz Ando: "A number of scholarly trends have converged in recente years, urging us to view Roman government as minimalist in both its aims and achievement. Essentially reactive, it possessed neither the interest nor the ability to formulate policy, particularly concerning processes as complex as urbanization or acculturation" (ANDO, 2006: 192).

${ }^{10}$ Mais conveniente que o termo "autocrata" talvez seja a caracterização feita por Norma Musco Mendes acerca do regime do Principado: "As necessidades de gerir as novas condições sociais, econômicas, militares e administrativas surgidas pela criação do Império exigiram o desenvolvimento de um regime político de caráter pessoal, porém sob uma máscara republicana. Foi a estruturação do modelo romano de poder pessoal, podendo ser chamado de "monarquia republicana"' (MENDES, 2006: 27; ênfases minhas). Note-se que um regime "de caráter pessoal" não é necessariamente uma "autocracia".

${ }^{11}$ Henri-Louis Feroux destaca, por exemplo, a continuidade, sob o domínio romano, da competência das cidades da província da Ásia em designar magistrados (como no caso dos irenarcas) e representantes dos poderes cívicos (ou seja, elites urbanas) nas regiões rurais sob a jurisdição das respectivas pólis, assim como as funções dos mesmos variavam conforme a cidade à qual serviam, sendo adaptadas às situações locais: "Il est intéressant de noter combien la législation romaine et les cités envisagèrent de manière dissemblable l'institution de l'irenarchie. Alors que la première en avait une vision normative, certaines cités l'adaptèrent de manière très empirique à leur propre situation: magistrature aux compétences très larges, étendues à l'ensemble de la chôra civique dans certains cas, elle fut multipliée, dans d'autres cités, pour devenir une fonction aux compétences beaucoup plus étroites, limitées à des districts territoriaux comme à Termessos" (FERROUX, 2009: 157).

${ }^{12}$ Dentre os estudiosos do cristianismo antigo que adotaram a visão de que o Império Romano consistiria em uma aliança entre centros urbanos em torno do Mediterrâneo, podemos citar o influente Helmut Koester: "As cidades eram a espinha dorsal política e econômica do império romano (sic). Poder-se-ia até definir o império como uma liga de cidades, com Roma ao centro" (KOESTER, 2012: 335).
} 
Para o presente estudo, porém, não basta apenas afirmar categoricamente que a manutenção da ordem no império fundamentava-se sobretudo em uma aliança entre o príncipe e as elites locais. Alguns de seus elementos constituintes (os principais, talvez) devem ser destacados, pela importância que têm na posterior contextualização local a ser feita e na compreensão de alguns fatores internos ao cristianismo em seu primeiro século, especialmente naquelas comunidades localizadas em centros urbanos às margens do mar Egeu ou a ele conectados. Sugeriremos aqui quatro elementos.

\subsubsection{1: Cidadania romana}

Antes do edito de Caracala em 212, nem todo habitante do Império Romano era considerado um cidadão romano. Ao invés, excetuando os habitantes de Roma cujas raízes familiares estivessem arraigadas na $U r b s$, os cidadãos da Itália e das colônias romanas espalhadas pelo Mediterrâneo, apenas um número deveras restrito conseguia acesso a esta categoria social, que poderia, assim, ser encarada como uma espécie de distinção, ainda que, durante todo o Alto Império, os imperadores integrassem cada vez mais membros a esse grupo (GALSTERER, 2000: 358). Isso especialmente pelo fato de uma série de direitos serem reservados àquele que fosse reconhecido cidadão de Roma.

Um caso famoso de recurso à cidadania romana para o reclame dos privilégios a ela inerentes é o do apóstolo Paulo, segundo a representação feita pelos Atos dos Apóstolos ${ }^{13}$. Por duas vezes ele se vê estimulado a sacar sua distinção jurídica de modo a pressionar seus agressores. A primeira vez se dá em Filipos, na Macedônia, então uma

\footnotetext{
13 A factualidade da cidadania romana de Paulo reclamada pelos Atos dos Apóstolos é debatida entre os estudiosos. Jerome Murphy-O’Connor a defende, considerando-a consequência da cidadania romana conferida aos principais líderes de Tarso. Em sua teoria, "os pais de Paulo teriam sido comprados por um cidadão romano de Tarso; quando foram libertados, teriam recebido legalmente essa cidadania de seu patrão" (MURPHY-O’CONNOR, 2013: 26). Já Helmut Koester lança uma série de dúvidas sobre a alegada cidadania romana de Paulo (KOESTER, 2012: 114-5). Em primeiro lugar ele questiona a própria origem do apóstolo em Tarso, citada unicamente pelos Atos dos Apóstolos dentre os documentos cristãos do século I d.C. (se ele era um artesão tarsense, por que encontrava-se aparentemente instalado em Damasco quando "foi chamado"?) Em segundo lugar (e aqui ele faz um questionamento certeiro), como explicar que um cidadão romano receba tantas punições quanto as listadas por Paulo em 2Coríntios 11,24ss? Ainda considerando que casos como o relatado pelos Atos em Filipos pudessem ocorrer, uma lista tão grande de punições vai além do ponderável para um cidadão romano (embora deva ser observado que o respeito estrito dos direitos de cidadãos romanos por parte de autoridades locais venha sendo questionado, cf. SHAW, 2000: 369). Deste modo, é possível que o autor dos Atos dos Apóstolos altere um bocado as condições de prisão e transporte de Paulo de Jerusalém a Roma ao inserir uma pretensa cidadania romana do apóstolo. Afinal, não se esforça o autor por apresentar o novo culto como perfeitamente conciliável com a ordem romana? Quem melhor para difundir esta fé pelo Mediterrâneo que um apóstolo cidadão romano? De qualquer forma, os Atos servem como uma boa testemunha documental das consequências sociais da posse da cidadania romana por um habitante do Império Romano.
} 
colônia romana, onde, portanto, boa parte dos habitantes possuía a mesma cidadania ${ }^{14}$. Após serem sucessivamente agredidos publicamente, encarcerados e libertados milagrosamente, Paulo e Silas recebem a liberação também por parte dos estrategos da cidade:

Fazendo-se dia, os estrategos enviaram os litores (oi $\sigma \tau \rho \alpha \tau \eta \gamma o i)$ ao carcereiro com a seguinte ordem: 'Solta esses homens'. O carcereiro transmitiu tais palavras a Paulo: 'Os estrategos mandam dizer que sejais soltos. Agora, pois, saí e prossegui vosso caminho'. Paulo, porém, replicou aos litores: 'Vergastaram-nos em público sem julgamento, a nós que somos cidadãos romanos (lit: "homens romanos"; $\alpha$ $v \theta \rho \omega ́ \pi 0 v \varsigma ~ P \omega \mu \alpha i ́ o v \varsigma)$, e lançaram-nos à prisão. Agora, é furtivamente que nos mandam sair? Não será assim: eles mesmos venham retirar-nos daqui'. Os litores transmitiram aos estrategos

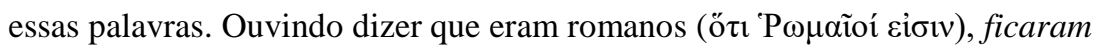
com medo ( $\dot{\varepsilon} \varphi \mathrm{o} \beta \dot{\eta} \theta \eta \sigma \alpha v)$ e vieram pessoalmente insistir com eles para que se afastassem da cidade. (Atos 16,35-39; grifo meu) ${ }^{15}$

O segundo caso ocorre em Jerusalém, quando Paulo é aprisionado pelas autoridades do Templo judaico. O tribuno local, frente ao tumulto, ordena que o apóstolo seja preso e interrogado sob açoites:

Quando o amarraram com correias, Paulo observou ao centurião

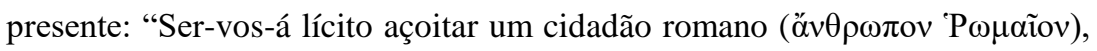
ainda mais sem ter sido condenado?" A estas palavras, o centurião foi ter com o tribuno para preveni-lo: "Que vais fazer? Este homem é cidadão romano!" Vindo então o tribuno, perguntou a Paulo: "Dize-me: tu és romano?" "Sim", respondeu ele. O tribuno retomou: "Precisei de vultoso capital para adquirir

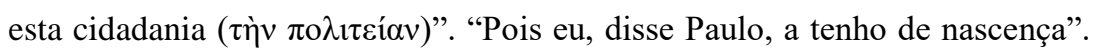
Imediatamente se afastaram dele os que ia torturá-lo. O próprio tribuno teve receio, ao reconhecer que era romano, e que mesmo assim o havia acorrentado.

(Atos 22,25-29)

\footnotetext{
${ }^{14} \mathrm{Tal}$ fato encontra-se pressuposto na acusação que é feita contra Paulo e seu colega Silas: "Estes homens perturbam nossa cidade. São judeus, e propagam costumes que não nos é lícito acolher nem praticar, pois somos romanos" (Atos 16,20-21; ênfase minha).

${ }^{15}$ Note-se que o autor do texto não considera necessário se delongar sobre os privilégios inerentes à cidadania romana, reservando-se ao mero destaque do medo das autoridades frente à afronta cometida de forma inconsciente. Ele sabia que seus leitores teriam perfeito conhecimento da condição jurídica de uma pessoa como Paulo e Silas.
} 
As duas passagens citadas dos Atos dos Apóstolos servem como uma boa representação da distinção jurídica reservada à pessoa que viesse a receber a cidadania romana, como a de ser tratado de forma diferenciada por parte das autoridades locais, embora existam dúvidas na historiografia quanto ao seguimento estrito de tais regras por parte dos magistrados e oficiais romanos locais (SHAW, 2000: 369). Outro privilégio era o de poder apelar para um julgamento pelo próprio César, uma ação que os Atos dos Apóstolos também põem na conta de Paulo ${ }^{16}$. É de se notar, porém, que a cidadania romana não conferia apenas um status jurídico privilegiado, mas servia também como um fator de distinção social, sobretudo fora de Roma e da Itália, para cujas cidades a cidadania havia sido estendida há mais tempo. Note-se a fala do tribuno na segunda citação, onde afirma que havia custado caro a ele adquiri-la. O Império Romano era marcado por tais clivagens sociais em seu interior, cuja existência constituía um dos alicerces da boa ordem romana ${ }^{17}$.

Cumpre, porém, dizer que a extensão da cidadania romana a determinadas pessoas ou grupos sociais tornou-se um dos meios pelos quais o poder central veio a atrair membros destacados das elites locais para o seu apoio ${ }^{18}$. Uma vez mais, nota-se aqui a sempre presente relação de patronato. Ao trabalhar para que os abastados locais possuíssem, além de seu destaque na administração e manutenção da pólis, uma distinção jurídica que lhe permitisse apelar até ele, o imperador transformava-se em patrono dos mesmos e via única pela qual poderiam esperar mais distinções sociais e políticas, para as quais nos voltamos em seguida.

\footnotetext{
${ }^{16}$ Atos 25,9-12: "Então Festo, querendo agradar aos judeus, dirigiu-se a Paulo: 'Queres subir a Jerusalém, para lá, em minha presença, seres julgado a respeito destas coisas?' Paulo, porém, replicou: 'Estou perante

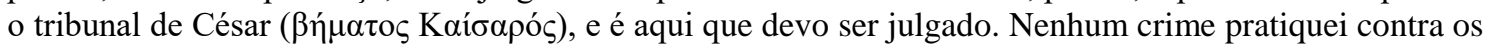
judeus, como tu perfeitamente reconheces. Mas, se de fato cometi injustiça, ou pratiquei algo que mereça a morte, não recuso morrer. Se, ao contrário, não há nada daquilo de que me acusaram, ninguém pode

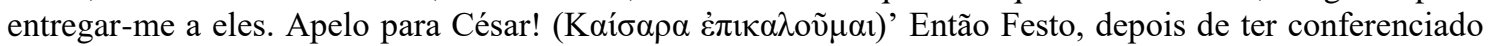
com o seu conselho, respondeu: 'Para César apelaste, perante César irás!"”

17 Veja-se, a esse respeito, Guarinello: "O que a historiografia denomina, muitas vezes, sociedade romana é apenas uma abstração ou a generalização, para o conjunto do Império, de uma realidade que era válida, talvez, para Roma. E isso não apenas pela própria diversidade entre sistemas sociais, como vimos, mas dentro do próprio mundo das cidades. As clivagens sociais separavam cidadãos e não cidadãos (até o século III d.C.), livres e não livres, ricos e pobres, letrados e iletrados, proprietários de terra e trabalhadores manuais, riqueza móvel e riqueza imóvel” (GUARINELLO, 2006: 16).

18 Afirma-o Galsterer: "Cities, it is easy to see, could not be administered without the 'ruling class', the decuriones, and even less against them. This was acknowledged by Rome in giving Roman citizenship to more and more of its members, in making the members of all councils in all the cities one ecumenical and of course wholly fictitious - ordo decurionum, one of the three privileged ordines in the empire, and in making them the reservoir for promotion to the equestrian order" (GALSTERER, 2000: 358).
} 


\subsubsection{2: Acesso à ordem equestre e ao Senado}

O segundo elemento encontra-se intimamente ligado ao primeiro. Podemos afirmar que são os passos a mais, para além da admissão à cidadania romana. Pois um cidadão romano poderia sê-lo e permanecer como uma autoridade local da qual o imperador sempre poderia exigir fidelidade por conta da especial relação patronal existente nesta relação social, inclusive com o acesso à ordem dos decuriões. O segundo passo, inteiramente reservado ao arbítrio do príncipe, era aumentar o status social do abastado em questão e conferir-lhe poder político, inserindo-o em um patamar acima da administração local e conferir-lhe responsabilidades regionais ou mesmo convocá-lo para servir-lhe diretamente no centro imperial (SHAW, 2000: 368). Em ambos os casos, estava envolvida a admissão do candidato a uma nova ordo.

Uma delas era a ordem equestre. O caráter elitista desta ordem é patente ao considerarmos que, para nela ser admitido, o candidato deveria contar com uma fortuna de, no mínimo, 400.000 sestércios. Parte deste valor, contudo, poderia ser fornecido por empréstimo pelo próprio imperador, o que fazia apenas aumentar as obrigações do novo equestre para com seu patrono (MENDES, 2006: 28). A ordem equestre trazia consigo uma série de privilégios. No entanto, os candidatos a adentrar neste grupo seleto não tinham à sua frente apenas a perspectiva de possuir mais privilégios do que aqueles com os quais já contavam. Principalmente após a morte do imperador Cláudio, conhecido por dar preferência aos seus próprios libertos para a administração central do império, os membros da ordem equestre passaram a ser cada vez mais um campo de recrutamento para a composição do governo imperial na capital. A perspectiva de ascensão, não apenas social como política, servia como um bom estímulo para que as elites locais trabalhassem a favor do imperador e permanecessem a ele fiéis, controlando os ânimos da população e mantendo a ordem.

No entanto, não apenas com a ordem equestre poderiam sonhar os abastados provinciais. Sobretudo a partir do fim do século I d.C., cada vez mais membros deste grupo social passaram a ter acesso à ordem suprema do império, da qual, em teoria, participava o próprio príncipe: a senatorial. Certo é que o Senado não constituía mais a potência política que fora até o principado de Augusto (ou mesmo antes, até a ditadura de Júlio César), mas este fator não constituía em nada um empecilho para que os cidadãos romanos que possuíssem no mínimo 1.000.000 de sestércios sonhassem com tamanha 
honra ${ }^{19}$. De fato, os senadores permaneciam a elite da Res Publica, ainda que essa agora fosse organizada de forma imperial ${ }^{20}$. Senadores poderiam receber o encargo do governo de províncias, especialmente aquelas ricas que se encontravam sob responsabilidade do Senado, como a Ásia Proconsular, foco desta pesquisa.

\subsubsection{3: $O$ culto imperial}

Podemos dizer que a principal e mais representativa demonstração da anuência das elites locais ao poder imperial romano era a promoção e difusão do culto imperial, sobretudo a partir da virada dos séculos I e II d.C. Este culto permitia que as províncias locais demonstrassem sua gratidão ao imperador pela manutenção da paz que permitia que as trocas comerciais ocorressem, que a segurança das cidades fosse garantida e que a ordem legal fosse efetivada e executada. Ou seja, era uma manifestação político-religiosa difundida sobretudo por aqueles que mais ganhavam com a ordem romana e que tinham mais condições de bancar a construção de templos e altares, assim como garantir financeiramente a permanência do culto. Talvez uma das testemunhas mais exaltadas do mesmo seja Díon Cássio, que escreve em suas Histórias Romanas:

César [Augusto], enquanto isso, além de comparecer aos negócios gerais, deu permissão para a dedicação de recintos sagrados em Éfeso e em Niceia a Roma e a [Júlio] César, seu pai, a quem nomeou herói Júlio. Essas cidades haviam, nesse tempo, conquistado uma posição elevada na Ásia e na Bitínia respectivamente. Ele comandou que os romanos residentes em tais cidades deveriam venerar essas duas divindades; mas ele permitiu que os estrangeiros, a quem chamava "helenos", a consagrar recintos para si próprio, os asiáticos a ter o seu em Pérgamo e os bitínios o seu em Nicomédia. Tal prática, começando sob ele, foi continuada sob outros imperadores, não só no caso das nações gregas, mas também naquelas todas outras, contanto que estivessem sujeitas aos romanos. (Díon Cássio, Histórias Romanas, LI.20,7; ênfase minha)

\footnotetext{
${ }^{19}$ Vale notar que, mesmo a ordem senatorial possuindo caráter hereditário (ou seja, sendo automaticamente transferida aos filhos homens de um determinado senador), mesmo aqui as exigências censitárias encontravam-se presentes. Afinal, se um pai senador não possuísse a quantia monetária requisitada, seu filho não poderia tornar-se um senador efetivo, a não ser que contasse com a liberalidade do imperador, que poderia efetivá-lo mesmo assim. Deste modo, o princeps possuía uma forma de manter uma relação patronal mesmo com alguns senadores já estabelecidos antes de seu reinado ou de origem tradicional. Cf. CHASTAGNOL, 1992: 155.

${ }^{20}$ Para um elencamento apurado das funções do senado romano durante o período imperial, ver TALBERT, 1984: 341-459.
} 
Como apontam Beard, North e Price, Díon Cássio vê o culto do imperador "como um fator unificador nas religiões do vasto território imperial, um aspecto de culto que todos os súditos romanos compartilhavam" (BEARD, NORTH E PRICE, 1998: 318). Certamente, Cássio serve como uma fonte da larga difusão de tal culto em todo o Império Romano, especialmente na região a qual estudamos aqui, a Ásia Proconsular. No entanto, dois pontos devem ser levantados a respeito. Em primeiro lugar, Cássio escreve já no século III d.C., cerca de um século ou mais do que o período que serve de recorte cronológico para a pesquisa. Deste modo, é possível que ele esteja espelhando no relato que faz de um acontecimento do fim do século I a.C. uma realidade cabível, na verdade, ao período em que está escrevendo. Em segundo lugar, como apontam os mesmos autores citados, deve-se cuidar para que o relato do historiador antigo não conduza à conclusão equivocada de que, em um suposto cenário de decadência dos antigos cultos, aquele dedicado ao imperador em pessoa teria ascendido ao ponto de suplantar os mesmos. Ao invés, devemos considerar que "as identidades primárias das cidades gregas continuaram a ser focadas em seus deuses ancestrais" (Ibidem: 360).

As raízes do culto imperial talvez possam ser traçadas, seguindo Koester, (KOESTER, 2012: 35-41; 369-375) em duas fontes principais. Primeiramente, existia a tendência de um número de cidades de origem grega considerar seu soberano um deus ou a própria manifestação do poder divino, sobretudo quando era capaz de grandes feitos e/ou de garantir a ordem política, social e econômica ${ }^{21}$. Nada mais natural que aplicar a mesma lógica ao imperador romano, considerado o $\beta \alpha \sigma \imath \lambda \varepsilon u ́ \varsigma$ ("rei”) de todo o império, guardião da paz e da ordem no Mediterrâneo. No entanto, uma segunda fonte talvez possa ser traçada em um hábito da própria Roma republicana. Neste caso, não era estranho à norma o próprio Senado votar a admissibilidade do culto ao genius (uma espécie de divindade acompanhante de um determinado indivíduo) de generais responsáveis por grandes empreitadas militares, com grandes benefícios para a Urbs. Tal culto, porém, não era dirigido, como se vê, à própria pessoa do vitorioso (uma ideia que poderia ser encarada pelo Senado como perigosa), mas à divindade responsável por inspirar-lhe os atos

\footnotetext{
${ }^{21}$ Acerca desse ponto, se pronuncia Sartre: "Loin d'être propre à l'Orient grec, le culte impérial y revêtit cependant un caractère particulier en raison des traditions locales déjà anciennes du culte des souverains. Celui-ci, création hellénistique, trouve ses racines dans l'héroïsation et les cultes funéraires grecs. On lui a cherché en vain des origines "orientales », c'est-à-dire égyptiennes, sémitiques ou perses, et chacun s'accorde aujourd'hui à reconnaître que le culte grec des souverains ne doit rien aux coutumes des peuples du Proche-Orient" (SARTRE, 1991: 89).
} 
heroicos. Um passo novo foi dado respectivamente com as mortes de Júlio César e César Augusto: nos dois casos, o Senado decretou que os próprios fossem considerados deuses dignos de culto. Pela primeira vez, o conjunto dos senadores aceitavam declarar a divindade de líderes da Res Publica, ainda que apenas depois de mortos.

No entanto, a tese de Koester apresenta uma fragilidade básica. Ainda que buscando fontes culturais diferentes para o fenômeno, ele se mantém preso à ideia de uma existência do culto imperial. É difícil, porém, falarmos em um único culto ao imperador efetuado em todo o império (BEARD, NORTH E PRICE, 1998: 318). O que temos, ao invés, é uma série de diferentes cultos regionais compartilhando de um mesmo foco, a saber, o culto do imperador, da família imperial como um todo, ou dos predecessores do mesmo. Em outras palavras, o objetivo dos vários cultos imperiais era o mesmo, embora as manifestações e mesmo as raízes culturais fossem diferentes. Assim, ao invés de termos, conforme aponta Koester, diferentes fontes para um mesmo culto, temos desenvolvimentos diferentes de um culto prestado ao imperador em Roma e no oriente helenizado, por exemplo.

Foi necessário, porém, esperar algum tempo até que os próprios imperadores dessem mostras públicas de favorecimento do culto à sua pessoa sem sérias consequências para si. Tibério optou por desestimular tais iniciativas, sabendo que poderiam não ser bem vistas pelo Senado. Calígula estimulou o culto à sua pessoa, inclusive denominando-se dominus et deus ("senhor e deus") e executando o ato temerário de ordenar que uma estátua sua fosse colocada em pleno Templo de Jerusalém (ordem cuja execução foi prudentemente protelada pelo legado local). Acabou sendo assassinado por sua guarda pretoriana, sendo esse talvez um dos motivos.

Importa-nos, porém, o fato de que, por volta do começo do século II d.C., a promoção do culto imperial era uma das principais formas de as elites regionais e locais demonstrarem sua fidelidade ao imperador, que, a partir de Trajano, passou a reservar para si o qualificativo Optimus (“o maior”, “o melhor”), antes reservado a Júpiter, o deus supremo do panteão romano. As elites construíam os templos, as elites iam a Roma requerer sua aceitação por parte do imperador, as elites garantiam sua manutenção. Do mesmo modo, era das classes abastadas que eram selecionados os responsáveis pelo culto, ou seja, seus sacerdotes, como, aliás, era o caso da maioria dos cultos oficiais e públicos da pólis. Tratamos do culto imperial de forma mais detalhada à frente, neste mesmo capítulo, ao tratarmos do caso da Ásia, onde esta manifestação político-religiosa foi particularmente florescente, servindo inclusive como um fator de rivalidade entre as pólis. 


\subsubsection{4: As vantagens econômicas de um Mediterrâneo integrado}

Um quarto elemento que pode ser citado não possui caráter nem institucional e nem religioso. Trata-se da própria integração do mar Mediterrâneo, cuja manutenção e expansão por parte do poder imperial trazia grandes benefícios para as elites abastadas locais, com as quais o imperador buscava ter boas relações.

De fato, ao contrário do que defendia Moses Finley e defende Peter Garnsey, as pesquisas acerca da economia romana sugerem cada vez mais que devemos abandonar a perspectiva de uma produção agrícola e industrial primitiva, voltada unicamente para a própria subsistência. Ao invés, cada vez mais temos a imagem de um Mediterrâneo altamente conectado, no qual a produção voltada para as trocas entre cidades e, inclusive entre regiões, tinha um peso considerável no crescimento e desenvolvimento econômico. É certo que a escala deste desenvolvimento não pode se aproximar dos níveis modernos da sociedade industrializada. No entanto, era suficiente para fazer do Mediterrâneo romano um caso especial de integração econômica.

Como pôde ser visto anteriormente, o governo imperial centrou-se cada vez mais, nos séculos I e II d.C., na garantia do apoio por parte das próprias elites locais. Também já foi citado o fato de apenas os habitantes com um censo mínimo poderem ter acesso às ordines ("ordens"), conforme a legislação formulada no princípio do Principado. Estas elites só poderiam ganhar com a garantia de um mar integrado, com uma segurança maior para a efetuação de trocas comerciais: construção de uma rede gigantesca de estradas pelas quais viagens comerciais terrestres eram estimuladas; o quase aniquilamento da pirataria com a campanha marítima de Pompeu em meados do século I a.C. que garantia um pouco mais de segurança para as naus mercadoras (ainda restando, porém, as imprevisibilidades naturais do Mediterrâneo); a construção e manutenção de estruturas essenciais para a efetuação de trocas comerciais, como fóruns e portos, levada a cabo ou estimulada pelo poder central. Tudo isso favorecia sobremaneira a permanência de uma alta conectividade interna à bacia mediterrânica, tendente a garantir a satisfação daqueles que tinham sua renda baseada na produção e/ou comercialização de produtos, sobretudo agrícolas, o que incluía grandes proprietários de terra que poderiam explorar a mesma diretamente, por meio de trabalho escravo, ou indiretamente, através de arrendatários.

Temos, portanto, neste elemento uma espécie de quadro circular da política romana: a aliança com as elites locais garantia uma maior integração do mar, o que, por sua vez, estimulava a fidelidade das mesmas elites. Ou, talvez, tenhamos um movimento 
de caráter cumulativo: quanto mais o imperador se aliava às elites locais, mais segurança se tinha na alta integração do Mediterrâneo sob sua autoridade, cujas vantagens garantiam ainda mais fidelidade por parte das mesmas elites.

É neste mar altamente integrado economicamente, politicamente e, de forma mais relativa, socialmente, que nossa fonte, Inácio de Antioquia, foi preso, transportado e, ao que tudo indica, executado. Foi durante sua viagem como prisioneiro pelo Mediterrâneo que ele dispôs da alta conectividade e integração, mantidas e favorecidas pelo mesmo poder imperial que lhe servia de carrasco, para comunicar-se com comunidades e pessoas. Uma destas comunidades encontrava-se na capital, destino do líder cristão antioqueno. Outras seis cartas, porém, foram dirigidas a grupos cristãos presentes em centros urbanos de uma região específica dentro de todo o quadro apresentado acima: a província da Ásia Proconsular. E é para ela que, agora, nos voltamos.

\section{2: A província da Ásia Proconsular e suas principais cidades}

A província da Ásia Proconsular, que abrangia boa parte do que hoje seria a costa egeia da Turquia, era certamente uma das regiões mais florescentes do império em termos demográficos, econômicos e culturais, inclusive com o refinamento arquitetônico de seus centros urbanos, a maior parte dos quais são hoje prósperos campos de escavações. Também podemos notar a cada vez maior participação política de elites da província da Ásia no governo central do império. Fazer, portanto, uma narrativa sumária acerca de uma região tão importante do Mediterrâneo romano, ainda mais em seu período de apogeu, apresenta-se como um desafio considerável. No entanto, é certamente necessário que façamos uma contextualização mais local do processo histórico que é o foco desta dissertação. No que ela pode nos ajudar a entender as comunidades cristãs urbanas da região? Iniciaremos, portanto, por uma breve, mas não menos importante, narrativa política acerca da província durante o período de domínio romano. Deixaremos, no entanto, para abordar os períodos anteriores quando viermos a tratar das cidades em específico, focando sempre naquelas das quais temos referências na documentação cristã mais antiga (especialmente Éfeso, Esmirna e Filadélfia, que sobressaem nos documentos). Em seguida, abordaremos as realidades sócio-econômicas locais. Nesse ponto, não poderemos deixar de fazer referência ao papel da agricultura no florescimento econômico da Ásia, mesmo que a ausência de referências a comunidades cristãs na zona 
rural asiática possa desencorajar uma abordagem aprofundada das estruturas sociais existentes nesta porção do território (no qual se encontrava, aliás, o grosso da população).

\subsection{1: A Ásia como província do Império Romano 22}

Ao tempo em que veio a se tornar província romana, boa parte do território da Ásia constituía o reino de Pérgamo, fundado em meio às guerras entre os sucessores de Alexandre. Um deles, Lisímaco da Trácia, inclusive morreu em batalha pelas mãos de outro, Seleuco, próximo a Magnésia do Meandro em 281 a.C., cidade na qual futuramente viria a ser fundada uma comunidade cristã endereçada por Inácio de Antioquia. Como é evidente, o reino centrava-se em Pérgamo, cidade rica econômica e culturalmente, sendo um dos grandes centros de difusão da cultura grega pelo Mediterrâneo oriental. Havia, no entanto, outras cidades prósperas em termos econômicos, como Éfeso, por exemplo, cidade portuária já em desenvolvimento considerável. Seria ainda um longo caminho, porém, até que a cidade costeira viesse a desbancar Pérgamo como a metrópole da região.

Antes, era necessário que o próprio reino de Pérgamo viesse a desaparecer, e isso aconteceu quando o rei Átalo III Filómetor morreu, deixando todo o território de seu reino como herança à república romana. Obviamente tal processo não ocorreria sem resistência, mas ela não foi duradoura. Um irmão ilegítimo do rei morto não aceitou a validade do testamento e tentou manter o reino independente, mas foi derrotado pelos romanos, conduzido a Roma e lá executado, sendo o território do reino convertido na província da Ásia. Isso tudo ocorreu em 133 a.C.

Com a reorganização do poder, os centros urbanos locais continuaram se expandindo e se desenvolvendo economicamente. O potencial de Éfeso, em especial, já era considerado em um período bem anterior, como se vê pela tentativa (falha) do rei pergameno Átalo II Filadelfo de conter o processo de assoreamento do porto, conforme narrado por Estrabão, em Geografia 14.1.24:

A cidade [Éfeso] possui tanto um estaleiro quanto um porto. A boca do porto foi feita de forma estreita pelos engenheiros, mas eles acabaram iludidos, junto com o rei que havia ordenado a obra, este sendo Átalo Filadelfo; pois ele considerava que a boca do porto seria profunda o suficiente para grandes

\footnotetext{
${ }^{22}$ Para uma narrativa mais detalhada sobre a região abrangida pela província da Ásia Proconsular, antes e depois da chegada de Roma, ler GRUEN, 1984: 529-610.
} 
navios mercantes - assim como o próprio porto, que antes possuía pontos rasos por conta do lodo depositado pelo rio Caíster - se um molhe fosse lançado à boca, que era muito larga, e, desse modo, ordenou que o molhe deveria ser construído. O resultado, contudo, foi o contrário, pois o lodo, encurralado desta forma, fez todo o porto, até a boca, mais raso. Antes disso, a vazante e o fluxo das marés levavam embora o lodo e o despejavam no mar, fora do porto.

Mesmo considerando a obra fracassada do rei Átalo II Filadelfo, Estrabão conclui que Éfeso, "por causa de sua posição vantajosa em outros aspectos, cresce diariamente, e é o maior ponto mercantil na Ásia deste lado do [rio] Tauro". Tal prosperidade poderia ter origem de longa data, ainda que sujeita a possíveis flutuações, se tivermos em conta a instabilidade política da região nos últimos quatro séculos antes de Cristo. François Kirbihler argumenta por um crescimento considerável da população sobretudo a partir do século IV, embarcando em um processo contínuo até o tempo de Plutarco (e Inácio de Antioquia) mas não sem crises (KIRBIHLER, 2009: 307) ${ }^{23}$. No entanto, não só Pérgamo e Éfeso se destacavam progressivamente na rede comercial da Ásia e do Mediterrâneo, como também outras cidades, como Mileto, um porto próspero de longa data, e Esmirna, outro porto que vinha se desenvolvendo economicamente desde pelo menos o período em que esteve sob o domínio do rei de Pérgamo. A antiga Esmirna havia sido uma colônia eoliana, ocupada posteriormente por ionianos de Cólofon e destruída não antes do século VII a.C., conforme apontam as escavações locais (HEMER, 1986: 61), vindo a ser refundada como uma pólis por volta de 290 a.C., com um crescimento econômico acentuado sobretudo no período no qual se foca nosso estudo. Deixamos para tratar, contudo, dos aspectos sócio-econômicos da província de uma forma um pouco mais pormenorizada na próxima subseção.

O crescimento praticamente contínuo da região, no entanto, não estava a salvo de reveses políticos, sobretudo conforme as posições tomadas pelas pólis da Ásia nas guerras do fim do período republicano de Roma. Um exemplo é o da chamada guerra mitridática, quando Mitrídates VI Eupátor, rei do Ponto, lutou contra a dominação romana em toda a Ásia Menor e na Grécia, aproveitando-se dos problemas internos da república romana na Itália, acossada pela Guerra Social. Uma das iniciativas de Mitrídates foi a de ordenar que

\footnotetext{
23 “Éphèse se développa beaucoup par la suíte, non sans crises cependant. L'action de Lysandre, la création d'un arsenal et la reprise des activités artisanale et commerciale enclenchent un processus de croissance qui aurait été un phénomène continu de la fin de la guerre du Péloponnèse jusqu'au temps de Plutarque. Le IVe siècle av. J.-C. a par consequente correspondu à um premier moment d'essor important" (KIRBIHLER, 2009: 307).
} 
todas as cidades sob o seu comando (incluindo àquelas anteriormente pertencentes à província romana da Ásia) executassem todos os habitantes de origem italiana que se encontrassem em seu meio. Aparentemente, 80.000 pessoas oriundas da Itália foram mortas nesta ocasião, inclusive em grandes cidades como Éfeso. Mesmo aceitando participar do morticínio, muitas das mesmas pólis (incluindo Éfeso) vieram a se revoltar contra o rei do Ponto, sendo severamente reprimidas. A punição por parte de Roma veio com o general Sula, que retirou de Éfeso a sua liberdade em 84 a.C., liberdade que apenas reconquistaria em 47 a.C.

Desde a criação da província da Ásia em 133 a.C., a capital da província havia permanecido em Pérgamo. De fato, como capital do antigo reino atálida, Pérgamo reunia uma série de requisitos e estruturas básicas para receber o governo provincial romano, que afinal, como vimos anteriormente, não contava com um aparato estatal pesado. A favor de Pérgamo estavam também seu papel crucial na economia regional, especialmente na viticultura amplamente explorada em seu entorno, e seu legado cultural e religioso, tanto como um centro de conservação e ensino da alta cultura grega, quanto como a cidade que continha o templo de Dionísio. A primeira reorganização da hierarquia e poder regionais veio com Augusto, que, mesmo com o apoio dado por Éfeso a seus inimigos Marco Antônio e Cléopatra, não só garantiu à mesma cidade uma liberdade ao menos nominal, como a elevou a capital da província da Ásia Proconsular, destronando, portanto, Pérgamo de seu posto. Não se sabe exatamente o porquê de Augusto ter tomado tal iniciativa. Trebilco (TREBILCO, 2004: 13) sugere duas possibilidades nãoexcludentes.

Em primeiro lugar, é possível que Augusto levasse em conta a posição geográfica estratégica de Éfeso em contraposição à de Pérgamo. Ao mesmo tempo que era uma cidade portuária banhada pelo mar Egeu, encontrava-se localizada em meio a um número considerável de rotas comerciais terrestres (TREBILCO, 2004: 17). No mar, o tráfego marítimo do Egeu a oeste, do Bósforo e dos Dardanelos ao norte, da Palestina a leste e do Egito ao sul, desembocava todo em Éfeso. Em terra, a metrópole asiática encontrava-se conectada por boas rotas para o norte (dirigindo-se a Pérgamo, inclusive) e, ao sul, duas grandes estradas a ligavam ao leste: a antiga estrada real persa, aquela conhecida como

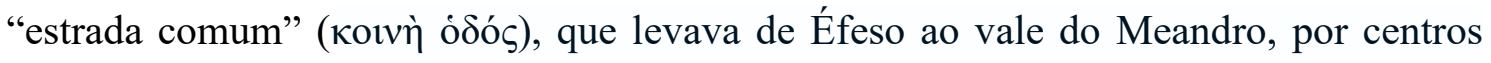
urbanos como Trália (que contava com uma das comunidades cristãs endereçadas por Inácio de Antioquia), Nysa e Antioquia da Pisídia, seguindo então em frente até alcançar o rio Eufrates; e outra estrada que ligava a metrópole a outra cidade da Ásia, Sardes (esta 
contendo uma comunidade cristã endereçada por João de Patmos em seu Apocalipse), acessando aí uma outra estrada real persa que levava a Susa, para além da Mesopotâmia, cortando a província da Galácia, ainda na Ásia Menor $^{24}$. Considerando o crescimento quase que constante de seu poderio econômico e, consequentemente, de sua população, Éfeso poderia ser encarada como a opção mais óbvia para se estabelecer o governo provincial, levando-se em conta sua conectividade.

Uma outra possibilidade é a de que Éfeso, como cidade ainda em desenvolvimento, oferecesse maiores possibilidades de intervenções urbanísticas por parte de Augusto, um ponto crucial em sua política de autoafirmação, tanto na capital quanto nas províncias. Por meio da encomenda de grandes construções para o bem público da pólis, o príncipe tanto expressava visivelmente sua política de Pax Romana quanto reforçava sua posição como patrono dos cidadãos da província em questão. Pérgamo, em sua posição de capital do antigo reino atálida, poderia não garantir um mesmo campo no qual Augusto pudesse trabalhar (TREBILCO, 2004: 13-4). Isso não significa, no entanto, que o imperador passasse a desconsiderar a importância precedente de Pérgamo tanto simbolicamente quanto estrategicamente. Coerente com a política conservadora de Augusto, o primeiro culto provincial foi estabelecido na antiga capital atálida, ao invés de ser organizado em Éfeso, assim como a sede do koinon, ou associação político-religiosa das cidades da Ásia, também foi nela estabelecida ${ }^{25}$. Deste modo, o imperador visava garantir às cidades locais que, apesar de ser um novo governante com autoridade sobre elas, era um que se mantinha em continuidade com o passado.

No entanto, Augusto certamente atuou de forma decisiva para transferir o pólo de poder e prestígio na região para Éfeso. Uma dessas medidas, de caráter altamente representativo, é a concessão dada para que Éfeso pudesse dedicar recintos sagrados à Dea Roma e a Diuus Iulius (ao mesmo tempo que, prudentemente, selecionou Pérgamo

\footnotetext{
${ }^{24}$ Outra indicação dada por Trebilco da localização estratégica de Éfeso é o fato de a mesma cidade possuir um colégio de tabelarii (isto é, mensageiros ou corredores): "Roman military control and the efficiency of their administration depended on rapid communications and so the romans devised an elaborate series of communication networks. Ephesus, as the base of the college of tabelarii, was the centre of the Romans' communications network for Asia and courier routes would have radiated from Ephesus to all administrative centres of the province" (TREBILCO, 2004: 18). As redes de comunicação que contavam com Éfeso como centro serão importantes quando analisarmos, nos próximos capítulos, a difusão do cristianismo pela Ásia e a utilização que faz Inácio de Antioquia de cristãos efésios para garantir o transporte de algumas de suas cartas ao seu destino.

${ }^{25}$ Deve ser notado, contudo, que as sedes das koinon eram sempre cidades que não a capital da respectiva província, ao menos nas da Ásia Menor. Cf. SARTRE, 1991: 247.
} 
para o estabelecimento de um culto imperial) ${ }^{26}$. A elevação do status de Éfeso também se mostra no aumento no número de doações e construções de edifícios públicos durante todo o século I e seguindo pelo II d.C., acrescentados ao já grandioso Artemision, o gigantesco templo dedicado à Ártemis de Éfeso, um dos principais centros da religiosidade local. A maior parte dos monumentos já existentes foram restaurados durante o, ou a partir do principado de Augusto, e muitos outros foram construídos ${ }^{27}$.

Durante os principados dos Flávios (Vespasiano, Tito e Domiciano) não só a província da Ásia como toda a Ásia Menor, agrupando províncias como a Bitínia e as recém-fundadas Galácia-Capadócia e Lícia-Panfília, passou por um período de grande prosperidade econômica. Havia certa lógica cultural em tal medida (LEVICK, 2000: 605), considerando o caráter fortemente mais helenizado da costa oeste da Ásia Menor se comparada às regiões interioranas, no centro da Anatólia (SARTRE, 1991: 243). A reorganização administrativa efetuada por Vespasiano foi de grande sucesso, garantindo a presença efetiva romana na península de forma especial pela escolha de governadores competentes. No entanto, nenhum indivíduo ou dinastia pode afirmar ter uma parte decisiva do crédito pelo sucesso da Ásia Menor neste período (LEVICK, 2000: 608). Não só a produtividade no campo (afinal, o setor econômico mais importante para o império) e a fertilidade atuavam para a prosperidade, como também a sua posição estratégica para as redes comerciais, especialmente durante o século I d.C. Vale, porém, notar que as cidades da Ásia Menor, em geral (e da província da Ásia Proconsular em particular), foram consideravelmente favorecidas pelo poder imperial após apoiarem a ascensão de Vespasiano ao poder, o que se vê pela fatia de nativos da península aceitos no Senado: dos nove oriundos do Mediterrâneo oriental, que sabemos ter Vespasiano aceito no colegiado máximo da Res Publica, sete eram da Ásia Menor, sendo três deles especificamente de cidades da Ásia, Ti. Júlio Celso Polemeno de Sardes, e C. Âncio A. Júlio Quadrato e C. Júlio Basso de Pérgamo. Note-se, aqui, o prestígio ainda reservado a Pérgamo como antiga capital atálida, tendo dois nomes aceitos. Nesta primeira lista,

\footnotetext{
${ }^{26}$ Não apenas Éfeso, como também Niceia. Dio Cássio afirma que a escolha de tais cidades se deu porque elas "tinham, naquele tempo, conquistado o primeiro lugar na Ásia e na Bitínia, respectivamente" (Historiae Romanae 51.20.6; Trad.: TREBILCO, 2004: 14). Deve-se notar, contudo, que Dio Cássio escreve em um período bem posterior, já no século III d.C.

${ }^{27}$ Trebilco oferece a seguinte lista de edifícios "notáveis" para os visitantes de Éfeso: o templo de Ártemis, o Portão Magnésio, a Alta Ágora (contando com uma basílica construída por Augusto), o Bouleuterion, o templo de Dea Roma e Diuus Iulius, o Pritaneion, o monumento a Mêmio, o templo de Ísis ou Augusto, o monumento de Pólio, uma estrutura octogonal, o Heroon de Ândroclo, o portão de Mazeu e Mitrídates, Ágora Tetragonos, a Casa da Fonte, o palácio do procônsul, o teatro, o portão do porto, o templo de Apolo, o Stadium e o portão Koressos. Cf. TREBILCO, 2004: 15-6).
} 
porém, nenhum oriundo especificamente de Éfeso, a nova capital da Ásia, e nem de outras cidades importantes da região como Esmirna e Filadélfia, com a exceção de Sardes, representada por um senador.

Do mesmo modo, não é possível dizermos que os imperadores ou mesmo os procônsules da Ásia, representantes maiores do poder romano na província, interviessem com frequência e que, deste modo, o desenvolvimento da Ásia se devia a uma boa administração do local por Roma. De fato, como visto anteriormente, o poder romano não se garantia regionalmente por uma mera imposição externa, mas contava com as autoridades locais, tanto das pólis quanto do koinon da Ásia (isto é, a liga das várias cidades da província), para garantir a estabilidade sócio-política regional. Assim, tais agentes locais podiam agir com considerável autonomia, mesmo frente ao procônsul, do mesmo modo que as prescrições do último poderiam se mostrar deveras ineficazes. Werner Eck cita um caso para ilustrar este ponto, retirado de inscrições de Éfeso. Os oficiais responsáveis pelo abastecimento de água da cidade recorreram duas vezes ao procônsul no curso de sete anos (a primeira vez em 113/114 d.C. e a segunda em 120/121 d.C.), por se considerarem incapazes de efetivar a lei que requeria a existência de uma zona livre em ambos os lados dos aquedutos responsáveis por abastecer Éfeso. Eck conclui que o episódio "mostra quão ineficaz poderia ser uma decisão tomada pelo mais alto oficial romano na província, mesmo com uma grande multa sendo estabelecida para os transgressores" (ECK, 2000: 275-6). Podemos notar também como nenhuma autoridade distintamente romana atua no caso da revolta dos artesãos relatado pelos Atos dos Apóstolos (Atos 19,23-40), embora o episódio ocorra justamente em Éfeso, capital da província e sede do procônsul ${ }^{28}$. Ao invés, os únicos magistrados citados são asiarcas ( $\tau \tilde{\omega} \nu$ 'A $\sigma \iota \rho \chi \tilde{\omega} v)$, que impedem Paulo de ir ao teatro enfrentar a multidão, e um escriba (ó

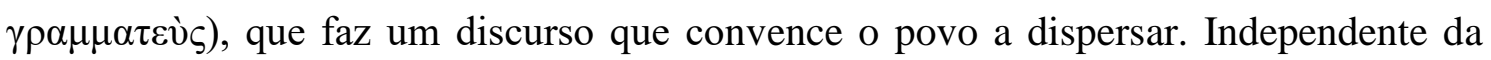
historicidade do relato dos $\operatorname{Atos}^{29}$, é interessante que ele reflita uma certa autonomia da pólis em gerir um problema tão grande quanto um motim levado a cabo por toda uma classe de trabalhadores artesanais (no caso, fabricantes de imagens esculpidas da Ártemis Efésia), embora deva-se notar o ponto nodal do discurso do escriba: "De mais a mais, estamos correndo o risco de ser acusados de sedição pelo que hoje aconteceu, não

\footnotetext{
${ }^{28}$ Deve-se considerar, porém, que o procônsul e governadores em geral não ficavam (ou apenas não deveriam ficar) fixos todo o tempo na caput provinciae, mas deveriam circular pelas cidades da província, de modo a presidir litigações locais e tratar de negócios com notáveis fora da metrópole principal. Cf. GALSTERER, 2000: 347.

${ }^{29}$ Sobre este ponto, cf. TREBILCO, 2004: 157-168.
} 
havendo causa alguma que possamos alegar, para justificar esta aglomeração" (Atos 19,40). Como dito anteriormente, a cidade se geria como aliada a Roma, porém tendo também a sombra ameaçadora do poder romano sempre presente em mente.

Foi com os imperadores Antoninos (Nerva, Trajano, Adriano, Antonino Pio, Lúcio Vero, Marco Aurélio e Cômodo) que se estreitaram definitivamente os laços de fidelidade entre as elites locais e o poder central. Um número cada vez maior de membros das aristocracias locais passou a ser elevado aos postos mais altos do império, com uma afluência cada vez maior de altos cidadãos da região no Senado (LEVICK, 2000: 612-3). Neste mesmo período, abrangendo todo o século II d.C., as cidades da Ásia assistiram a um surto de grandes construções, representação visível tanto do grande favorecimento por parte dos imperadores e do considerável crescimento econômico da região e de sua relevância para o império como um todo (SARTRE, 1991: 285).

No entanto, para entendermos melhor o grande desenvolvimento econômico da Ásia no período Antonino (que, afinal, nos interessa mais, tendo-se em conta que é aquele no qual é universalmente datada a correspondência de Inácio de Antioquia), precisamos partir para uma outra escala de análise, apresentando as estruturas sócio-econômicas da província asiática em uma subseção dedicada unicamente às mesmas.

\subsection{2: Sociedade e economia na província da Ásia Proconsular}

Antes de traçarmos um quadro acerca dos aspectos sócio-econômicos da economia da província da Ásia, precisamos levar em conta tudo o que já foi dito até aqui, a saber, que a dita região, longe de se encontrar isolada de outros pontos do Mediterrâneo, estava imbricada em uma complexa rede de comunicações e trocas que expressa bem a integração do mar sob o domínio romano. Em outras palavras, não se pode pensar a economia asiática sem antes considerar os aspectos da economia no Império Romano em um todo. Tal realidade dirige-nos a um posicionamento no complexo debate acerca da economia romana, o qual pode ser divido, de forma geral (e imperfeita), entre primitivistas e modernistas.

A tese primitivista foi defendida e embasada sobretudo pelo historiador Moses Finley na segunda metade do século XX. Para Finley, a economia romana dirigia-se sobretudo à subsistência dos centros urbanos, sendo que a maior parte da população vivia nos campos. Não que não houvessem trocas comerciais, mas essas não estariam voltadas 
para uma lógica capitalista de incremento da produtividade com o fim de gerar mais lucros. Nas palavras do próprio Finley:

Resumindo, a forte tendência para adquirir riqueza não se traduzia numa tendência para criar capital; dito de outro modo, a mentalidade dominante era aquisitiva mas não produtiva. (...) Os empresários, os homens que dirigiam o comércio marítimo em larga escala ou que emprestavam dinheiro, a "burguesia" de Rostovtzeff, estavam na sua maioria isentos das obrigações e distrações da administração municipal ou imperial; eles são os homens que se esperaria ver criar e desenvolver novas técnicas de formação de capital - e não o fizeram. (FINLEY, 1986: 200).

Apesar de o trecho citado servir como uma boa imagem da teoria primitivista de Finley, ela possui alguns elementos-chave que são elencados por David Mattingly (MATTINGLY, 2006: 284): uma ênfase na agricultura de subsistência; o papel das cidades como centros de consumo, antes que de comércio e indústria; o baixo status social dos artesãos; a difusão tecnológica retardada; e uma falta de racionalidade econômica, ilustrada pelo baixo nível de investimento de capital não-agrário. Outros autores que defendem a teoria primitivista são Peter Garnsey e Richard Saller. Em The Roman Empire: Economy, Society and Culture eles se expressam da seguinte forma quanto à economia no Império Romano:

The Roman economy was underdeveloped. This means essentially that the mass of the population lived at or near the subsistence level. In a typical underdeveloped, pre-industrial economy, a large proportion of the labour force is employed in agriculture, which is the main avenue for investment and source of wealth. The level of investment in manufacturing industries is low. Resources that might in theory be devoted to growth-inducing investment are diverted into consumption or into unproductive speculation and usury. Demand for manufactured goods is relatively low, and most needs are met locally with goods made by small craftsmen or at home. Backward technology is a further barrier to increased productivity. Finally, there is no class of entrepreneurs who are both capable of perceiving opportunities for profit in large-scale organization of manufacture and prepared to undergo the risks entailed in making the necessary investment. (GARNSEY e SALLER, 1987: 
Como podemos notar a partir da citação de sua obra acima, Finley não adotou a perspectiva primitivista sem qualquer razão. Tratou-se, antes, de uma reação ao trabalho de outro estudioso clássico do Império Romano, Mikhail Rostovtzeff. Apesar de Rostovtzeff ter contribuído de forma gigantesca para as pesquisas sobre o Mediterrâneo romano, principalmente por sua utilização maciça de fontes arqueológicas, tendia por outro lado a equacionar demais a economia romana com as tendências e comportamentos econômicos modernos, a saber, próprios do mundo industrial (MATTINGLY, 2006: 286). Deste modo, Finley dedicou-se a criticar tal visão, a segunda que devemos elencar aqui, normalmente denominada entre os estudiosos como "modernista", ou seja, aquela que enxerga tendências na economia romana que seriam, no mínimo, análogas ao processo econômico moderno, como uma lógica de lucro e busca de maior produtividade no trabalho, tanto rural quanto artesanal urbano.

No entanto, um ponto fraco do trabalho de Finley é sua considerável dependência de fontes literárias, o que o leva por vezes a assumir como factuais as perspectivas próprias daqueles setores sociais que eram os maiores responsáveis pela produção de tal documentação, a saber, as elites, tanto na escala imperial quanto na regional e local. A historiografia mais recente, contudo, vem cada vez mais pendendo para uma visão da atividade econômica romana como "significativamente mais alta que aquela alcançada na maioria das sociedades pré-industriais” (MATTINGLY, 2006: 286). Tal sentido das pesquisas se deve, sobretudo, a uma utilização cada vez maior de evidências arqueológicas, uma tendência que tem em Rostovtzeff um dos seus fundadores dentre os antiquistas e romanistas, e cuja pouca utilização é uma das principais fraquezas na obra de Finley, o que traz consequências drásticas para sua tese como um todo ${ }^{30}$. David Mattingly resume da seguinte forma a tendência majoritária dos estudos recentes, em algo que soa quase como uma resposta direta a Finley e Garnsey:

Whilst Roman economic concepts and structures were different from modern ones, that does not necessarily justify characterizing them as primitive

\footnotetext{
30 "A evidência arqueológica, para o estudioso da economia antiga, por sua parte, mostra-se essencial ao fornecer elementos que ultrapassem os horizontes homogeneizadores das abordagens normativas que tomam os discursos de alguns autores antigos como reveladores de um Idealtypus citadino, consumidor, irracional, primitivo e uniforme. A Arqueologia permite observar o quão complexa, diversa e heterogênea era a economia e sociedade romanas durante o Principado. O avanço de nosso conhecimento da economia romana durante o Principado dependerá, portanto, não da aplicação de modelos normativos e homogeneizadores, mas da multiplicação de estudos específicos que busquem explicar a diversidade de situações históricas concretas e, para isso, a Arqueologia terá muito a contribuir" (FUNARI e GARRAFFONI, 2006: 60-1).
} 
or underdeveloped. By the standards of pre-industrial societies, the Roman economy was vast in scale and surprisingly sophisticated in many of its practices. There are indications in papyri, for instance, that economic rationalism underlay some complex accounting processes. Impressive levels of management can also be traced in areas of craft production. The Roman economy involved the interplay of rural and urban production, the exploitation of labor (including a significant level of slavery within Italy), and the infrastructures of exchange. (MATTINGLY, 2006: 286-7)

As cidades da Ásia, deste modo, não consistiam em simples centros consumidores dos produtos agrícolas produzidos em suas vastas áreas rurais interioranas, com apenas algum pequeno comércio feito com outras regiões. Ao contrário, cidades como Éfeso e Esmirna encontravam-se imbricadas em uma ampla rede econômica de produção e comércio de porte considerável em comparação com outras sociedades pré-industriais. $\mathrm{O}$ fato de ambas as cidades (em conjunto com Pérgamo) estarem estreitamente ligadas ao mar conferia-lhes grandes vantagens, uma vez que o transporte por água (tanto por mares quanto por rios) era em geral preferido ao transporte por terra, por conta, principalmente, dos baixos custos envolvidos se comparado ao feito por via terrestre (HARRIS, 2000: 714-6). A preferência pela água no transporte de bens, principalmente agrícolas, é patente nas fontes. Columela, por exemplo, espera que a fortuna conceda ao proprietário estabelecer sua propriedade perto do mar ou de um rio navegável, "pelos quais seus produtos possam ser levados e bens trazidos" (quo deportari fructus et perquod merces invehi possint; De Res Rustica I.2.3; trad.: HARRIS, 2000: 714). Do mesmo modo, Estrabão dá uma clara preferência aos rios como meios de transporte de produtos, embora sua ênfase neste ponto se dê em suas descrições da Gália, dos Alpes e da Itália (Geografia IV e V; cf. HARRIS, 2000: 714). Já quanto ao transporte marítimo, Cícero, navegando rumo a Éfeso por meio de Delos, afirma a Ático que "uma viagem marítima é um negócio sério [negotium magnum est navigare], e no mês de julho também" (Ad Atticum V.12.1). Deste modo, parece inferir o senador que navegar poderia vir a se tornar uma questão perigosa, mesmo durante o mês de julho, considerado um dos mais favoráveis para se embarcar e viajar por mar (STE. CROIX, 1981: 12).

No caso da região na qual nos focamos, uma série de fatores nos séculos I e II d.C. potencializaram economicamente a já estratégica localização das cidades da costa asiática, que contavam tanto com rios como com o mar Egeu para conduzir seus produtos 
para outras regiões, assim como para servir de ponto de passagem para mercadores de outras províncias produtivas. De início, devemos considerar a fertilidade própria das regiões interioranas da província da Ásia, mas também podemos notar as ações do governo imperial que viriam a aumentar o fluxo comercial na região, a começar pela abertura das regiões orientais da península da Ásia Menor, como a Capadócia e a Galácia, o que garantia uma conexão direta, como já visto, com as partes mais a oriente do Império Romano e daí para além, chegando mesmo à Índia e à China; as cidades asiáticas às margens do Egeu eram pontos privilegiados para a passagem de tais mercadorias a caminho de outros centros urbanos mais a oeste, como Tessalônica, Corinto e, principalmente, a capital Roma, a grande consumidora de produtos de luxo no Império. A ação favorável por parte dos imperadores, contudo, não se restringe aí. As conquistas de novos territórios às margens do Danúbio tiveram como consequência direta a criação de novos mercados para as cidades da Ásia, assim como as legiões estacionadas ao leste da península ${ }^{31}$.

Quanto à produção agrícola, devido à fertilidade da terra, muito poderia ser plantado e criado, como no caso do gado ovino, cuja lã abastecia a produção de vestimentas tendo essa matéria-prima como base (SARTRE, 1991: 256). O vinho parece ter sido um produto de especial destaque da região, mas não sem a ameaça de ser substituído por outras culturas (Ibidem: 255). Levick anota um caso descrito por Filóstrato no período de Domiciano: para prevenir a extirpação de metade das vinhas da região, o sofista Escopeliano de Esmirna teria viajado a Roma, de modo a apelar ao imperador por sua causa. Teria ele sido tão persuasivo que Domiciano veio a ordenar que os agricultores da região plantassem vinhas ao invés de destruí-las. Levick conclui que, se o episódio tiver algum embasamento factual, demonstraria uma falta de comprometimento das autoridades locais e centrais com a viticultura diante da onda de escassez de grãos que veio a atingir a Ásia Menor e outras regiões do Mediterrâneo no mesmo período (LEVICK, 2000: 610). Por outro lado, mesmo considerando a importância da viticultura na economia local, "praticamente toda província do Império Romano poderia produzir seu próprio vinho" (HARRIS, 2000: 719), o que nos faz levantar a questão do quanto poderia este bem ter um peso considerável para a economia asiática, pelo menos no que tange o comércio inter-regional. Algumas fontes, contudo, sugerem um considerável

\footnotetext{
${ }^{31}$ Cf. LEVICK, 2000: 608.
} 
transporte do produto entre províncias do império, entre elas um trecho do Pedagogo, do autor cristão Clemente de Alexandria, que escreve por volta do fim do século II d.C.:

Os cuidados que tomamos para procurar vinhos no além-mar são efeitos de uma alma abrumada pela intemperança e pelas paixões; a desordem dos desejos tira a razão antes mesmo que a embriaguez a tire. Vamos até Lesbos por esse vinho de aroma tão agradável; o de Creta é de um sabor maravilhoso; já o de Siracusa é recomendado pela sua doçura; o do Egito e o de Náxos, insular, assim como um certo vinho da Itália, sem falar de todos os outros. (Pedagogo II.2)

O trecho citado parece sugerir que Clemente, escrevendo em Alexandria, tem em mente as regiões de onde a enorme população da cidade egípcia poderia conseguir seu vinho (HARRIS, 2000: 720). Note-se que o autor cristão faz referência ao vinho da ilha de Lesbos, que, à época, encontrava-se agregada à província da Ásia Proconsular. Sendo a ilha citada de modo a representar o vinho de toda região ou não (considerando-se que a viticultura era marcante também pelo menos nas terras e aldeias sob a jurisdição de Pérgamo e Esmirna), certo é que, antes de alcançar Alexandria, o vinho de Lesbos teria que passar pelos portos de Esmirna e/ou Éfeso, na rota de cabotagem percorrida pelos navios mercantes.

A produção agrícola, contudo, não envolve apenas relações econômicas de produção, compra e venda de produtos, mas também relações sociais de propriedade da terra e do trabalho. Quem possuía a terra? Quem a trabalhava? Rostovtzeff optava por não traçar uma única forma de relação de posse e trabalho da terra ${ }^{32}$. Inferia, ao invés, que pequenas e grandes propriedades poderiam ser encontradas nas cidades de origem grega em toda a Ásia Menor, sobretudo naquelas costeiras, podendo ser trabalhadas tanto por escravos quanto por arrendatários. Estas áreas agrícolas eram referidas pelos habitantes da Ásia e das regiões da Grécia como $\chi \omega ́ \rho \alpha^{33}$. Na Ásia especificamente, segundo Ste. Croix, elas teriam, à época de Alexandre e seus sucessores, estado sob o domínio direto do rei, sendo colocadas em contraposição às pólis, às quais tinham a

\footnotetext{
${ }^{32}$ Do mesmo modo se expressa Sartre. Cf. SARTRE, 1991: 257.

${ }^{33}$ A respeito do termo $\chi \omega ́ \rho \alpha$, diz Ste. Croix: "In the Archaic and Classical periods, in Greece itself and in some of the early Greek colonies in Italy and Sicily and on the west coast of Asia Minor, the word chora $(\chi \omega ́ \rho \alpha)$ was often used as a synonym for the agroi (the fields), the rural area of the city-state, the polis ( $\pi$ ó $\lambda(\varsigma)$; and sometimes the word polis itself. in the special limited sense of its urban area, was contrasted with its chora. This usage continued in the Hellenistic period and under Roman rule: every polis had its own chora in the sense of its own rural area." (STE. CROIX, 1981: 9)
} 
responsabilidade de suprir com os frutos da terra. Durante o período romano, contudo, aos poucos tais territórios foram sendo colocados progressivamente sob a jurisdição das mesmas pólis, responsáveis por nomear magistrados e representantes nas aldeias para garantir a manutenção da ordem ${ }^{34}$. Ao mesmo tempo, pode ser constatada uma possível diminuição no número de pequenas propriedades de cidadãos das pólis em favor de grandes propriedades, tanto imperiais quanto pertencentes a grandes proprietários particulares, aristocratas ou não (SARTRE, 1991: 257-8) ${ }^{35}$.

Por muito tempo a historiografia antiquária cultivou a imagem do arrendatário romano oprimido pelo proprietário (imperial ou privado) de suas terras por meio de taxas e subvenções abusivas, sempre com o apoio do poder central do império. Dentro desta historiografia encontra-se o próprio Ste. Croix, para o qual o Império Romano em sua fatia grega ${ }^{36}$ pode ser dividido sociologicamente, ao menos no que tange a propriedade da terra, em dois grandes grupos: proprietários e explorados ${ }^{37}$. Pesquisas mais recentes como a de Dennis P. Kehoe, contudo, têm sugerido cada vez mais um quadro diferente, no qual os arrendatários surgem com autonomia cada vez maior frente aos proprietários de terra (inclusive na reivindicação de direitos frente à autoridade local, regional ou central) e o poder imperial age de forma um tanto quanto neutra, por vezes colocando-se a favor dos próprios arrendatários frente aos grandes proprietários ${ }^{38}$. No entanto, certo é que, mesmo se adotarmos uma visão junto de Kehoe, com os camponeses arrendatários possuindo por vezes mais direitos do que poderíamos imaginar, este fato não diminuía em nada o prestígio e o poder daqueles que possuíam propriedades vastas, ainda que sendo distribuídas geograficamente. A posse de terras era um traço marcante principalmente da elite tradicional das cidades, sendo uma das principais fontes de renda em seu caixa, de onde saíam as contribuições para o bem coletivo (ou "evergetismo").

No caso da Ásia, o aparente aumento no número de grandes propriedades, concorrente à diminuição da ocorrência de pequenos e médios proprietários intimamente conectados à forma grega clássica de propriedade da terra, não nos deve necessariamente

\footnotetext{
${ }^{34}$ Cf. Ibidem: 10. Ver, também, a nota 10 deste capítulo.

35 "Cet amenuisement de la petite, voire de la moyenne propriété, n'est pas invraisemblable lorsque l'on constate qu'à côté des riches propriétaires grecs existent aussi grands domaines tenus par des étrangers et par l'empereur" (SARTRE, $1991: 258$ ).

${ }^{36}$ Ste. Croix define como "mundo grego" uma área territorial composta pela própria Grécia, com o Épiro, a Macedônia e a Trácia, mas também por toda a região da Ásia (continente) que teria sido colocada sob o domínio de Roma, estendendo da Ásia Menor até o rio Tigre. O mesmo mundo grego conta também com a Cirenaica e o Egito. Cf. STE.CROIX, 1987: 8.

${ }^{37}$ Ver, p. ex., Ibidem: 502.

${ }^{38}$ Cf. KEHOE, 2007.
} 
apontar para uma quantidade maciça de trabalho escravo, ainda que toda a península da Anatólia fosse uma grande exportadora de escravos para latifúndios na Itália e na Sicília (MARTIN, 2005: 226). Sartre defende um quadro no qual os escravos têm pouca parte no trabalho das grandes propriedades em comparação com arrendatários e trabalhadores assalariados (SARTRE, 1991: 264). No entanto, o próprio historiador destaca as dificuldades em se traçar um quadro do trabalho rural na Ásia Menor como um todo:

Les textes s'intéressent davantage à ceux qui possèdent qu'à ceux qui travaillent la terre. Malgré la multiplication des inscriptions en provenance des campagnes, modes d'exploitation et main-d'oeuvre restent mal connus. Ainsi, à la question « qui travaille la terre ? », on se trouve embarassé pour répondre ; on peut avancer qu'il y a des esclaves et des paysans libres, petits propriétaires ou non, mais les textes mentionnent aussi des groupes de villageois aux noms divers (katoikoi, paroikoi, hiérodouloi, hiéroi) dont nous ne connaissons pas le statut exact. (Ibidem: 263).

Havia, porém, outros meios de se acumular riquezas, principalmente no âmbito urbano das bem localizadas cidades da Ásia. No entanto, mesmo no meio urbano a principal fonte de riqueza continuava sendo, de uma forma ou de outra, a proveniente do seu território, a $\chi \omega ́ \rho \alpha$ (Ibidem: 286). Primeiramente, por meio das rendas advindas da própria propriedade da terra, quando essa era cedida para cultivo de arrendatários. Esse é o caso principalmente daquelas grandes propriedades pertencentes aos cidadãos mais ricos da pólis. Em segundo lugar, o artesanato da cidade se fundamenta, em grande parte, naqueles produtos retirados da sua zona rural, como no caso da produção de tecidos de lã e linho. Em terceiro lugar, tem-se a própria exportação, por parte da pólis, de produtos primários retirados do território, sem sua transformação pelo artesanato.

O artesanato constituía uma fatia considerável da economia urbana ${ }^{39}$, principalmente tendo-se em conta a posição estratégica das cidades asiáticas, que lhes reservava mercados em vários pontos do Mediterrâneo oriental, embora não fosse, certamente, a única das atividades econômicas de peso presentes nas pólis. Havia também o comércio, por exemplo, com a posse de navios mercantes, ou também a atividade bancária. Ambas eram profissões normalmente malvistas pelas elites, sendo a agricultura e a renda retirada de propriedades rurais consideradas mais dignas de honra. No entanto,

\footnotetext{
${ }^{39}$ Para mais detalhes acerca da economia urbana nas pólis da Ásia, cf. SARTRE, 1991: 286-291.
} 
garantiam riquezas o suficiente para inclusive levar por vezes libertos ao topo da elite econômica e/ou política da pólis (SARTRE, 1991: 156). Essa seria a "burguesia" cuja existência Rostovtzeff enxergava no Mediterrâneo romano e da qual Finley não conseguia extrair, por meio da documentação, qualquer lógica de empreendimento capitalista. Como já dito acima, porém, a arqueologia tem apresentado cada vez mais um quadro diferente, e o que se aplica no campo pode ser aplicado também à cidade. Não precisamos enxergar na pólis sob domínio romano uma sociedade capitalista, colocando esta classe rica sem status necessário no mesmo patamar da burguesia das cidades europeias da Baixa Idade Média ou daquela mercantil moderna, peça fundamental no funcionamento do Antigo Sistema Colonial. Isso seria, inclusive, um anacronismo considerável. Não poderemos, contudo, adotar também uma visão limitada de que mercadores, banqueiros e outros profissionais do mundo urbano romano (que poderiam não deixar seus empreendimentos presos às cidades, adquirindo também propriedades rurais) se deixavam levar simplesmente por uma lógica cumulativa, como gostaria Finley.

Do mesmo modo, não haveremos de limitar as relações sociais no âmbito urbano a uma lógica de exploração do trabalho de uma classe por outra (se é que podemos falar em classes aqui). Havia espaços de interação para além das relações de trabalho. Uma delas, por exemplo, era o patronato, que gerava compromissos entre um cliente e seu patrono, nos moldes da relação patronal que tinha todos os habitantes do império com a beneficência do príncipe. Tal relação patronal poderia se dar de forma deliberada ou não. Deste modo, determinada pessoa poderia se colocar na posição de cliente de outrem nos casos de necessidade, como na carestia, ou com o objetivo de ascensão social, quando se dirigia a uma personalidade notável de alto status social, que poderia fornecer-lhe o caminho e os meios para alcançar suas ambições. Poderia ocorrer, porém, de uma pessoa ser colocada pela lei em tal posição, tal como quando um escravo era libertado por seu senhor, estando este último ainda vivo (ou seja, uma libertação sem ser por testamento). O liberto deveria guardar relações de respeito filial com seu antigo mestre até a morte do mesmo.

Outra forma de interação social entre pessoas de condições econômicas e sociais diferentes na pólis era o que alguns estudiosos chamam de "associações voluntárias", um conceito que visa abranger uma forma de organização sócio-cultural conhecida no mundo de língua latina (especialmente Roma, claro) como collegia. No Mediterrâneo oriental, onde, ao menos nos centros urbanos, predominava a língua grega, estes agrupamentos

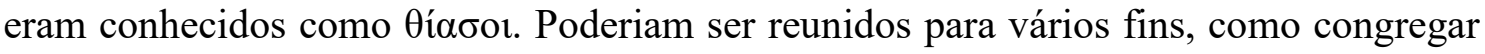


membros de uma mesma profissão (neste caso havendo uma relativa isonomia social interna ao grupo), mas também, por exemplo, para reunir adoradores devotos de alguma divindade estrangeira à cidade que tivesse ou não um templo local próprio. Do mesmo modo, havia a possibilidade de tais associações se constituírem de modo a servir como um grupo adepto de uma determinada escola filosófica ou de algum filósofo popular. Em suma, as razões para se constituírem associações voluntárias eram as mais variadas. Interessa-nos, porém, particularmente a interação social envolvida aí, principalmente porque os membros de um grupo como esse não necessitavam pertencer ao mesmo status ou classe social. Era comum, desta forma, que adeptos ricos exercessem o patronato inclusive neste ambiente social de uma série de maneiras diferentes, como sustentando questões materiais envolvidas nas reuniões (principalmente no caso de haver uma prática de fazer uma ceia ritual, o que era deveras comum) ou mesmo conferindo o espaço para as reuniões, concedendo sua própria casa para tal fim ${ }^{40}$.

Neste ponto, porém, aproximamo-nos demais da questão da religião nas pólis da Ásia, que é discutida de forma particular na próxima sessão. Convém, contudo, que façamos um arremate da presente narrativa, exercitando uma visão geral sobre esta região do Império Romano no qual se difunde e desenvolve o cristianismo com rapidez e organização consideráveis. Estamos tratando aqui não apenas de uma província rica do Mediterrâneo sob domínio de Roma, mas de uma região que está no auge de sua prosperidade econômica. Quando Paulo põe seus pés na Ásia pela primeira vez, no início de uma estadia de pelo menos dois anos em Éfeso, praticamente todas as cidades da província já se encontravam em uma ascendente econômica que recebera um bom impulso do poder imperial, especialmente a partir do governo de Augusto. Quando Inácio de Antioquia passa acorrentado por Esmirna, esperando para embarcar rumo a seu aguardado e desejado destino em Roma, a província asiática encontra-se no seu apogeu econômico e político, de modo que não é de impressionar que tenha se dedicado a comunicar-se com os cristãos da região, mesmo em condições severamente adversas. A riqueza local nesta época, agora impulsionada de forma especial pela abertura de novos mercados a oeste e a leste, confere o destaque para as elites locais, das quais são recrutados mais e mais membros para o centro imperial, seja por meio de nomeação para participação na administração central, seja na entrada para uma das maiores honras que podem ser alcançadas por um cidadão romano (que proliferam na região neste período):

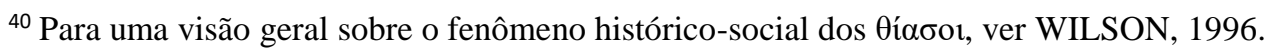


a ordem senatorial. Consequência deste novo momento de sublimação das elites locais aliadas a Roma é a ação das mesmas no espaço público da pólis, algo esperado como natural: quem tem mais, deve fazer mais pela coletividade. E pelos deuses.

\section{3: A religião na Ásia}

Certamente é de conhecimento da maior parte dos antiquistas que os cristãos, em seus primeiros séculos de existência, eram com frequência alcunhados negativamente como sendo "ateus", isto é, homens e mulheres que não demonstravam piedade para com os deuses, preferindo, por outro lado, manterem-se na prática de sua superstitio. Deste modo, por exemplo, segundo o Martírio de Policarpo de Esmirna, escrito em meados do século II d.C., o bispo bem-aventurado é instigado pelo procurador romano da Ásia a rejeitar suas crenças, declarando publicamente no meio da arena: "Morte aos ateus!" A este requerimento, contudo, Policarpo não demonstra qualquer rejeição ou hesitação, virando-se para a plateia eufórica e gritando as palavras ordenadas $(9,2)$.

Por que isso? O que significava ser "ateu" nas cidades da Ásia? Por quais deuses estes cristãos demonstrariam tão pouco respeito a ponto de atrair para si a desconfiança pública, frequentemente até mais que a das próprias autoridades? Como eles sugeriam ou mesmo demonstravam seu desprezo pelos mesmos deuses, aos olhos do povo pelo menos? Para aproximarmo-nos das respostas a estas perguntas, precisamos primeiro considerar o que era ser uma pessoa piedosa na Ásia romana dos séculos I e II d.C., assim como quais eram as práticas piedosas que eram permitidas ou mesmo incentivadas pela coletividade e/ou pelo poder romano.

\subsection{1: Os cultos das cidades e da província ${ }^{41}$}

No período que estudamos, as cidades possuíam seus cultos próprios. Isto significa que alguns cultos não eram considerados uma mera questão privada do indivíduo, mas, muito pelo contrário, constituíam uma manifestação coletiva de piedade para com os deuses. A falta contra tal piedade poderia acarretar sérias consequências para

\footnotetext{
${ }^{41}$ Certamente aqui não pretendemos fazer uma narrativa dando conta de todos os cultos de cada cidade, sendo mesmo alguns cultos de maior vulto não abrangidos, o que não significa que sejam menos importantes no contexto geral. Os exemplos que serão citados, portanto, terão caráter meramente representativo, não sendo necessariamente considerados mais relevantes ou com difusão maior do que, por exemplo, os oráculos de Apolo e os cultos a Cibele e a Ísis.
} 
a pólis como um todo. Não havia separação entre as esferas civil e religiosa, como vemos pela presença de altares e templos em fóruns e ágoras. Muitos momentos da vida pública da cidade eram marcados por preces e sacrifícios ao deus ou aos deuses especialmente adorados no ambiente urbano.

Por outro lado, o culto ao deus de uma determinada cidade poderia tomar uma proporção tal a ponto de extrapolar os limites da própria pólis e tornar-se um culto valorizado não apenas pelas cidades da mesma região ou província, como também por gentes de várias regiões do Mediterrâneo. Era o caso, por exemplo, do grandioso templo da Ártemis Efésia, um culto antigo provavelmente dissociado de outros cultos a Ártemis do mundo de língua grega ${ }^{42}$, mas que, no período que estudamos, atraía peregrinos da Ásia e de várias outras províncias do império, sendo mesmo uma das principais fontes de riqueza da cidade (TREBILCO, 2004: 20). Em Pérgamo, por outro lado, havia o grande templo dedicado a Asclépio, o Asclepieion, especialmente valorizado por habitantes de todo o império por conta de seus rituais medicinais. A ele Élio Aristides, proveniente de Esmirna, dedicou uma série de poemas após seu colapso em Roma (ocorrida em 144 d.C.), para serem cantados por garotos provavelmente no pequeno teatro anexo ao Asclepieion (BOWIE, 2000: 915). Podemos sugerir que esses seriam os principais cultos que fariam da província da Ásia Proconsular um dos principais pólos religiosos do Mediterrâneo romano, competindo com outras localidades de particular relevância como Elêusis (com seus mistérios), Delfos (com seu famoso oráculo de Apolo), Alexandria (com o principal templo dedicado a Serápis) e Jerusalém (que guardava o Templo dos judeus).

Os cultos citados, contudo, podem ser classificados como os tradicionais das respectivas localidades, ou seja, estavam especialmente imbricados na própria identidade de suas cidades desde tempos muito anteriores ao que nos focamos, sem alterações drásticas durante o novo período romano (BEARD, NORTH E PRICE, 1998: 360). Isto não significa, contudo, que as pólis da Ásia não se abrissem para outros cultos, igualmente considerados dignos de honra pública. Podemos citar dois casos aqui para exemplificar

\footnotetext{
${ }^{42}$ É costumeiro se dizer que a Ártemis de Éfeso seria uma deusa ligada a fertilidade, diferente da deusa de mesmo nome cultuada nas cidades gregas, virgem e dedicada à caça. No entanto, Trebilco aponta para a possibilidade de equívoco de tal visão, uma vez que seria fundamentada, sobretudo, em materiais polêmicos cristãos contra a deusa, que tomavam os vários objetos em forma de ovo que a estátua sagrada segurava como sendo seios. No caso de serem seios, a multiplicidade dos mesmos apontaria para uma quase óbvia conexão da deusa com a fertilidade. Cf. TREBILCO, 2004: 22-3.
} 
este ponto: o primeiro é o do culto imperial, já referido brevemente em outro ponto; o segundo é o culto ao deus Serápis, originado em Alexandria.

O caso do culto imperial é digno de nota especial devido à sua relevância no quadro político asiático da primeira metade do século II d.C., nos reinados de Trajano e Adriano, os "filelênicos", tanto nas relações políticas entre a região e centro do poder imperial, como nas entre as próprias cidades. Seguindo uma política iniciada por Augusto, ambos os imperadores deram apoio especial à conservação, manutenção e valorização dos cultos tradicionais da Ásia. As elites de algumas cidades locais, contudo, possuíam uma antiga tendência a estreitar simbolicamente sua aliança com Roma por meio da dedicação de templos ligados ao poder romano. Deste modo, Esmirna possuía um templo dedicado à deusa Roma desde 195 a.C. (BEARD, NORTH E PRICE, 1998: 158). No período que estudamos especificamente, um ponto nodal na rivalidade entre as cidades da região encontra-se em questões relacionadas ao culto imperial da koinon da Ásia, especialmente no que se refere a quais cidades deveriam ser sedes de tal culto (GLEASON, 2006: 230). Isso se mostra patente por meio de um relato feito por Tácito, em seus Anais (4.55-6). Segundo ele, durante o reinado de Tibério, sucessor de Augusto no principado, teria havido uma disputa na Ásia sobre qual cidade teria a honra de construir um novo templo provincial dedicado ao imperador. Em decorrência de tal querela, onze cidades enviaram embaixadas ao imperador para reivindicar sua adequação para ser a sede do novo culto. De início, as cidades de Trália, Hypaepa, Laodicéia e Magnésia foram rejeitadas, consideradas "insignificantes demais". Halicarnasso, por sua parte, era considerada uma forte candidata, com seus defensores apresentando o argumento de que, mesmo as fundações do templo sendo lançadas na rocha, o risco para o mesmo era diminuto, considerando que havia mil e duzentos anos que suas casas não eram sacudidas por um terremoto. Outra forte candidata era Pérgamo, antiga capital do reino atálida, por já possuir um templo dedicado a Augusto e por ele autorizado em 29 a.C.; no entanto, justamente por já possuir tal templo considerou-se que já havia sido suficientemente honrada. Éfeso e Mileto, por sua parte, foram consideradas dedicadas demais aos deuses Ártemis e Apolo, respectivamente, para receberem um novo culto de tal porte e de tamanha importância regional (embora Éfeso viesse de fato a 63epres-lo mais tarde, em 89/90 d.C.). Ilium, afirmando ser, como sucessora de Troia, a pátria-mãe de Roma, não conseguiu sucesso também. A escolha ficou, finalmente, entre Sardes e Esmirna, sendo essa última preferida pelo Senado, dentre outras razões advindas do histórico político entre ela e Roma, por ter sido a primeira cidade da região a dedicar um 
templo à deusa Roma, como já mencionado acima. Ser escolhida para sediar um culto imperial trazia uma série de consequências positivas para uma cidade (TREBILCO, 2004: 16). Para além disso, templos municipais dedicados a Roma e aos imperadores mortos e deificados encontravam-se por todos os lados na Ásia, construídos por pura iniciativa local (Ibidem: 33-5).

Outro culto sem um caráter tradicional e de larga difusão na Ásia era aquele dedicado ao deus Serápis, desenvolvido no Egito helenizado. Apesar de originado e tendo seu templo principal sediado no Egito, Serápis possuía adoradores nas principais cidades asiáticas, com templos dedicados publicamente a ele em Éfeso, Pérgamo e Mileto, todas elas centros urbanos deveras imbricados na rede comercial do Mediterrâneo oriental. Singular no culto a Serápis é o fato de o formato de seu templo divergir com certa frequência daqueles dedicados a deuses de origem grega, sugerindo, por vezes, um espaço fechado para a reunião da assembleia de adoradores, quando no caso dos templos tradicionais da Ásia o recinto coberto e cercado por colunas era reservado à imagem sagrada objeto de culto e aos seus sacerdotes (KOESTER, 2012: 195).

\subsection{2: Cultos privados}

Outra dimensão religiosa que deve ser abordada aqui e que possui particular importância para a pesquisa são aqueles de caráter privado, ou seja, que não possuíam o caráter público de outros cultos, sendo normalmente reservados a grupos relativamente pequenos. Citaremos dois casos que são de interesse especial para nós: o primeiro são as já citadas associações voluntárias; o segundo são os cultos de caráter doméstico.

Como já dito anteriormente, era consideravelmente comum a existência, nos centros urbanos do Império Romano do período que estudamos, de associações de membros voluntários destinadas a fins diversos. Kloppenborg os divide da seguinte maneira (KLOPPENBORG, 1996: 26): as associadas com uma household; aquelas formadas em torno de um comércio ou profissão específicos; e aquelas organizadas com o fim de cultuar um deus ${ }^{43}$. Seja qual fosse o caso, era comum, como também já citado, que tais associações contassem com uma diversidade social considerável em seu interior, como nos casos, por exemplo, em que eram constituídas para reunir adoradores de uma deidade específica de outra região do Mediterrâneo romano. Nesses casos, a participação

\footnotetext{
${ }^{43}$ Cf., também, SARTRE, 1991: 162.
} 
na associação poderia servir para vários fins, conforme a pessoa que se interessasse. Poderia ser um meio de um cidadão rico exercer o patronato, cedendo o espaço e os meios para que as reuniões ocorressem (SARTRE, 1991: 133) ${ }^{44}$, mas poderia também ser uma oportunidade para um membro mais pobre garantir sepulturas dignas para si e para sua família (KLOPPENBORG, 1996: 23-6). A associação servia como um ambiente de estabelecimento de uma série de relações sociais de certa forma paralelos à cidade como um todo, o que é sugerido singularmente pelos títulos conferidos aos administradores, frequentemente inspirados nos dos próprios magistrados da cidade. Neste sentido, por exemplo, Harold Remus apresenta como Élio Aristides utiliza-se, na Ásia do século II d.C., de associações voltadas para o culto do deus curandeiro Asclépio (que, como visto, possuía um grandioso templo em Pérgamo) de modo a estabelecer uma complexa rede de relações em torno de si envolvendo amizades e patronatos (REMUS, 1996: 146-168).

Por vezes ocorria de algumas associações serem vistas com suspeita pela população e/ou pelo poder romano, o que poderia acarretar em medidas drásticas, como no famoso caso dos adoradores de Dioniso na Itália no século I a.C. Esse risco não era corrido unicamente por associações de caráter religioso. Em uma das correspondências entre Plínio o Jovem, então governador da Bitínia, e o imperador Trajano, trata-se do destino de uma associação de combatentes de incêndios em Nicomédia. Apesar de seu óbvio potencial de utilidade pública, Trajano decide por sua dissolução, considerando a possibilidade de as reuniões fechadas do grupo darem abertura a planos de caráter mais subversivo.

Outra forma de culto que pode ser citado, e que por vezes poderia ser confundido com uma associação devido ao ambiente, é o de caráter doméstico. Uma família poderia adotar um culto para si no ambiente privado da household, participando dele os seus membros, o que incluiria os escravos, outros empregados e libertos. No caso de uma família de origem italiana residindo em uma das pólis asiáticas ou em uma colônia romana, tal culto poderia ser o dos lares, os deuses domésticos aos quais eram dedicados ao menos um altar em um recinto especial da casa.

\subsection{3: Comunidades judaicas}

\footnotetext{
44 "The collegium, whether domestic, professional, or cultic, also afforded the elite an opportunity to display largesse in the form of benefactions given to collegia. The collegia involved would then be expected to reciprocate by honouring and, perhaps, more than occasionally, supporting the interests of their patron/a" (KLOPPENBORG, 1996: 27).
} 
Uma comunidade étnico-religiosa de fundamental importância à qual precisamos referir aqui é a judaica. Os judeus encontravam-se dispersos pela maior parte do Mediterrâneo romano, formando comunidades próprias sempre que lhes era permitido fazê-lo pelas autoridades locais ou pelo próprio imperador.

As origens da comunidade judaica na província da Ásia Proconsular são particularmente obscuras, tanto pelas evidências arqueológicas quanto pelas literárias (TREBILCO, 2004: 37). No entanto, se seguirmos o testemunho do historiador judeu Flávio Josefo, que escreve pelo fim do século I d.C., certamente a chegada de judeus ao território que, sob Roma, constituiria a província asiática, se deu antes que o último rei atálida legasse à nova potência mediterrânica o seu território na costa oeste da península da Anatólia. Em Antiguidades Judaicas 12.125-6, Josefo afirma que os judeus que habitavam a Jônia receberam cidadania por parte do rei selêucida Antíoco II (262-246 a.C.). Trebilco nota que, por mais que a notícia a respeito de uma cidadania conferida em tempos tão distantes daqueles do escritor seja de autenticidade duvidosa, o pressuposto de que, à essa época, já havia judeus nessa área mostra-se mais confiável (Ibidem: 38). Por outro lado, uma carta provavelmente autêntica de outro rei selêucida, Antíoco III, a Zeuxis, governador da Lídia (território abrangendo boa parte das cidades mais importantes da futura província da Ásia, como Éfeso, Esmirna e Pérgamo), dá conta de que cerca de duas mil famílias judias deveriam ser realocadas da Babilônia para a Lídia e a Frígia (Antiguidades Judaicas 12: 148-153; cf. TREBILCO, 2004: 38).

Para além da antiguidade da comunidade judaica asiática, alguns outros elementos marcantes da mesma devem ser levantados ${ }^{45}$, por conta de sua alta relevância para a difusão e o desenvolvimento do cristianismo asiático, inclusive no que tange os conflitos internos às comunidades cristãs presentes nas principais cidades da Ásia em seu primeiro século de existência.

Em primeiro lugar, a documentação nos apresenta comunidades judaicas muito organizadas no período em que estudamos, conscientes de si e do papel que poderia ter uma comunidade unida com lideranças próprias para 66epresenta-las perante os oficiais legais da cidade, da província e do império. Tal união garantiu que os judeus asiáticos conservassem sua ligação com o Templo de Jerusalém, na Judeia, por meio de medidas legais que garantissem o seu direito de enviar as taxas devidas ao centro religioso do judaísmo. Do mesmo modo, a comunidade judaica organizada trabalhou para garantir por

\footnotetext{
${ }^{45}$ Para uma maior digressão a respeito de tais elementos, cf. TREBILCO, 2004: 39-43.
} 
parte das autoridades locais o direito de conservar o seu descanso no sétimo dia da semana ${ }^{46}$ e de se reunir para cultuar o seu deus único.

Em segundo lugar, podemos notar um histórico peculiar de conflito e paz entre as comunidades judaicas e as cidades da Ásia nas quais encontravam-se inseridas. A um período considerável de conflitos (em geral refletindo a possível falta de vontade coletiva dos habitantes da pólis para com uma realidade social estranha à vida comum, especialmente no que tange a relação com os deuses, que constituíam parte marcante das identidades locais) abrangendo toda a segunda metade do século I a.C., sucede-se uma era de paz duradoura, na qual os judeus habitantes da Ásia não sofreram grandes moléstias por conta das cidades e, aparentemente, não se envolveram em quaisquer revoltas contra autoridades locais ou imperiais. Em alguns lugares da província, inclusive, o sentimento de integração da comunidade judaica com a cidade parece ter sido especialmente marcante, como no caso de Sardes, onde a sinagoga foi encontrada justaposta a nada menos que o ginásio da pólis. Podemos sugerir, com Trebilco, que, “depois do ano 2 EC, as comunidades judaicas na Ásia Menor, incluindo Éfeso, geralmente viveram pacificamente e interagiram positivamente com suas comunidades maiores, o que era um fator que lhes permitiu florescer e compartilhar da prosperidade da vida urbana na Ásia neste período" (Ibidem: 41).

O terceiro elemento a ser destacado é o tamanho considerável das ditas comunidades, ainda que não seja possível traçar números mais exatos. Podemos notar, contudo, o incômodo das autoridades locais de Éfeso, por exemplo, com as quantias enviadas por judeus como taxas devidas ao Templo de Jerusalém. Também Trebilco nota que tal incômodo faria mais sentido se considerássemos a existência, em Éfeso, de uma comunidade minimamente relevante a ponto de se considerar aviltante que tais somas de dinheiro pudessem fluir livremente da cidade para um templo longínquo sem que nada fosse feito a esse respeito (Idem). Do mesmo modo, a já citada sinagoga de Sardes possuía espaço suficiente para acomodar mais ou menos mil pessoas (Ibidem: 50).

Em quarto e último lugar podemos citar o apoio dado pelas autoridades romanas às comunidades judaicas da Ásia, especialmente à de Éfeso. Em Antiguidades Judaicas 14.262-4, por exemplo, Flávio Josefo relata como um decreto da assembleia de Éfeso deixa transparecer tal apoio, quando os judeus da cidade recorreram ao procônsul para

\footnotetext{
46 "These factors - comunal life and the right of assembly, the temple tax and the link with Jerusalem, observing the Torah including food laws and the Sabbath - show that the Jewish community in Ephesus maintained significant facets of Jewish identity" (TREBILCO, 2004: 40).
} 
garantir seu direito de guardar o sábado sem serem por isso prejudicados, o que lhes foi prontamente concedido. No decreto, encontra-se dito que a questão da observância do sábado pelos judeus "concerne aos romanos", ou seja, é uma medida por parte de Roma que deve ser observada, independente do que pense a assembleia popular local. Um ponto vital da identidade e do cotidiano dos judeus, portanto, se sustentava sobre um precioso e silenciador apoio romano.

\section{4: Cristianismo asiático e Mediterrâneo}

Quando o cristianismo chegou à província da Ásia Proconsular, uma série de fatores históricos encontravam-se pressupostos. O principal deles, a integração política e econômica do Mediterrâneo foi um processo que durou séculos até encontrar seu apogeu justamente no período aqui estudado. Sem tal integração, seria bem mais difícil imaginar como uma nova fé gerada nos rincões de uma zona periférica no sistema políticoeconômico mediterrânico antigo poderia alcançar tão rapidamente áreas tão vastas do Império Romano. Apesar do esforço incansável de Paulo nesse sentido ser admirável, certamente não teria o mesmo efeito se ele não tivesse um império mediterrânico altamente conectado à sua disposição. A conectividade estava na alma do próprio movimento cristão antigo, e Inácio de Antioquia é um símbolo do compasso entre os universalismos cristão e romano: enquanto o supervisor cristão era levado prisioneiro por um império que se gabava de ter um domínio abrangendo um território que lhe permitia fazer seu transporte até a capital romana, o mesmo Inácio se utilizava sua viagem final para reafirmar a unidade interna das igrejas com as quais se comunicava, assim como a harmonia das várias comunidades urbanas entre si.

$\mathrm{Na}$ Ásia, em particular, a proximidade secular entre as cidades da costa ocidental da Anatólia, incentivada por rotas comerciais, organizações político-religiosas e sua reunião sob uma mesma unidade administrativa por formas de autoridade superiores (Reino Atálida e Império Romano), parece ter garantido tanto uma rápida difusão do cristianismo entre seus principais centros urbanos ainda no primeiro século depois de Cristo (como pode ser visto no capítulo 2), quanto uma grande conectividade entre as igrejas locais (cujo caso da comunicação de Inácio, analisado no capítulo 3, serve de bom exemplo). Muito provavelmente, esse pode ser considerado um dos principais fatores para que o cristianismo asiático ganhasse certo destaque na virada dos séculos I e II d.C., 
justamente no período em que a região se encontrava em franca ascensão política e econômica.

Por outro lado, o cristianismo recém-fundado encontraria concorrentes de peso e de longa data estabelecidos na Ásia. A começar pelos próprios cultos públicos: os templos de Ártemis em Éfeso e de Asclépio em Pérgamo são apenas alguns exemplos de cultos cívicos altamente populares, que possuíam peso tanto para as identidades locais quanto para o seu ordenamento político-econômico. Apesar de os escritores cristãos antigos raramente demonstrarem alguma perspectiva de substituir a religião oficial pelo culto a Cristo, não era ignorado, por nenhuma das partes, os riscos inerentes à adoração monoteísta em caráter universal pregada pelo cristianismo para a ordem político-religiosa vigente, mesmo que os primeiros grupos cristãos pudessem se organizar de forma semelhante a cultos privados e/ou diaspóricos, como as associações voluntárias e as sinagogas. Ao invés, embora não fosse uma constante, a desconfiança pública com relação a tais grupos não era uma raridade. Para sobreviver e se desenvolver em tal ambiente, as primeiras igrejas asiáticas precisariam de um forte fator de coesão interna que lhes permitisse tanto enfrentar o desafio de uma hostilidade pública intermitente quanto cumprir seu ímpeto expansivo e proselitista inicial. 


\section{Capítulo 2 - $O$ cristianismo asiático e suas lideranças, de sua fundação a 100 d.C.}

Por volta do ano 30 d.C., deu-se na Judeia um evento, um tanto corriqueiro no Império Romano, que passou completamente despercebido por parte dos habitantes das cidades da Ásia Proconsular: um carismático profeta judeu, aclamado por seus seguidores como sendo o esperado rei e libertador escatológico de Israel, foi preso e condenado à morte por crucifixão como um rebelde contra a ordem romana. Em tese o movimento iniciado por ele deveria ter morrido crucificado junto, do mesmo modo que ocorrera em tantos outros casos, como é lembrado pelo autor dos Atos dos Apóstolos por meio da boca do famoso mestre judeu Gamaliel (Atos 5,34-39) ${ }^{47}$. Não foi isso, como se sabe, o que ocorreu. Os discípulos mais próximos do profeta passaram a pregar que o mesmo teria ressuscitado, mixando a pregação de seu mestre a respeito da chegada próxima do reino escatológico de Deus com uma mensagem focada no próprio mestre, do qual se esperava uma nova vinda próxima para concretizar a vitória final de Israel ${ }^{48}$. Seria o fim, então, de outro império, por vezes encarado também de modo escatológico por muitos escritores da época, a saber, aquele descrito no capítulo 1, envolvendo uma série de centros urbanos em aliança com uma pólis central: Roma.

Seria essa uma resposta direta aos anseios de Roma de ser o elemento final de integração do Mediterrâneo e de suas periferias, o "mundo conhecido"? Não se sabe ao certo, embora deva-se notar que o movimento dos seguidores de Jesus possuía poucos

\footnotetext{
${ }^{47}$ Optei deliberadamente por realçar o papel do autor dos Atos dos Apóstolos na composição do discurso atribuído a Gamaliel por dois motivos: 1) Marguerat demonstrou em seu estudo que o que hoje conhecemos como Atos dos Apóstolos seria, originalmente, uma obra que visava esgueirar-se pelas regras de composição histórica comuns à sua época, sendo uma de suas características a reprodução livre por parte do autor de discursos atribuídos a personagens da narrativa, ainda que fosse igualmente importante o ditame de que o mesmo autor deveria se esforçar ao máximo para se aproximar do que teria sido o discurso real (MARGUERAT, 2003: 28-30); 2) Há uma variedade de posicionamentos acadêmicos relativos à historicidade do discurso e daquele que o enuncia. Dillon não a defende, mas também não a condena, observando que "historicamente factual é ao menos a trajetória de Gamaliel - 'o Ancião' e descendente do grande Hillel - que, certamente, foi um erudito judeu muito respeitado em Jerusalém no período de 25-50 d.C." (DILLON, 2011: 342). Murphy-O'Connor também parece presumi-la (MURPHY-0'CONNOR, 2013: 38). Brown anota apenas a existência de um debate "interminável" a esse respeito, embora note alguns anacronismos no discurso, como no caso da referência à revolta de Teudas, que teria ocorrido após o período ao qual a narrativa se refere (BROWN, 1997: 292). Para um breve sumário sobre a carreira de Gamaliel I, cf. VERMES, 2008: 124.

${ }^{48}$ Para um estudo aprofundado e eruditíssimo acerca da pregação cristã mais antiga sobre Jesus e o culto ao mesmo no interior das primeiras comunidades cristãs da Judeia, cf. HURTADO, 2012: 215-291. Hurtado se opõe a uma visão bastante difundida na academia de que, no cristianismo palestino do século I d.C., Jesus teria sido visto e tratado pelos grupos de seus seguidores apenas como um profeta e Messias aguardado, sem qualquer culto voltado para sua pessoa, visão essa que teria sido mantida pelos ebionitas, grupo cristão inicialmente tolerado pela ortodoxia nascente e depois, principalmente a partir do século IV, considerado herético (cf. HÄKKINEN, 2008). Para uma visão clássica a respeito do cristianismo judaico, cf. SIMON, 1986: 237-270.
} 
anseios universalistas de início. Seguindo tal tendência, podemos dizer que dificilmente os discípulos do crucificado poderiam influir no destino do resto do império, da Ásia Proconsular inclusive. No entanto, apenas algumas décadas após a execução brutal de Jesus, seu nome já era pregado na dita província, já influindo de alguma forma, ainda que minimamente, no cotidiano das pólis. Nesse tempo, o mestre já era tomado por uma corrente de seus seguidores como não mais apenas o esperado rei de Israel, mas também como o "Senhor" ( $\kappa u ́ \rho ı \varsigma)$, o filho do próprio Deus único adorado pelos judeus, com pretensões bem mais universalistas que aquelas de princípio cultivadas pelos discípulos.

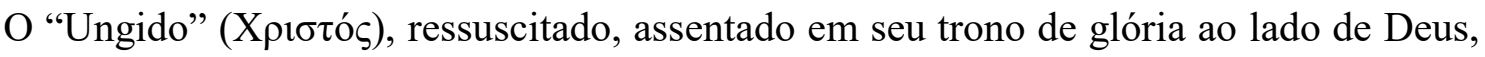
agora imortal e infinitamente poderoso, encontrava-se em ligeira vantagem frente ao seu contraposto terreno, que o havia indiretamente condenado à morte por meio de seu

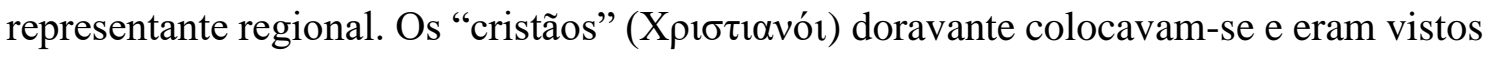
socialmente como seguidores deste "ungido" executado pelo poder imperial, o que trazia óbvias consequências sociais para os mesmos.

O segundo capítulo destina-se a desenhar um quadro narrativo e explicativo da difusão e organização do nascente movimento cristão naquela província romana que é o foco da pesquisa, a Ásia Proconsular, em seu primeiro século de existência. De fato, quando o cristão Inácio de Antioquia passa como prisioneiro pela mesma região, as comunidades de seguidores de Cristo aí presentes encontravam-se consideravelmente organizadas, com formas de autoridade e liderança internas em pleno desenvolvimento, ainda que não necessariamente consolidadas e aceitas pela maioria dos fieis (TREBILCO, 2004: 682). É necessário, porém, se fazer uma caracterização de tais desenvolvimentos no período anterior à composição do curto epistolário inaciano, principalmente se tivermos em conta que as igrejas da Ásia não contavam menos de um século de existência à essa época. Em outras palavras, os processos sociais envolvidos na fundação, construção e expansão das comunidades cristãs asiáticas na segunda metade do século I d.C. estão intimamente conectados ao fenômeno histórico que é a construção de formas de autoridade visando a manutenção e defesa da unidade das mesmas igrejas por volta da virada dos séculos I e II d.C. Deste modo, o objetivo do segundo capítulo é analisar o desenvolvimento histórico do cristianismo asiático, de modo a fornecer elementos para um estudo das formas de liderança interna nas comunidades asiáticas. Ao fim deste trabalho, o foco volta-se para as próprias lideranças e meios de exercício de autoridade, visando, principalmente, apresentar uma imagem, ainda que embaçada, do que Inácio de Antioquia estava falando quando se referia à obediência necessária que deveria ser 
prestada ao supervisor cristão local, em conjunto com os anciãos e servidores da comunidade, assim como quais questões sociais encontravam-se presumidas em sua comunicação e a quais conflitos poderia fazer referência e mesmo estimular, voluntariamente ou não.

Assim como no caso do capítulo 1, o tema do capítulo 2 se debruçara bastante sobre o debate historiográfico em torno de cada um dos eixos problemáticos a serem tratados (como as rotas de difusão do cristianismo pela Ásia, por exemplo). No entanto, mais do que no caso precedente, a narrativa agora utilizará um número maior de fontes primárias, principalmente daquelas que possuem vínculo direto e explícito com as comunidades cristãs asiáticas, sendo por elas produzidas ou a elas fazendo referência. Deste modo, é necessário um destacamento de quais fontes são utilizadas e analisadas e quais são os problemas metodológicos envolvendo tal procedimento, principalmente no caso de fontes que possuem gênero bem diverso característico de uma comunicação direta entre partes, o epistolar, ao qual pertence a documentação inaciana. A necessidade de uma apresentação e escolha bem detalhada e justificada das fontes analisadas, do mesmo modo que como tal análise deve ser feita, se deve, sobretudo, à escassez acentuada de documentos disponíveis relativos ao cristianismo do primeiro século; como consequência, o uso ou não de uma fonte possui um peso gigantesco para a narrativa, principalmente se levarmos em conta que poucos documentos cristãos mais antigos referem (como o faz Inácio) seu local de origem e as circunstâncias de sua composição. A escolha por algumas fontes e a relativização da relevância de outras, portanto, influem diretamente no resultado da análise.

\section{1: Fontes}

A ausência de inscrições e dados arqueológicos seguramente identificáveis e com possível conexão com as primeiras comunidades cristãs da Ásia no primeiro século d.C. obriga-nos a optar pelo uso de fontes literárias, que, ainda que não tão abundantes quando comparadas com outros agrupamentos políticos e sociais do Império Romano (como, por exemplo, o extenso epistolário de Plínio o Jovem, governador da Bitínia no começo do século II d.C.), podem ser consideradas significativas como fontes que não emanam necessariamente de grupos pertencentes aos estratos mais altos da sociedade urbana e imperial, mas que têm origem em grupos sociais com pouco status a ser ostentado (o que se manifesta particularmente em escritos com grego pouco rebuscado, como o Apocalipse 
de João e o Evangelho de Mateus, por exemplo). No entanto, as cidades da Ásia não foram as únicas a serem alcançadas pelos pregadores cristãos, de modo que não são as únicas a estarem diretamente conectadas à produção ou destinação de documentação cristã no

período. É preciso, portanto, fazer antes de tudo um cotejamento destas fontes, apontando quais são as mais interessantes e relevantes para pesquisa. Isso não quer dizer, porém, que fontes cristãs vinculadas a outros centros urbanos do império serão desprezadas. Ao invés, todas elas terão alguma importância, principalmente quando for necessário lançar mão da comparação entre casos de modo a iluminar as especificidades do processo social que é a fundação e difusão do cristianismo pela Ásia Proconsular. Quanto às fontes não-cristãs que venham a ser citadas, uma vez que, em geral, não trazem consigo problemas metodológicos tão prementes para a pesquisa (como o uso tradicional por parte de um grupo religioso, como no caso dos escritos neotestamentários, por exemplo), não serão tratadas de forma particular aqui, com eventuais observações específicas a seu respeito sendo feitas em notas de rodapé.

\subsection{1: O epistolário paulino}

Paulo de Tarso, um dos principais personagens históricos do cristianismo dos primórdios, está intimamente ligado à fundação de igrejas cristãs nas cidades da Ásia, especialmente quando de sua estadia prolongada (pouco mais de dois anos, se nos fiarmos pelos Atos dos Apóstolos; cf. Atos 19,10) em Éfeso em meados do século I d.C. O

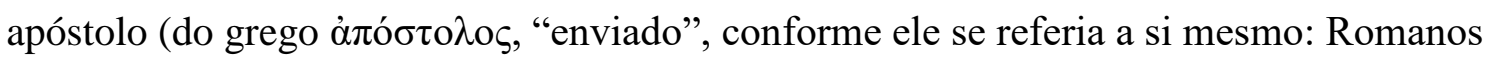
1,1; 1Coríntios 1,1; Gálatas 1,1) é o maior responsável pela produção de escritos posteriormente incluídos no cânon do Novo Testamento: sete cartas seguramente saídas de sua mão ou por ele ditadas encontram-se preservadas, consideradas como escritos sagrados por quase todas as denominações cristãs que viriam a se desenvolver posteriormente $^{49}$. As palavras de Raymond E. Brown devem bastar para deixar clara a importância de Paulo tanto como agente do desenvolvimento e expansão do cristianismo

\footnotetext{
${ }^{49}$ Expressa-o bem Maurice Carrez: "A pessoa e a obra do apóstolo Paulo são de grande interesse. Isso se deve antes de tudo ao fato de o conjunto das epístolas atribuídas a ele constituírem o bloco literário mais importante do Novo Testamento, cerca de um quarto!” (CARREZ, 2008: 9). Seria um tanto quanto desnecessário discutir a autenticidade das ditas sete cartas, uma vez que ela é universalmente aceita pelos estudiosos (são elas: Romanos, Gálatas, 1 e 2 Coríntios, 1 Tessalonicenses, Filipenses e Filêmon). Deste modo, optarei por discutir os casos daquelas que tem em sua autenticidade um objeto de dúvida e discussão por parte da academia.
} 
(inclusive servindo claramente de forte inspiração para nossa fonte principal, Inácio de Antioquia) quanto como fonte para o período:

No other follower of Jesus in NT [New Testament] times left behind a written testimony comparable to that of Paul. True, Luke-Acts (ca. 37,800 words) is longer than the thirteen letters attributed to Paul (32,350 words); but we scarcely know the Lucan author, whereas Paul's personality stands out in his letters. [...] In the whole library of Christianity it is hard to match his impassioned eloquence. (BROWN, 1997: 451)

No entanto, nenhuma epístola sequer foi composta para a comunidade presente na capital da Ásia ou para quaisquer outras em cidades importantes da província, como Pérgamo e Esmirna ${ }^{50}$. Na verdade, a única delas destinada para um público residente na Ásia Menor é aquela "aos gálatas" "51, um termo genérico que se refere a uma região específica da área central da Anatólia mas que não faz referência a nenhum agrupamento urbano em particular. De qualquer forma, essa região encontra-se fora dos limites da província da Ásia Proconsular.

Existe sim uma carta que afirma partir do apóstolo e que a tradição cristã passou para a frente como sendo "aos efésios" (que chamamos aqui simplesmente de "Efésios"), obra do "mais talentoso dos discípulos escritores paulinos" (BROWN, 1997: 454). Há, contudo, uma série de problemas conectados a tal carta, para começar com a autoria: existe uma série de características de Efésios que os estudiosos levantaram e apontaram como não condizentes com uma autoria paulina, dentre elas a teologia do autor ${ }^{52}$ (embora isso não queira dizer tanto quanto esperariam alguns, uma vez que é sabido que Paulo poderia ser bem versátil teologicamente quando considerava conveniente) e o vocabulário por ele utilizado ${ }^{53}$. Ainda que considerássemos Efésios como uma carta escrita

\footnotetext{
${ }^{50}$ Trebilco praticamente lamenta a inexistência de uma carta de Paulo dirigida a Éfeso: "When we compare the few verses that give us some information with our sources for Paul's relationship to, for example, the church at Corinth, we realise how much we are hindered by the lack of a letter written by Paul to Ephesian Christians" (TREBILCO, 2004: 99-100).

${ }^{51}$ Para uma boa e recente análise de Gálatas no que tange as tensões relativas a fronteiras étnicas e as estratégias discursivas e teológicas adotadas por Paulo em sua carta para driblá-las, ver IZIDORO, 2013.

${ }^{52}$ Para uma síntese das diferenças teológicas entre Efésios e as cartas universalmente aceitas como paulinas, ver KOBELSKI, 2011: 618-619. Kümmel faz uma apresentação um pouco mais pormenorizada dos argumentos contra uma autoria paulina no que tange a teologia; cf. KÜMMEL, 2004: 471-476. Uma contra argumentação no âmbito da teologia comparada foi lançada por Markus Barth em seu comentário à epístola (BARTH, 2008: 41-50).

${ }^{53}$ Kobelski (KOBELSKI, 2011: 618) nota que a frequência de hápax legomena (isto é, termos que ocorrem uma única vez em um documento quando comparado com o resto de uma coleção de escritos, como no caso das cartas paulinas) em Efésios não difere muito do que ocorre com as cartas consideradas de autoria
} 
diretamente por Paulo (o que não faremos, incluindo-a no grupo de cartas que reclamam a autoria paulina após a morte do apóstolo, chamadas comumente "deuteropaulinas"), aparentemente o material sequer era relacionado originalmente a Éfeso, uma vez que o trecho onde o destinatário é inserido nas versões modernas não se encontra nos melhores manuscritos ${ }^{54}$.

Uma carta que se afirma paulina, no entanto, direta e explicitamente destinada a uma comunidade cristã asiática é aquela conhecida como "aos colossenses" (doravante referida apenas como "Colossenses"), da qual Efésios aparenta depender muito (KOBELSKI, 2011: 619; KÜMMEL, 2004: 469-471). Ela é um caso especial na coletânea paulina. De fato, ela é a única carta que deixa os estudiosos consideravelmente divididos quanto à sua autoria. Embora a maioria dos pesquisadores da área de Novo Testamento e cristianismo primitivo prefira considerá-la uma obra deuteropaulina (ou seja, escrita por um discípulo e/ou admirador de Paulo após a sua morte e reclamando a autoridade do mesmo), esta maioria não é esmagadora como no caso das chamadas “Cartas Pastorais”, que veremos mais à frente. Apenas para se ter uma ideia, em 1984, Raymond E. Brown afirmava que apenas cerca de $60 \%$ dos estudiosos do Novo Testamento defendiam uma autoria não-paulina para Colossenses, enquanto cerca de $90 \%$ eram a favor de tal tese para as Cartas Pastorais, e 80\% para Efésios (BROWN, 1984: 47). Não houve alterações expressivas de tal quadro desde então (MITCHELL, 2006: 183). Ou seja, por mais que existam questões referentes à linguagem, ao vocabulário e à teologia do autor (HORGAN, 2011: 606-7; KÜMMEL, 2004: 444-453) ${ }^{55}$, muitos

paulina. O que chama atenção é a forma como a carta utiliza outros termos gregos: "Mais significativos são termos como ta epourania, 'nos céus' ou 'lugares celestiais' $(1,3.20 ; 2,6 ; 3,10 ; 6,12)$, ao lado do termo mais usualmente paulino como hoi ouranoi, 'céus'; diabolôs, 'diabo' (4,27; 6,11), no lugar do paulino satanás; palavras que ocorrem nos escritos tardios do NT e nos primeiros padres da igreja [sic]; e palavras como mystérion[sic], oikonomia e plêrôma que aparecem com significados diferentes dos das cartas indiscutivelmente paulinas". Do mesmo modo, Kobelski aponta para o fato de nenhuma das cartas indiscutivelmente paulinas ser marcada por períodos longos e complexos (como nos casos de Efésios 1,3$4.15-23 ; 2,1-7 ; 3,1-9 ; 4,1-6 ; 5,7-13)$, assim como pela abundância de orações adjetivas entrelaçadas e construções participiais ( $p$. ex., 1,3-14; 2,1-7), e pela junção de sinônimos com o caso genitivo $(1,5 ; 6,10)$. Para uma visão semelhante e, ao mesmo tempo, independente, ver KÜMMEL, 2004: 468-469).

${ }^{54}$ Dentre os manuscritos nos quais os destinatários "que estão em Éfeso" não se encontram inseridos estão o Papiro 46 (a versão mais antiga de Efésios) e os originais dos códices Vaticano e Sinaítico, do século IV. ${ }^{55}$ Vale a pena inserir a síntese perfeita que faz Koester dos problemas quanto a uma identificação de Colossenses como sendo de autoria paulina: "A carta contém um grande número de palavras que não ocorrem em nenhuma das cartas certamente autênticas de Paulo (um total de 48; dessas, 33 são hapax legomena, palavras que não ocorrem em nenhum outro lugar do Novo Testamento). O estilo do autor de Colossenses difere marcantemente do estilo de Paulo. Há longas sequências de construções genitivas, como 'reino do filho do seu amor' ( $\mathrm{Cl} 1,13)$, 'a palavra da verdade do evangelho que chegou até vós' $(1,5-6)$, 'desvestimento da natureza carnal' $(2,11)$. O autor gosta de combinar termos paralelos: 'produzindo frutos e crescendo' $(1,6)$, 'orações e pedidos' $(1,9)$, 'constância e longanimidade' $(1,11)$. Ele também constrói 
estudiosos optam por inseri-la no grupo das cartas autênticas do apóstolo ${ }^{56}$. Neste caso, teríamos a única carta de Paulo dirigida a uma comunidade cristã da província da Ásia Proconsular, da qual, inclusive, pouco se ouve a respeito nos dois séculos seguintes. Devido à divisão acadêmica referente a Colossenses e à complexidade de tal debate, demasiado extenso e fundamentado em minúcias para ser inserido na dissertação, evitaremos a presunção de assumir uma posição final a respeito. Deste modo, seguiremos a princípio (e como a maioria da historiografia a ser citada aqui) a posição majoritária, tomando Colossenses como uma carta pseudopaulina; não descuidaremos, contudo, de levantar as implicações de sua possível autenticidade para os debates que serão abordados.

Tratando ainda da igreja cristã de Colossas, podemos destacar uma carta tão pequena quanto notável e da qual praticamente ninguém nega a autoria paulina: aquela dirigida não a uma comunidade, mas a uma pessoa em particular, Filêmon. Esta carta é única por uma série de razões: é a única carta indiscutivelmente escrita por Paulo ("somente uma crítica tendenciosa poderia duvidar da autenticidade desta carta"; KÜMMEL, 2004: 458) dirigida a um indivíduo específico; é a menor de todas as cartas do apóstolo; possui um caráter marcadamente pessoal, sendo um exemplo primoroso não apenas de correspondência cristã, como também de comunicação epistolar entre indivíduos comuns (ou seja, de pessoas não vinculadas explicitamente aos aparatos administrativos, tanto a nível regional quanto ao imperial) no Império Romano ${ }^{57}$; e, de particular interesse para nós, é a única enviada a um destinatário residente em uma cidade da Ásia. Embora tão pequena, portanto, esta carta tem um valor inestimável para a exposição feita no capítulo 2 .

Deste modo, encontramo-nos um tanto quanto deficientes no que tange fontes relativas às comunidades cristãs asiáticas à época do início da cristianização da região, ou seja, quando da pregação de Paulo em Éfeso. Isso não significa que estejamos completamente desprovidos. Paul Trebilco consegue contornar tal limitação (TREBILCO, 2004: 53-103) extraindo pequenas informações que Paulo dá de sua estadia

períodos longos, difíceis de compreender (o parágrafo 1,9-20 é um único período!)" (KOESTER, 2012: 283).

${ }^{56}$ Entre os defensores de peso da autoria paulina de Colossenses, podemos citar MOFFAT: 1918, 153-8; DANIÉLOU, 1968: 59 (embora ele defendesse a autoria paulina para todo o corpus que leva o seu nome, excetuando a Carta aos Hebreus); e BARTH e BLANKE, 2005.

57 "A epístola, que de todas as epístolas de Paulo é a que mais se aproxima da forma das antigas cartas privadas, revela, em seus traços pessoais, características de autêntica veracidade em face da vida real" (KÜMMEL, 2004: 458). 
em Éfeso e da comunidade cristã aí fundada há pouco tempo, principalmente a partir da primeira carta do apóstolo dirigida à igreja de Corinto (à qual nos referimos como 1Coríntios), que foi escrita precisamente na metrópole da Ásia (cf. 1Coríntios 16,8). Igualmente válida, neste caso, é a utilização da comparação da informação que puder ser recolhida com os casos de outras igrejas às quais Paulo se dirige, como a de Corinto, a de Filipos e a de Roma (embora essa última não tenha sido fundada pelo próprio apóstolo).

Alguns estudiosos chegaram a sugerir que o capítulo 16 da carta de Paulo aos cristãos romanos (a qual chamaremos apenas Romanos) seria, originalmente, um bilhete

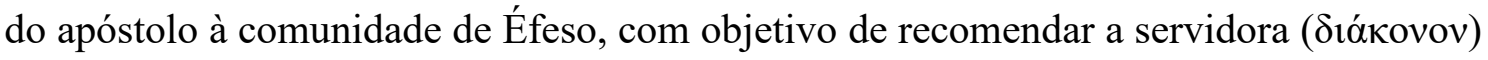
Febe, da igreja de Cencreia (um dos portos de Corinto, na Acaia) e alertar os efésios quanto à atividade dos judaizantes, ou seja, daqueles cristãos que defendiam a necessidade de um não-judeu ser circuncidado antes de ser aceito na comunidade dos discípulos de Jesus (cf. Romanos 16,1-2.17-20). Tal tese se fundamenta, basicamente ${ }^{58}$, no fato de Paulo dirigir-se, em suas saudações, ao casal Prisca e Áquila, junto com "a igreja que se reúne em sua casa" (Romanos 16,3-5), um casal que havia, anteriormente, fixado moradia em Éfeso (1Coríntios 16,19), e a Epêneto, "primícias da Ásia para Cristo" (Romanos 16,5), assim como em uma pressuposta improbabilidade do apóstolo conhecer tantas pessoas em Roma quanto as que elenca no referido trecho. Koester chega a anotar a impossibilidade de uma tal migração em massa de habitantes de Éfeso para Roma, pressupondo, assim, que todos os nomes (ou ao menos a maior parte deles) teriam que ser provenientes da Ásia (KOESTER, 2012: 152-3). A tendência hoje, no entanto, é ver o capítulo 16 como parte integrante da carta original enviada aos romanos, uma vez que se encaixa melhor quando lida em conjunto com o todo do documento (TREBILCO, 2004: $88)^{59}$. Do mesmo modo, não seria difícil conceber que os únicos nomes claramente vinculados à Ásia em outros documentos, ou seja, Prisca, Áquila e Epêneto viessem a se mudar para Roma antes da ocasião da escrita da carta; os Atos dos Apóstolos, inclusive, afirmam que o casal amigo de Paulo era residente na capital imperial antes de se mudarem para Corinto sob Cláudio (cf. Atos 18,2; ver FITZMYER, 2011: 590). Por fim, sabe-se muito pouco sobre a atividade do apóstolo para se afirmar com certeza a impossibilidade

\footnotetext{
${ }^{58}$ Uma boa síntese da tese de que Romanos 16 seria destinado a Éfeso em FITZMYER, 2011: 518.

${ }^{59}$ Como explicar, por exemplo, que em um bilhete repleto de saudações haja uma mudança de tema tão

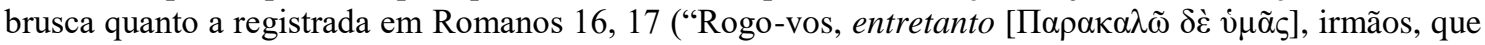
estejais alertas contra os provocadores de dissensões e escândalos contrários ao ensinamento que recebestes")? Mais fácil seria ver em tal trecho uma advertência à qual Paulo se volta ao final de toda a sua dissertação acerca da Lei, tendo em vista os judaizantes que enfrentara durante sua atividade e com os quais se bate em quase todas as suas cartas.
} 
de Paulo conhecer cristãos romanos ou ao menos residentes em Roma à época em que escreve sua $\operatorname{carta}^{60}$. O que é certo e que é claramente visível tanto pelas cartas paulinas quanto pelos Atos dos Apóstolos é que, se existia um aspecto não cultivado pelas comunidades cristãs de meados do século I d.C., esse era a imobilidade. Os cristãos, em geral, já se aproveitavam, e muito, da integração e das redes de comunicação proporcionadas e mantidas pelo Império Romano por todo o Mediterrâneo, a ponto de um apóstolo originário de Tarso e possivelmente formado em Jerusalém planejar seriamente alcançar a Espanha (cf. Romanos 15,28)!

\subsection{2: As cartas pseudopaulinas}

Como já referido acima, as cartas as quais chamamos "pseudopaulinas" são aquelas que teriam sido escritas após a morte do apóstolo Paulo e que se utilizavam do nome do mesmo como autor para conferir mais autoridade para a mensagem a ser transmitida. Aqui, os documentos vinculados de algum modo às comunidades da Ásia são particularmente abundantes.

O caso de Colossenses já foi tratado o bastante: apesar de um número considerável de estudiosos defender uma autoria paulina, iremos prudentemente seguir a maioria, colocando-a a princípio no rol das pseudopaulinas. Também já foram referidos os obstáculos para inserir Efésios dentre as cartas compostas por Paulo, de modo que a podemos inserir também no mesmo grupo. No entanto, cabe a pergunta: o fato de Efésios muito provavelmente não ter sido escrita pelo apóstolo e não ter sido destinada à igreja de Éfeso impossibilita necessariamente sua utilização como documento em nossa pesquisa? A resposta é não, por dois motivos. Em primeiro lugar, tão interessante historicamente quanto a produção de cartas por um apóstolo é a composição de cartas em seu nome após sua partida, o que em si mesma pode ser representativa de um outro fenômeno sociocultural, a saber, a manutenção da figura do apóstolo fundador como autoridade de alguma forma presente na vida comunal de um grupo religioso que já adentrava sua segunda geração de fieis ${ }^{61}$. Nesse sentido, Meeks destaca que a carta

\footnotetext{
60 Uma discussão sumária, porém aprofundada, acerca da integridade de Romanos encontrasse em KÜMMEL, 2004: 408-416.

${ }^{61}$ Raymond E. Brown lembra que os primeiros críticos bíblicos a afirmar o caráter pseudônimo de algumas das cartas do corpus paulino tinham em mente um objetivo fraudulento na composição de tais documentos. A tendência, no entanto, seria, nas últimas décadas, a de se abandonar tal perspectiva no debate, favorecendo a visão de que tais documentos seriam obras de discípulos que se consideravam na autoridade de compor as cartas em nome do apóstolo. A inspiração para tanto seria encontrada em uma série de
} 
apostólica, mesmo que pseudônima, veio a se tornar um dos dois mais importantes gêneros literários do cristianismo em seus primórdios (MEEKS, 2006: 152). Tal perspectiva serve para fundamentar um estudo como o de Raymond E. Brown, por exemplo, que lança mão de vários documentos de provável caráter pseudônimo presentes no cânon do Novo Testamento para fazer a reconstrução de uma série de comunidades da segunda metade do século I d.C., utilizando-se, inclusive, tanto de Efésios quanto de Colossenses (BROWN, 1984: 47-60). Em segundo lugar, ainda que uma destinação geográfica específica não se encontre nos melhores manuscritos antigos, existem indícios de uma conexão de Efésios com o cristianismo asiático, como a grande semelhança de linguagem e temas com Colossenses e a citação, ao fim, de Tíquico, "irmão amado e fiel

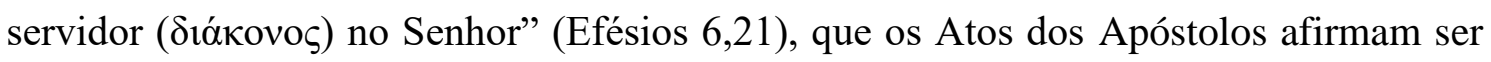
originário da Ásia (Atos 20,4) e que também é citado em Colossenses 4,7-9 como sendo o responsável por levar a carta do apóstolo a Colossas. Deste modo, a origem e/ou destinação asiática da carta apresentam-se como hipóteses bem plausíveis, embora só possamos permanecer no âmbito hipotético ${ }^{62}$. Há inclusive, uma teoria (com não muitas evidências para comprová-la) de que a primeira coleção das cartas ditas paulinas teria ocorrido justamente em Éfeso, com Efésios sendo escrita de modo a encabeçá-la, como uma espécie de síntese de todo o ensinamento de Paulo (KÜMMEL, 2004: 634).

Outras três cartas incluídas dentre as pseudopaulinas são, usual e conjuntamente, chamadas desde o século XVIII de "Cartas Pastorais", devido ao seu enfoque ligeiramente diferenciado se comparado com o resto do epistolário paulino canônico, voltado como é para a vida comunal, com o estabelecimento, por parte de "Paulo", de um corpo de oficiais responsáveis pela administração e guia da igreja (BROWN, 1997: 638-640; KÜMMEL, 2004: 481). Contudo, apesar de o autor identificar-se claramente como sendo o apóstolo Paulo, pelo menos desde o início do século XIX são levantadas dúvidas acerca da autoria

documentos das escrituras hebraicas (ou Antigo Testamento). Cf. BROWN, 1997: 586. No entanto, é necessário termos em conta que, tanto Brown quanto vários dos autores aos quais ele faz referência nesse ponto, são de formação teológica, evidentemente preocupados com os problemas que o possível caráter fraudulento de um documento canônico poderia acarretar em temas teológicos espinhosos, como o da inspiração divina dos livros reunidos no cânon bíblico.

62 Algumas das principais teorias correntes acerca da origem e da localidade da escrita de Efésios envolvem uma origem asiática. Uma delas é de que o endereçamento original do documento seria Laodiceia, o que faria de Efésios a carta à qual faz referência Colossenses 4,16: "Depois que esta carta tiver sido lida entre vós, fazei-a ler também na igreja de Laodiceia. Lede vós também a que escrevi aos de Laodiceia". Os que defendem tal teoria afirmam que ela ajudaria a compreender as claras relações literárias entre Efésios e Colossenses. Outra sustenta que ela seria uma carta circular, a qual Tíquico estava incumbido de levar e apresentar às comunidades urbanas que se encontrassem em seu caminho de Éfeso a Colossas. Ver KÜMMEL, 2004: 463-7. 
paulina desta carta (KOESTER, 2005: 318). Vários argumentos têm sido levantados contra a possibilidade dos documentos terem sido escritos por Paulo, mas os mais convincentes seriam os que seguem (WILD, 2011: 634-5): em primeiro lugar, uma série de termos e sentenças presentes nas ditas Pastorais não se encontram nas cartas universalmente consideradas autênticas (p. ex., " $\pi$ $\sigma \tau$ ò $\varsigma$ ó $\lambda o ́ \gamma o \varsigma$ " ["fiel é a palavra"],

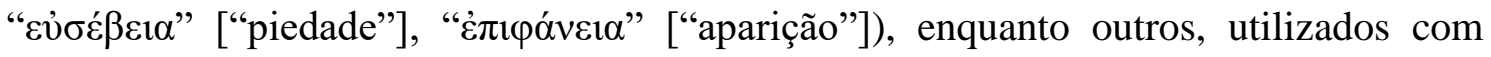
frequência por Paulo, encontram-se totalmente ausentes nas primeiras (p. ex., " $\sigma \tilde{\omega} \mu \alpha$ "

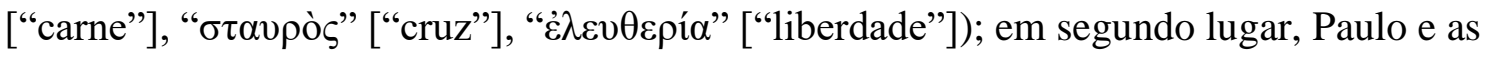
Pastorais divergem no uso de vários advérbios, conjunções e partículas gregas (p. ex., o uso do kaì nas Pastorais difere consideravelmente do uso comum pelo apóstolo); e, em terceiro lugar, e nas palavras de Wild, as Pastorais "apresentam Paulo explicando questões básicas em uma linguagem bastante incisiva a colegas com longo tempo de convivência a quem ele deixou há pouco (1Timóteo 1,3; Tito 1,5) e a quem em breve veria de novo (1Timóteo 3,14; Tito 3,12), um fenômeno que, se de fato, Paulo mesmo fosse o autor, só pode ser chamado de estranho" (WILD, 2011: 635). Com argumentos de tamanho peso, apesar de ainda existirem estudiosos que defendem a autoria paulina (cf. JOHNSON, 2001: 98-9; KNIGHT III, 2013: 51), estaremos fundamentados de forma mais sólida em nossa análise se utilizarmos a Primeira Carta a Timóteo como um escrito pseudoepigráfico. Quanto à datação do documento, considerando uma separação de tempo entre sua escrita e a morte do apóstolo Paulo (à qual faz clara referência a Segunda Carta a Timóteo e que teria ocorrido, segundo a maioria dos estudiosos, na década de 60 do século I), assim como o fato de ela em alguns momentos presumir uma relação aberta entre a comunidade cristã e a pólis (cf. 2,2; 3,7), algo difícil (ainda que não impossível) no período posterior aos ataques promovidos sob Domiciano, faríamos bem em colocar a sua redação em algum momento entre 80 e 100 d.C. (TREBILCO, 2004: 205$)^{63}$.

Sendo compostas enquanto cartas, as Pastorais trazem um tipo de conteúdo que faz com que seu gênero seja frequentemente comparado com o de outros manuais eclesiásticos antigos e que se afirmam de origem apostólica, existentes desde mais ou menos o século I d.C. (como a chamada Didache, ou "Instrução dos Doze Apóstolos") e que se proliferam sobretudo a partir do século III d.C., com a Didascalia Apostolorum e as "Constituições Apostólicas". Alguns, porém, notam que, diferentemente dos ditos documentos, as Pastorais não trazem informações tão detalhadas de como deve funcionar

${ }^{63}$ Uma discussão pormenorizada sobre o problema da autoria das Pastorais encontra-se em KÜMMEL, 2004: 485-507. 
uma igreja em particular, trazendo mais observações pontuais e direções gerais do que um levantamento minucioso de regras (BROWN, 1997: 639). Apesar de serem geralmente analisadas como um conjunto pelos estudiosos, sendo consideradas todas obras de um mesmo autor, existem indícios de que as cartas tratam de situações bem diferentes, assim como não são os mesmos os ambientes envolvidos em cada uma ${ }^{64}$. Das três, duas possuem alguma vinculação com a Ásia pelo conteúdo do texto.

A Primeira Carta a Timóteo (à qual nos referimos como 1Timóteo) se apresenta como uma correspondência do apóstolo Paulo com um de seus colaboradores mais próximos, com instruções de como proceder com a organização da comunidade cristã presente em Éfeso e com a admoestação de alguns, de modo a "não ensinarem outra doutrina” (1Timóteo 1,3). Já a Segunda Carta a Timóteo (2Timóteo) é escrita, com traços muito vívidos, como uma espécie de última comunicação escrita entre o apóstolo e seu auxiliar, onde o mesmo recebe o testamento de seu mestre e também seu mandato, por meio da imposição de suas mãos (cf. 2Timóteo 1,6). Apesar de não dizer explicitamente que, na situação imaginada, Timóteo estaria em Éfeso ou qualquer outro lugar da Ásia, existe uma série de menções diretas e indiretas à região no documento. Brown nota que, na carta, o apóstolo pede que Timóteo leve a ele um manto e alguns livros e pergaminhos que havia deixado em Trôade (2Timóteo 4,13), o que poderia ser evidência de que o cooperador seria imaginado como estando nessa cidade costeira da Ásia (BROWN, 1997: 673). O lamento do apóstolo logo na parte inicial da carta é significativo neste sentido:

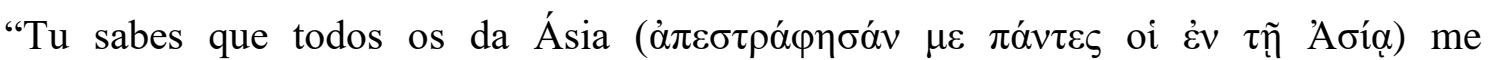
abandonaram, dentre eles Figelo e Hermógenes" $(1,15)$. Do mesmo modo, logo após, "Paulo" relembra os serviços de um tal Onesíforo e roga que Deus tenha misericórdia de sua família (aparentemente, o autor coloca-o já como morto à época da escrita da carta), uma vez que ele o teria auxiliado quando se encontrava preso em Roma e teria sido de muito valor quando de sua atividade em Éfeso (1,16-18). Por fim, ao final da carta, saudações especiais são enviadas tanto à mesma família de Onesíforo quanto ao casal Prisca e Áquila, tradicionalmente vinculados a Éfeso $(4,19)$. Assim, o vínculo entre 2Timóteo e a Ásia (talvez, mais particularmente, a Éfeso) apresenta-se como, no mínimo, uma forte possibilidade, embora não possamos ir além do âmbito da hipótese

\footnotetext{
${ }^{64}$ Diz Brown: "Overall they are very homogeneous in style and atmosphere. A logical deduction is that either the same person wrote them or, if $\mathrm{X}$ wrote one and $\mathrm{Y}$ wrote the others, $\mathrm{Y}$ has taken great pains to mimic X. Nevertheless, important scholars have objected that treating the three as a group has blinded interpreters to their individual differences" (BROWN, 1997: 638-9).
} 
(TREBILCO, 2004: 206) ${ }^{65}$. Já a Carta a Tito é explicitamente conectada a Creta, ao menos na ambientação do texto feita pelo autor, com Paulo deixando esse seu outro importante auxiliar na ilha para organizar as comunidades cristãs aí fundadas recentemente (cf. Tito $1,5)$.

No entanto, qual a real relevância das duas cartas a Timóteo para uma análise do cristianismo na Ásia? Afinal, sendo elas criadas muito provavelmente após a morte de Paulo, talvez até mesmo três décadas depois, não podemos ter a segurança de que o autor está se dirigindo por via epistolar a um personagem importante na região, podendo ser tudo uma mera ficção. Certamente essa é uma possibilidade que não podemos descartar inteiramente. Considerando a relevância que o cristianismo asiático (e, em especial, a igreja de Éfeso) assumiu principalmente a partir do último terço do século I d.C., adentrando pelo primeiro quarto do século II d.C., frente às igrejas de outras áreas do Mediterrâneo, e levando em conta também a importância de Éfeso em particular no ministério de Paulo, não poderia nos surpreender se o autor das ditas "Cartas Pastorais" optasse por utilizar essa parte do império (que, como visto no capítulo 1, expandia-se economicamente e em influência política justamente no período da escrita das cartas referidas) como palco para o que coloca sob a autoria e autoridade do apóstolo ${ }^{66}$.

No entanto, Paul Trebilco argumentou convincentemente por outra leitura das Cartas Pastorais, na qual cada uma das três deve ser inserida em uma situação específica (apesar, de forma paradoxal, ainda afirmar que prefere encarar as três cartas em conjunto), ainda que compartilhando de um mesmo autor desconhecido (TREBILCO, 2004: 206-9). O principal argumento que fundamenta a tese de Trebilco está nas diferenças entre os documentos. Em primeiro lugar, como visto, Éfeso não é o único palco escolhido, com a carta a Tito sendo inserida no contexto cretense, inclusive com duras e enigmáticas críticas aos habitantes da ilha ("Um dos seus próprios profetas disse: 'Os cretenses são sempre mentirosos, animais ferozes, comilões vadios"”, Tito 1,12) que mostram a preocupação do autor com a organização e manutenção da ordem de comunidades cristãs em uma região que ele considera especialmente problemática. Em segundo lugar, nota-se a diferença de objetivos, ainda que a temática seja semelhante: embora todas as três cartas se ocupem, mais ou menos dependendo de cada caso, do problema dos desvirtuamentos

\footnotetext{
${ }^{65}$ Trebilco nota que 2Timóteo afirma ser uma carta de Paulo escrita em sua prisão em Roma, o que poderia apontar para um autor residente na capital imperial e bem informado da situação da comunidade cristã em Éfeso, algo em nada impossível (TREBILCO, 2004: 205).

${ }^{66}$ Kümmel afirma que uma composição das Pastorais em qualquer lugar da Ásia Menor é "improvável”, mas sem dar argumentos para sua tese. Cf. KÜMMEL, 2004: 507.
} 


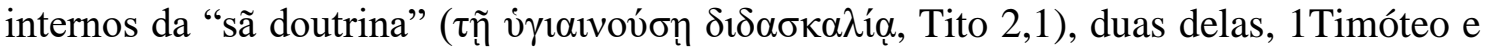
Tito, se utilizam de um ordenamento dos quadros administrativos da igreja de modo a garantir a manutenção da ordem e da unidade, enquanto 2Timóteo lança mão, como visto, de um discurso testamentário da parte do apóstolo Paulo, no qual ele se coloca do lado de uns contra outros. Em terceiro lugar, mesmo entre aquelas cartas ocupadas com o ordenamento comunal existem diferenças consideráveis nos modelos apresentados:

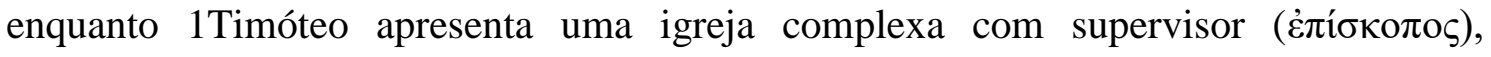

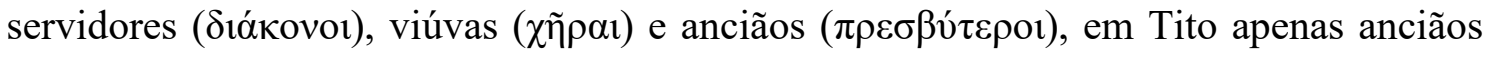
(equiparados aos supervisores) são citados, do mesmo modo que na primeira carta a preocupação do autor encontra-se em estabelecer regras para o acesso de membros da comunidade a cargos preexistentes ao documento, enquanto que, no segundo caso, Tito é instado a constituir quadros nas igrejas das cidades de Creta. Isso se faz compreensível se temos vista que a primeira carta se encontra vinculada, de alguma forma, a Éfeso, cuja comunidade cristã já poderia estar consideravelmente desenvolvida em fins do século I desde sua fundação em meados do mesmo século, enquanto que, de Creta, nada sabemos tanto pelas epístolas paulinas consideradas autênticas quanto pelos Atos dos Apóstolos, podendo ser uma região cristianizada não muito tempo antes da escrita das ditas Cartas Pastorais. É possível, portanto, lermos ao menos a 1Timóteo como ligada de alguma forma à igreja de Éfeso e à Ásia ${ }^{67}$, podendo mesmo conter em seu texto representações de processos sociais e conflitos internos à comunidade cristã na metrópole por volta das últimas duas décadas do século I d.C. É uma leitura, contudo, que deve ser feita com cuidado, recordando que estamos trabalhando com um texto que é, muito provavelmente, do gênero de ficção epistolar.

\subsection{3: Os Atos dos Apóstolos}

Ainda conectada de alguma forma ao apóstolo Paulo temos outra fonte, que, ao contrário das anteriores, não se enquadra no gênero epistolar. O livro tradicionalmente chamado "Atos dos Apóstolos" constitui um documento singular nos estudos sobre o primeiro século do cristianismo: de fato, para muitos estudiosos atualmente, ele é a primeira obra antiga que se pretende de história a focar-se na formação e primeira

\footnotetext{
${ }^{67}$ Wild, de sua parte, refere que o enfoque das Pastorais em comunidades cristãs existentes na região do Egeu e, especialmente, na Ásia Menor, "levou a maioria dos biblistas a supor que as Pastorais tenham se originado em algum lugar desta região, talvez em Éfeso" (WILD, 2011: 637).
} 
expansão da fé cristã pelo Mediterrâneo (FITZMYER, 2010: 48; MARGUERAT, 2003: 13-35) ${ }^{68}$. Na verdade, os Atos dos Apóstolos são a segunda parte de uma obra em dois volumes, incluindo aí também o chamado Evangelho de Lucas, dedicada a um personagem histórico desconhecido de nome Teófilo ${ }^{69}$. Na primeira parte do todo, o autor anônimo $^{70}$ faz uma espécie de biografia de Jesus de Nazaré, até o momento de sua ressurreição e ascensão aos céus; na segunda, partindo da ascensão do Cristo, é apresentado um relato da fundação sobrenatural da Igreja na cidade de Jerusalém durante a festa de Pentecostes e de sua expansão pelas cidades mediterrânicas sob o jugo romano. O objetivo do autor com seu escrito, como ele mesmo o diz ao início do que conhecemos como "Evangelho de Lucas" (Lucas 1,4), é demonstrar ao seu leitor cristão (personificado em Teófilo) a solidez histórica e doutrinal do ensinamento que recebeu e que ainda está recebendo no momento em que lê.

A utilidade dos Atos dos Apóstolos para a análise baseia-se nos capítulos que dedica à atividade do apóstolo Paulo em Éfeso, com uma pequena parada em Mileto ao fim do arco, sendo contemplada por dois capítulos inteiros (Atos 19-20). Éfeso é a cidade sobre da qual o autor mais se dedica a relatar a evangelização, depois de Jerusalém, o centro difusor original do que ele chama de "o Caminho" (ódós; Atos 9,2; 22,4). No entanto, apesar de o texto pertencer (ou ao menos buscar pertencer) ao gênero histórico clássico, existe uma série de problemas metodológicos na abordagem do documento. Uma comparação rápida entre os Atos dos Apóstolos e as cartas paulinas ditas "autênticas" apresenta certas semelhanças entre ambos os materiais no que tange a vida e o ministério de Paulo, mas uma série de discrepâncias também são trazidas à luz ${ }^{71}$. Isso

\footnotetext{
${ }^{68}$ Embora não seja ainda, como aponta Momigliano, uma obra do gênero da história eclesiástica, nos moldes que haveriam de ser formulados por Eusébio, ainda que ele certamente encontrasse nos Atos uma de suas principais inspirações (MOMIGLIANO, 2004: 197).

69 Considerando a pessoa a quem é dedicada a obra, Marguerat conferiu à obra como um todo (por vezes referida academicamente como "Lucas-Atos") o título sugestivo de Ad Theophilum (MARGUERAT, 2003: $55)$.

70 As primeiras referências ao colaborador de Paulo chamado Lucas (Filêmon 24; Colossenses 4,14; 2Timóteo 4,11) como autor da obra dupla, a qual nos referimos aqui, se dão já no século II, no prólogo antimarcionita ao evangelho, no chamado Cânone Muratoriano e em Irineu de Lyon (Contra as heresias $3.1 .1 ; 3.14 .1)$. O debate a respeito desse ponto, contudo, é muito vasto e nos referiremos aqui apenas a algumas posições básicas que representam bem o conjunto das diferentes visões. Fitzmyer reafirma a autoria tradicional por parte de Lucas, embora aceitando que o mesmo poderia não ser um companheiro inseparável de Paulo (FITZMYER, 2010: 50). Koester não aceita uma autoria por parte de um discípulo de Paulo, mas considera que o autor poderia se chamar realmente Lucas, gerando a confusão tradicional (KOESTER, 2012: 331). Marguerat também nota diferenças teológicas básicas entre o mesmo e o apóstolo, o que argumentaria contra a versão legada pela tradição (MARGUERAT, 2003: 19). Já Dillon rejeita tanto a autoria por parte de um discípulo de Paulo ou mesmo de um cristão chamado Lucas (DILLON, 2011: 310-1).

${ }^{71}$ Um excelente quadro comparativo entre as informações biográficas de Paulo fornecidas por suas cartas e pelos Atos dos Apóstolos encontra-se em CARREZ, 2008: 23-8. Koester chega a afirmar que "é muito
} 
sugere que, embora os Atos constituam uma fonte fundamental para uma visão geral acerca do cristianismo mais antigo e mesmo do Mediterrâneo romano de meados do século I d.C. (inclusive com a referência a personalidades historicamente conhecidas, como Galião, governador da Acaia; cf. Atos 18,12), não pode ser alvo de confiança automática por parte do historiador. De fato, o autor, como um bom literato e hábil utilizador da língua e literatura gregas, tece uma narrativa que não é constituída meramente por episódios esparsos e recordações tradicionais, mas por um texto permeado por um único objetivo que o guia do início ao fim, o que faz certamente com que ele ajuste o material tradicional recebido de modo a adequar-se ao que ele espera que sua obra seja e represente ao final (cf. MARGUERAT, 2003: 37-90). Nas palavras de Vasconcellos e Funari: “A História era um gênero narrativo que visava agradar o leitor, mesmo quando afirmava estar preocupada com a verdade dos fatos" (VASCONCELLOS e FUNARI, 2013: 12).

Deste modo, podemos concluir que a utilização da narrativa dos Atos dos Apóstolos é primordial para o capítulo 2 da dissertação, embora não deva de forma alguma ser uma abordagem sem a preocupação crítica básica, com a verificação (quando possível) da fiabilidade das informações contidas no texto.

\subsection{4: O Apocalipse de João}

Devemos destacar outra fonte sem a qual teríamos uma visão muito mais deficiente do que seja este cristianismo antigo na Ásia, especialmente em fins do século I d.C.: o Apocalipse escrito por determinado João (que muito provavelmente não era o mesmo João filho de Zebedeu que fazia parte do grupo seleto dos $\operatorname{Doze}^{72}$ ) na ilha de Patmos, na costa egeia da Ásia Menor. O interesse que essa fonte tem para a análise é a conexão direta entre João e as comunidades cristãs presentes na província da Ásia Proconsular, visível de forma explícita por meio das cartas dirigidas pelo autor a sete

difícil encontrar no Livro dos Atos informações históricas úteis" (KOESTER, 2012: 339), o que é certamente um exagero, advindo de sua concepção de que os Atos pertenceriam ao gênero literário da epopeia.

${ }^{72}$ Praticamente nenhum autor moderno defende a visão corrente nas diferentes tradições cristãs de que o autor do Apocalipse seria o apóstolo João, filho de Zebedeu. A teoria mais comum atualmente é a de que seu autor seria um profeta cristão antigo (BROWN, 1997: 774; YARBRO COLLINS, 2011: 838; KÜMMEL, 2004: 621), provavelmente judeu oriundo da Palestina, dada a existência de semitismos em seu grego (TREBILCO, 2004: 293). O trecho que sugere mais fortemente que o autor seria pertencente a um grupo de profetas é Apocalipse 22,9, o qual registra as palavras de um anjo após João tentar prostrar-se diante dele: "Sou servo como tu e como teus irmãos, os profetas [ $\tau \tilde{\omega} \nu \dot{\alpha} \delta \varepsilon \lambda \varphi \tilde{\omega} v \sigma o v \tau \tilde{\omega} \nu \pi \rho \circ \varphi \eta \tau \tilde{\omega} v]$, e como aqueles que observam as palavras deste livro". 
igrejas da região colocadas no início da narrativa e nas quais ele escreve em nome de Jesus Cristo na primeira pessoa do singular. Por meio de tais cartas, ficamos sabendo de comunidades presentes em centros urbanos que, sem o Apocalipse, nos seriam inteiramente desconhecidas para o período das últimas décadas do primeiro século depois de Cristo, como Esmirna, Pérgamo, Tiatira, Sardes e Filadélfia.

O Apocalipse de João pertence, como o seu próprio nome deixa explícito, ao gênero apocalíptico, muito em voga no judaísmo tanto do século I d.C. quanto naqueles anteriores mesmo à conquista romana do Mediterrâneo oriental. Na verdade, a denominação do gênero provém justamente do Apocalipse de João, um dos textos-base de toda a cristandade (COLLINS, 2010: 382). No entanto, paradoxalmente, pertence ele a um subgênero bem particular e raro. Em geral, os escritos apocalípticos judaicos versavam sobretudo acerca de aspectos do mundo celestial, sobretudo os que vieram a ser considerados apócrifos (como o "Livro de Enoch", por exemplo), visando sobretudo aprofundar as informações concedidas pela "Lei e os Profetas". O Apocalipse de João, por outro lado, assim como os chamados Oráculos Sibilinos, não se preocupa tanto em explanar acerca do Céu e das divisões dos anjos quanto a oferecer um retrato, recheado de simbolismos tradicionais judaicos e citações das Escrituras, do juízo iminente de Deus sobre um mundo corrompido pela idolatria e pelo pecado (cf. KOESTER, 2012: 266276). Trata-se, portanto, de um juízo sobre a sociedade habitada e, ao mesmo tempo, rejeitada pelo autor, o que faz do livro uma fonte particularmente formidável, especialmente quando trata direta e explicitamente dos problemas específicos de cada uma das sete igrejas às quais é escrita. Se, portanto, pelo Apocalipse recebemos uma representação vívida (ainda que, naturalmente, parcial) de conflitos internos às comunidades e sua relação com a sociedade urbana que as abrange, por outro lado traznos o desafio de ler por trás das figuras simbólicas apresentadas pelo autor para rechear seu escrito de misticismo profético.

\subsection{5: Fontes correntemente utilizadas pelos estudiosos, mas que apresentam problemas de ambientação}

As fontes cristãs do século I d.C. elencadas até aqui são, como já dito, aquelas com pelo menos alguma vinculação direta com as cidades da província da Ásia Proconsular, mesmo que seja a nível de citação das mesmas no texto, sem uma necessária autoria por parte de membros das comunidades aí presentes. No entanto, outras fontes já 
foram usadas em estudos sobre o cristianismo asiático sem ter, necessariamente, alguma conexão explícita com a região, permanecendo a mesma apenas em nível hipotético, o que traz severas consequências para a análise. Apresentamos, aqui, alguns casos, sugerindo, também, um método para sua utilização sem necessariamente comprometer a análise.

\subsubsection{1: Evangelhos}

Certamente um tipo de fonte altamente utilizada para reconstruir comunidades cristãs do primeiro século depois de Cristo é o evangelho. De fato, desenvolveu-se sobretudo no século XX a teoria metodológica segundo a qual os evangelhos que hoje conhecemos como "canônicos" (isto é, Marcos, Mateus, Lucas e João) seriam composições de natureza eminentemente teológica, feitas com o objetivo maior de atender a necessidades de comunidades cristãs específicas. Tais necessidades seriam discerníveis por meio de análises minuciosas dos textos, sobretudo com a comparação entre os materiais evangélicos, de modo a realçar as diferenças entre as narrativas e questionar acerca dos interesses por trás das mesmas. Para termos acesso aos objetivos específicos de cada texto e podermos, dessa maneira, compor uma espécie de narrativa da história de comunidades específicas, seriam utilizadas tanto uma crítica das formas (ou do gênero literário) quanto uma crítica redacional. A crítica das formas lida com as problemáticas em torno do gênero de um texto específico, que tem papel de maior importância para a forma como o seu conteúdo é apresentado. Considerando as especificidades do gênero de um texto específico (ou dos gêneros diversos presentes nele), é possível emitir um juízo melhor fundamentado acerca do que ele diz. Já a crítica redacional considera que a inclusão de determinados componentes individuais em um mesmo texto modifica consideravelmente o seu significado, ou seja, a informação que ele pretende transmitir. Raymond E. Brown sintetiza da seguinte forma a utilização das duas metodologias para o estudo dos evangelhos: "A crítica das formas se concentrou nas unidades preexistentes compiladas pelos evangelistas; a crítica redacional, ou pelo menos a sua ala melhor chamada de crítica do autor, reconheceu que os autores criativamente davam forma ao material que haviam recebido" (BROWN, 1997: 23). Os evangelhos, conforme a utilização corrente das duas metodologias, seriam textos compostos pelas comunidades em contextos particulares, de modo que poderíamos falar em uma comunidade de Mateus, outra de Marcos e uma terceira de Lucas, por exemplo. A partir 
de tal teoria, concebia-se a possibilidade mesmo de se construir toda a história de uma comunidade utilizando como fonte única o evangelho por ela produzido. É o que fez Raymond E. Brown no clássico A comunidade do discípulo amado, fundamentado sobretudo em uma análise minuciosa do Evangelho de João.

Por muitas décadas, tal pressuposto teórico-metodológico permaneceu praticamente como um consenso acadêmico. No entanto, sobretudo a partir da última década do século XX, e apesar de a relevância das duas metodologias em si nunca ter sido questionada seriamente, severas críticas começaram a ser reunidas contra o dito consenso por um grupo de acadêmicos, dos quais se destacava Richard Bauckham ${ }^{73}$. Dentre elas, encontrava-se o questionamento da própria natureza comunal da escrita dos evangelhos advogada pela velha escola, com os evangelistas sendo pouco mais do que redatores de uma série de tradições que fundamentavam a identidade das comunidades específicas. A nova escola, de sua parte, retornava a uma ênfase do caráter autoral dos específicos, realçando a liberdade dos respectivos escritores na escolha das tradições que viriam a ser redigidas ou mesmo na composição de narrativas de sua própria parte. Um segundo questionamento levantado pelos críticos era aquele relativo à vinculação necessária entre um determinado evangelho e uma comunidade, que seria por ele representada (BAUCKHAM, 1998: 11). Ao invés, foi notado, tanto por Bauckham quanto por Michael B. Thompson, o alto grau de circulação humana entre as comunidades cristãs já no século I d.C., o que enfraqueceria o pressuposto de um autor necessariamente fixo a uma comunidade específica (BAUCKHAM, 1998: 32-8; THOMPSON, 1998). Foi um severo golpe contra uma suposta destinação restrita dos evangelhos, e daí vem a terceira crítica: se não há como comprovar, nem pelos textos em si e nem por fontes externas, que os materiais evangélicos deveriam ser lidos por comunidades específicas, torna-se impraticável seu uso para uma análise de tais comunidades. Um trabalho, como o já citado A comunidade do discípulo amado, perderia boa parte de seu sentido.

Isso não significa, contudo, que os evangelhos percam sua importância para uma análise de igrejas cristãs específicas claramente traçáveis por meio da documentação, como no caso daquelas existentes na Ásia Proconsular. Pelo contrário: a ausência de uma restrição geográfica clara para tais evangelhos, uma vez que tal não é colocada pelo texto em si (nenhum dos autores explicita o local onde está escrevendo) permite-nos utilizar o material de modo a elucidar problemas que possam ser sugeridos pelas fontes sobre as

\footnotetext{
${ }^{73}$ Para o que será dito a seguir, vale a leitura de todo o volume organizado por Bauckham: BAUCKHAM,
} 1998. 
quais nos focamos (BAUCKHAM, 1998: 45-6). Pois, se não é possível esclarecer onde foram escritos (ou mesmo se foram escritos em algum lugar específico), podemos atestar sua recepção, o que sugere por si só que esses materiais teriam algo a dizer para aquele público específico. No caso da Ásia, por exemplo, podemos atestar explicitamente, ainda que parcialmente, a recepção de Mateus e Marcos desde, pelo menos, Pápias de Hierápolis, nas primeiras décadas do século II d.C. (cf. Eusébio de Cesareia, História Eclesiástica III.39,14-17), conforme escreveu em sua obra (conhecida apenas por fragmentos citados por Eusébio de Cesareia e Irineu de Lyon) "Exegeses das sentenças do Senhor"74. Do mesmo modo, existem pontos de contato (ainda que não seja propriamente uma relação de dependência literária) entre o Apocalipse de João e o chamado Evangelho de João, tradicionalmente consideradas obras do mesmo autor, o apóstolo João, mas hoje universalmente tidos academicamente como originários de personalidades claramente distintas ${ }^{75}$.

\footnotetext{
${ }^{74}$ Em um outro trabalho seu, intitulado Jesus e as testemunhas oculares: Os Evangelhos como testemunhos de testemunhas oculares, Bauckham defendeu a tese de que Pápias também teria feito referência, em sua obra, ao Evangelho de João, ainda que Eusébio não o cite nesse ponto. A razão do silêncio de Eusébio seria dupla: por um lado, Pápias teria afirmado ser o obscuro João, o Ancião, o autor do Evangelho, e não o apóstolo filho de Zebedeu, conforme defendia o historiador; por outro, o líder cristão de Hierápolis daria preferência, em sua obra, ao Evangelho de João em detrimento daqueles referidos como de Mateus e de Marcos, o que iria de encontro à tese amenizadora de Eusébio, segundo a qual o quarto evangelho canônico teria sido escrito para complementar as informações fornecidas pelos outros três, fornecendo primordialmente informações acerca do início do ministério de Jesus (cf. História Eclesiástica III.24,7-13). O fundamento para a tese de Bauckham seria uma suposta dependência literária de Irineu de Lyon e, principalmente, do chamado Cânon Muratoriano em relação a Pápias, com o último documento dando a entender (na leitura de Bauckham) que o João autor do evangelho não seria o apóstolo de mesmo nome. Tal leitura do Cânon, contudo, está longe de ser certa, por mais atraente que seja a proposta. Tudo isso faz toda a teoria de Bauckham ser deveras frágil, o que nos leva a optar pelo caminho mais seguro de considerar que não há evidências concretas que indiquem que Pápias teria feito referência ao Evangelho de João em sua obra, por mais que a listagem parcial que faz dos apóstolos (cf. História Eclesiástica III.39,4) guarde semelhanças com a do dito evangelho (o que poderia ser explicado, por exemplo, pelo compartilhamento de uma tradição oral comum). Cf. BAUCKHAM, 2011: 525-556. Vale notar que Trebilco, como bom seguidor de Bauckham, aceita sua tese (TREBILCO, 2004: 246-258). Notemos, por fim, que Irineu cita um trecho de Pápias que faz referência a uma tradição supostamente advinda de João, o Ancião, que poucas semelhanças guarda com o conteúdo de qualquer um dos escritos joaninos (Contra as heresias V.33,1-5), possuindo uma certa tendência milenarista completamente estranha à escatologia realizada presente no Evangelho de João (cf. João 3,17-19).

${ }^{75}$ As principais diferenças entre Apocalipse e o material joanino encontra-se no campo do estilo, forma de expressão do grego e teologia, sobretudo no que tange a escatologia. Propostas não convincentes (dado o peso das evidências) foram apresentadas para defender uma autoria comum, como o uso de diferentes escribas ou secretários (argumento forçoso e comum entre os defensores incondicionais das autorias tradicionais dos escritos neotestamentários) ou os efeitos da passagem do tempo para o autor entre a escrita de uma obra e de outra. No entanto, os pontos de contato existem, principalmente no uso do título "Cordeiro" para designar Cristo (embora com palavras gregas diferentes sendo usadas; João 1,29.36; Apocalipse 5,6; 6,16; etc.) e expressões como "água viva" (João 4,10-11; 7,38) e "água da vida" (Apocalipse 7,$17 ; 21,6 ; 22,1.17$ ). Uma explicação possível para tais semelhanças pode ser a dependência de ambos os escritos de uma tradição anterior ou mesmo por uma adaptação independente da tradição judaica. Ver YARBRO COLLINS, 2011: 838. Devemos lembrar, também, que estudiosos contemporâneos têm notado vínculos entre os autores das duas obras com a Palestina (para o João de Apocalipse, ver TREBILCO, 2004: 293; para o autor do evangelho, cf. BROWN, 1997: 368-371).
} 


\subsubsection{2: Material joanino}

Tendo citado A comunidade do discípulo amado, de Raymond E. Brown, cabenos fazer uma observação acerca do material por ele analisado. É o que chamamos aqui de "material joanino", ou seja, a coletânea de escritos presentes no cânon do Novo Testamento e que recebem os nomes, respectivamente, de Evangelho de João e Primeira, Segunda e Terceira Cartas de João, normalmente considerados em conjunto pelas grandes similaridades e considerável dependência entre si, seja por serem todos obra de um mesmo autor (TREBILCO, 2004: 264-7) ou de pessoas pertencentes a um mesmo grupo ou comunidade (PERKINS, 2011: 818-820). A necessidade de discutirmos esse material baseia-se no fato de sua composição ser com frequência vinculada à província da Ásia, mais especificamente à cidade de Éfeso (cf. BAUCKHAM, 2011: 525-556; BROWN, 1997: 334).

Desde o século II d.C. existe uma tradição, atestada tanto por Irineu de Lyon (Contra as heresias III.1,1; 3,4; 11,1) quanto por Polícrates de Éfeso, em carta preservada por Eusébio de Cesareia (História Eclesiástica V.24,2-3), de que teria residido na metrópole da Ásia um certo João, “discípulo do Senhor”. Esse João é identificado por um escrito anônimo também do século II d.C., os Atos de João, como sendo o filho de Zebedeu (Atos de João 88), integrante do grupo dos doze discípulos mais próximos de Jesus de Nazaré (Marcos 3,17; Mateus 10,2; Lucas 6,14; Atos 1,13) e considerado, ao menos por Paulo, uma das três colunas da Igreja, junto com Pedro, outro membro dos doze, e Tiago, o "irmão do Senhor" (Gálatas 2,9). Segundo Irineu (ver citação na página anterior), João teria sido responsável pela composição do evangelho que hoje leva o seu nome, enquanto residia em Éfeso, no fim de sua vida; essa versão sobre a origem do Evangelho de João tornou-se a oficial entre as grandes tradições cristãs. Sobretudo durante o século XX, porém, desenvolveu-se entre teólogos e exegetas questionamentos quanto à tese tradicional, tanto de que João, filho de Zebedeu, teria sido o autor do evangelho ${ }^{76}$, quanto que teria esse escrito tido origem em Éfeso. O próprio Raymond E. Brown, primeiramente tendente à tese tradicional da autoria, veio depois a mudar de ideia e defender que o autor não seria membro do grupo dos Doze (cf. BROWN, 1984: 84), o que teria consequências em sua visão acerca das relações entre a "comunidade joanina" e os grupos cristãos desenvolvidos a partir da pregação dos doze apóstolos (BROWN,

\footnotetext{
${ }^{76}$ Uma boa narrativa sobre o debate acadêmico em torno da autoria do Evangelho de João até a segunda metade do século XX encontra-se em KÜMMEL, 2004: 248-252.
} 
2011: 84-92). Por outro lado, outras localidades, como Egito e Síria, foram sugeridos para a composição do evangelho, a última região sendo preferida por Koester e Kümmel por conta dos aparentes contatos literários e conceituais entre João e escritos de autoria síria como as "Odes de Salomão" e as próprias cartas de Inácio de Antioquia77 (KOESTER, 2012: 194; KÜMMEL, 2004: 315). Um retorno parcial à tese tradicional, pelo menos no que tange o local de composição da obra, foi advogado por Paul Trebilco (TREBILCO, 2004: 241-263), fundamentando sua teoria nos já citados testemunhos de Irineu e Polícrates e adicionando aquele fornecido pelo Cânon Muratoriano ${ }^{78}$, e defendendo que o João que seria o autor do evangelho não era o filho de Zebedeu e membro dos Doze, mas sim um "ancião" com o mesmo nome, ao qual Pápias de Hierápolis ${ }^{79}$ faz referência como sendo um dos responsáveis por legar às gerações pósteras de cristãos as palavras dos apóstolos que tinha conhecido (embora o mesmo Pápias nunca vincule João o Ancião com a cidade de Éfeso).

\footnotetext{
${ }^{77} \mathrm{Na}$ verdade, em nenhum momento Inácio cita literalmente qualquer material joanino. O único documento do cânon neotestamentário explicitamente por ele utilizado mais de uma vez é 1Coríntios (SCHOEDEL, 1985: 10). Existem, contudo, certamente pontos de considerável contato entre alguns temas presentes em Inácio e no material joanino (Ibidem: 11). Em In.Efésios 14,2, por exemplo, o antioqueno diz: "Ninguém

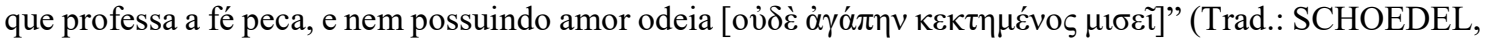
1985: 75). 1João também se volta para a mesma incompatibilidade entre fé e pecado, assim como entre amor e ódio (1João 3,4-10; 5,18). No entanto, o mesmo Schoedel considera que a possibilidade de haver aqui uma relação de dependência literária é pequena, sendo preferível se pensar em um compartilhamento de uma mesma tradição por parte das duas fontes (SCHOEDEL, 1985: 11). Brent, de sua parte, enxergou na forma como Inácio descreve uma reunião cristã ideal (o supervisor no centro da "guirlanda" formada pelos anciãos ao seu redor) uma referência à cena da aparição de Jesus aos discípulos na sala de cima de uma casa em Jerusalém, com o primeiro soprando o Espírito Santo sobre os últimos (BRENT, 2009: 86). Tal cena encontra-se presente, conforme o próprio Brent destaca, em João 20,19-23. No entanto, Brent claramente força a mão aqui, uma vez que nenhuma conexão textual clara pode ser traçada entre os dois documentos, inclusive com o ato de provável caráter ritual mais importante da cena joanina, a saber, a imposição do Espírito Santo pelo sopro (DESTRO e PESCE, 2010: 51), não encontrando qualquer espaço nas cartas inacianas, nem mesmo no trecho de In.Magnésios 13,1-2 que ele utiliza em sua argumentação.

${ }^{78}$ O "Cânon Muratoriano" é uma lista em latim de livros que deveriam ser aceitos por uma determinada comunidade cristã não especificada, mas que provavelmente deveria ser a residente na capital, Roma, tendo-se em conta que o documento faz referência a Pio, líder da igreja local, como sendo irmão de Hermas, autor do escrito apocalíptico chamado "O Pastor". O mais provável é que tenha sido escrito por volta do século II d.C. (TREBILCO, 2004: 249), embora alguns, como Koester, prefiram datá-lo como sendo de uma época mais tardia, possivelmente no século IV d.C. (KOESTER, 2012: 12-3; ver também B. MARTIN, 2012: 24). O trecho debatido por Trebilco, seguindo Bauckham, é o que segue: "O quarto dos evangelhos é aquele de João, [um] dos discípulos. Quando seus codiscípulos e bispos [condiscipulis et episcopis] lhe instaram, ele disse: 'Jejuai comigo hoje por três dias e, o que for revelado a cada um, contemos um ao outro'. Naquela mesma noite foi revelado a André, um dos apóstolos, que, com todos eles revendo, João deveria descrever todas as coisas em seu próprio nome" (Cânon Muratoriano 10-14; Trad. e ed.: THERON, 1954: 106-113).

${ }^{79} \mathrm{O}$ trecho no qual Pápias faz referência a João, o ancião, encontra-se em Eusébio de Cesareia, História Eclesiástica III.39,1-4: "Mas, toda vez que alguém chegava que havia sido companheiro de um dos anciãos ( $\tau$ oĩ $\varsigma \rho \varepsilon \sigma \beta v \tau \varepsilon \dot{\varepsilon} \rho o 1 \varsigma$ ), eu cuidadosamente os inquiria acerca das palavras dos anciãos ( $\tau \tilde{\omega} v \pi \rho \varepsilon \sigma \beta v \tau \varepsilon \dot{\varepsilon} \rho \omega v)$, o que André e Pedro haviam dito, ou o que Filipe ou o que Tomé haviam dito, ou Tiago ou João ou Mateus ou qualquer outro dos discípulos do Senhor, e que que coisas Aristion e o ancião João (ó $\pi \rho \varepsilon \sigma \beta v ́ \tau \varepsilon \rho o \varsigma$ 'I
} 
A tese de Trebilco possui peso, mas não versa acerca do próprio Evangelho de João, uma vez que ele se coloca explicitamente em seguimento do grupo de estudiosos reunidos em torno de Richard Bauckham no que tange os pressupostos teóricometodológicos de análise dos evangelhos (TREBILCO, 2004: 237-241). Contudo, para sua história dos primeiros cristãos de Éfeso, Trebilco faz uso das chamadas cartas de João, que ele defende terem sido escritas pelo mesmo autor do evangelho, para representar uma comunidade cristã específica existente na metrópole asiática e que seria independente daquela originada da pregação de Paulo, espelhada, segundo ele, pela 1Timóteo. No entanto, tal uso não ocorre sem complicações. De fato, o autor nunca refere o local de onde está escrevendo, como o faz Paulo em algumas de suas cartas (ver o que foi dito acerca das cartas de Paulo anteriormente, especialmente 1Coríntios). Ora, o mesmo princípio que Bauckham aplica para os evangelhos pode ser utilizado para cartas, especialmente quando um autor pode ter escrito ambos: não podemos saber se o seu autor é um membro fixo de uma comunidade cristã urbana específica ou se é o mentor maior de uma série de comunidades espalhadas por várias localidades ${ }^{80}$, estando ele em frequente movimento entre elas, o que, aliás, parece ser sugerido pela Terceira Carta de João:

Escrevi algumas palavras à Igreja. Mas Diótrefes, que ambiciona o

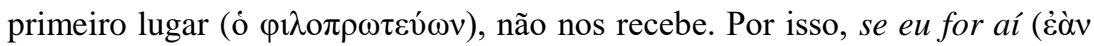
ह̌ $\lambda \theta \omega)$, repreenderei a sua conduta, pois ele propaga palavras más contra nós. (...) Teria muitas coisas a dizer, mas não quero fazê-lo com tinta e pena. Espero

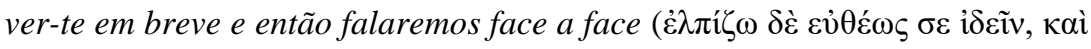
$\sigma \tau o ́ \mu \alpha \pi \rho \grave{\varsigma} \sigma \tau o ́ \mu \alpha \lambda \alpha \lambda \eta ́ \sigma o \mu \varepsilon v)$. (3João 9-10.13-14; grifos meus)

Além disso, em nenhum lugar da documentação encontra-se dito, explícita ou implicitamente, que tais comunidades devessem estar restritas a Éfeso ou à Ásia ou mesmo que aí estivessem presentes. Por outro lado, apesar de a tradição que vincula o Evangelho de João a Éfeso ser forte no segundo século depois de Cristo, ela possui fraquezas consideráveis. Seu maior proponente é Irineu de Lyon, que afirma tê-la

\footnotetext{
${ }^{80}$ Notemod, por exemplo, o trecho de 3João 5: "Caríssimo, procedes fielmente agindo assim com teus

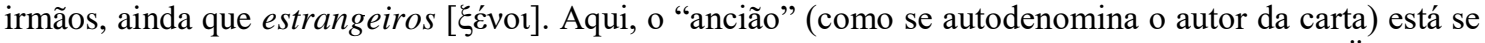
dirigindo a um certo Gaio, que, aparentemente, pertence à mesma corrente cristã que a sua (KÜMMEL, 2004: 587; MOFFAT, 1918: 477; PERKINS, 2011: 833), e é interessante como ele faz referência a missionários "estrangeiros". Bonnard se pergunta se aqui a expressão não se refere a membros da mesma comunidade joanina vindos de outras províncias (BONNARD, 1983: 132), o que sugeriria que tal corrente não estaria restrita a uma única região.
} 
recebido quando criança de Policarpo de Esmirna, que seria, de sua parte, discípulo do próprio João (Contra as heresias III.3,4; Carta a Florino, presente em História Eclesiástica V.20,4-8). No entanto, o próprio Policarpo nas duas cartas de sua autoria e em seu Martírio, narrado pela comunidade de Esmirna, nunca faz referência a tal fato de sua biografia, o que é, no mínimo, estranho, se considerarmos também que ele faz pouco uso do material joanino em sua carta maior dirigida aos filipenses ${ }^{81}$.

Deste modo, apesar de existirem evidências de considerável peso para uma vinculação entre o material joanino e a Ásia, seria no mínimo temerário tomá-lo como uma fonte fundamental (o que ele de fato seria nesse caso) para uma análise do cristianismo em Éfeso no primeiro século depois de Cristo, como o faz Trebilco. No máximo, o que podemos fazer é, assim como optamos no caso dos evangelhos, utilizá-lo como fontes que nos ajudam a elucidar certos aspectos do cristianismo asiático por meio de um método comparativo, sem, contudo, assumi-los como documentos próprios da Ásia ou de Éfeso em particular.

\subsection{6: "Apócrifos"}

Um último grupo de documentos aos quais precisamos fazer referência aqui são aqueles escritos chamados de "apócrifos" ${ }^{82}$, ou seja, aquelas obras que, reclamando, em geral, uma autoridade apostólica (embora haja exceções em ambos os casos, como com o Evangelho de Filipe, que, apesar de seu nome comum, não afirma em nenhum momento

\footnotetext{
${ }^{81} \mathrm{O}$ único trecho da carta de Policarpo que possui vínculo claro com o material joanino (no caso, com 1João) é o que segue: "Pois quem quer que não confesse que Jesus Cristo veio na carne é um anticristo; e quem quer que não confesse o testemunho da cruz é do diabo..." (Pol.Filipenses 7,1). Comparar com 1João $4,2-3 ; 3,8$.

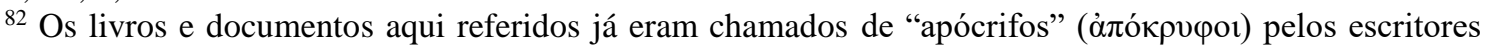
eclesiásticos anteriores ao Concílio de Niceia. Clemente de Alexandria, por exemplo, afirmava que os gnósticos apelavam a "livros apócrifos" (Stromata I.15,69). Do mesmo modo, Tertuliano acusa a obra "O Pastor" de Hermas de estar entre os livros "apócrifos e falsos" [apocrypha et falsa] (De Pudicitia 10,12). Embora já tenha sido sugerido que as igrejas cristãs teriam recebido sua noção de "livros apócrifos" da classificação feita entre comunidades judaicas de livros que, não sendo aptos a serem utilizados em culto, não guardariam tampouco restrições quanto ao uso privado, Hennecke, no entanto, rejeita tal leitura, tendo em vista inclusive as citações feitas acima (especialmente Tertuliano). Para ele, o significado da utilização do termo "apócrifo" para referir-se a tais documentos deve ser buscado no significado literal da palavra grega: “... mantido em oculto por causa de seu alto preço ou por causa da natureza questionável de seu conteúdo", assim como também "de origem oculta" (HENNECKE, 1963: 25). Nesse mesmo trecho, ele aponta para papiros de origem esotérica, gnóstica ou mágica que utilizam tal termo para se referirem a si próprios. Nota-se, portanto, um jogo de sentidos no uso da palavra para classificação. Apesar de existir uma tendência atual de utilização mais abrangente do termo, recolhendo em sua sombra um número maior de documentos do que era usual até, pelo menos, meados do século XX (SHOEMAKER, 2008: 532), aqui nos restringiremos, de qualquer forma, aos textos não aceitos no cânon neotestamentário, mas que contém alguma relação temática com o mesmo, produzidos sobretudo nos primeiros três séculos do cristianismo.
} 
ter sido escrito pelo apóstolo de mesmo nome), foram, contudo, excluídos dos cânones aceitos pelas igrejas orientais e ocidentais. Tratam-se, sobretudo, de "tradições narrativas sobre a vida e ensinamento de Jesus, sua família e seus apóstolos, assim como cartas, visões apocalípticas e outras jornadas ao outro mundo atribuídos a esses indivíduos que se encontram fora do cânon bíblico" (SHOEMAKER, 2008: 521). O motivo para sua proscrição residia normalmente em acusações de heresia, principalmente no caso daqueles escritos vinculados aos grupos gnósticos, que vieram a se difundir pelo Mediterrâneo sobretudo no século II d.C. Embora alguns poucos tivessem sido preservados em manuscritos enfurnados em mosteiros, os apócrifos foram foco de um boom de interesse acadêmico e popular sobretudo com a descoberta de uma coleção enorme de manuscritos, de caráter sobretudo gnóstico, em uma tumba em Nag Hammadi no Egito, em 1945.

Certamente, seria de sumo interesse para a análise a utilização de fontes que não estivessem inseridas no cânon comum do Novo Testamento, aceito por praticamente todas as denominações cristãs hodiernamente. Elaine Pagels, por exemplo, em seu clássico The Gnostic Gospels, dedica todo um capítulo às consequências latentes da crença, existente entre alguns dos principais grupos gnósticos, da existência de dois deuses (o inferior, demiurgo do universo, e o superior, Pai de Jesus Cristo) para a convivência comunitária cristã, com os defensores de tal teologia se abrindo para o questionamento da autoridade do bispo único, aparentemente procedente daquele deus inferior que, na Lei hebraica, se arrogava ser o único existente (PAGELS, 1979: 28-47). Teríamos, desta forma, no mínimo, um outro olhar sobre os processos sociais que são foco de nosso estudo. Pagels mostra que muitos documentos apresentam, ainda que por vezes não abertamente, visões críticas e de desprezo com relação às formas de autoridade e concentração de poder na maioria das comunidades cristãs, e que escritores do mainstream ascendente, como no caso de Irineu de Lyon, não deixaram de notar esse fato (Ibidem: 38-9).

Contudo, existem limitações à utilização de tais documentos, que devem ser notados com cuidado. Primeiramente, em geral temos com esse material os mesmos problemas com os quais nos defrontamos quando da leitura dos evangelhos canônicos, como a ausência de uma referência clara ou ainda que implícita ao local onde a obra é composta. Deste modo, não podemos inferir que as teses advogadas por um escrito gnóstico, por exemplo, sejam de fato representativas de formas de pensar existentes no cristianismo da Ásia. Em segundo lugar, a datação dos documentos é um severo 
obstáculo: a maioria esmagadora dos apócrifos recebem datações relativas pelo século II d.C. adentro, alcançando o século III e se estendendo pelo IV (LAYTON, 1995: 5-8), ou seja, em um recorte cronológico para além daquele que focaremos aqui (embora exista uma grande possibilidade de alguns desses documentos serem contemporâneos a Inácio de Antioquia). Um caso, no entanto, pode ser destacado quanto à datação: o Evangelho de Tomé, do qual temos o texto quase integral, é um dos evangelhos apócrifos que recebem mais destaque na mídia cultural, assim como é um dos principais focos de estudos, sobretudo pela semelhança que guarda com o que estudiosos do Novo Testamento imaginam que seria a fonte hipotética Q (ou "Evangelho dos Ditos Sinóticos”, reconstruído a partir de comparações entre Mateus e Lucas; KOESTER, 2012: 4). O Evangelho de Tomé é considerado, ao menos por alguns acadêmicos, como oriundo do século I d.C., sendo, portanto, contemporâneo aos evangelhos tradicionalmente aceitos pelas confissões cristãs. Essa não é, contudo, uma visão indisputada, pois muitos outros estudiosos colocariam sua composição em datas bem mais tardias, inclusive em meados do século II d.C. (LAYTON, 1995: 377). Não deixa, porém, de constituir uma fonte impressionante, servindo indiretamente de retrato para um grupo possivelmente muito antigo que servia de alternativa para as comunidades que viriam a se desenvolver em ortodoxia.

Devemos, deste modo, tomar tanto o cuidado de não atentar demasiadamente para tais escritos, como de não ignorá-los. Principalmente no caso do Evangelho de Tomé, cabe a sua utilização tanto para comparar com os textos que utilizaremos, como também como um possível retrato parcial do que poderiam ser alguns adversários enfrentados por nossas fontes, principalmente no caso de Inácio de Antioquia.

\section{2: Caminhos de difusão}

A chegada do cristianismo à Ásia não era uma obviedade. Na verdade, nenhuma expansão do cristianismo era uma obviedade. Se os apóstolos tivessem rejeitado a inciativa de alguns grupos (dentre eles o de Paulo) de aceitar membros para o novo "Israel de Deus" sem a necessidade de circuncisão, não é possível dizermos se a nova fé teria chegado tão longe. No primeiro século depois de Cristo, o alcance de grandes centros urbanos não parecia ser um objetivo necessário dos missionários cristãos: de fato, os evangelhos nos apresentam um movimento em torno de Jesus que evita centros urbanos 
famosos da Galileia, como Séforis e Tiberíades ${ }^{83}$. Nunca devemos nos esquecer que Paulo não era necessariamente a regra; a escassez de documentação é que nos impede de fazer uma narrativa mais abrangente sobre a difusão da fé cristã antiga, e isso vale para todos os três primeiros séculos depois de Cristo. "Lamentavelmente", nas palavras de Thomas M. Finn, "as fontes históricas confinam sua atenção primordialmente ao mundo grecoromano" (FINN, 2000: 297). Poderíamos acrescentar que as mesmas fontes também confinam sua atenção ao mundo urbano ${ }^{84}$.

Se nos fiarmos pelos Atos dos Apóstolos, o cristianismo chega a Antioquia não por uma iniciativa missionária lúcida e livre, mas com a fuga de membros da comunidade hierosolimita diante da perseguição desencadeada após a lapidação de Estêvão na cidade sagrada dos judeus (Atos 11,19), o que é bem plausível ${ }^{85}$. Do mesmo modo, por mais que seja difícil para a maioria dos estudiosos aceitar ${ }^{86}$, não há qualquer evidência de peso para a existência de uma comunidade cristã em Alexandria já no século I d.C ${ }^{87}$. A própria Ásia só teria sido alvo de evangelização sistemática na terceira viagem de Paulo, e nesse ponto os Atos parecem oferecer uma informação fiável. A desculpa para o apóstolo não ter se dirigido para lá logo na segunda viagem (quando chega à Macedônia e à Grécia) é o impedimento por parte do Espírito Santo: "Atravessaram depois a Frígia e a região da Galácia, impedidos que foram pelo Espírito Santo de anunciar a palavra na Ásia" (Atos 16,6). Misteriosamente, a Ásia deveria ser alcançada apenas posteriormente. Quereria a passagem indicar a ação de alguma profecia no desvio de rota? Ou é simplesmente um meio pelo qual o autor busca explicar de forma curta e breve o que, para ele, seria

\footnotetext{
${ }^{83}$ Richard L. Rohrbaugh, analisando as tradições sobre Jesus, mostra como o Evangelho de Marcos, uma das bases para todos os futuros escritos sobre o profeta nazareno, tem presente em seu relato grupos e ambientes marcadamente rurais, ainda que o ambiente urbano não esteja ausente. Ver ROHRBAUGH, 2000: 200-8.

${ }^{84}$ Frank Trombley sugere que haveria certa dificuldade para o cristianismo adentrar as regiões eminentemente rurais do Mediterrâneo romano, onde o culto aos deuses era visto como sendo fundamental para a manutenção do ciclo natural ideal, com boas colheitas e poucos fenômenos naturais destrutivos (TROMBLEY, 2006: 311).

${ }^{85}$ Mesmo Koester, sempre desconfiado do relato lucano, aceita a veracidade do relato dos Atos dos Apóstolos sobre as circunstâncias da fundação da comunidade cristã em Antioquia (KOESTER, 2012: 106). ${ }^{86}$ Veja-se, por exemplo, a afirmação paradoxal da Koester: "Infelizmente, não existem evidências diretas para os primórdios do cristianismo no Egito, não obstante haver poucas dúvidas de que a missão cristã chegou a Alexandria durante o século I d.C.” (KOESTER, 2012: 239).

${ }^{87}$ Uma única possível pista para a existência de uma comunidade cristã em Alexandria é a proveniência, alegada pelos Atos dos Apóstolos, do missionário Apolo da capital egípcia (Atos 18,24). Devemos notar, porém, que o fato de um missionário cristão ser oriundo de Alexandria não significa, necessariamente, a presença do cristianismo na metrópole já em meados do século I d.C. O caráter itinerante de Apolo, constatado tanto pelos Atos quanto por 1Coríntios (1Coríntios 3,5; 16,12), é uma forte sugestão em contrário, inclusive abrindo a possibilidade de uma conversão sua em outra localidade, como no caso de Paulo.
} 
incompreensível se colocado de outra forma? Certamente são perguntas que apenas podemos sugerir e para as quais poucas respostas fundamentadas podemos imaginar ${ }^{88}$.

Nesta subseção, tratamos dos caminhos de difusão do cristianismo pela Ásia Proconsular no século I d.C. O enfoque será, primariamente, o geográfico. Abordamos a difusão social, ou seja, as camadas sociais que são abrangidas pela pregação e que vêm a compor as comunidades cristãs, em uma subseção própria ${ }^{89}$.

Se há algo que é deixado bem claro pelos Atos dos Apóstolos, e que se aparenta bastante plausível conforme a documentação posterior, é que a porta da pregação cristã na província asiática foi Éfeso, sua metrópole em ascensão à época, como visto no capítulo $1^{90}$. A fonte insiste bastante nesse ponto, inclusive retratando, de forma particularmente representativa, o apóstolo alcançando a metrópole asiática para nela pregar (ainda que, como veremos, já houvesse por ela passado anteriormente, mas sem delongas) pelo interior montanhoso, isto é, atravessando a Galácia e a Frígia (FITZMYER, 1998: 642), com nenhuma referência a qualquer evangelização de sua parte em cidades-chave localizadas no caminho e que, algumas décadas depois, possuem comunidades cristãs documentadas (como Filadélfia, por exemplo):

Passado algum tempo, [Paulo] partiu de novo [de Antioquia] e percorreu sucessivamente a região da Galácia e da Frígia, confirmando todos os discípulos. (...) Enquanto Apolo estava em Corinto, Paulo, depois de ter

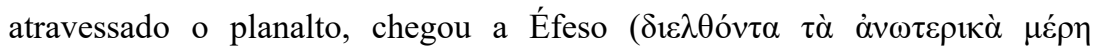
$[\kappa \alpha \tau] \varepsilon \lambda \theta \varepsilon \tilde{v} v \varepsilon i \varsigma$ ”Е $\varphi \varepsilon \sigma o v)$. (Atos 18,23; 19,1)

A escolha por Éfeso é bastante interessante: havia outros portos na província que poderiam servir para o mesmo fim de expansão da fé e, possivelmente, conexão marítima estratégica com as igrejas da Acaia e da Macedônia, como Esmirna e Mileto, por exemplo.

\footnotetext{
${ }^{88}$ Paulo faz referência, em Gálatas, a uma enfermidade da qual teria sido acometido quando de sua estadia na Galácia, na qual coloca a conta de sua decisão de pregar na região: "Bem o sabeis, foi por causa de uma doença que eu vos evangelizei pela primeira vez" (Gálatas 4,13). Não é possível se dizer, no entanto, se existe alguma relação, para o autor de Atos, entre tal enfermidade e a ação do Espírito Santo. Fitzmyer comenta que, no itinerário da segunda viagem missionária, Paulo e seus companheiros poderiam ter querido chegar a Éfeso pela estrada romana destinada especialmente à circulação de correspondências, tendo em vista a posição da cidade como sede do governador da província (FITZMYER, 2010: 578). Não oferece, porém, nenhuma hipótese para a "prevenção do Espírito" de uma entrada imediata de Paulo na Ásia.

${ }^{89}$ Uma narrativa concisa acerca da expansão do cristianismo através da missão de Paulo pode ser encontrada em MITCHELL, 2006: 108-121.

${ }^{90} \mathrm{Na}$ afirmação de Koester, "Lucas, o autor de Atos, intencionou escrever o capítulo sobre a atividade de Paulo em Éfeso como o último e mais esplêndido evento na atividade missionária do apóstolo" (KOESTER, 1995: 126).
} 
No entanto, a pólis efésia encontrava-se em pleno desenvolvimento econômico, com um papel preponderante na política local e com uma atividade comercial notável, além do ritmo de construção de novos edifícios, públicos ou não, que certamente serviria de ocupação para muitas pessoas. Em outras palavras, Éfeso, como um centro urbano eminente em termos de fluxo de pessoas na província, era uma porta perfeita para expandir o cristianismo não apenas na própria pólis, com sua grande população, como pelo interior da província ${ }^{91}$. De fato, vimos como a metrópole era consideravelmente bem posicionada geograficamente, assim como favorecida também por uma política efetiva de manutenção de sua conectividade com as outras cidades da província e com todo o interior da Ásia Menor, chegando mesmo aos limites orientais do império.

No entanto, apesar de a chegada missionária de Paulo em Éfeso se dar via Anatólia, é na conectividade da cidade pelo mar (sempre ele) que os Atos depositam a razão de sua escolha providencial para ser a porta da Ásia para o cristianismo. Neles, está dito que os primeiros cristãos (ao menos o que seu autor considera como cristãos) a alcançar a província teriam sido Paulo e o casal Priscila (chamada também de "Prisca" em Romanos 16,3) e Áquila, advindos de Corinto e a caminho da Síria por mar, ao menos no caso do apóstolo (Atos 18,18-19). Após uma entrevista rápida com os membros da sinagoga local (da qual não existem outras evidências explícitas além do próprio texto dos Atos), Paulo segue viagem para Antioquia, após mais uma viagem bem-sucedida, na qual havia fundado comunidades cristãs em centros urbanos importantes da Grécia e da Macedônia, como Filipos, Tessalônica, Atenas e Corinto, um dos principais portos do Egeu. Ao seguir para a Síria, porém, o apóstolo deixa em Éfeso o casal que o acompanhava: essa é a explicação dos Atos para a chegada de Prisca e Áquila na metrópole, recebendo em sua casa parte da comunidade cristã da cidade, conforme atestado pelo próprio Paulo na 1Coríntios, escrita em Éfeso (1Coríntios 16,8.19). No entanto, o casal não é retratado pelo autor como devotado à pregação, mas apenas como frequentadores da sinagoga local (Atos 18,26). O protagonista é sempre Paulo, que inicia os trabalhos em seu retorno da Síria, o que causa certa estranheza, uma vez que nenhuma outra razão é dada para que eles deixassem sua casa e seu trabalho em Corinto para se mudar de forma relativamente permanente a Éfeso (desconhecemos os motivos por trás de seu retorno a Roma, sua cidade de origem, conforme atestado em Romanos 16,3).

\footnotetext{
${ }^{91}$ Harnack chegou a destacar o sucesso da missão de Paulo em Éfeso nos seguintes termos: "Sua atividade fez de Éfeso a terceira capital do cristianismo, a capital verdadeiramente grega, e por um tempo parecia que ela se tornaria a capital definitiva e o centro" (HARNACK, 2004: 110).
} 
Os primórdios do cristianismo em Éfeso e na Ásia são representados pelo autor de Atos como já marcados pela diversidade, embora não seja uma diversidade exatamente aceita. Antes do retorno de Paulo, Prisca e Áquila, frequentando a sinagoga, encontramse com um judeu alexandrino chamado Apolo, crente em Jesus, mas que, conforme o relato, conhecia apenas o batismo de João. A fim de aperfeiçoar sua fé e inseri-lo mais perfeitamente no cristianismo (no caso, o paulino), o casal o chama à parte e o corrige. Apolo aceita a correção prontamente e é munido pelos mesmos de uma carta de recomendação para alcançar Corinto e aí trabalhar para a difusão da nova fé, mesmo tendo a cidade sido já foco das atividades de Paulo (Atos 18,24-28). Por outro lado, alcançando o apóstolo a metrópole da Ásia, defronta-se com um grupo de "discípulos" (a forma como, geralmente, o autor se refere aos cristãos) que, acreditando em Jesus como sendo o Messias, não havia recebido outro batismo que não o de João (nenhuma ligação é feita pelo texto entre tal grupo e Apolo). Paulo trata imediatamente de suprimir tal diferença, batizando-os novamente de modo a receberem o Espírito Santo:

Ali [em Éfeso] encontrou alguns discípulos ( $\mu \alpha \theta \eta \tau \dot{\alpha} \varsigma)$ e perguntoulhes: "Recebestes o Espírito Santo quando abraçastes a fé?" Eles responderam: "Mas nem ouvimos dizer que haja um Espírito Santo". E ele: "Em que batismo fostes então batizados?" Responderam: "No batismo de João ( $\tau$ ò 'I $\omega \alpha ́ v v o v$

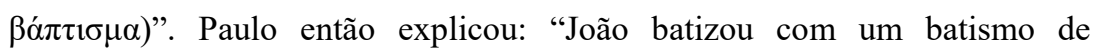
arrependimento ( $\beta \alpha \dot{\pi} \tau \tau 1 \sigma \mu \alpha \mu \varepsilon \tau \alpha v o i ́ \alpha \varsigma$ ), dizendo ao povo que cresse naquele que viria após ele, a saber, em Jesus". Tendo ouvido isto, receberam o batismo

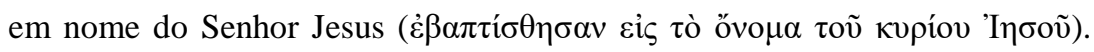
(Atos 19,1-5)

Por mais que a abordagem do apóstolo seja representada como conciliadora e mesmo compreensiva, uma vez que o batismo de João tinha, para o autor, parte na história da salvação efetuada por Jesus (Lucas 3,1-18), o zelo pela expansão do evangelho não comportava espaço para a manutenção de vínculos com o antigo círculo do Batista: seus membros precisavam ser, na perspectiva de Lucas (e na de Paulo, se aceitarmos a historicidade do relato), incorporados à corrente principal do cristianismo, representada pelo apóstolo Paulo (FITZMYER, 1998: 642). A diversidade, de fato, não costuma ser exatamente uma constante no livro dos Atos. Quando existe, como no caso citado e no da querela acerca da circuncisão em Antioquia e Jerusalém, nunca é causa de divisão perpétua entre grupos, que passam a seguir caminhos diferentes, mas sim conflitos que 
encontram sua solução em uma decisão de autoridade: os apóstolos e os "anciãos" ( $\pi \rho \varepsilon \sigma \beta v ́ \tau \varepsilon \rho \circ \imath)$ em Jerusalém decidem pela não-necessidade de se exigir a circuncisão dos convertidos não-judeus (Atos 15,1-35); em Éfeso, Prisca e Áquila ensinam a Apolo o que lhe resta aprender para difundir corretamente a fé em Jesus, ao passo que Paulo age para que os discípulos batizados apenas pela água de João Batista sejam agora iniciados pela recepção do Espírito Santo. Suprime-se para se garantir a unidade ${ }^{92}$.

A partir daí, Éfeso passa a ser, aparentemente, uma espécie de QG para Paulo (FITZMYER, 1998: 636; MURPHY-O’CONNOR, 2013: 145-174). Embora os Atos não o relatem, sabemos pelas suas cartas aos cristãos de Corinto que, da metrópole asiática, o apóstolo despacha cartas e pessoal para as igrejas da Grécia e da Macedônia, assim como faz visitas-relâmpago às mesmas, conforme seja necessário, principalmente no caso de ocorrência de fortes divisões internas (às quais também o autor dos Atos não faz referências). Assim ocorre com a 1Coríntios, explicitamente escrita de Éfeso (1Coríntios 16,8). Nela, vemos que Paulo utiliza a alta conectividade entre a metrópole da Ásia e as cidades da Grécia e da Macedônia para manter-se informado do que ocorre nas comunidades cristãs por ele aí fundadas: “Com efeito, meus irmãos, pessoas da casa de

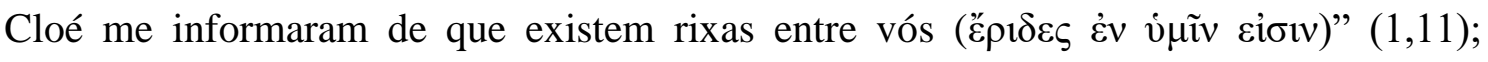
"Regozijo-me pela presença de Estéfanas, Fortunato e Acaico, pois supriram a vossa ausência; tranquilizaram o meu espírito e o vosso" (16,17). Daí também faz direcionamentos práticos, com a organização de uma coleta de dinheiro tendo por objetivo sanar a pobreza dos cristãos de Jerusalém (16,1-4), assim como envia auxiliares seus para representá-lo, ainda que temporariamente, nas igrejas de outras localidades (16,10-12). Existem evidências, contudo, de que ainda durante os cerca de dois anos que o apóstolo permanece em Éfeso, o cristianismo já alcança outras cidades da própria Ásia (KOESTER, 1995: 121). "Saúdam-vos as igrejas da Ásia” (1Coríntios 16,19), diz ele aos cristãos de Corinto. A respeito desse trecho, diz Trebilco:

Further, Paul here seems to imply (although we cannot put it more strongly than this) that the Christian community of Ephesus was the central Christian community of the province, since greetings are given from the churches of the whole province. This suggests that the Ephesian Christian community was a missionary centre, and maintained contact with Christians in

\footnotetext{
${ }^{92}$ Sobre conflitos e solução de conflitos nas primeiras décadas do cristianismo, cf. DESTRO e PESCE, 2010: $213-242$.
} 
others parts of the province. This would not be surprising, given the location and significance of the city of Ephesus. (TREBILCO, 2004: 71)

Não é possível contabilizarmos quantas cidades são alcançadas, mas podemos presumir que a conectividade existente entre Éfeso e os outros centros urbanos asiáticos, em conjunto com o grande afluxo de pessoas para a metrópole da Ásia poderia ter um papel na difusão do cristianismo por outras cidades costeiras e pelas existentes no interior.

Duas cartas, uma seguramente paulina e outra provavelmente pseudepígrafa, podem servir-nos de imagem a esse respeito: são elas, respectivamente, Filêmon e Colossenses. Filêmon é particularmente digna de nota, um documento pequeno, mas de valor inestimável por ser um retrato raro de um efeito direto do cristianismo no cotidiano urbano e de sua utilização da alta conectividade entre os centros urbanos da província como meio de difusão da mensagem. Paulo está preso (Filêmon 1), muito provavelmente em Éfeso, em um caso que não nos é narrado pelo autor de Atos, mas que encontra-se aparentemente referido em suas cartas ${ }^{93}$. Onésimo foge de seu mestre cristão Filêmon, que parece estar à frente de uma igreja que se reúne em sua casa (1: "Paulo, prisioneiro de Cristo Jesus... a Filêmon, nosso muito amado colaborador... e à igreja que se reúne na

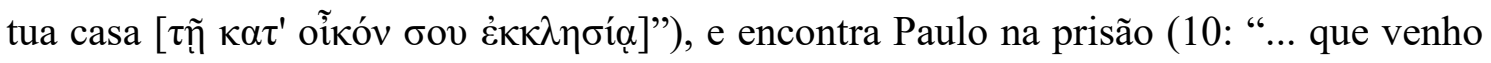

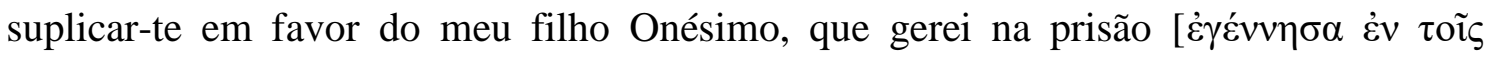
$\delta \varepsilon \sigma \mu$ oi $\varsigma] ")$. Sendo convertido ao cristianismo pelo apóstolo, é enviado de volta para a casa de seu senhor com uma carta de Paulo, pedindo (mas lembrando também que poderia ordenar-lhe) que o recebesse não mais como um escravo, ou seja, possivelmente dandolhe liberdade. No versículo 11, Paulo explicita a seu destinatário a nova condição e utilidade de Onésimo: “Outrora ele te foi inútil, mas doravante será muito útil a ti, como

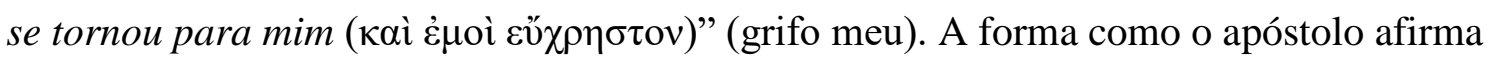
que Onésimo agora poderá ser "muito útil" a Filêmon parece indicar que ele deve ter se incumbido (ou ter sido incumbido por Paulo) de trabalhar para a propagação do cristianismo ai ${ }^{94}$.

\footnotetext{
${ }^{93}$ Ver, por exemplo, 2Coríntios 1,8-10: "Não queremos, irmãos, que o ignoreis: a tribulação que padecemos

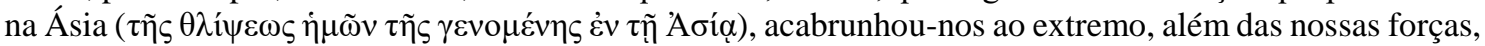

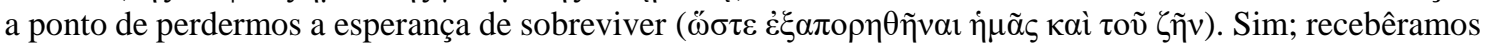
em nós mesmos a nossa sentença de morte, para que a nossa confiança já não se pudesse fundar em nós mesmos, mas em Deus, que ressuscita os mortos. Foi ele que nos libertou de tal morte e dela nos libertará; nele depositamos a esperança de que ainda nos libertará da morte". Sobre a possível prisão de Paulo em Éfeso, ver KOESTER, 1995: 122; MURPHY-O'CONNOR, 2013: 157-161; e TREBILCO, 2004: 83-7.

${ }^{94}$ Sobre a questão da escravidão em Filêmon e as leituras diferentes que podem ser feitas de seu texto, ver HARRILL, 2008: 522-6.
} 
Colossenses traz outra imagem: nela, conserva-se uma versão, possivelmente guardada pela tradição (KOESTER, 2012: 286), da difusão do cristianismo em Colossas, centro urbano médio da Ásia. Não é Paulo quem se incumbe pessoalmente de tal missão, mas um colaborador seu nativo da cidade, Epafras, o qual conhecera possivelmente em

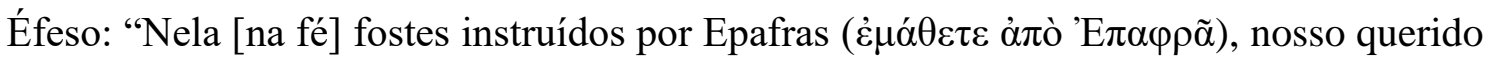

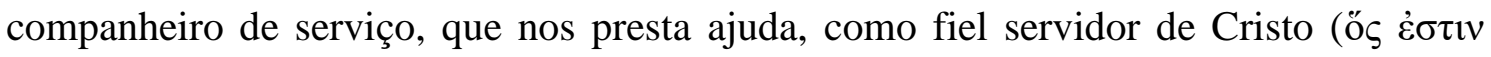

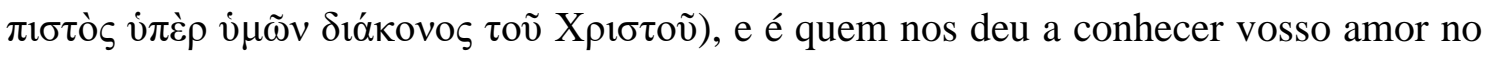
Espírito" (Colossenses 1,7). Em suma, embora certamente pudesse ter havido uma atividade missionária de Paulo de circular a Ásia, tendo Éfeso como sua base central, o mais provável, a partir dos indícios concedidos pela documentação, é que essa foi uma atividade incumbida sobretudo a seus colaboradores, ao menos em alguns casos nativos dos próprios centros urbanos asiáticos (MURPHY-O’CONNOR, 2013: 165). A utilização da metrópole asiática para esse fim seria, portanto, estratégica, em adaptação à sua cada vez mais privilegiada posição no quadro político-econômico regional.

Não é possível desenhar, por meio da documentação, um traçado certo para a difusão do cristianismo na província. Se ela dependesse do afluxo de pessoas a Éfeso, com as quais Paulo teria contato de alguma forma, dificilmente poderia haver uma racionalidade nos caminhos percorridos pela nova fé. Deste modo, é bem possível que centros urbanos de menor monta, como no caso de Colossas ${ }^{95}$, tivessem sido alcançados antes que outras grandes cidades da região, como Esmirna e Pérgamo. Em Colossenses, no entanto, existe um pedido por parte de "Paulo" para que sua carta seja lida também pelas comunidades cristãs presentes em Laodiceia e Ninfas, assim como para que sua carta enviada aos cristãos laodicenses (que alguns estudiosos chegaram a imaginar que fosse Efésios ${ }^{96}$ ) fosse lida pelos colossenses (Colossenses 4,15-17). É possível, portanto, que essa igreja tivesse sido alcançada ainda na época de Paulo e que a tradição a esse respeito tivesse sido conservada em Colossenses.

O Apocalipse de João, um documento não-paulino do fim do século I d.C., traz outra lista de igrejas às quais o Cristo se dirige, na visão de João (Apocalipse 2-3): Éfeso, Esmirna, Pérgamo, Tiatira, Sardes, Filadélfia e Laodiceia. Cinco novas cidades são citadas como tendo sido alvo de evangelização, e é de se notar que agora cidades de peso

\footnotetext{
${ }^{95}$ Raymond E. Brown observa que, das três cidades de maior destaque do vale do rio Lico, Colossas seria a que teria alcançado menor importância econômica e política, ficando atrás de Laodiceia e Hierápolis. Cf. BROWN, 1997: 599.

${ }^{96}$ A esse respeito, cf. KÜMMEL, 2004: 461-7; MOFFAT, 1918: 389-395.
} 
no quadro político-econômico façam parte do cristianismo asiático, como Esmirna, Pérgamo e Sardes. Não é possível dizer com certeza se essas são comunidades fundadas ainda na época de Paulo ou pela ação do próprio profeta João. No entanto, ao menos no que tange Esmirna, temos uma pista: em sua epístola aos cristãos filipenses, Policarpo de Esmirna louva a igreja destinatária, principalmente por ser mais antiga que a sua própria: "Pois ele [Paulo] exultou em vós dentre todas as igrejas, as quais sozinhas conheciam a Deus naquele tempo; pois nós ainda não o havíamos conhecido" (Pol.Filipenses 11,3; Trad.: EHRMAN, 2003: 349). Podemos fazer, no mínimo, duas leituras de tal informação: a) os cristãos de Esmirna, mesmo tendo sua comunidade fundada à época de Paulo, teriam guardado a memória de terem sido evangelizados após a passagem do apóstolo por Filipos; b) os esmirniotas guardavam a memória de não terem sido evangelizados à época de Paulo, mas em algum lugar entre mais ou menos o ano 70 e meados da década de 90 do primeiro século depois de Cristo, ou seja, após a morte do apóstolo. Embora ambas as visões tenham seu peso, a pouca dependência que demonstra Policarpo do material lucano (cujo evangelho não é citado por Pápias de Hierápolis, um autor cristão asiático contemporâneo seu) sugere-nos que poderiam existir poucas fontes à disposição do supervisor cristão que lhe fornecessem uma cronologia da fundação de comunidades por Paulo, sendo Atos a única conhecida no período (e, ainda assim, não citando Esmirna). Além do mais, no trecho citado, Policarpo parece reunir as igrejas fundadas por Paulo no grupo daquelas que "conheciam a Deus", das quais a de Esmirna é deixada de fora, provavelmente por não poder ser traçada até a época em que o apóstolo ainda vivia. A segunda opção, deste modo, parece ser mais plausível: Esmirna, no que pese sua ascendente importância política e econômica na região, teria sido alcançada somente após a morte de Paulo.

Desta forma, podemos concluir apenas um esboço de como poderia ter ocorrido a difusão geográfica do cristianismo pela Ásia: relativamente certo é que Éfeso tenha sido a porta de entrada. De fato, o destaque do grupo de cristãos presentes na metrópole dentre todos os outros da província é sugerido, simbolicamente, por uma ameaça feita pelo profeta João em nome de Cristo:

Devo reprovar-te, contudo, por teres abandonado teu primeiro amor. Recorda-te, pois, de onde caíste, converte-te e retoma a conduta de outrora. Do contrário, virei a ti e, caso não te convertas, removerei teu candelabro de sua 


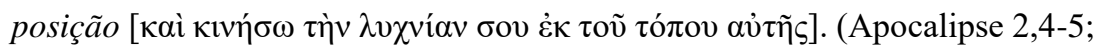
grifo meu)

A linguagem enigmática do Apocalipse de João nos impede de firmar um juízo definitivo e certo, mas é bem possível que o trecho destacado seja uma referência a uma posição especial garantida divinamente à igreja de Éfeso (YARBRO COLLINS, 2011: 845). Ao início do livro, João relata sua visão do Cristo em meio a sete candelabros de ouro $(1,12-13)$. O significado da visão é explicado pelo próprio Cristo: "Quanto ao mistério das sete estrelas que viste em minha mão direita e aos sete candelabros de ouro:

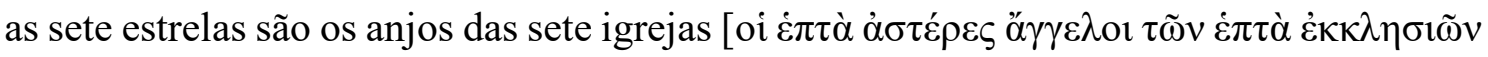

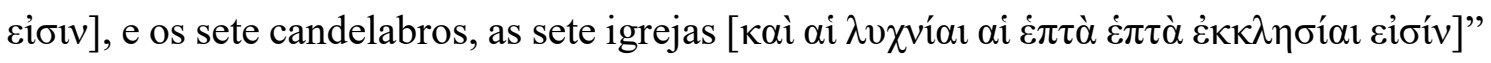
$(1,20)$. Quando o profeta afirma, em nome de Cristo, que Éfeso pode ter seu candelabro removido, é possível que esteja se referindo à ascensão de uma outra comunidade que pode tomar-lhe o lugar de honra por ser mais digna. Significativamente, a segunda igreja à qual se dirige o Cristo (logo após Éfeso, que é, não acidentalmente, a primeira) é aquela presente em Esmirna, para a qual não há nenhuma crítica, o único caso junto com Filadélfia $(2,8-11 ; 3,7-13)$. A comunidade cristã de Esmirna é pobre materialmente (“...

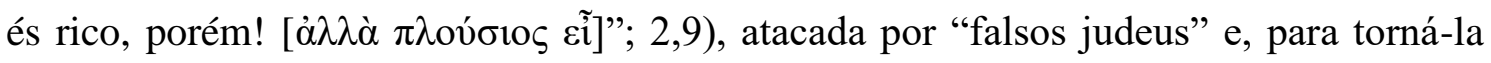
perfeita de vez, perseguida pelas autoridades locais. Aparentemente, João, que, provavelmente, inseriu as cartas no documento como um todo (ou seja, os cristãos de Éfeso provavelmente leram as palavras dirigidas aos de Esmirna), intencionalmente insere a igreja perfeita de Esmirna logo após a ameaça feita aos efésios com um objetivo muito claro: mostrar qual candelabro entraria no lugar privilegiado. Se, a essa época, como visto no capítulo 1, havia rivalidade entre as cidades asiáticas para se mostrar fieis ao poder imperial, faz todo o sentido que o profeta João instasse às igrejas a assumirem o mesmo ânimo competitivo com relação ao seu rei, Cristo. A predisposição e o costume já estavam lá; bastava a João dar-lhes forma e finalidade ${ }^{97}$.

\footnotetext{
${ }^{97}$ Existem diversas evidências de que o profeta João encontrava-se perfeitamente informado acerca de uma série de características marcantes da identidade e da memória das cidades a cujas igrejas ele escrevia. Em diversos momentos, ele se utiliza de seu conhecimento para envolver as sentenças do Cristo com certo aroma de familiaridade, de modo que as igrejas pudessem sentir individualmente a mensagem que lhes era dirigida. Colin J. Hemer dedicou todo um livro à análise de tal estratégia por parte de João (cf. HEMER, 2001), os resultados de sua pesquisa sendo de tamanha quantidade que não seria possível sequer fazer uma síntese aqui, com o risco de nos estendermos demais a respeito. Destacaremos alguns pontos levantados por Raymond E. Brown (BROWN, 1997: 783): 1) Em Apocalipse 2,7, a seguinte promessa é dirigida aos cristãos de Éfeso: “.... ao vencedor, conceder-lhe-ei comer da árvore da vida que está no paraíso de Deus”. Embora aqui haja uma referência clara à árvore da vida plantada no Éden (Gênesis 2,9), ela poderia também estar sendo citada por João aos efésios que sabiam que o grande templo de Ártemis havia sido construído
} 
De Éfeso, portanto, provavelmente se difunde o cristianismo pela Ásia. A partir da metrópole, a nova fé alcança setores do interior da província, possivelmente não obedecendo tanto a racionalidade quanto a oportunidade. Cidades como Colossas, Ninfas e Laodiceia veem comunidades cristãs serem fundadas antes que grandes centros urbanos, como Esmirna e Pérgamo. Não demora muito, porém, para que esses últimos sejam alvos do mesmo fenômeno. Quando Inácio de Antioquia atravessa a região, parando em Esmirna, duas outras cidades são acrescentadas ao rol: Magnésia e Trália. A forma como Inácio se dirige a essa última pode sugerir que sua fundação fosse recente, talvez nos últimos anos do século I ou mesmo na primeira década do século II d.C, como vemos no capítulo 3.

\section{3: Composição social}

Tão importante quanto a difusão geográfica do cristianismo é a sua difusão social, entre as camadas sociais que constituíam os centros urbanos. Fundamental para termos uma visão geral do cristianismo asiático do primeiro século depois de Cristo é a pergunta: quem eram os primeiros cristãos dessa província? Em que trabalhavam? Qual posição social (ou quais posições sociais) ocupavam? Devemos ter sempre em mente, antes de tudo, que nossas fontes sobre o cristianismo asiático são bem escassas; como seria de se esperar, também o são no que tange a composição social das primeiras igrejas.

Certamente o cristianismo no geral, em seu primeiro século de existência, não era constituído de grupos compostos de membros de um único extrato social ou profissão, como ocorria em muitas associações voluntárias que congregavam trabalhadores de um mesmo ofício, mesmo quando voltadas para um culto comum (MCCREADY, 1998: 63). Do mesmo modo, não eram, em geral, as primeiras comunidades cristãs compostas apenas por ricos ou pobres. Uma das fontes mais sugestivas a esse respeito é a chamada Carta de Tiago, um documento que se afirma escrito por certo Tiago ("Tiago, escravo de

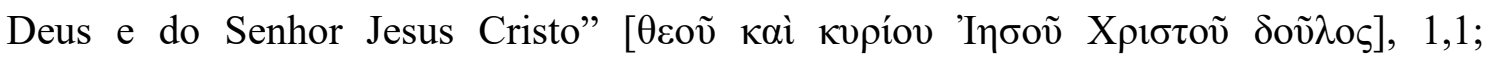

sobre um primitivo santuário, no qual encontrava-se uma árvore sagrada; 2) Pérgamo ser referida como o local do "trono de Satanás" $(2,13)$ é, muito provavelmente, uma caracterização altamente negativa feita pelo profeta do culto imperial, que tinha na cidade o seu principal sítio; 3) A ameaça do Cristo de chegar a Sardes como um ladrão em hora inesperada $(3,3)$ pode refletir a história da cidade, capturada duas vezes de surpresa; 4) O Cristo acusa a igreja de Laodiceia de ser "morna", o que o leva a querer vomitá-la de sua boca $(3,16)$, o que provavelmente atingia o ego de seus destinatários, uma vez que as cidades vizinhas de Hierápolis e Colossas eram conhecidas, respectivamente, pelas águas quentes destinadas ao banho e pelas águas geladas destinadas ao refrescamento. 


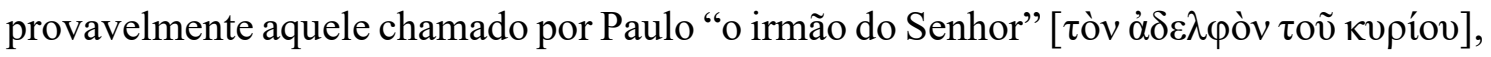
em Gálatas $1,19^{98}$ ), mas muito provavelmente pseudoepígrafo ${ }^{99}$ :

Meus irmãos, vossa fé em nosso Senhor Jesus Cristo de glória não deve

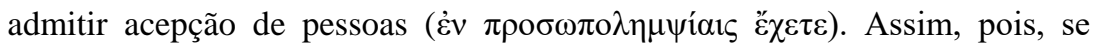

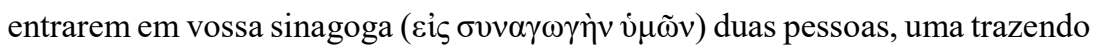

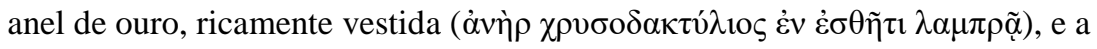
outra pobre ( $\pi \tau \omega \chi \grave{\jmath} \varsigma)$, com suas roupas sujas, e derdes atenção ao que se traja ricamente e lhe disserdes: "Senta-te aqui neste lugar confortável", enquanto dizeis ao pobre: “Tu, fica em pé aí”, ou então: "Senta-te aí, abaixo do estrado dos meus pés", não estais fazendo em vós mesmos discriminação? Não vos torneis juízes com raciocínios perversos. (Tiago 2,1-4)

Vemos, pela carta, que a diversidade social era um fato, pelo menos nas comunidades (ou sinagogas, seguindo literalmente o que é dito no texto) endereçadas pelo autor, possivelmente compostas sobretudo de judeus cristãos (HORRELL, 2000: 143-4). Isso a ponto de problemas serem gerados internamente, por conta da preferência dada a membros ricos, possivelmente responsáveis por pelo menos parte das despesas principais da igreja (auxílio aos em menor condição econômica, garantia de material para o culto, fornecimento de espaço reservado ao mesmo, etc.) ${ }^{100}$. O autor condena tal preferência como acepção de pessoas, e realmente não é difícil pensar que uma nova fé cujos vários ramos defendiam, em geral, uma visão social minimamente isonômica em vista do ideal do reino próximo, poderia ser também ambiente de tensão quando tais preferências

\footnotetext{
${ }^{98}$ Horrell diz que a opinião de que o Tiago do qual se reclama a autoridade na carta seria o "irmão do Senhor" é aceita pela maioria dos estudiosos (HORRELL, 2000: 143). Observando que o Tiago na carta se

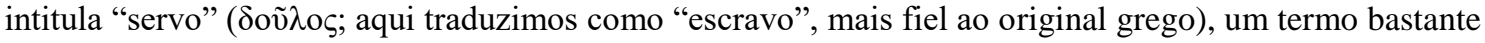
utilizado pelo cristianismo do século I para referir-se a dirigentes da igreja, assim como destacando o "tom inequivocamente autoritativo de toda a epístola", Thomas W. Leahy fica do lado da identificação "tradicionalmente aceita" e "em geral sustentada pelos biblistas modernos" de que o Tiago referido na carta é o líder da igreja de Jerusalém e irmão de Jesus (LEAHY, 2011: 667).

${ }^{99}$ Leahy destaca as seguintes razões para optar por uma pseudonímia no caso da Carta de Tiago (LEAHY, 2011: 668): 1) o excelente estilo grego da carta; 2) a falta de testemunho de sua canonicidade antes do séc. III d.C.; 3) indicações de uma data substancialmente posterior à vida de Paulo, enquanto Tiago teria morrido por volta de 62 d.C., quando o apóstolo ainda vivia; 4) a aparente ausência, na carta, de ensinamentos especificamente cristãos e de legalismo e ritualismo rigorosos vinculados, tradicionalmente vinculados à figura de Tiago. Embora diversos dos pontos levantados por Leahy sejam questionáveis, o fato de a carta trazer um grego bem trabalhado é incontornável, algo difícil de se esperar de alguém conhecido como o irmão de um carpinteiro do interior da Galileia. Horrell também a considera pseudônima, provavelmente escrita entre, mais ou menos, 75 e 100 d.C., mas apontando para a possibilidade de ela conservar tradições fundadas nos ensinamentos do próprio Tiago (HORRELL, 2000: 144).

${ }^{100}$ A partir do próprio texto, Stephen J. Friesen afirma que o autor esperava que sua audiência fosse composta de pessoas próximas do nível de subsistência, alguns destituídos de bens consideráveis e outros com condições de conservar algum excedente de sua propriedade ou atividade, mas nenhum membro advindo dos estratos mais ricos (FRIESEN, 2005: 247).
} 
ocorriam, as quais faziam patentes as diferenças entre o reino de Deus esperado e a ordem social vigente no Mediterrâneo romano. Stephen J. Friesen argumenta que, em vários trechos do texto, o autor se coloca em oposição a princípios básicos de todo o sistema sócio-econômico imperial (como a naturalidade da desigualdade econômica e social, por exemplo) e critica seus leitores por não se conscientizarem de que têm o dever de agir de forma contrária, de maneira não violenta mas não menos subversiva, com atitudes como a garantia do sustento dos mais pobres e a desconsideração das diferenças sociais no ambiente comum (FRIESEN, 2005: 244-7).

No entanto, embora seja um documento precioso no que tange a questão social no cristianismo do primeiro século depois de Cristo, a Carta de Tiago não concede nenhum dado específico e explícito das comunidades cristãs da Ásia, focos de nosso interesse. Uma fonte que poderia suprir-nos de tal tipo de informação seria o livro dos Atos dos Apóstolos, com sua narrativa acerca da evangelização de Éfeso. Muito pouco, porém, pode ser retirado dessa fonte. Em princípio, como já dito anteriormente, cabe um certo resguardo no que tange à confiabilidade da informação lucana: claramente o autor coloca informações em seu relato que possam apresentar um movimento cristão exemplar ao seu leitor. Isso inclui demonstrar, por meio da narrativa, que o cristianismo não era incompatível com nenhuma etnia e com nenhuma classe social ${ }^{101}$. Deste modo, apesar de a fé se iniciar com um carpinteiro galileu convocando pescadores para segui-lo e serem os primeiros líderes de seus futuros discípulos (Lucas 5,1-11), ela não deixaria de ser aceita por representantes legítimos da própria ordem romana, como o centurião Cornélio, de Cesareia Marítima, convertido por Simão Pedro (Atos 10), ou mesmo uma figura de alto escalão na administração romana, como Sérgio Paulo, procônsul de Chipre, que “abraçou a fé, maravilhado com a doutrina do Senhor" $(13,12)$, após ver o apóstolo Paulo (ainda chamado de "Saulo" pela narrativa) cegar o mago Elimas Bar-Jesus, com o poder conferido por Cristo. A nova fé, desta forma, é representada como oriunda de Jerusalém, mas destinada a alcançar Roma (MARGUERAT, 2003: 73), movimento esse que, para o autor, significa não só a transferência de uma cidade para outra (embora esta pudesse ser uma realidade para ele, com o fim catastrófico da Guerra Judaica, brevemente descrita pelo mesmo em uma profecia de Jesus no Evangelho; cf. Lucas 21,20-24), mas a aceitação

\footnotetext{
101 “Os relatos dos associados e convertidos paulinos no livro dos Atos devem ser usados com um pouco de cautela, pois foram escritos uma geração depois das epístolas de Paulo e dependem de tradições que podem ter sido distorcidas pelo tempo e pelos acidentes de transmissão. Além do mais, devemos lembrarnos de que o autor de Lucas-Atos evidentemente estava interessado em mostrar que a seita cristã obtivera o apoio de cidadãos estabelecidos e bem situados" (MEEKS, 2011: 143; grifo meu).
} 
por sua parte da ordem romana e a expectativa de que a mesma aja com reciprocidade. Roma é o instrumento final de Cristo e do Espírito Santo para que o evangelho alcance os confins da terra ${ }^{102}$, e isso envolve a compatibilidade do mesmo com todas as classes sociais, ainda que trazendo mudanças óbvias para sociedades urbanas que tinham em seus deuses a base de sua identidade e de sua atividade econômica, o que é representado narrativamente de forma particular pela revolta dos ourives em Éfeso. Fascinante é a forma como o autor resume esse último ponto por meio das palavras do artesão Demétrio, o instigador do movimento: a pregação de Paulo em Éfeso "não só traz o perigo de a nossa profissão cair em descrédito, mas também o próprio templo da grande Deus Ártemis

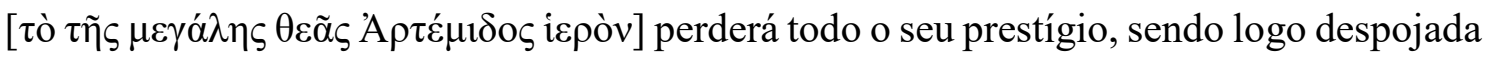
de sua majestade aquela que toda a Ásia e o mundo veneram" (Atos 19,27) ${ }^{103}$.

Como visto anteriormente, possuímos consideravelmente pouca informação sobre uma série de aspectos das comunidades paulinas da Ásia à época da passagem do apóstolo pela região, uma vez que não chegou até nós nenhuma carta sua à igreja de Éfeso ou a outras comunidades da Ásia, a menos que consideremos Colossenses como sendo de sua autoria. Dela tratamos mais à frente. $\mathrm{O}$ que se mostra possível de ser feito é uma observação de casos dos quais temos mais detalhes, de modo a iluminar um pouco a parca informação à nossa disposição. Um caso primordial para qualquer estudo acerca das primeiras comunidades cristãs de língua grega é o de Corinto, a partir das duas extensas cartas escritas por Paulo (sendo a segunda provavelmente um aglutinamento de duas ou três cartas menores; cf. MURPHY-O'CONNOR, 2011: 487-8).

O sociólogo Wayne A. Meeks se propôs esse problema em seu clássico $O s$ Primeiros Cristãos Urbanos: O Mundo Social do Apóstolo Paulo. Para tanto, ele evita utilizar-se de categorias como "classe" e "ordem", de modo a dar preferência a uma análise do status dos membros das comunidades paulinas, buscando abordar a questão de

\footnotetext{
${ }^{102}$ Marguerat sintetiza perfeitamente a intenção geral do autor dos Atos dos Apóstolos: "Aos olhos do autor de ad Theophilum, pois, o cristianismo representa o lugar onde se enlaçam as promessas de salvação feitas a um povo particular (Israel) e a universalidade de Deus que a missão cristã quer proclamar (dentro do Império e graças a ele). Uma nova leitura do conjunto Lc-At [Lucas-Atos] permitiria verificar, penso eu, que a lógica do pensamento lucano, com suas surpreendentes opções teológicas, está precisamente na ambição de configurar a identidade cristã por uma combinação de Jerusalém com Roma" (MARGUERAT, 2003: 89; grifo do autor).

${ }^{103}$ Fitzmyer sintetiza fantasticamente o objetivo do autor dos Atos dos Apóstolos com o relato da revolta em Éfeso e de sua conclusão, com um escriba da cidade recomendando que todos voltem para suas casas, de modo a não serem considerados agitadores da ordem pelos romanos (Atos 19,37-40): "The lesson that emerges is that Paul's preaching of the Christian message is not a contravention of the city's laws. On the contrary, the kind of opposition to his message that the silversmiths mount could jeopardize their own lives and status. The episode thus serves as another recognition of the legitimacy of Christianity" (FITZMYER, 1998: 655).
} 
para quem o cristianismo paulino seria atrativo e o porquê (MEEKS, 2011: 125-130). Por meio de um estudo prosopográfico, utilizando sobretudo as duas cartas aos cristãos coríntios e a dirigida aos romanos, Meeks sugere uma incompatibilidade de status de membros citados nominalmente nos documentos (Ibidem: 165-7), ou seja, pessoas que poderiam enfrentar problemas de sociabilidade em seus respectivos ambientes sociais por algum fator indelével de sua vida, como no caso de Erasto de Corinto, a quem Paulo

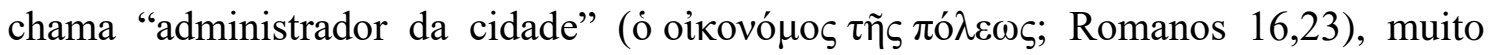
provavelmente o edil Erasto conhecido por meio de inscrições e acerca do qual existe uma grande possibilidade de que fosse um homem rico e de alto status cívico, mas também um liberto (Ibidem: 136-8) ${ }^{104}$. Poderia ser também o caso de um comerciante estrangeiro à cidade, vindo de outras paragens a ocidente e a oriente, sem possuir a cidadania e nem laços sociais fortes com quaisquer habitantes da localidade na qual havia fixado moradia. $\mathrm{O}$ cristianismo paulino, aquele que se difundiu primeiramente entre as cidades da Ásia, não só permitia, mas conduzia, por meio de sua ritualística (da qual tratamos na próxima subseção), o convertido a uma ressocialização quase completa, com novos laços sendo criados e um grupo com um sentido comunal muito forte, ao menos pelo que as cartas de Paulo deixam transparecer. Nas palavras de Meeks:

... a imagem do iniciado, adotado como filho de Deus, e que, assim, recebe nova família de irmãos e irmãs humanos, é uma forma cheia de vida de apresentar o que o sociólogo moderno poderia chamar de ressocialização de conversão. A estrutura de afinidade natural em que a pessoa nasceu, e que previamente definiu seu lugar e suas conexões com a sociedade, é aí superada por nova posição de relacionamentos. (Ibidem: 197)

Tal ressocialização era tamanha que permitia a convivência na comunidade de pessoas pertencentes a grupos sociais originalmente muito distintos. Desta forma, o novo grupo social dos cristãos paulinos tateava o ideal semiescatológico e radical pregado pelo apóstolo Paulo e que deixa transparecer em um famoso trecho de Gálatas:

\footnotetext{
${ }^{104} \mathrm{O}$ ponto da incompatibilidade de status, em conjunto com uma busca de maior socialização por membros melhor posicionados economicamente, toma destaque quando observamos, juntamente com Bruce J. Malina, que "simplesmente não havia qualquer número significativo de pessoas vindas das elites romanas" nos grupos cristãos anteriores a Constantino (MALINA, 2000: 384; tradução livre). Se tais pessoas buscavam um local ou grupo que lhes oferecesse melhores contatos com cidadãos do império melhor colocados, política e socialmente, as igrejas cristãs não estariam entre suas opções mais inteligentes.
} 
Chegada, porém, a fé, não estamos mais sob pedagogo; vós todos sois filhos de Deus pela fé em Cristo Jesus, pois todos vós, que fostes batizados em

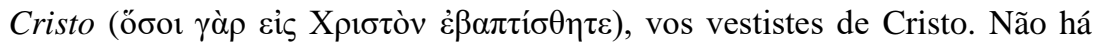
judeu nem grego, não há escravo nem livre, não há homem nem mulher (ov̉к

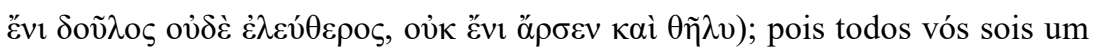
só em Cristo Jesus. (Gálatas 3,25-28; grifos meus)

Os efeitos práticos de tal ideal, que, possivelmente, espelhava a realidade escatológica próxima da ressurreição dos $\operatorname{mortos}^{105}$ (um tema caro a Paulo; vide 1Coríntios 15), eram a convivência lado a lado, nas reuniões, de pessoas de extratos sociais completamente distintos, por vezes ocorrendo de um escravo encontrar-se em uma ceia sagrada, por exemplo, ao lado de seu senhor, também cristão. Desta forma, soam surpreendentes as palavras do apóstolo a Filêmon, um cristão possivelmente possuidor de riqueza suficiente para ter escravos e uma casa em Colossas espaçosa o suficiente para receber reuniões cristãs (Filêmon 2), a respeito de Onésimo, seu escravo fugitivo:

Talvez ele tenha sido retirado de ti por um pouco de tempo, a fim de que o recuperasses para sempre, não mais como escravo, mas bem melhor do

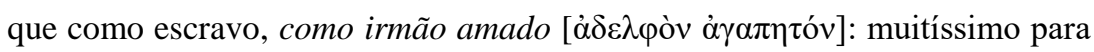
mim e tanto mais para ti, segundo a carne e segundo o Senhor. Portanto, se me consideras teu amigo, recebe-o como se fosse a mim mesmo. (Filêmon 15-17; grifo meu)

Não havia como, no entanto, se subverter totalmente as relações sociais que constituíam elemento essencial da pólis. Os posteriores escritos pseudopaulinos denotam tal paradoxo. Em Efésios 2,19, todos os endereçados pelo autor já não são "estrangeiros"

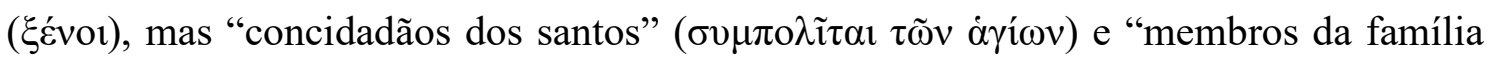

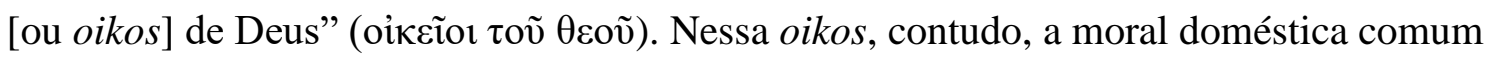
à pólis deveria ser respeitada, com mulheres submissas aos seus maridos e escravos obedientes aos seus senhores, ainda que existam exortações a que os últimos também

105 Compare-se, por exemplo, com o que se encontra dito em Marcos 12,24-25: "Jesus disse-lhes [aos saduceus]: 'Não estais errados, desconhecendo tanto as Escrituras como o poder de Deus? Pois quando ressuscitarem dos mortos, nem eles se casam, nem elas se dão em casamento, mas serão como os anjos nos céus"”. 
respeitem os primeiros, agora seus irmãos na nova realidade social. Essa é a lógica tanto em Efésios quanto em Colossenses (Efésios 5,21-6,9; Colossenses 3,18-4,1) ${ }^{106}$.

Do mesmo modo, os cristãos bem posicionados economicamente não deixavam de reter para si uma boa dose de relações patronais que outros pares seus poderiam tecer em outras associações voluntárias presentes na pólis (MEEKS, 2011: 177). Alguns, como Filêmon, tinham condições de disponibilizar sua casa para reuniões de culto cristão, como já visto anteriormente. É possível que, à época, pessoas como Filêmon possuíssem influência considerável na comunidade reunida em sua morada. Quando em Éfeso, Prisca e Áquila, os grandes companheiros de Paulo, reuniam correligionários em sua casa (1Coríntios 16,19); devemos recordar que os Atos os colocam como instrutores da fé para Apolo, um possível reflexo tradicional de seu trabalho de instruir a igreja à qual davam hospitalidade.

Um quadro social aproximado das primeiras igrejas da Ásia, portanto, poderia ser apresentado da seguinte forma: contava o grupo com membros advindos de classes e extratos sociais bem diversos, ressocializados voluntária e paradoxalmente em uma nova realidade que comportava tanto uma alteração nas relações tradicionais entre seus membros (homens e mulheres, escravos e senhores não eram mais essencialmente desiguais) como uma conservação das mesmas tanto para a manutenção da ordem interna, de modo a não ser causa de escândalo público, quanto para a garantia de espaço e material para rituais sagrados (relações de patronato). Tratando em termos de níveis sociais, existe uma tendência maior em se optar por um quadro social das primeiras igrejas da Ásia (em conjunto, normalmente, com as do resto do Mediterrâneo, embora tal generalização ocorra, normalmente, a partir da leitura do corpus paulino) no qual prevalecem fieis oriundos dos extratos médios, a partir de um ponto de vista econômico, embora em uma variedade cinzenta. "No quadro [social] faltam as extremidades superior e inferior da escala social greco-romana”, diz Meeks, acrescentando: “O cristão 'típico', contudo, aquele que na maioria dos casos marca sua presença nas epístolas [paulinas] por meio de um ou outro pequeno traço, é artesão livre ou pequeno comerciante” (MEEKS, 2011:

\footnotetext{
${ }^{106}$ Raymond E. Brown argumenta pela função importante das listas de deveres domésticos presentes em Efésios e Colossenses (embora focando-se no segundo caso) na inserção da comunidade cristã na pólis, o que exigia certamente a adoção de um comportamento cotidiano que servisse como vitrine para os nãomembros, tanto como meio de evitar hostilidades, como para chamar a atenção em vista de novas adesões: "In the maturing Christian communities believers needed guidance, so that outsiders could see the effect of Faith in Christ on their lives and recognize them as beneficial members of society. This need may have been more pressing when and where the majority of Christians were Gentiles who had not been raised with a knowledge of the Jewish Law" (BROWN, 1997: 608).
} 
165-6). Mesma opinião é a de Malina, ao referir-se aos destinatários de documentos cristãos anteriores a Constantino (incluindo Inácio de Antioquia): "The persons they adress are for the most part city merchants and craftsmen that are quite 'comfortable' for persons who are non-elites and often non-citizens" (MALINA, 2000: 384). Visões opostas, no entanto, devem ser recordadas: Friesen, a partir das cartas paulinas, enxerga comunidades cristãs cujos membros, em sua "esmagadora maioria", seriam "pobres, muito pobres ou desesperadamente pobres", ao passo que apenas alguns indivíduos citados por Paulo estariam em níveis de "recursos excedentes moderados" ou mesmo meramente "acima do nível de subsistência" (FRIESEN, 2005: 253-4). Em ambos os casos os membros em melhores condições econômicas encontrariam campo farto para o exercício do patronato em forma de "serviço" ou "fadiga" pelos "santos", embora obviamente o segundo caso, defendido por Friesen, permitiria um efeito social e simbólico maior para tal iniciativa.

\section{4: Ritual}

Existe um debate a respeito de se o cristianismo em seu primeiro século consistia em uma religião. O debate é controverso, a começar pelas fronteiras não muito claras (se existentes) entre cristianismo e judaísmo ${ }^{107}$. Um judeu cristão residente na Palestina, por exemplo, dificilmente concordaria com alguém que dissesse que ele não pertencia à mesma fé que os outros filhos de Israel: o que o distinguia de membros de outras seitas e facções judaicas era sua crença de que Jesus de Nazaré era o Messias e Filho de Deus, o verdadeiro rei de Israel, na descendência de Davi. Mesmo Paulo, apesar da interpretação corrente feita de suas cartas ao longo dos séculos, não teria rompido completa e definitivamente com Israel (embora outros judeus pudessem tê-lo por apóstata, considerando que ele mesmo afirma ter recebido punições condizentes, como o apedrejamento e os quarenta golpes menos um, que teria recebido três vezes dos "judeus"; cf. 2Coríntios 11,24). Essa é a tese da chamada "Nova Perspectiva sobre Paulo", capitaneada inicialmente por Ed Parish Sanders (ver SANDERS, 2009; ver também DUNN, 1998). Outro argumento existente que corroboraria a tese de que o cristianismo

\footnotetext{
${ }^{107} \mathrm{Um}$ trabalho clássico acerca das questões de identidade do cristianismo antigo e tardo-antigo, sobretudo com relação ao próprio judaísmo, é aquele assinado por Marcel Simon e intitulado, em sua tradução inglesa, Verus Israel: A Study of the Relations between Christians and Jews in the Roman Empire AD 135-425, publicado originalmente em 1964. No entanto, um retorno de peso ao tema foi feito, com grande sobriedade, por Judith Lieu, em Christian Identity in the Jewish and Graeco-Roman World, publicado pela Oxford University Press em 2004.
} 
mais antigo (fosse ele paulino, palestino, joanino, etc.) não constituía uma fé à parte é a falta do que seriam características próprias de uma religião à época, como construções de caráter minimamente monumental com uma função templária, um corpo de sacerdotes, que existiam mesmo em associações voluntárias voltadas para o culto de uma divindade, e um ritual sacrificial regulado (MEEKS, 2006: 159-160).

No entanto, a ponderação de Meeks continua sendo válida e convincente, utilizando testemunhos de escritores antigos não-cristãos a respeito do cristianismo e debatendo com E. A. Judge:

Na verdade, Plínio [o Jovem] não pensou no cristianismo como sendo constituído por "conclaves de rigoristas éticos", mas, sim, como "superstição perversa e descontrolada". É difícil compreendermos por que não só Plínio, mas também Tácito e Suetônio aplicariam o termo superstitio a uma sociedade que debatia assuntos éticos e que não possuía ritual algum. Usa-se este termo para caracterizar rituais praticados por alguém de quem não se gosta. Se os cristãos primitivos não fossem "perversos e descontrolados" ou, como Judge descreve, "uma novidade desconcertante", eles podiam ter sido chamados de religio. (MEEKS, 2011: 294)

O debate acerca de se o cristianismo do primeiro século poderia ser considerado, à sua época, uma religião é deveras complexo, uma vez que exige uma compreensão profunda acerca do que os antigos considerariam "religião", assim como as dificuldades de caráter fenomenológico de uma pesquisa moderna sobre religião lidando com visões greco-romanas a esse mesmo respeito, com todo o perigo anacrônico que isso comporta. No momento, mais que tal questão, importa-nos concluir se o cristianismo na Ásia contava com rituais em suas reuniões. Não se trata de uma mera questão de história das religiões, mas de um fenômeno social, no qual estão comportadas relações de poder e controle social em um determinado grupo. Antes, porém, é necessário que delimitemos o conceito de "ritual", que não se encontra presente explicitamente nas fontes que analisamos. Permaneçamos, ainda, em Meeks, com seu estudo influente acerca do cristianismo que temos em mente aqui:

Grande e crescente número de cientistas sociais definem o ritual como sendo uma forma de comunicação. Ele não só inclui certos padrões de linguagem; ele próprio é uma espécie de discurso, de palavra. Interpretar o 
ritual é, com efeito, tentar descobrir as regras de gramática e sintaxe de uma língua desconhecida. (MEEKS, 2011: 295)

Para nosso estudo, tal definição, ainda que boa, soa um tanto quanto insuficiente. O ritual é linguagem, mas uma linguagem com consequências sociais, que se utiliza, por exemplo, da organização espacial para reafirmar uma forma de ver o mundo e um ideal acerca da própria ordem social. Aqui, acabamos por nos aproximar conscientemente de uma abordagem durkheimiana acerca do que é o ritual. É importante termos em conta que o ritual é uma forma de linguagem, mas ele não é somente uma forma de transmissão de informação. Ele tem efeitos sociais ${ }^{108}$. Não significa dizer que os agentes rituais encontravam-se conscientemente criando uma simbologia falsa para esconder intentos de controle sobre determinado grupo; trata-se, antes, de termos consciência (e nunca esquecer) que o ritual não apenas reúne, em si, uma série de mitos e símbolos, mas que atende a determinados objetivos, entre os quais frequentemente se encontram a divisão hierárquica entre pessoas.

Tendo em conta tudo o que foi dito, preferiremos seguir a tendência de Meeks em considerar o cristianismo do século I d.C. como fenômeno religioso (o que nunca significará dizer que era um fenômeno independente e autônomo, apartado de seu ambiente judaico de origem), com uma série de rituais a ele inerentes, organizados sobretudo em torno da devoção a Jesus de Nazaré como filho ungido de Deus, o qual dizia Plínio, o Jovem, ser cantado pelos cristãos reunidos da Bitínia "como um deus" (“carmenque Christo quasi deo"; Epístolas 10.96,7). Isso inclui, também, o cristianismo asiático, fundado sobretudo com o trabalho missionário do apóstolo Paulo. Mas quais são os rituais praticados nas comunidades cristãs da Ásia Proconsular? Como sempre, nossa documentação é muito escassa para desenharmos todo um quadro do ritual e culto de qualquer igreja presente em alguma cidade do Mediterrâneo no século I d.C. Mesmo no século II d.C. as informações são preciosas, pois que raras ${ }^{109}$. Existem rituais dos quais

\footnotetext{
108 "Existem inúmeros problemas com a perspectiva durkheimiana. Para Durkheim, o ritual era capaz de realizar sua obra unicamente cometendo fraude benigna. O ator de um rito falava de "Deus" ou dos "deuses", mas Durkheim sabia que ele realmente queria dizer "sociedade". Não obstante, os seguidores de Durkheim preservam a visão muitas vezes esquecida nas interpretações modernas de mito e de ritual: o ritual não transmite somente nem primordialmente informação. Ele faz algo" (MEEKS, 2011: 296-7; grifo meu).

${ }^{109}$ No caso do século II d.C., o melhor documento para se ter uma imagem (ainda que embaçada) de um culto cristão antigo continua sendo a I Apologia, de Justino Mártir (I Apologia 61.65-67). Já foi aventada a ideia de que Justino teria feito uma passagem por Éfeso (ALTANER E STUIBER, 2010: 76), talvez baseando-se na citação que faz ele do Apocalipse de João em Diálogo com Trifão 81. No entanto, em
} 
temos algumas sombras nos documentos cristãos mais antigos, como aquele semelhante a uma ordenação, ao qual fazem referência tanto os Atos dos Apóstolos como as duas Cartas a Timóteo, envolvendo jejum e imposição de mãos:

E escolheram Estêvão, homem cheio de fé e do Espírito Santo, Filipe, Prócoro, Nicanor, Timon, Pármenas e Nicolau, prosélito de Antioquia. Apresentaram-nos aos apóstolos e, tendo orado, impuseram-lhes as mãos [ $\kappa \alpha \grave{~}$

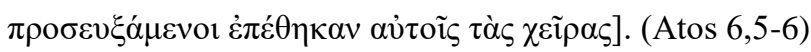

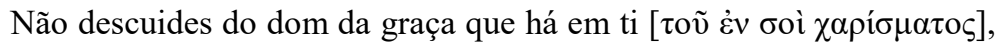
que te foi conferido mediante profecia, junto com a imposição das mãos do

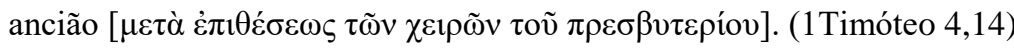

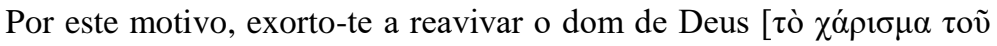

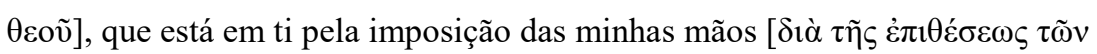
$\chi \varepsilon 1 \rho \tilde{\omega} v \mu$ ov]. (2Timóteo 1,6)

Não nos delongaremos, por enquanto, sobre a questão do rito de imposição das mãos. Focaremos, ao invés, naqueles dos quais possuímos maior volume de informação, sendo, possivelmente, os mais importantes da vivência religiosa comunal dos primeiros cristãos da Ásia: o batismo e a ceia sagrada. Serão, também, esses dois rituais os mais importantes no próximo capítulo, quando abordaremos propriamente as cartas de Inácio de Antioquia. Essas duas práticas, nas palavras de Meeks, "são tão largamente atestadas e tão cedo, que nós podemos dizer, sem exagero, que são constitutivas do movimento" (MEEKS, 2006: 160).

O batismo consistia em uma das principais heranças do movimento de João Batista existentes no cristianismo ${ }^{110}$, ainda que existissem, também, outros cultos mediterrânicos que lançassem mão do ritual do banho purificador (FERGUSON, 2009: 25-82; MEEKS, 2006: 161). Já citamos aqui o caso dos “discípulos” de Éfeso que, segundo os Atos dos Apóstolos, só conheciam o batismo de João, quando de seu encontro com o apóstolo

nenhum momento em seus escritos Justino diz explicitamente ter tido alguma passagem por Éfeso ou pela Ásia.

${ }^{110}$ Quanto à ligação entre os batismos joanino e cristão, vale ler o trecho do Evangelho de João no qual ocorre uma pequena discussão entre os discípulos de João Batista e um judeu anônimo, devido ao fato de Jesus conseguir batizar mais pessoas que o seu próprio mestre (João 3,22-26). Aparentemente, à época da escrita do evangelho, poderia haver uma disputa entre grupos de seguidores dos dois profetas (onde, exatamente, não se sabe, podendo ser em qualquer canto do Mediterrâneo oriental) sobre a importância maior ou menor de seus respectivos fundadores. Sobre o trecho citado, diz Perkins: "A referência a uma controvérsia sobre a purificação também é obscura. Ela talvez vise a levantar a questão do valor relativo do batismo de Jesus e do de João Batista, ainda que aquilo que se segue não fale diretamente da questão da purificação, mas sim sobre o êxito relativo dos dois homens" (PERKINS, 2011: 758). 
Paulo (ver seção 2.1). Obviamente, o batismo cristão trazia um desenvolvimento simbólico e teológico que ia consideravelmente além daquele pregado pelo Batista. Agora ele estava intimamente ligado ao enigmático Espírito Santo, que separava do resto do mundo os que aceitavam a mensagem cristã (MEEKS, 2006: 161). Decorrente do batismo e a ele inerente, desenvolvia-se uma antítese assimétrica: os cristãos não eram mais a mesma coisa que "os de fora”, e nem se encontravam no mesmo nível deles. Tal separação poderia ser mais ou menos radical, podendo ser medida na abertura maior ou menor à convivência com o ambiente externo da pólis: a 1Timóteo serve como um bom testemunho de como cristãos de Éfeso ligados à evangelização paulina poderiam manter uma identidade interna ao grupo muito forte, ao mesmo tempo que permitindo aberturas para interações sócio-culturais com o ambiente não-cristão (TREBILCO, 2004: 384); já o Apocalipse de João serve de evidência para a existência de grupos, representados por seu autor, que advogariam uma restrição maior a tais contatos como condição sine qua non para a fuga da idolatria e manutenção da fidelidade ao Deus de Israel e seu Cristo (Ibidem: 400-2). Ao menos no caso paulino, porém, o elemento mais forte acoplado ao ritual batismal é o seu caráter ressocializador. O novo membro encontrava-se inserido em uma nova realidade social que, ao menos no que esperava Paulo (e que transparece por suas palavras), deveria ser fonte de formação de novos laços fortes, análogos aos familiares, o que é representado pela própria forma de o apóstolo dirigir-se aos fieis: “... apresentamo-nos no meio de vós cheios de bondade, como uma mãe que acaricia os

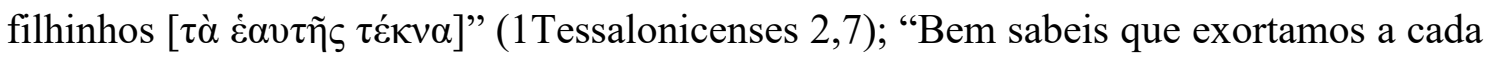

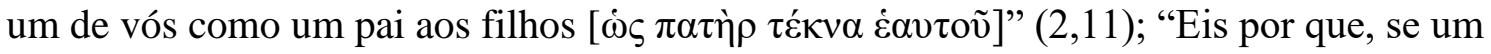

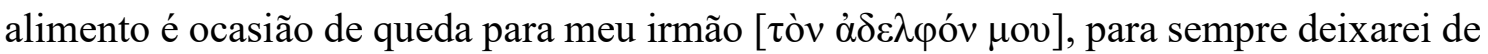
comer carne, a fim de não causar a queda de meu irmão” (1Coríntios 8,13); “... a fím de que o recuperasses para sempre, não mais como escravo, mas bem melhor do que como

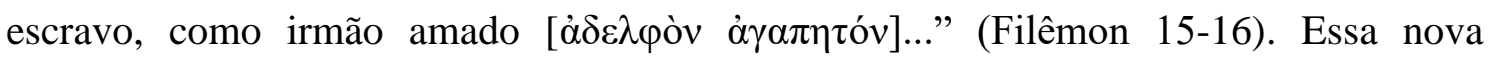
organização dos laços sociais é consequência direta da alteração, podemos dizer, violenta de vida proposta pela pregação, uma vez que é comparada com a morte, representada no batismo pela imersão:

Que diremos, então? Que devemos permanecer no pecado a fim de que a graça se multiplique? De modo algum! Nós, que morremos [ả $\varepsilon \varepsilon \theta \alpha ́ v o \mu \varepsilon v]$ para o pecado, como haveríamos de viver ainda nele? Ou não sabeis que todos

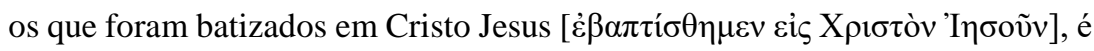


na sua morte que fomos batizados? Portanto, pelo batismo nós fomos

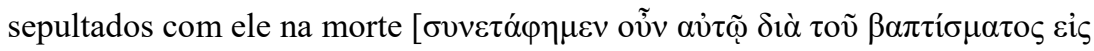

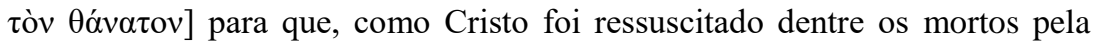
glória do Pai, assim também nós vivamos vida nova. (Romanos 6,1-4)

Se o batismo conferia a ressocialização de um indivíduo, a Ceia visava, sobretudo e ao menos no caso das igrejas paulinas, garantir a manutenção dos novos laços, por meio da simbologia da comunhão de todos com o Cristo, presente em corpo e sangue no pão e no vinho, assim como servia também à formação de fronteiras de diferenciação com relação ao mundo externo: "Eis por que todo aquele que comer do pão ou beber do cálice

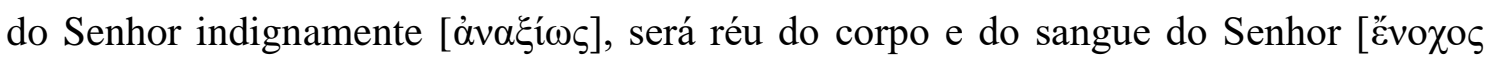

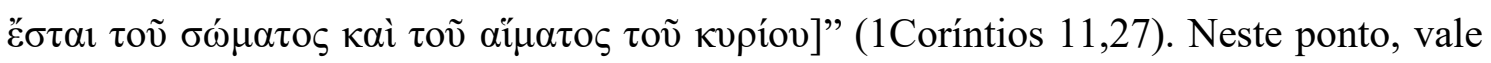
traçar um paralelo com outro documento cristão quase contemporâneo, a "Instrução dos Doze Apóstolos" (ou Didaché): "Não deixeis ninguém comer ou beber de vossa ação de

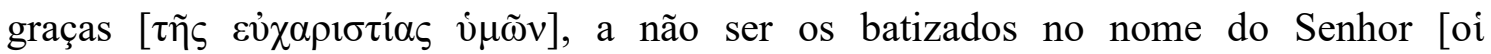

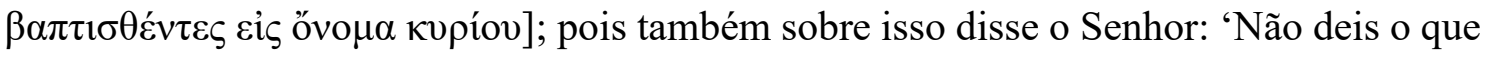
é sagrado aos cães"' $(9,5)$. A nova realidade social se manifestava no fato de pessoas de posições sociais consideravelmente diferentes se reunirem comumente em um único espaço doméstico, chamando-se, uns aos outros, de "irmão" ou "irmã". Nas palavras de Wayne O. McCready: "The community meal not only enhanced internal coherence, unity, and equality - it also set boundaries distinguishing community members from outsiders" (MCCREADY, 1996: 65).

Obviamente, um ambiente tal poderia dar vazão a situações paradoxais e excludentes: nem sempre um cristão rico se despojaria de todos os privilégios inerentes à sua elevada posição sócio-econômica, como vimos anteriormente espelhado na Carta de Tiago. Paulo enfrenta um problema como esse em Corinto, onde, aparentemente, os “irmãos" ricos se apressam a comer o manjar por eles levado à Ceia, de modo a não precisar compartilhá-lo com cristãos de posição social mais baixa:

Quando, pois, vos reunis, o que fazeis não é comer a ceia do Senhor; cada um se apressa por comer sua própria ceia; e, enquanto um passa fome [ $\kappa \alpha i$ ò $\varsigma \mu \grave{\varepsilon} \nu \pi \varepsilon ı \tilde{\alpha}]$, o outro fica embriagado. Não tendes casas para comer e beber? Ou desprezais a Igreja de Deus e quereis envergonhar aqueles que nada têm

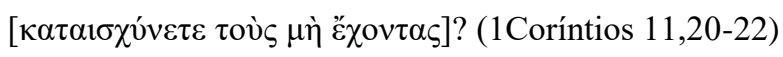


Não era fácil fazer com que pessoas que cresceram sob normas sociais tão claras e solidamente estabelecidas se acostumassem às novas regras de um período escatológico. Se Paulo se impacientava, é porque o tempo era curto; o fim estava próximo, e uma das funções da ceia sagrada era lembrar os discípulos deste fato: "Todas as vezes, pois, que comeis desse pão e bebeis desse cálice, anunciais a morte do Senhor até que ele venha

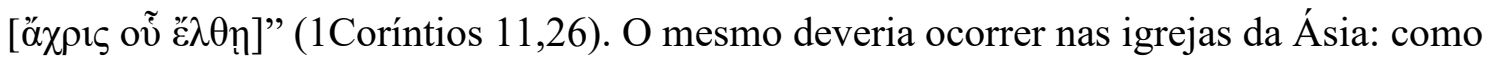
teria respondido Filêmon ao pedido de Paulo para que considerasse seu escravo como um irmão, sentando-se à mesma mesa e comendo da mesma comida? Certamente não haveria de ser um processo fácil, tendo-se em conta o tanto de convenções sociais que seriam, assim, quebradas.

Por outro lado, um culto cristão tão importante simbolicamente para o fortalecimento dos laços interpessoais em um determinado grupo não poderia deixar de representar uma porta para a manifestação da diversidade, sobretudo na de opiniões teológicas. Afinal, por razões práticas, raramente seria possível reunir todos os cristãos de uma mesma cidade em uma única casa ${ }^{111}$, para um culto único, embora haja indícios de que uma tal situação pudesse ocorrer em algumas circunstâncias; de fato, Gaio, de Corinto, é reconhecido por Paulo por hospedar a ele e a "toda a igreja" (ö $\lambda \eta \varsigma \tau \tilde{\eta} \varsigma$

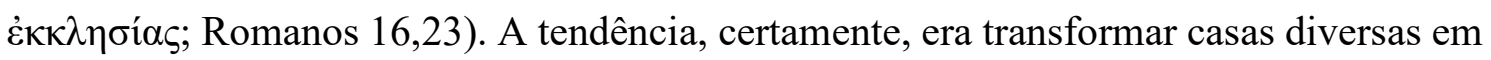
células-base para a organização de comunidades responsáveis pela organização e administração de seu próprio culto (TREBILCO, 2004: 95). Neste caso, poderia ocorrer de os laços entre os membros de um grupo reunido em local específico se mostrarem claramente mais expressivos do que aqueles entre toda a comunidade cristã da cidade. Aí, as diferenças teológicas poderiam ter o seu papel. Em outras palavras, a organização de uma igreja local em diferentes casas de reunião (a "igreja da casa de fulano") era um convite à diversidade teológica e ritual, assim como, possivelmente, de organização e de liderança.

\section{5: Lideranças e autoridade}

\footnotetext{
111 Trebilco traz, em uma nota, a farte discussão acadêmica a respeito de quantas pessoas poderiam ser acomodadas em uma reunião na casa de uma pessoa rica (considerando que tal seria preferível, no caso de estar à disposição da comunidade). Os números variam entre 30 e 75 pessoas em uma mesma reunião, o último caso sendo o de uma grande mansão. Trebilco também nota, sobriamente, que o crescimento do número de fieis afluentes a uma casa poderia crescer consideravelmente, havendo a necessidade de divisão do grupo em duas casas diferentes, o que seria, por sua conta, um quadro propício à formação de novas lideranças (TREBILCO, 2004: 98).
} 
Enfim, para arrematarmos o capítulo 2 e tomando tudo o que foi analisado até aqui, devemos nos voltar ao tema central da dissertação: as formas de autoridade e os quadros de liderança nas comunidades cristãs asiáticas como apresentados por documentos anteriores à passagem de Inácio de Antioquia pela província. Neste ponto, devemos destacar a pluralidade considerável de testemunhos acerca das lideranças cristãs na Ásia do século I d.C.: das cartas de Paulo, passando pelos Atos dos Apóstolos e alcançando as Pastorais, diferentes formas de divisão da autoridade comunal são atestadas e advogadas, o que, por si só, sugere um considerável dinamismo nas maneiras pelas quais o cristianismo da província buscou se organizar, principalmente no momento em que se via privado da liderança destacada do apóstolo Paulo. Deste modo, primando pela prudência, optaremos por fazer uma apresentação de quais são as formas de autoridade que os diferentes documentos defendem como sendo as ideais para a manutenção da unidade comunal e para a garantia da fidelidade dos cristãos aos princípios da fé.

\subsection{1: A época da atividade de Paulo}

Como visto logo na seção 2.4, uma das principais características do cristianismo nas áreas afetadas pela missão do apóstolo Paulo era a construção de um discurso, tanto textual quanto ritual (e mesmo gestual, como no caso do famoso "ósculo santo"; ver 2Coríntios 13,12), de ressocialização dos adeptos do Evangelho: os convertidos formavam uma comunidade nova, não delimitada e apartada espacialmente do âmbito da pólis, mas que guardava, em suas relações internas, uma diferenciação com relação ao mundo externo. No entanto, poderia ocorrer de outros convertidos acabarem sendo encarados como parte do "outro". Afinal, toda a vida comum do grupo transcorria no ambiente doméstico, onde a assembleia era reunida, ao mesmo tempo que era comum

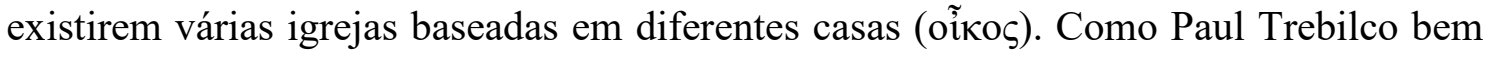
anota, a organização de igrejas em diferentes casas certamente favorecia a diversidade no cristianismo em uma mesma cidade (TREBILCO, 2004: 99). Lideranças eram necessárias, não só para prover o grupo em suas necessidades, mas também para garantir sua unidade e solucionar os conflitos internos.

No entanto, como já repetido várias vezes anteriormente neste capítulo, carecemos de testemunhos diretos com relação ao cristianismo asiático à época de Paulo também no caso das formas de liderança e a constituição de autoridades. Algo pode ser inferido de alguma parca informação presente em cartas dirigidas a igrejas presentes em outras 
cidades, assim como da pequena carta dirigida pelo apóstolo a Filêmon de Colossas. Para tanto, porém, de qualquer forma seria necessária uma comparação com o que sabemos de outros casos presentes nas cartas paulinas, em particular o que diz a 1Coríntios, um documento preciosíssimo para qualquer história social do cristianismo dos anos 50 do século I d.C.

1Coríntios é singular na medida em que, como resposta de Paulo a uma série de questionamentos que lhe haviam sido enviados por carta pelos cristãos coríntios $(\mathrm{cf} .7,1)$, apresenta-se não só como um retrato do pensamento do apóstolo a respeito de uma série de questões do cotidiano da comunidade, como também mostra-se como uma fonte indicadora dos problemas encarados por habitantes comuns de uma pólis que aceitaram se congregar em uma nova forma de associação religiosa, que trazia uma série de ideais e práticas fundamentais (mas não todas, como no caso da refeição sagrada) que muito provavelmente não lhe pareciam comuns. Como poderia ser afirmado que um homem condenado à cruz pelo poder romano havia ressuscitado corporalmente? Haveria a aceitação da fé cristã de implicar a negação de uma prática tão comum, como a refeição com carnes dedicadas aos deuses cultuados na cidade, parte mesmo de sua identidade? “O tempo se fez curto" (1Coríntios 7,29): se o fim de tudo estava próximo e todos seriam julgados por sua conduta, não seria melhor fazer como alguns filósofos populares, rejeitando engajar-se em casamento? Murphy-OConnor sintetiza bem o que está em jogo na comunicação entre Paulo e a igreja de Corinto:

Uma comunidade dividida não difere da sociedade pagã dividida, e sem a ressurreição Cristo não faz sentido. Se Paulo ignorasse tais pontos fundamentais, a igreja de Corinto acabaria por ser uma simples organização secular. (MURPHY-O'CONNOR, 2013: 180)

Um dos problemas a serem sanados pela carta de Paulo era a da divisão de funções na Igreja, no sentido coletivo singular, uma vez que algumas funções não estariam, como veremos a seguir, fixas a uma única comunidade. Uma vez que as reuniões em Corinto pareciam ser marcadas pela desordem total, do ponto de vista do apóstolo (“...vossas assembleias, longe de vos levar ao melhor, vos prejudicam"; 11,17), fazia-se necessário conhecer que parte cada um haveria de ter na mesma, assim como nas questões cotidianas da igreja. O critério, segundo Paulo, haveria de ser o reconhecimento dos dons conferidos 
pelo Espírito Santo a cada um, "o único e mesmo Espírito que isso tudo realiza, distribuindo a cada um os seus dons, conforme lhe apraz" $(12,11)$ :

Ora, vós sois o corpo de Cristo e sois os seus membros, cada um por sua parte. E aqueles que Deus estabeleceu na Igreja são, em primeiro lugar,

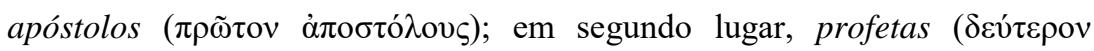

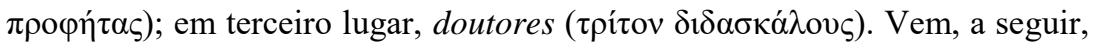
os dons dos milagres, das curas, da assistência ( $\dot{\alpha} v \tau \imath \lambda \eta \dot{\mu} \mu \varepsilon 1 \varsigma$ ), do governo

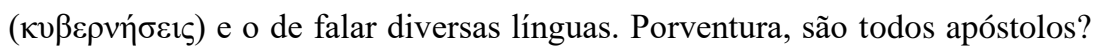
Todos profetas? Todos doutores? Todos realizam milagres? Todos têm o dom de curar? Todos falam línguas? Todos as interpretam? (12,27-30; grifos meus)

É notório, no trecho citado, que Paulo faz uma hierarquização clara entre dois grupos de membros da comunidade receptáculos de dons por parte do Espírito Santo: o primeiro é aquele composto por apóstolos, profetas e doutores; o segundo, o das pessoas que possuem dons gerais, mas não necessariamente aqueles que os tornariam aptos a tomar parte no primeiro grupo. "Os três primeiros dons, separados dos outros por estarem numerados e personalizados, constituem o triplo ministério fundamental da palavra através do qual a igreja é fundamentada e edificada", diz, sobre o trecho, MurphyO’Connor (MURPHY-O'CONNOR, 2011: 477). Dentro do primeiro grupo, é feita uma

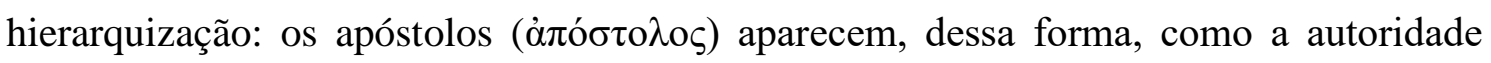
maior, como no caso do próprio Paulo. É a autoridade conferida pelo Espírito de fundar comunidades, por meio do anúncio do Evangelho ("Pois não foi para batizar que Cristo

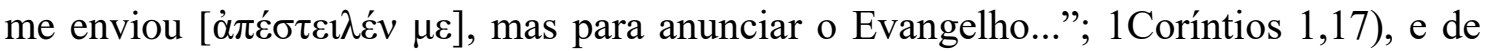
dirigi-las ("Quanto a mim, ausente de corpo, mas presente em espírito, já julguei... aquele que perpetrou tal ação...”; 1Coríntios 5,3), possuindo a prerrogativa de exigir delas o seu sustento ("Se semeamos em vós os bens espirituais, será excessivo que colhamos os vossos bens materiais?"; 1Coríntios 9,11), se assim o quiserem, e de delas exigir fidelidade, como servidores de Cristo e responsáveis por conduzir os fieis à nova vida redimida ("Que preferis? Que eu vos visite com vara ou com amor e em espírito de mansidão?"; 1Coríntios 4,21 112 ). Os profetas, conforme a própria 1Coríntios, possuem

\footnotetext{
${ }^{112}$ No caso da Ásia, vale notar a pressão autoritária que faz o apóstolo a Filêmon, exigindo dele um bom tratamento para o seu escravo Onésimo: "Eu, Paulo, escrevo do meu punho, eu pagarei... para não dizer

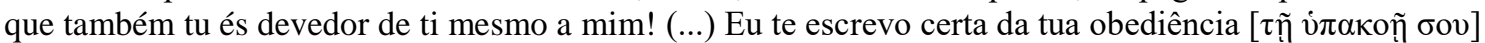
e sabendo que farás ainda mais do que te peço" (Filêmon 19.21). Uma clara intervenção de Paulo no plano privado de um ambiente doméstico, em sua condição de patrono espiritual de Filêmon.
} 
uma relação singular com o Espírito, embora estejam hierarquicamente abaixo dos apóstolos ${ }^{113}$ : por meio dele profetizam e exortam a comunidade ("Mas aquele que

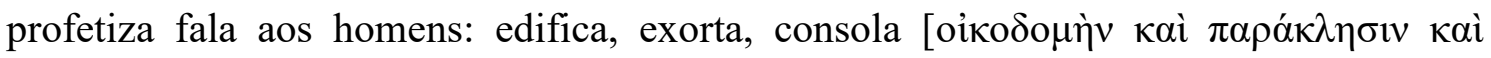
$\pi \alpha \rho \alpha \mu v \theta i ́ \alpha v] " ;$ Coríntios 14,3). O longo trecho de 1Coríntios 14 dá a entender que o ministério profético se dá, sobretudo (talvez exclusivamente), no âmbito da reunião comunal para o culto. Sobre os doutores, por outro lado, não é possível colher muita informação, embora seja altamente provável que sua função esteja vinculada à leitura e ensino das Escrituras (o Antigo Testamento) e do Evangelho anunciado pelo apóstolo fundador.

Uma fonte completamente independente da tradição paulina, a "Instrução dos Doze Apóstolos" (Didaché), sugere fortemente que a existência de apóstolos, profetas e doutores não é, nem de longe, uma característica única das igrejas fundadas por Paulo. Ao contrário, a forma como o documento aponta para uma série de atenções que os leitores devem ter quando alguém aparece afirmando exercer qualquer uma das ditas funções, indica que sua existência já era de pleno conhecimento do público por ele pretendido. Aí, o profeta aparece como uma autoridade singular, chamado mesmo de

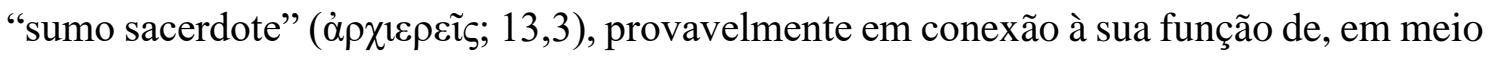
à reunião comunal, ser o responsável principal pelas orações dirigidas a Deus, destacando-se aquelas de ação de graças $(10,7)^{114}$.

O caráter itinerante de algumas das formas de serviço citadas por Paulo, do qual ele próprio era exemplo, não devia ser um fenômeno incomum no cristianismo de sua época, como a própria "Instrução" sugere no que se refere a apóstolos e profetas que porventura aparecessem. Em referência aos profetas, o documento diz: "Todo verdadeiro

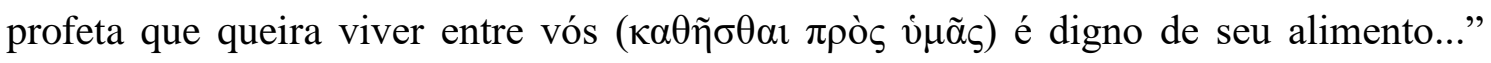
$(13,1)$, indicando que a fixação daquele encarregado da função profética era uma possibilidade, ainda que não necessariamente a regra. Na verdade, alguns dos evangelhos, como o de Marcos, parecem fazer referência apenas a um serviço itinerante de forma ideal, conforme as instruções dadas por Jesus a seus doze discípulos, na versão do autor:

\footnotetext{
${ }^{113}$ Outros documentos cristãos não-paulinos parecem indicar alguma espécie de contribuição financeira, coletiva ou individual, destinada a profetas dedicados unicamente ao seu ministério. Assim lemos em Mateus: "Quem recebe um profeta na qualidade de profeta, receberá recompensa de profeta" (Mateus 10,41). Também a Didaché: "Todo verdadeiro profeta que queira estabelecer-se entre vós é digno do seu alimento" (Didaché 13,1).

${ }^{114}$ A respeito da caracterização dos profetas cristãos na Instrução dos Doze Apóstolos, ver MILAVEC, 2003: 69-76.
} 
Chamou a si os doze e começou a enviá-los dois a dois. E deu-lhes autoridade sobre os espíritos impuros. Recomendou-lhes que nada levassem

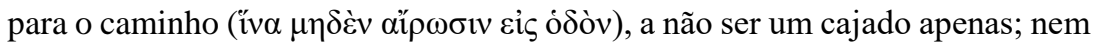
pão, nem alforje, nem dinheiro no cinto. Mas que andassem calçados com sandálias e não levassem duas túnicas. E dizia-lhes: "Onde quer que entreis

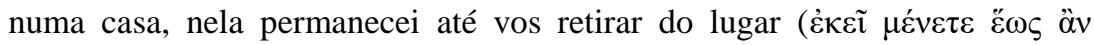
$\dot{\varepsilon} \xi \dot{\varepsilon} \lambda \theta \eta \tau \varepsilon \dot{\varepsilon} \kappa \varepsilon i ̃ \theta \varepsilon v)$. E se algum lugar não vos receber nem vos quiser ouvir ao partirdes de lá, sacudi o pó de debaixo de vossos pés em testemunho contra eles". Partindo, eles pregavam que todos se arrependessem. E expulsavam muitos demônios e curavam muitos enfermos, ungindo-os com óleo. (Marcos $6,7-13)$

Uma versão mais extensa das mesmas recomendações de Jesus existe em Mateus (Mateus 10), enquanto que o Evangelho de Lucas guarda uma versão muito similar à de Marcos (Lucas 9,1-6), talvez porque a segunda parte inteira da obra, os Atos dos Apóstolos, se preste a fazer uma idealização narrativa do que os evangelhos apenas apresentam em discurso. O Evangelho de Tomé também idealiza a mobilidade, mas em um sentido que vai além daquele dos casos citados até aqui: nele, ser itinerante não deve ser apenas uma marca característica daqueles dedicados ao serviço, mas do cristão em geral:

Jesus disse: “Tornai-vos transeuntes”. (Tomé 42; HENNECKE, 1963: 288)

Jesus disse: “Se vos disserem: 'De onde vos originastes?', dizei-lhes: 'Nós viemos da Luz, onde a Luz se originou por si mesma. Ela permaneceu e revelou-se em sua imagem'. Se vos disserem: 'Quem sois vós?', dizei: ‘Nós somos seus filhos e somos os eleitos do Pai Vivo'. Se vos perguntardes: 'Qual é o sinal de vosso Pai em vós?', dizei-lhes: 'É o movimento e o repouso"”. (Tomé 50; Trad.: Ibidem: 304, grifo meu)

Certamente que, no caso de 1Coríntios, não podemos fazer inferências diretas com relação ao caso da Ásia, uma vez que o documento trata da igreja presente em Corinto. Do mesmo modo, não há nada que indique que a "Instrução" deva ser conectada a qualquer uma das comunidades cristãs asiáticas. Os estudiosos, ao invés, têm já há um tempo tomado a posição majoritária de encarar esse documento como sendo de origem 
síria ou palestina ${ }^{115}$, embora mesmo os argumentos para tal tese não sejam tão sólidos, fundamentados, em geral, em uma suposta ligação com o Evangelho de Mateus (também localizado frequentemente na mesma região, mas, como visto anteriormente, a partir de pressupostos duvidosos). No entanto, é de se notar que Paulo afirma que as três funções destacadas hierarquicamente foram estabelecidas "na Igreja", e podemos inferir que aqui ele esteja utilizando de um coletivo singular. Em outras palavras, o apóstolo pressupõe a normalidade da existência de apóstolos, profetas e doutores em todas as comunidades cristãs ou transitando por todas elas, o que faria ainda mais sentido se não fosse ele o idealizador de tal divisão, mas apenas o receptáculo de uma tradição, oriunda, talvez, do próprio cristianismo palestino, o que a "Instrução" parece confirmar. A conclusão é a de que, muito provavelmente, era essa a hierarquia existente também nas igrejas da Ásia, que tinham em Paulo o apóstolo fundador. Isso é confirmado se quisermos que Efésios tenha alguma relação com o cristianismo asiático, sendo que essa carta pseudepígrafa apresenta uma lista semelhante à de 1Coríntios, embora um pouco inflada:

E ele [Cristo] é que concedeu a uns ser apóstolos, a outros profetas, a outros evangelistas, a outros pastores e doutores, para aperfeiçoar os santos em

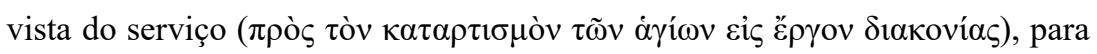

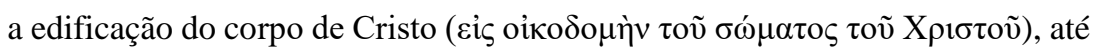
que alcancemos todos nós a unidade da fé e do pleno conhecimento do Filho de Deus, o estado do homem perfeito, a medida da estatura da plenitude de Cristo. (Efésios 4,11-13)

A partir de trechos como esses, desenvolveu-se, sobretudo a partir de meados do século XIX, uma tendência historiográfica afirmando o caráter puramente carismático da autoridade no cristianismo do primeiro século, ou seja, a inexistência de lideranças instituídas formalmente por um processo de escolha (seja por eleição ou por alguma decisão monocrática) ou por um regulamento interno. Apóstolos, profetas e doutores se destacariam naturalmente por seus dons, cabendo à comunidade unicamente o reconhecimento dos mesmos. Ainda seguindo essa tendência, haveria um processo, prolongado por décadas e alcançando meados do século II d.C., de substituição desse tipo de autoridade por uma outra de caráter mais institucional, com a formulação de meios de eleição de pessoas para o exercício de funções fixas, independentemente da manifestação

\footnotetext{
${ }^{115}$ Assim, por exemplo, ALTANER e STUIBER, 2010: 91; KOESTER, 2012: 174; MEIER, 1983: 81-4.
} 
espontânea de dons como a profecia e a habilidade para o ensino. Alguns historiadores e teólogos dedicados à história do cristianismo primitivo chegaram mesmo a identificar esse processo com a ascensão do que é comumente chamado "proto-catolicismo" (evidentemente, uma categoria histórica altamente vinculada à corrente de pensamento protestante). Em geral, o pressuposto ideológico e teológico por trás de tais trabalhos era o de que as Igrejas modernas deveriam se fiar pelo exemplo das comunidades cristãs mais antigas, anteriores ao processo de institucionalização que viria a desembocar no aparato de poder característico da Igreja Católica ${ }^{116}$. Abordamos melhor alguns autores ao fím do capítulo.

No entanto, uma leitura detalhada das cartas paulinas autênticas tende a favorecer o questionamento da linearidade do modelo explicativo clássico. De fato, alguns trechos apontam para uma valorização da administração comunitária, por vezes em conjunto com aqueles dons mais elevados, conforme elencados na parte citada de 1Coríntios. Note-se, nesse trecho, que (conforme grifamos na sua citação) alguns dos dons que o Espírito Santo pode conferir a um membro da comunidade são o da "assistência" e o do "governo". Certo é que, hierarquicamente, encontram-se em um rol abaixo daquele desfrutado pelos apóstolos, profetas e doutores. Por outro lado, outro trecho de 1Coríntios e ainda outro presente em 1Tessalonicenses indicam que Paulo dava mostras de grande simpatia por aqueles que exerciam tais funções na igreja e os recomendava fortemente aos outros membros da comunidade. Assim, diz ele em 1Coríntios 16,15-18:

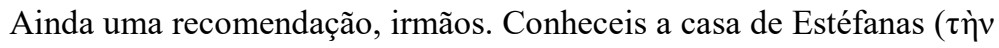
oikíav $\Sigma \tau \varepsilon \varphi \alpha v \tilde{\alpha})$, sabeis que são as primícias da Acaia e que se devotaram ao

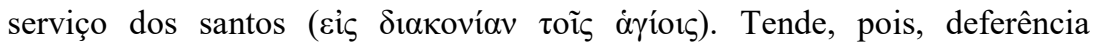
(

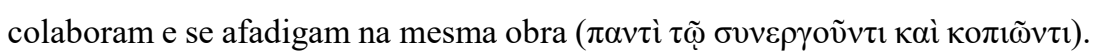
Regozijo-me pela presença de Estéfanas, Fortunato e Acaico, pois supriram a vossa ausência; tranquilizaram o meu espírito e o vosso. Sabei apreciar tais pessoas.

É interessante que Paulo considere preciso reafirmar a necessidade dos cristãos de Corinto de "ter deferência" por "irmãos" que "se afadigavam" por eles, em seu "serviço". Uma vez que outros pontos significativos da carta indicam que os coríntios não tinham

\footnotetext{
116 Para um quadro narrativo de fôlego do desenvolvimento da citada perspectiva historiográfica, ver
} BURTCHAELL, 1992: 61-179. 
quaisquer problemas com líderes como apóstolos, profetas e doutores (pelo contrário, davam-lhes valor até demasiado, na visão do apóstolo), o mais provável é que ele esteja se referindo a um grupo de pessoas que haveriam de ter recebido outro tipo de dom do Espírito. Uma vez que que seu "serviço" merece não apenas valorização, mas mesmo "deferência", o mais provável é que Paulo esteja referindo-se aqui a cristãos que dedicavam parte do seu tempo à assistência e/ou governo da comunidade. Nesse sentido, é notório que o primeiro referencial com relação a tal grupo seja a "família" ou "casa": Estéfanas, como provável cabeça de sua household, poderia manifestar as aptidões necessárias para guiar a comunidade, em conjunto com Fortunato e Acaico, embora não haja como sabermos se faziam parte da mesma casa. Por outro lado, Meeks nota a chamada do apóstolo pela "deferência" como uma ênfase necessária, na visão de Paulo, em uma comunicação com um grupo de cristãos que tenderia a dar pouco valor a tais pessoas se comparado com sua atitude frente àqueles que se mostravam capazes de tornar manifestos segredos divinos em línguas ocultas (MEEKS, 2011: 258-9).

O mesmo grupo de cristãos dedicados a "afadigar-se pelos santos" encontra-se em 1Tessalonicenses, considerada o documento cristão mais antigo de que se tem notícia:

Nós vos rogamos, irmãos, que tenhais consideração por aqueles que se

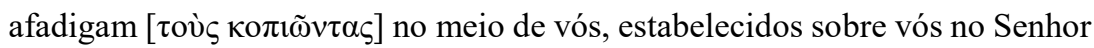

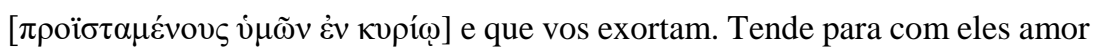

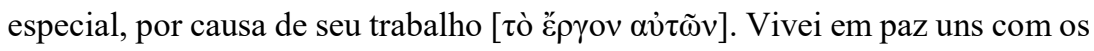
outros. (1Tessalonicenses 5,12-13; tradução livre)

Aqui, vemos que Paulo recomenda, pelos "que se afadigam" e que foram "estabelecidos no Senhor" sobre os fieis, um "amor especial", o que aparenta ser um paralelo com a "deferência" recomendada aos coríntios. Notemos que 1Tessalonicenses é um documento bem anterior a 1Coríntios, o que poderia explicar em parte, ao menos, as diferenças na linguagem empregada, mais afetiva no primeiro caso, mais direta e prática no segundo. A experiência do apóstolo poderia ter-lhe recomendado uma exigência maior nesse ponto para com os convertidos.

Pelos trechos citados, portanto, vemos que aqueles que se dedicavam à assistência e/ou ao governo da comunidade tinham em Paulo um considerável aliado para a afirmação de sua autoridade. Teriam eles alguma titulação comum, ou alguma forma pela qual eram referidos, sem precisar repetir que eram "os que se afadigavam"? Difícil dizer com 
certeza, mas Filipenses 1 pode ser indicativo que termos de referência aos mesmos existiam e eram comumente conhecidos, ao menos na igreja de Filipos, na Macedônia da época de Paulo: "Paulo a Timóteo, servos de Cristo Jesus, a todos os santos em Cristo

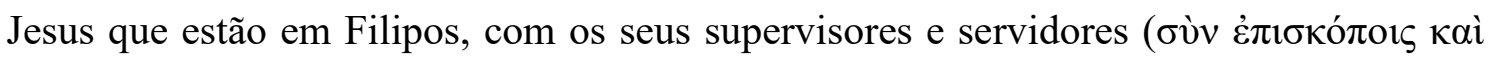

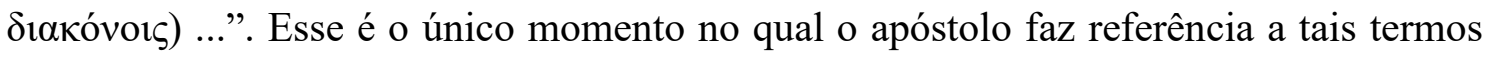
para referir-se a grupos determinados de direção da comunidade. Apesar de Koester querer ver aqui apenas títulos conferidos a missionários locais (KOESTER, 2012: 146), o que seria deveras incomum em toda a literatura cristã do primeiro século depois de Cristo, o mais provável é que devamos ver, aqui, um daqueles poucos trechos onde "Paulo dá destaque a um grupo distinto de ocupantes de cargos... no âmbito da comunidade talvez porque tenham sido responsáveis pelo presente enviado a ele" (BYRNE, 2011: 444).

Deste modo, podemos concluir que, à época de Paulo, a tendência existente nas comunidades por ele fundadas era a de marcar uma diferenciação hierárquica entre aquelas formas de serviço vinculadas à oralidade (o apóstolo prega, o profeta profetiza, o doutor ensina) e todas as outras que poderiam vir a servir ao propósito da igreja local, dentre elas à da governança do grupo e da assistência aos necessitados. O mais plausível é que tal fosse, mais ou menos, a ordem de coisas também nas igrejas fundadas pelo apóstolo, ou por seus colaboradores, na província da Ásia. No entanto, nota-se que Paulo faz um esforço considerável para realçar a importância daqueles que se dedicavam, "afadigando-se", ao serviço da comunidade, inserindo mais esta tarefa em seu cotidiano, a de administrar a igreja local. O apóstolo reforça sua importância, mesmo que por vezes não fosse esse o comportamento da comunidade local, como no caso de Corinto. Poderíamos mesmo teorizar, como o apoio da Didaché, que a sobreposição hierárquica dos apóstolos, profetas e doutores em relação ao resto da comunidade poderia advir da recepção de uma tal tradição por parte de Paulo, seja era originária de Antioquia da Síria, seja mesmo de Jerusalém ou de outro lugar da Palestina. O apóstolo encontrava-se na obrigação de aplicar o mesmo modelo nas comunidades por ele fundadas, dada a importância que conferia às tradições recebidas, que poderiam confirmar o seu trabalho e garantir que "não teria corrido em vão" (Gálatas 2,2). No entanto, com sua habilidade própria de adaptação a contextos diferenciados, provavelmente enxergou a utilidade em reforçar a importância do dom da governança e do serviço prestado por seus receptores, baseando-se em modelos como o da óikos (como visto no caso de Estéfanas, em Corinto) e das próprias associações de culto, que, em geral, possuíam uma hierarquia bem definida 
de administradores, e contando, inclusive e frequentemente, com "supervisores" e “servidores" (cf. KLOPPENBORG, 1996).

\subsection{2: Narrativas sobre o passado, considerações sobre o presente: Os Atos dos Apóstolos}

Os Atos dos Apóstolos trazem uma narrativa clara de quem possui a autoridade na comunidade e qual é a sua fonte. O Espírito Santo, enviado por Deus sucessivamente aos fieis convertidos (a começar por Pentecostes), confirma a missão especial dos apóstolos escolhidos por Jesus no primeiro volume da obra, o Evangelho de Lucas: “... recebereis uma força, a do Espírito Santo que descerá sobre vós, e sereis minhas testemunhas ( $\mu$ ov $\mu \alpha \alpha_{\rho} \tau v \rho \varepsilon \varsigma$ ) em Jerusalém, em toda a Judeia e Samaria, e até os confins da terra" (Atos 1,8). A partir de então, os apóstolos passam a exercer a missão de propagar a nova fé e de tomar decisões referentes à mesma, como no caso da assembleia reunida

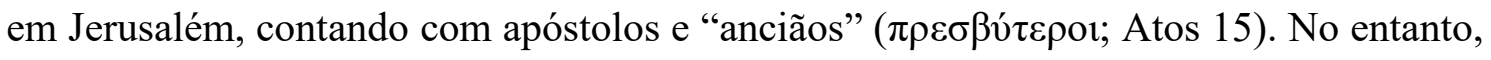
nunca a autoridade flui das próprias pessoas referidas: em todos os casos (inclusive na reunião citada), o ator principal é sempre o Espírito Santo, responsável, na visão do autor, pela guarda da jovem Igreja, quando começa a se propagar: "De fato, pareceu bem ao Espírito Santo e a nós..." $(15,28)$. Canais de ação do Espírito Santo são, também, os profetas: nos Atos, contudo, não são eles tão caracterizados por exortarem os cristãos reunidos, como parece ser o caso de 1Coríntios, mas por anunciarem acuradamente os eventos próximos que haverão de atingir a Igreja, por vezes estimulando a ação de seus membros $(11,28 ; 21,10-11)$. Tanto apóstolos como profetas são retratados sobretudo como itinerantes, embora os primeiros por vezes contem com uma localidade-base para a qual sempre podem retornar após a conclusão de sua atividade missionária: Jerusalém, no caso de Pedro $(8,25 ; 11,2)$, e Antioquia, para Paulo $(14,26 ; 18,22)$.

Como visto anteriormente, o objetivo principal da obra lucana (Lucas-Atos) é a confirmação narrativa do ensinamento recebido por um cristão genérico, neste caso representado pela figura obscura de Teófilo. Um dos ensinamentos que o autor espera ver solidificado em seus leitores é aquele referente à função dos líderes da comunidade, o qual expõe primordialmente por meio da boca do apóstolo Paulo, que tem um papel proeminente em sua narrativa ${ }^{117}$. A certa altura do relato, Paulo decide partir para

\footnotetext{
${ }^{117}$ Dos vinte e oito capítulos dos Atos dos Apóstolos, quinze (mais da metade) relatam exclusivamente o ministério de Paulo, sua prisão e transporte a Roma.
} 
Jerusalém, esperando chegar na cidade sagrada do judaísmo antes de Pentecostes (Atos 20,16). Em sua pressa, buscando não alongar sua viagem, passa ao largo de Éfeso, com cuja igreja tinha uma relação especial, considerando seus três anos de estadia na cidade (Atos 20,31). Não deixa, contudo, de chamar os “anciãos" ( $\pi \rho \varepsilon \sigma \beta \hat{\tau} \tau \varepsilon \rho o \imath)$ da comunidade efésia para ter com ele em Mileto, considerando ser essa a última vez que os verá (Atos 20,25). A eles, o apóstolo dirige um discurso que segue o gênero antigo dos discursos de despedida (FITZMYER, 2010: 674; TREBILCO, 2007: 176-177). Em certo momento do discurso, após fazer uma síntese de seu ministério, o Paulo lucano diz o seguinte aos anciãos que o escutam: "Estai atentos a vós mesmos e a todo o rebanho: nele o Espírito

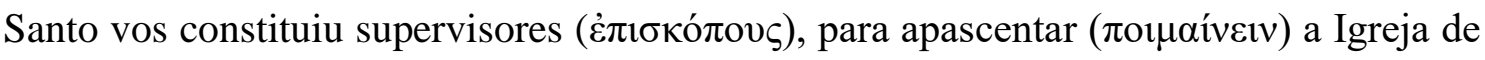
Deus, que ele adquiriu para si pelo sangue do seu próprio Filho" (Atos 20,28). Esse é um trecho dos Atos dos Apóstolos que interessa muito a essa pesquisa; por volta da década de 80 do séc. I, quando a obra é escrita, seu autor faz uma equivalência entre os anciãos cristãos de Éfeso e seus supervisores. Duas informações podem ser retiradas daqui: primeiramente, nos Atos não existe diferença alguma entre um ancião e um supervisor, ambos os termos se referem à mesma pessoa; em segundo lugar, não existe um único supervisor em Éfeso, mas sim um grupo delimitado e identificável, a ponto de serem designados a ir ver o apóstolo em Mileto.

Que características dos anciãos supervisores de Éfeso podemos retirar do texto dos Atos? Em primeiro lugar, observamos que, no relato, os líderes comunitários recebem sua missão diretamente de Paulo, como um mandato emanado pela autoridade apostólica (o autor o chama de "apóstolo" em Atos 14,14). Uma das características do antigo gênero discursivo de despedida é a designação, por parte daquele que está se despedindo, de sucessores para sua posição ou ofício (FITZMEYER, 1998: 674). Na verdade, nos Atos essa designação já é relatada anteriormente, ainda que não em Éfeso. No retorno de sua primeira viagem de pregação, Paulo e Barnabé passam pelas cidades nas quais haviam fundado igrejas, apontando anciãos para as mesmas e confiando-os "ao Senhor", após jejuarem e orarem (Atos 14,23). Desse modo, naquelas comunidades fundadas por ou relacionadas ao ministério de Paulo, os anciãos supervisores podem reclamar a origem de sua função no ministério de seu apóstolo fundador, ao menos segundo o autor ${ }^{118}$. O

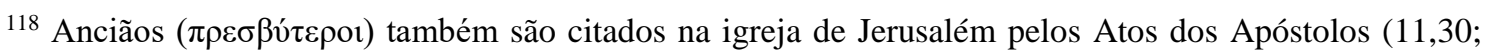
15,4.6.22-23; 21,28), inclusive em um momento de particular importância para a narrativa, ao se reunirem com os apóstolos para debater a necessidade de circuncisão aos gentios convertidos ao cristianismo. Contudo, ao contrário de sua contraparte nas comunidades fundadas por Paulo, os anciãos de Jerusalém não têm sua origem relatada. Considerando a existência de anciãos na administração da cidade de
} 
apóstolo, porém, aparece apenas como um instrumento de uma vontade maior; na verdade, o principal agente na constituição dos anciãos supervisores enquanto líderes de sua comunidade é o próprio Espírito Santo, como visto no trecho citado.

Em segundo lugar, a missão fundamental que recebem de Paulo é a de "apascentar a Igreja de Deus". O que significa essa sentença do autor? O trecho seguinte é importante para que a entendamos:

Bem sei que, depois de minha partida, introduzir-seão entre vós lobos vorazes ( $\lambda$ v́кol $\beta \alpha \rho \varepsilon i ٓ \varsigma)$ que não pouparão o rebanho. Mesmo do meio de vós surgirão alguns falando coisas pervertidas, para arrastarem atrás de si os discípulos. Vigiai ( $\gamma \rho \eta \gamma \rho \rho \varepsilon i \tau \tau)$, portanto, lembrados de que, durante três anos, dia e noite, não cessei de admoestar com lágrimas a cada um de vós. (Atos 20,29-31)

No trecho acima, a função dos anciãos supervisores faz-se um pouco mais clara. Eles devem "vigiar", como bons pastores, de modo a garantir que o evangelho seja guardado e transmitido em sua integridade dentro da comunidade. Seu trabalho, portanto, encontra-se fortemente vinculado à oralidade, a ponto de um desvio no mesmo causar efeitos claramente negativos à integridade da igreja. Em outras palavras, os pastores designados pelo apóstolo possuem como principal função o ensino e a exortação dentro da vivência comunal. Aparentemente, o autor estava enfrentando problemas com alguns anciãos supervisores de seu tempo (não se sabe ao certo se de Éfeso mesmo, embora o contexto da passagem pareça ser favorável a essa hipótese) que estariam espalhando o que ele considerava como "coisas pervertidas" $(\delta \imath \varepsilon \sigma \tau \rho \alpha \mu \mu \varepsilon ́ v \alpha)$. Torna-se compreensível, portanto, o destaque dado por ele a esse discurso, especialmente sua ocasião no texto, com Paulo dando adeus à comunidade que não veria mais.

Por outro lado, podemos também ter clareza do que o autor não espera que seja uma função própria dos anciãos supervisores: o cuidado com os bens materiais da igreja e com sua redistribuição aos mais necessitados. Em nenhum momento é feita qualquer menção a um encargo dos mesmos em administrar o fundo comum da comunidade ou se diz que o "apascentamento do rebanho" envolva alguma característica mais material. $\mathrm{Na}$

Jerusalém, muito provavelmente membros da aristocracia local (JEREMIAS, 2010: 304), é possível que o autor dos Atos tivesse aqui a imagem dos mesmos em mente, transpondo-a para a igreja, referindo-se a membros influentes que não eram apóstolos. 
verdade, considerando que uma das características dos discursos de despedidas é a utilização do próprio interlocutor como exemplo para seus ouvintes (FITZMYER, 2010: 674; TREBILCO, 2007: 176-177), poderia ser dito o contrário: o autor espera que os anciãos supervisores deleguem tal trabalho a outros. De fato, ao relatar o ministério dos doze primeiros apóstolos em Jerusalém, ele relata um conflito inicial entre os cristãos judeus de língua hebraica e os de língua grega, chamados de "helenistas"; segundo os últimos, os primeiros estariam sendo favorecidos no momento da redistribuição dos bens colocados em comum $(6,1)$. A resposta dos apóstolos é significativa: Não é conveniente que abandonemos a Palavra de Deus para servir as mesas. Procurai, antes, entre vós, irmãos, sete homens de boa reputação, repletos do Espírito e de sabedoria, e nós os encarregaremos desta tarefa. Quanto a nós, permaneceremos assíduos à oração e ao

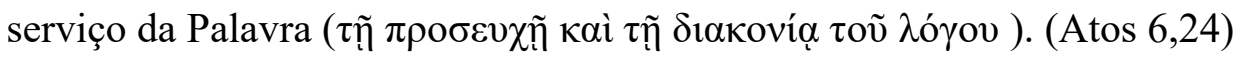

Desde então, o autor esforça-se por desvincular todos os apóstolos dessa função em seu relato, inclusive Paulo. É de particular importância a omissão que faz quanto ao motivo primordial da viagem final do apóstolo a Jerusalém, bem conhecido pelas suas cartas autênticas: levar uma coleta de dinheiro aos cristãos hierosolimitanos, que encontravam-se em necessidade (ver Romanos 15,25-26; 1 Coríntios 16,1-4; 2 Coríntios 9,1). O autor diz apenas que Paulo para lá ia "acorrentado pelo Espírito" (Atos 20,22). Quando o apresenta levando uma coleta do tipo à igreja de Jerusalém, é antes do início de sua atividade apostólica $(11,30)$. Considerando que, no discurso de despedida de Paulo, o autor visa usar o próprio serviço apostólico paulino como exemplo para os anciãos supervisores de seu tempo, claramente esses devem se afastar absolutamente do "servir às mesas" para se focar na manutenção da unidade comunal, por meio da admoestação e do "serviço da palavra".

Um último ponto no qual Paulo parece ser apresentado como exemplo pelo autor para os anciãos supervisores de seu tempo é no auto-sustento:

De resto, não cobicei prata, ouro, ou vestes de ninguém: vós mesmos sabeis que, às minhas precisões e às de meus companheiros, proveram estas

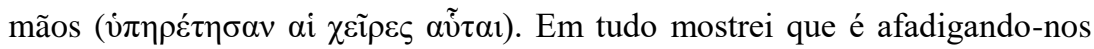
assim que devemos ajudar os fracos, tendo presentes as palavras do Senhor Jesus, que disse: Há mais felicidade em dar que em receber. (Atos 20,33-35) 
Os líderes da comunidade não devem esperar que seu ofício eclesial se torne uma profissão. Ao contrário, devem eles mesmos garantir seu sustento com o próprio trabalho, inclusive, provavelmente, ajudando à comunidade com o mesmo.

\subsection{3: (Im)pondo ordem no grupo: 1Timóteo}

A razão de nos voltarmos para esse documento consiste, principalmente, em dois fatores: em primeiro lugar, ele traz um testemunho antiquíssimo a respeito da função de supervisão; em segundo lugar, ele afirma estar relacionado a determinada situação específica da comunidade cristã de Éfeso, de importância óbvia para o presente estudo.

Tratemos do primeiro ponto. O propósito claro da carta, nas palavras de Robert A. Wild, é o de "exortar os líderes da igreja a valorizar e manter a ordem e estrutura eclesiástica e social" (WILD, 2011: 636). Deste modo, o autor anônimo apresenta, pela autoridade do apóstolo Paulo, uma série de instruções a respeito da organização comunal, tratando de temas como a oração a ser feita quando a comunidade estiver reunida $(2,1-8)$, o comportamento a ser esperado da parte das mulheres (2,9-15) e a exortação a ser feita aos cristãos em condição servil (6,1-2). Também de destaque é a instrução que faz a

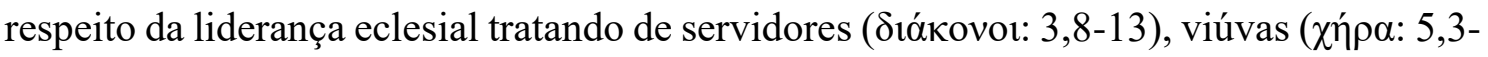

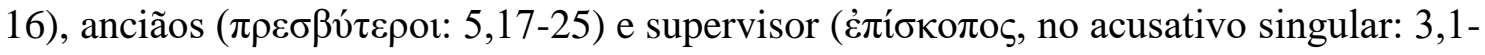
7). O trecho a respeito dessa última função vale ser citado por inteiro:

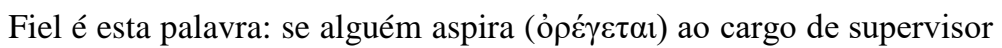

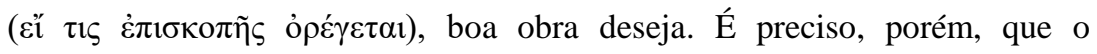
bispo/supervisor seja irrepreensível ( $\alpha v \varepsilon \pi i ́ \lambda \eta \mu \pi \tau o v)$, homem de uma única

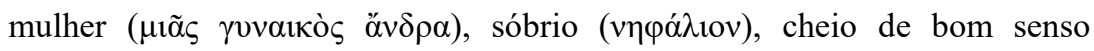

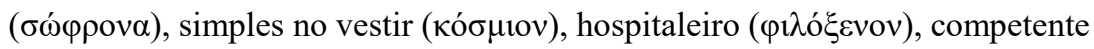
no ensino ( $\delta 1 \delta \alpha \kappa \tau \imath \kappa o ́ v)$, nem dado ao vinho ( $\pi \alpha ́ \rho o t v o v)$, nem briguento

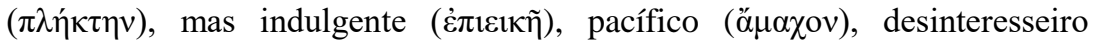

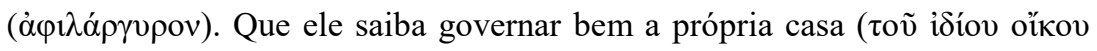

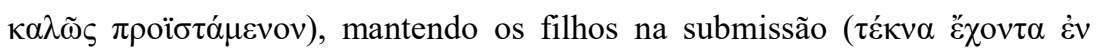

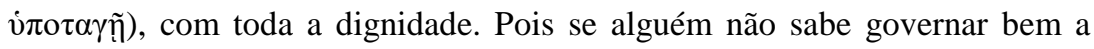
própria casa, como cuidará da Igreja de Deus? Que não seja recém-convertido

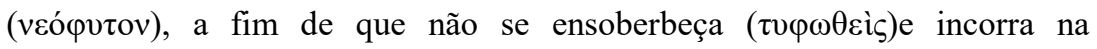
condenação que cabe ao diabo. Além disso, é preciso que os de fora ( $\tau \tilde{\omega} v$ $\check{\varepsilon} \xi \omega \theta \varepsilon v)$ lhe deem bom testemunho, para não cair no descrédito e nos laços do diabo. $(3,1-7)$ 
Apesar de o trecho ser pequeno, contém uma série de dados valiosos, ainda que possivelmente não esteja buscando tanto retratar uma realidade corrente quanto instruir. Não buscaremos, por enquanto, problematizar o texto, mas apenas retirar o máximo possível de informação que ele possa nos oferecer acerca da supervisão de comunidades cristãs em um período logo anterior ao das cartas de Inácio.

Um primeiro ponto é o de que o cargo deve ser aspirado por alguém, buscado. É de se notar que o autor se veja na necessidade de recomendar um ofício que, por sua posição, pode levar um cristão pouco instruído a ensoberbecer-se (JOHNSON, 2001: 213). Não há evidências suficientes, porém, que apontem para alguma espécie de eleição por parte da comunidade, mas podemos argumentar que era de se esperar alguma espécie de candidatura por parte de um interessado. Também é de se destacar a exortação de que o supervisor seja "o homem de uma mulher", o que pode significar muitas coisas: um homem fiel à sua esposa, não polígamo, que não houvesse se casado novamente no caso de uma viuvez ou mesmo uma preferência por um homem casado ao invés de um celibatário (Idem). Wild dá preferência ao primeiro sentido (WILD, 2011: 639), mas o último não deve ser ignorado. Espera-se do supervisor também que, além de "simples no vestir", seja "hospitaleiro", uma característica que será fundamental para a análise posterior. É fundamental também sublinhar a importância dada pelo autor à capacidade do candidato de governar bem sua oĩkos, para ser apto a fazer o mesmo com a "igreja de

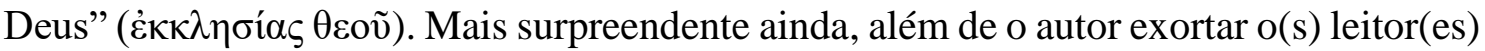
a fazer um exame minucioso do candidato de modo a avaliar se possui as qualidades elencadas, também instrui a buscar o "testemunho" ( $\mu \alpha \rho \tau$ cía) dos de fora. O autor não espera que os membros da comunidade se isolem do ambiente da pólis, mas instrui os mesmos a reservarem aos não-cristãos um papel importante em uma escolha fundamental para o grupo. Ainda assim, não devemos descartar a força do termo ह̌ $\xi \omega \theta \varepsilon v$, pelo qual o

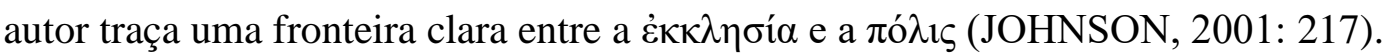

Existe um ponto, porém, que exige maior elucidação: existe uma diferença clara entre o ofício de supervisão e os anciãos, também citados na mesma carta? Esse problema surge de um trecho da chamada Carta a Tito, outra daquelas conhecidas como "Pastorais". Nela, o mesmo autor anônimo parece colocar anciãos e supervisores como termos sinônimos para a mesma função: "Eu te deixei em Creta para cuidardes da organização e ao mesmo tempo para que constituas anciãos em cada cidade (...) porque é preciso que, sendo ecônomo das coisas de Deus, o supervisor..." (1,6-7). Também é de se notar que, 
nessa mesma carta, o autor repete várias qualidades elencadas na Primeira Carta a Timóteo, como "homem de uma mulher", "hospitaleiro" e "irrepreensível". Esse fato,

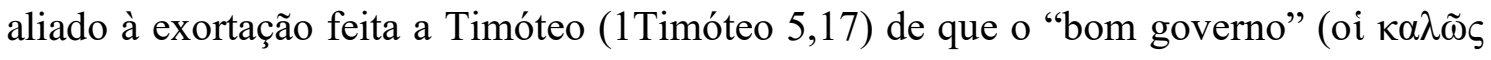

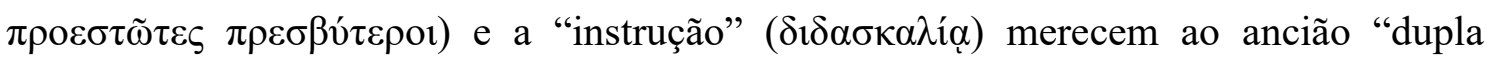

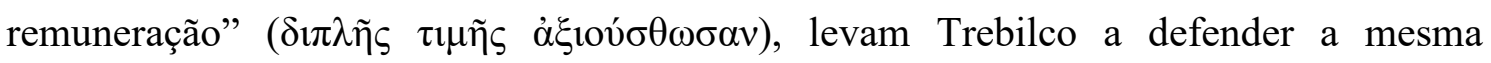
equivalência no caso da Primeira Carta a Timóteo (TREBILCO, 2004: 455). No entanto, o próprio Trebilco aceita que as duas cartas se dirigem a situações bem diferentes (TREBILCO, 2004: 209): enquanto 36 dos 113 versículos da 1Timóteo se dedicam à organização da liderança comunitária (31,8\%), apenas 5 de 46 versículos $(10,8 \%)$ da carta a Tito tratam do mesmo tema. Johnson nota bem, contra a visão tradicional da academia, que as Pastorais não são uma unidade, guardando diferenças claras entre si $^{119}$. Não há impedimento, portanto, para que haja uma organização da liderança comunitária diferente entre a 1Timóteo e a carta a Tito.

Nesse ponto, é de se notar que o autor anônimo fala do supervisor e dos anciãos em partes bem diferentes do texto (supervisor em 3,1-7; anciãos em 5,17-25). No trecho em que ele está tratando do supervisor, ele nunca usa o termo $\pi \rho \varepsilon \sigma \beta v ́ \tau \varepsilon \rho \varsigma_{\varsigma}$ para referirse ao mesmo, e o mesmo ocorre vice-versa. O fato de o autor esperar que os anciãos também governem e ensinem não pode ser usado como argumento decisivo, pois não podemos descartar a possibilidade de ofícios diferentes exercerem por vezes a mesma função, inclusive em conjunto. No entanto, é de se notar que em nenhum momento o autor espera que os anciãos sejam também hospitaleiros, como o faz com o supervisor em 1Timóteo 3,2 e em Tito 1,8. Por fim, é notório que, dentre todas as funções de liderança citadas pelo autor, o supervisor seja o único referido no singular. Adotamos, portanto, a conclusão de Johnson de que o "Pastor" representa, em sua carta, uma organização comunitária que conta com um supervisor exercendo a liderança como parte de um colégio de anciãos, o que o mesmo autor compara com outras formas de organização social do período. Esse era especialmente o caso em comunidades judaicas (Qumran e sinagogas ao redor do Mediterrâneo), que contavam, frequentemente, com um corpo

\footnotetext{
${ }^{119}$ Nota-se, por exemplo, a inexistência de referências a "servidores" em Tito, embora 1Timóteo discorra de forma destacada a respeito dos mesmos logo após tratar dos supervisores (1Timóteo 3,8-13). Outra diferença é a fonte de autoridade de Timóteo: enquanto 1Timóteo 4,14 afirma ter o mesmo recebido a imposição das mãos por parte de um "ancião", 2Timóteo 1,6 reserva tal honra ao próprio apóstolo Paulo. Do mesmo modo, ao referir-se a seus adversários doutrinários, o autor cita Himeneu e Alexandre em 1Timóteo 1,20; o mesmo Himeneu é citado em 2Timóteo 2,17, mas dessa vez em companhia de certo Fileto. Talvez o Alexandre referido na 1Timóteo seja o mesmo fundidor Alexandre citado em 2Timóteo 4,14, mas isso não é certo.
} 
colegiado de administração, encabeçado por um oficial específico; no caso de Qumran, o mebaqqer, e no das sinagogas, o ả $\rho \chi 1 \sigma v v \alpha ́ \gamma \omega \gamma o \varsigma$ (“arquisinagogo"), embora nesse caso o título aparentemente estivesse muito mais ligado à patronagem do que à administração da comunidade em si, sendo esta colocada sob os cuidados de uma $\gamma \varepsilon \rho o v \sigma i ́ \alpha$ ("conselho de anciãos"; JOHNSON, 2001: 218).

Ao início da carta fictícia estudada, o autor, escrevendo como Paulo, diz a Timóteo: "Se eu te recomendei permanecer em Éfeso, quando estava de viagem para a Macedônia, foi para admoestares..." $(1,2)$. Em tese, portanto, o autor espera que sua instrução seja seguida pela comunidade de Éfeso em específico. Alguns fatores apontam para a viabilidade desse pressuposto. Em primeiro lugar, como já visto, a 1Timóteo e a Tito, embora tratando de temas semelhantes, abordam os mesmos de maneira diferente. Enquanto a carta a Tito exorta à organização de uma liderança pouco complexa das comunidades de Creta, basicamente composta por anciãos supervisores (o que combina bem com o aparente quadro de comunidades fundadas há pouco tempo e que precisam que uma liderança seja instalada; cf. Tito 1,5), a 1Timóteo apresenta uma distribuição bem mais complexa da administração eclesial, não preocupada tanto em sua instalação quanto no controle do acesso à mesma. Em segundo lugar, outra carta composta pelo mesmo autor e dirigida também a Timóteo, relaciona claramente esse último a Éfeso, citando uma série de personagens que possuem algum laço documentado com a igreja da capital asiática (TREBILCO, 2004: 206): Tíquico (2Timóteo 4,12; Atos 20,4; 21,29), Erasto (2Timóteo 4,20; Atos 19,22), Trófimo (2Timóteo 4,20; Atos 20,4; 21,29), além dos mais conhecidos Prisca e Áquila (2Timóteo 4,19; Atos 18,18-19 e 24-26).

Desse modo, embora não haja provas contundentes a respeito, é muito provável que as duas cartas a Timóteo se dirijam à comunidade cristã de Éfeso e/ou reflitam a organização eclesial existente na mesma. Sendo esse o caso, a Primeira Carta a Timóteo testemunharia a existência de um cargo de supervisão que, embora compartilhando algumas funções com o corpo de anciãos, se destaca o suficiente para levar um ocupante recém-convertido a ensoberbecer-se, não apenas por sua posição dentro da comunidade, mas também por sua visibilidade pública, tendo-se em conta a importância que o autor dá para o testemunho "dos de fora" na escolha do supervisor da igreja. Por outro lado, o documento não tem por objetivo apontar a origem da autoridade do supervisor e dos anciãos. Afinal, o autor não visa estabelecer novas funções, nem fazer a apologia de sua existência. A carta foi escrita para regular a vida comunitária e, sobretudo, controlar o acesso de fieis a determinados ofícios de direção da igreja local, em um contexto visto 
como perigoso pelo autor, com membros da comunidade difundindo ensinamentos por ele considerados como errôneos. A necessidade de um supervisor patriarcal, com a experiência de administrador doméstico, deve ser incluída nessa conjuntura. Não se sabe, contudo, se aqueles considerados pelo Pastor como dissidentes, ou defensores do erro, estariam abertos ou não a uma tal autoridade. Talvez a restrição do acesso à supervisão visasse atingir tal grupo, mas não temos como ter certeza de como algo do tipo ocorreria.

Alguns outros pontos são de necessário destaque, para além das funções e autoridade do supervisor e dos anciãos da comunidade. O primeiro é a existência de

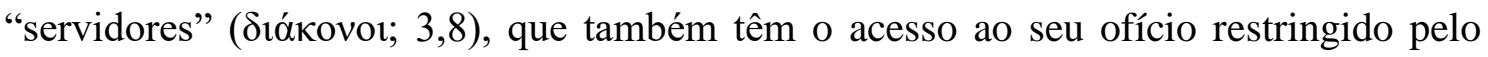
Pastor. Pelas qualidades exigidas, é de se imaginar que estivessem vinculados à governança da comunidade, talvez conectados, de alguma forma, ao próprio supervisor. O segundo é o rebaixamento explícito e consciente da participação feminina na liderança da igreja por parte do autor. Exigindo, por exemplo, que viúvas com menos de sessenta anos se casassem novamente $(5,9)$, o Pastor claramente espera diminuir o número de mulheres dedicadas ao serviço comum, inclusive, ao que parece, no ensino $(5,13)$. Trebilco enxerga em algumas declarações do autor sinais de que haveria viúvas envolvidas na difusão do ensinamento considerado errôneo, o que apenas confirmaria a existência de mulheres dedicadas ao ensino (TREBILCO, 2004: 507-528). Nesse caso, o Pastor veria no grupo por ele considerado dissidente algum elemento que deveria ser atrativo às mulheres da igreja, especialmente àquelas destacadas para o serviço, como as viúvas. A estratégia óbvia seria trabalhar para diminuir o papel das mulheres na liderança da igreja. Ainda assim, aparentemente ele não trabalha para evitar que mulheres entrem para o grupo dos servidores (ou "ministros", outra tradução possível).

Pesando o realce dado pela 1Timóteo de funções comunitárias destinadas a chefes de household exemplares, como o supervisor e os servidores, com o rebaixamento considerável do papel feminino pelo autor, acabamos por concordar com Dale B. Martin quando diz que, nesse documento, “a igreja se torna uma household, uma estrutura especificamente patriarcal na qual os homens mantêm funções e as mulheres não devem ter autoridade sobre eles" (B. MARTIN, 2012: 277). Neste caso, deve ser destacada a figura do supervisor, encarregado de cuidar da igreja como cuida de sua própria household, mantendo os filhos na submissão. Sobre este ponto, porém, uma análise mais específica é feita no capítulo 3. 


\subsection{4: A exortação do profeta: O Apocalipse de João}

Todos os documentos anteriormente citados abordam, de forma mais enfática ou não, a existência e função dos profetas nas comunidades cristãs mais antigas: os receptáculos do dom da profecia, que proferem as palavras do Espírito Santo perante a assembleia reunida, que são foco de uma abordagem por parte de Paulo em suas cartas; os itinerantes responsáveis por desvelar o futuro aos cristãos, quando Deus assim considera conveniente, conforme narrado pelos Atos dos Apóstolos; por fim, os cristãos que, com suas profecias, dão uma certa legitimação divina às indicações de homens aptos para a direção da comunidade, conforme sugerido por 1Timóteo. Todos esses documentos indicam que profetas encontravam-se atuantes nas primeiras igrejas fundadas na Ásia, durante todo o século I d.C., embora não possamos ter certeza de que fossem membros fixos de uma comunidade específica ou, seguindo a historiografia clássica, mais tendentes a uma itinerância. Vale, porém, notar que Atos e 1Timóteo não indicam em nenhum momento qualquer tensão entre a autoridade dos profetas e a dos administradores locais: em 1Timóteo, por exemplo, sua relação aparenta ser inclusive a de uma certa complementaridade; no momento em que recebe "o dom da graça" por meio da imposição das mãos dos anciãos, profecias são feitas sobre ele, podendo o texto chegar ao ponto de indicar que a sua escolha para exercer o serviço a ele confiado havia sido feita por meio de profecia (1Timóteo 4,14).

O Apocalipse de João, no entanto, diferencia-se de todos os documentos vistos anteriormente. De fato, ele é um dos poucos textos cristãos de que se tem notícia que foi escrito por um profeta. Ele é inestimável uma vez que, por trás de toda sua utilização de figuras do gênero apocalíptico judaico, existe uma imagem de como poderia ser caracterizada uma profecia cristã antiga e, também, que tipo de comportamento esperava o profeta de sua audiência com relação à proclamação profética e a si mesmo. Não que João utilize o gênero apocalíptico para se dedicar especialmente a qualquer defesa do ofício conferido a ele (em sua acepção) pelo Espírito Santo. No entanto, é possível notar, por meio de suas profecias, uma exigência de obediência ao conteúdo do que por ele é proclamado, uma vez que não é ele a fonte última da advertência profética, e sim o próprio Deus (TREBILCO, 2004: 496-502), que a teria concedido a Jesus Cristo, para que este a "mostrasse aos seus servos as coisas que devem acontecer muito em breve" $(1,1)$.

Se a proclamação profética garante ao "servo de Deus" a autoridade singular de

quem é veículo de comunicação entre Deus e suas igrejas na Ásia, de modo que as 
advertências e exortações saídas de sua boca (ou, no caso, de sua pena) devam ser entendidas por elas como sendo necessariamente de origem divina, nada é dito acerca daqueles incumbidos, conforme a documentação acima analisada, pela direção comunal, nem por meio de figuras simbólicas, nem por meio de críticas ou ameaças diretas ${ }^{120}$. Daí, poderíamos inferir duas possibilidades: ou o profeta os ignora por não lhes reconhecer autoridade alguma, ou tratar de suas funções ou da qualidade de seu trabalho não passa pelos seus objetivos, voltados mais para uma exortação das comunidades como um todo em um momento de crise, com perspectiva de perseguições cruentas. As duas leituras possuem peso, mas devemos notar que, aparentemente, não é do feitio do profeta calar acerca do que ele considera como desvio do ideal cristão. Os nicolaítas e os seguidores de "Jezabel" e "Balaão" sofrem severas reprimendas e ameaças de morte em nome de Deus (2,14-15.20-23). Embora não nos seja seguro fazer leituras a partir do silêncio, se mostraria difícil para nós ver no profeta João um opositor aos supervisores, anciãos e servidores das igrejas para as quais escreve, tendo em vista seu caráter fortemente combativo e agressivo. O mais provável para nós, portanto, seguindo Trebilco, é que a mensagem apocalíptica de João fosse dirigida inclusive aos diretores das comunidades para as quais escrevia, culpados das mesmas faltas, sujeitos às mesmas ameaças e dignos dos mesmos elogios, dirigidos ao seu grupo como um todo (Ibidem: 504-6).

\subsection{5: Observações finais sobre as lideranças na comunidade}

Diante do que foi retirado da documentação trabalhada neste capítulo, é necessário que façamos algumas observações finais acerca das formas de exercício da autoridade nas igrejas da Ásia Proconsular no primeiro século depois de Cristo, antes de partirmos para o próximo capítulo, onde abordaremos as próprias cartas de Inácio de Antioquia.

Antes de tudo, podemos observar, por meio da documentação, um processo social entre as comunidades cristãs asiáticas onde pode ser constatado um lento, porém progressivo, realce de lideranças internas voltadas, sobretudo, para a administração e condução fixa dos grupos. Os pólos são as cartas paulinas por um lado, onde existe uma considerável preponderância de funções vinculadas à oralidade (apóstolos que pregam,

\footnotetext{
${ }^{120}$ Alguns autores chegaram a enxergar no "anjo" responsável por cada igreja o "bispo" da mesma, que receberia as mensagens do Cristo como representante de sua comunidade. No entanto, Robert Joly vê bem o ideário tradicional judaico por trás desse anjo: "C'est un caractère bien connu des croyances apocalyptiques juives d'attribuer un ange directeur à des groups humains, depuis au moins le Prince du royaume de Perse, chez Daniel. Cette croyance apparaît de façon très particulière dans le christianisme d'Asie Mineure" (JOLY, 1979 : 76).
} 
profetas que revelam a vontade divina, doutores que ensinam), e as Cartas Pastorais por outro, onde o modelo da liderança está conectado à administração da household (óikos) e a autoridade apresenta um caráter marcadamente patriarcal. No primeiro caso, é possível pensarmos em uma autoridade em movimento: apóstolos, profetas e doutores não só não precisam permanecer fixos a uma localidade, como tendem, em geral, à itinerância; no segundo caso, a liderança é caracterizada como fixa, como o pai de família que está sempre presente para administrar sua casa. Os Atos dos Apóstolos se encaixam entre os dois documentos, realçando consideravelmente ambos os modelos de liderança. Historiadores como Ferdinand Christian Baur (BAUR, 1879: 16-61), no século XIX, Adolf von Harnack (HARNACK, 2004) na passagem de século, e Hans von Campenhausen (CAMPENHAUSEN, 1969), em meados do XX, enxergaram, neste caso, um processo de certa forma linear, onde, no período da atividade paulina, prevaleceria absolutamente formas espontâneas de liderança, com o critério sendo unicamente a inspiração de alguém pelo Espírito para o exercício de seu ministério da palavra, enquanto que, a partir do último terço do século I d.C., os ataques de grupos dissidentes obrigaria à organização de um corpo fixo de líderes vinculados permanentemente à comunidade local, advogando sua autoridade por outros meios que não necessariamente pela inspiração divina. No entanto, a partir do que foi analisado aqui, podemos questionar a linearidade desse modelo explicativo. Se existe uma mudança de realce ao longo do século, isso não significa que não existisse uma convivência entre as duas formas de liderança durante todo o primeiro século depois de Cristo. É esse o caso, como vimos, tanto nas cartas paulinas quanto nos Atos dos Apóstolos e nas Pastorais.

Por outro lado, quando as autoridades administrativas começam a se firmar e ganhar cada vez mais legitimidade (a qual, como 1Coríntios exemplifica, poderia não estar tão garantida aos olhos dos fieis), sobretudo na ausência de autoridades maiores como Paulo e seus associados, é notório que existe uma preocupação em prover as mesmas de uma forma adaptável ao ambiente urbano mediterrânico. Já em Filipenses existe uma rara menção da parte do apóstolo a "supervisores" e "servidores"; embora não possamos afirmar certamente que tais nomenclaturas já estivessem em uso no mesmo período também na Ásia Proconsular, torna-se patente, na região, a solidificação de funções designadas desta forma por volta do fim do século I d.C., como visto através de 1Timóteo. Edwin Hatch foi o pioneiro em ver tal uso como sendo retirado das formas de designação de administradores e funcionários de associações voluntárias, sobretudo aquelas voltadas para o culto de uma divindade específica ou para a garantia de 
sepultamento digno para seus membros (HATCH, 1882). Daí Hatch tirou a conclusão de que as igrejas mais antigas poderiam também ser consideradas como associações do mesmo tipo. Não precisamos ir tão longe, sendo melhor permanecer com o julgamento de Meeks de que, embora existam elementos de tais associações nas igrejas paulinas, eles não são suficientes para caracterizá-las como tal. No entanto, a teoria de Hatch a respeito das nomenclaturas reservadas às autoridades comunitárias cristãs vem sendo cada vez mais confirmada por inúmeras inscrições que vão sendo descobertas, conforme apresentado por Alistair C. Stewart (STEWART, 2014: 55-119). Aqui, também pode ser argumentada uma influência da parte da sinagoga, com seu colégio de anciãos à frente da comunidade judaica presente em uma determinada pólis. Um dos maiores argumentadores recentes pela forte influência da sinagoga sobre as igrejas primitivas em termos de organização comunal é James Tunstead Burtchaell (BURTCHAELL, 1992: 180-200), mas a teoria pode ser traçada até, pelo menos, Ferdinand Christian Baur (BAUR, 1882: 1-61), que considerava a formação de uma hierarquia eclesiástica o resultado dos conflitos de uma corrente judeu-cristã (encabeçada pela igreja de Roma) com seus adversários gnósticos e montanistas.

Mais recente ainda é a análise de Alistair C. Stewart, um grande admirador da obra de Edwin Hatch. Ele desenvolve a teoria do último ao enxergar na igreja cristã presente em uma cidade uma "federação" de igrejas diversas, consideravelmente autônomas entre si e baseadas em ambientes domésticos (STEWART, 2014: 11-53). Em sua visão, cada uma dessas casas-igrejas seria liderada por um "supervisor", auxiliado, de sua parte, por "servidores"; ao mesmo tempo, esse supervisor seria considerado um ancião, por fazer parte do colegiado responsável pela administração coletiva de todo o conjunto de igrejas presentes em uma mesma cidade. Apesar de a teoria de Stewart ser interessante, sua principal falha é a falta de documentação que sustente um modelo tão delineado (e também generalizado, diga-se de passagem) de organização das igrejas cristãs mais antigas. No entanto, sua obra serve para nos recordar que as casas-igrejas muito provavelmente contavam com considerável autonomia, e que a mesma poderia se manifestar pela diversidade de visões acerca de autoridade, culto e doutrina. A identidade mais local poderia francamente, por vezes, se sobrepor à mais geral. 


\section{Capítulo 3: Inácio de Antioquia e o supervisor único da comunidade cristã}

Nas primeiras duas décadas do século II d.C., as comunidades cristãs da província romana da Ásia Proconsular pouco deveriam diferir daquela cuja imagem, ainda que severamente embaçada pelo caráter diminuto da documentação a respeito, foi traçada no capítulo 2. Cada vez mais adotando características que a fariam (em tese) ser reconhecida pelos não-membros como um dos muitos grupos religiosos de culto privativo, presentes no ambiente urbano mediterrânico, seus líderes vão tomando traços funcionais familiares

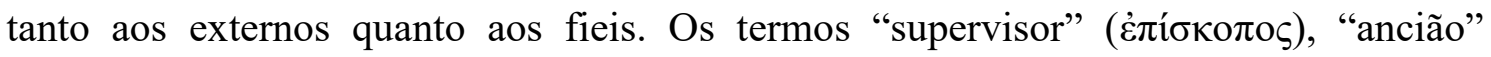

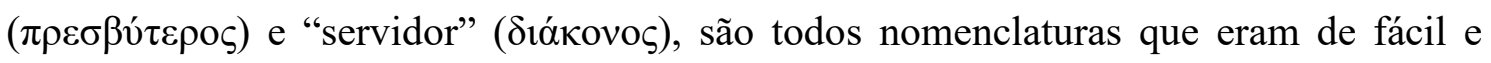
direta aceitação por qualquer habitante da cidade mediterrânica de língua grega. Do mesmo modo, a casa (oĩkoৎ) como ambiente e base para as comunidades mais locais também não era um elemento estranho à sociedade urbana no geral; abrir as portas do ambiente doméstico para a reunião de um grupo religioso ou filosófico era mesmo uma maneira conhecida de exercer o patronato.

Nesse mesmo ambiente, a ceia sagrada servia como um momento de identificação comum do grupo, uma vez que, aparentemente, apenas os iniciados poderiam dela participar plenamente, ainda que algumas passagens das cartas de Paulo sugiram uma relativa abertura para não-membros. É significativo, porém, que documentos que refletem a importância da ceia ritual cristã não se dediquem a explanar acerca de uma presidência da mesma por um indivíduo ou grupo específico. Podemos inferir que, talvez, esse não fosse um problema premente, nem para Paulo, nem para os autores de Atos dos Apóstolos e 1Timóteo. Se, seguindo Alistair C. Stewart, aceitarmos que o mais comum seria que o próprio chefe da casa fosse o responsável tanto pelo provimento quanto pela presidência da mesa, é de impressionar que, por exemplo, 1Timóteo não faça nenhuma referência a esse fato quanto se refere à necessidade de o supervisor ser um bom "administrador da casa" e também "hospitaleiro", uma vez que, na visão do autor, era esse mesmo membro da comunidade o responsável principal por acolher as reuniões em sua própria casa. $\mathrm{Na}$ realidade, não podemos inferir nada com certeza e nem argumentar a partir do silêncio, mas podemos lembrar do realce dado a profetas no ritual por 1Coríntios e pela Didaché. Talvez a liderança por parte de um chefe doméstico não fosse tão automática. De qualquer forma, o mais importante aqui é que os documentos cristãos do primeiro século depois de Cristo, em geral, silenciam acerca de quem dirigia a mesa sagrada cristã na Ásia, se alguém o fazia especialmente. 
É mais ou menos esse o quadro das igrejas asiáticas quando, em meados da década de 10 do século II d.C., um homem chamado Inácio de Antioquia passa pela região, escoltado como prisioneiro rumando a Roma. Ao mesmo tempo, porém, não era um cenário de completa unidade entre os agrupamentos cristãos locais. Como vimos anteriormente, no capítulo 2, na medida em que o ambiente doméstico servia como centro de reunião de grupos cristãos específicos (embora não saibamos exatamente quais critérios poderiam ser utilizados, inicialmente, para a demarcação dos grupos que frequentariam cada casa), a incapacidade espacial comum em acolher todos os fieis de uma mesma cidade tendia a dar abertura a organização de comunidades menores, reunidas em casas diferentes em um mesmo centro urbano. Aqui temos um contexto propício à manifestação da diversidade comum ao primeiro século do cristianismo, o que é perfeitamente visível por meio da documentação da época, mesmo aquela reunida, uma ao lado da outra, no cânon tradicional do Novo Testamento.

Por muito tempo, durante boa parte do século XIX e início do XX, a historiografia nutriu a imagem de um cristianismo que se desenvolve consideravelmente em termos doutrinais, rituais e organizacionais, antes de ser atacado severamente por dissidências internas, fruto de uma tendência em geral identificada como iniciando sobretudo a partir do fim do século I d.C., com a formulação de doutrinas contrastantes com aquelas aceitas pelos primeiros grupos cristãos. O trabalho de Walter Bauer, Rechtgläubigkeit und Ketzerei im ältesten Christentum (traduzido para o inglês e o francês como "Ortodoxia e Heresia no Cristianismo mais Antigo), teve o mérito de colocar tal visão em xeque e apresentar um quadro social para o cristianismo mais antigo onde a diversidade sempre foi um fator essencial (BAUER, 2009: 255-265). Para tanto, não é preciso esperar pelo advento do gnosticismo, o grande adversário da ortodoxia nascente no século II d.C.; para tomarmos um exemplo, o princípio da já citada "Carta de Tiago" de que apenas a fé não basta para alguém se salvar, simplesmente não se coaduna com a afirmação de Paulo de que a fé em Cristo é o suficiente para tanto, a não ser pelo exercício teológico mais mirabolante. Na visão de um historiador, porém, ambos os documentos já servem de atestação para uma diversidade de visões acerca de um mesmo tema, ainda em pleno século I d.C. Ao mesmo tempo, se encararmos os evangelhos canônicos sem quaisquer conceitos anteriores, veremos uma diferença gritante entre a representação de Jesus em Marcos, que hesita muito em conferir-lhe um título claro de divindade, e João, que lança fora qualquer receio a respeito em seus primeiros versos, inclusive possivelmente 
apontando o dedo contra os hesitantes representados pelo primeiro evangelho, se aceitarmos a análise de Raymond E. Brown (BROWN, 2011: 88-9).

A diversidade, portanto, é uma característica essencial das primeiras comunidades cristãs, o que não significa que fosse exatamente aceita. É largamente considerada, entre os estudiosos, a possibilidade de a Carta de Tiago visar fazer uma crítica explícita aos que adotavam a tese de Paulo, assim como este último não aceitaria que alguém divulgasse uma "boa-nova" diferente da sua (e nós sabemos que havia muitas pessoas dispostas a tanto). Já vimos, no capítulo 2, como essa era uma preocupação também do autor dos Atos dos Apóstolos, expressada pelo discurso feito por Paulo aos anciãos da igreja de Éfeso. 1Timóteo também se foca muito na necessidade de combater a difusão de ensinamentos considerados errôneos pelo autor (cf. 1Timóteo 1,3-7; 4,1-16; 6,2-10); daí, provavelmente, deriva a necessidade de um candidato a supervisor ter a capacidade de governar bem a "casa de Deus", assim como consegue fazer seus filhos lhe serem submissos. Em outras palavras, por volta do último terço do século I d.C., faz-se cada vez mais presente uma tendência ao controle e repressão da diversidade no seio das comunidades cristãs da Ásia. Os cristãos simplesmente não poderiam dizer tudo o que quisessem, especialmente quando em posições de influência. A unidade de crença e prática era necessária, e esse é o ponto central para a narrativa deste terceiro capítulo da dissertação: afinal, como Inácio concebe ser o supervisor o meio pelo qual a diversidade condenável possa dar lugar à unidade? Quais são as práticas sociais advogadas pelo autor para que tal objetivo seja alcançado? Quais outras práticas sociais devem ser condenadas?

Como, no capítulo 3, o foco volta-se plenamente para Inácio de Antioquia e suas cartas, antes de partirmos para uma análise própria das mesmas, algumas perguntas precisam ser respondidas: que cartas são essas e como elas chegaram até nós? O que elas podem nos dizer a respeito de seu autor, se é que elas podem nos comunicar qualquer sobre sua vida? Para tais questões estão reservadas, respectivamente, as seções 1 e 2. Após ambas serem respondidas, o ponto central da terceira seção é a forma como Inácio representa a si mesmo por meio de suas cartas, como advogado que é de uma determinada tese a respeito da unidade que considera necessária à comunidade cristã urbana. Por fim, a seção 4 faz a análise das próprias ideias inacianas, como elas dialogam com as situações locais às quais o autor faz referência e quais os impactos sociais que têm (ou visam ter) sobre as formas de convivência entre os cristãos da Ásia. 


\section{1: As cartas de Inácio de Antioquia}

Em determinado momento de sua viagem como prisioneiro rumo à morte (ao

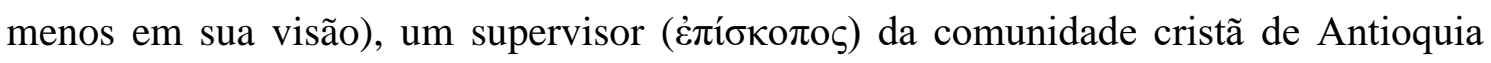
chamado Inácio decide-se, por ideia própria ou vinda de outrem, a escrever algumas cartas tanto para destinatários coletivos quanto para individuais. A facilidade com que discorre sobre diferentes assuntos e a forma persuasiva com que constrói seus argumentos e os distribui pelo documento podem ser indicativos de que não era amador na prática epistolar: poderia ter escrito muitas cartas durante seu ministério, envolvendo-se em querelas que nos são hoje quase completamente desconhecidas por conta do vácuo documental que predomina sobre o cristianismo do último terço do século I d.C. ${ }^{121}$. Justamente essa escassez documental é a razão de as cartas inacianas serem tão valorizadas hoje pelos estudiosos de cristianismo antigo, pelo menos por aqueles que, seguindo a opinião majoritária na academia, aceitam a autoria por Inácio de pelo menos sete cartas: aos cristãos de Éfeso, aos de Magnésia, aos de Trália, aos de Roma, aos de Filadélfia, aos de Esmirna e a Policarpo, lendário bispo esmirniota ${ }^{122}$.

No entanto, como é comum na área de História Antiga, não possuímos as cartas autógrafas, ou seja, as peças originais escritas à mão, possivelmente por Burro, diácono efésio que Inácio teria pedido que permanecesse junto a ele para prestar serviços em sua viagem como prisioneiro (cf. In.Efésios 2,1; In.Romanos 10,1; In.Filadelfienses 11,2; In.Esmirniotas 12,1). As sete cartas inacianas são exemplos de documentos antigos dos quais as peças mais antigas são manuscritos medievais, conservados tanto no idioma original grego quanto em uma série de traduções, destacando-se entre elas a latina. Portanto, é necessário fazer-se a pergunta: como ter a garantia de que essas sete cartas são autênticas? De fato, outras além delas foram escritas, afirmando terem Inácio por autor. Por que essas são universalmente rejeitadas como composições inacianas? Como se deu o processo de transmissão dessas cartas e qual foi o trabalho crítico que veio a separar as autênticas das forjadas?

\footnotetext{
${ }^{121}$ Koester nota bem o fato de não conhecermos, por meio de documentação direta, praticamente nada sobre qualquer personagem desse período além de meros nomes, como no caso de João de Patmos (KOESTER, 2005: 298). É possível, porém, que as chamadas "Cartas Pastorais" reflitam de alguma forma a ação de seguidores próximos do apóstolo Paulo, Timóteo e Tito, nas igrejas de Éfeso e de Creta (FREND, 1985: 127).

${ }^{122}$ Policarpo de Esmirna haveria de se tornar mártir de sua igreja, inspirando a composição de uma das primeiras peças de inspiração hagiográfica, o Martírio de Policarpo, escrito coletivamente em forma de carta pela comunidade de Esmirna àquela presente em Filomélio na Frígia.
} 
Como já referido diversas vezes, os documentos que temos de autoria direta de Inácio de Antioquia são cartas. Todas as obras que afirmam tê-lo como idealizador e compositor pertencem ao gênero epistolográfico (SCHOEDEL, 1985: 7; JEFFORD, 2012: 46). São, portanto, organizadas antes de tudo como comunicação escrita entre um remetente e seu(s) destinatário(s) (ROSENMEYER, 2001: 20). Conforme Rosenmeyer, a carta já era vista à época de Inácio como uma espécie de substituição a uma conversa que, devido a limitações geográficas, não poderia ser concretizada presencialmente pelas duas partes envolvidas na comunicação (ROSENMEYER, 2001: 20). Esse pressuposto encontrava-se por trás de cartas tanto verídicas quanto fictícias ou falsificadas: era importante que, tanto em um caso quanto em outro, a carta se apresentasse como registro de uma comunicação que, não podendo ser realizada plenamente na conversação direta, era feita com papiro e tinta. Dependendo do grau de destaque do autor da mesma e/ou de seu objeto, a carta poderia ser guardada de forma especial, assim como copiada, de modo a ser difundida entre os admiradores daquela mesma pessoa. Foi esse o caso com as cartas de Suetônio, Paulo, Plínio e, claro, Inácio. Em suma, as cartas constituíam um gênero literário próprio:

As cartas faziam parte, assim como a Historiografia, de um gênero literário. Tinham, portanto, certas características genéricas: uma saudação inicial, o desenvolvimento do tema e da mensagem, uma conclusão, como uma firma do autor. (VASCONCELLOS e FUNARI, 2013: 22)

No caso da figura histórica central para nosso estudo, encontram-se presentes em manuscritos medievais as seguintes cartas que reclamam sua autoria:

. Uma carta aos cristãos de Éfeso;

. Uma carta aos cristãos de Magnésia;

. Uma carta aos cristãos de Trália;

. Uma carta aos cristãos de Roma;

. Uma carta aos cristãos de Filadélfia;

. Uma carta aos cristãos de Esmirna;

. Uma carta a Policarpo de Esmirna;

. Uma carta aos cristãos de Tarso;

. Uma carta aos cristãos de Antioquia;

. Uma carta a Hero de Antioquia; 
. Uma carta aos cristãos de Filipos;

. Uma carta a Maria de Cassobola

Podem ser contabilizadas, portanto, doze cartas inacianas na longa tradição manuscrita, sem contar outras cartas disponíveis unicamente em latim e que se encontram vinculadas a tradições lendárias acerca do bispo de Antioquia, como no caso de uma comunicação sua com Maria, mãe de Jesus, conhecida de Jacopo de Varazze, que a cita em Legenda aurea 36. É necessário, porém, verificar, antes de analisar o desenvolvimento do monepiscopado nas cartas de Inácio de Antioquia, se todas estas cartas anteriormente referidas possuem alguma base para serem consideradas autênticas, ou seja, compostas a partir de uma ação direta e deliberada do próprio autor pretendido.

\subsection{1: Policarpo de Esmirna sobre as cartas inacianas}

A história da transmissão das cartas de Inácio é um tanto quanto complexa, com algumas referências externas ao seu início e com a inserção de cartas forjadas no meio. No entanto, ela nos indica que os textos inacianos foram consideravelmente valorizados desde sua composição (JEFFORD, 2012: 45). O primeiro testemunho que temos de um trabalho de cópia dos ditos documentos encontra-se em um breve bilhete escrito pelo bispo de Esmirna, chamado Policarpo, aos cristãos da igreja de Filipos, fundada pelo apóstolo Paulo mais ou menos na metade do século I (cf. Atos 16,11-15; Filipenses 1,311), e que se encontra integrado, a uma carta maior escrita à mesma comunidade em uma data posterior, sendo a ela fundido em algum momento desconhecido de seu processo de transmissão ${ }^{123}$. Nele, diz Policarpo: “As epístolas de Inácio enviadas a nós por ele e outras

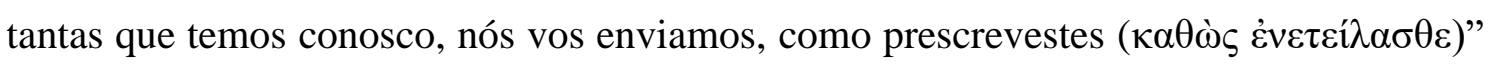
(Filipenses 13,2). Deste trecho, duas informações podem ser retiradas: primeiro, já existe,

\footnotetext{
${ }^{123}$ A razão da separação do cap. 13 da Carta aos Filipenses do resto do corpo textual é a visível contradição entre o trecho citado, que pretende estar Inácio ainda vivo, e o cap. 9, no qual é dito: “... que vós também observastes com vossos próprios olhos não somente nos afortunadíssimos Inácio, Zózimo e Rufo... Convencei-vos de que nenhum deles agiu em vão, mas na fé e na justiça, e que eles estão no lugar que mereceram, com o Senhor, com o qual também sofreram" (9,1-2). A maior parte dos acadêmicos, portanto, defende a escrita anterior, da parte de Policarpo, do cap. 13, um bilhete informando a intenção do bispo de enviar a carta dos cristãos filipenses aos antioquenos e pedindo informações de Inácio e dos que o acompanham, e o resto do texto, que constituiria uma carta escrita cerca de vinte anos depois como resposta a um pedido dos mesmos filipenses, tendo por tema principal a irrupção de doutrinas consideradas heterodoxas e o escândalo financeiro protagonizado pelo presbítero Valente (EHRMAN, 2003: 326-9; JEFFORD, 2012: 74-6)). Todo o processo de transmissão do texto da Carta aos Filipenses é muito fragmentado (KOESTER, 2005: 326), com a existência de um único texto completo em latim e versões incompletas em grego (JEFFORD, 2012: 74), incluindo a preservação de uma cópia dos capítulos 9 e 13 por Eusébio em sua História Eclesiástica (3.36.13-15).
} 
no momento em que o bilhete é escrito, um processo de cópia e transmissão das cartas de Inácio, aos menos em Esmirna; segundo, o envio das cópias das cartas de Inácio se dá não por iniciativa de Policarpo, mas por "prescrição" dos próprios cristãos filipenses em carta enviada anteriormente (e perdida). É importante notar que, no momento em que é escrito o bilhete citado, Inácio ainda poderia estar vivo, o que parece indicar Policarpo ao pedir notícias dele e "dos que estão com ele" (no presente; Pol.Filipenses 13,2). A conclusão que tiramos a partir do trecho citado é que, seja ainda antes da morte de Inácio ou logo depois da mesma, já existe grande demanda pela leitura e conservação de suas cartas nas igrejas de Filipos e Esmirna, talvez em outras também.

A passagem de Inácio por Esmirna, na Ásia, e por Filipos, na Macedônia, parece ter marcado bastante a memória das comunidades cristãs de ambas as cidades, e é possível que a conservação e difusão dos escritos do antioqueno tenham tido uma parte nisso, ou que sejam resultado desse evento. Em carta posterior mais extensa, Policarpo exorta seus destinatários filipenses a seguirem os exemplos de mártires que lhes eram bem conhecidos, estando Inácio entre eles:

Desse modo, urjo-vos todos a obedecer a palavra de justiça e praticar toda perseverança, que também observastes com vossos olhos não somente nos bem-aventurados Inácio, Zósimo e Rufo, mas também em outros dos vossos, e no próprio Paulo e outros apóstolos; convencidos de que todos eles não correram em vão, mas na fé e na justiça, e que estão no lugar que lhes é devido, ao lado do Senhor, com o qual também sofreram. (Pol.Filipenses 9,1-2)

A partir do trecho citado, é possível se fazer duas observações. Em primeiro lugar, Policarpo não está preocupado em apresentar Inácio (assim como Zósimo e Rufo, que, para além dos nomes, nos são inteiramente desconhecidos ${ }^{124}$ ) aos seus destinatários. Ao

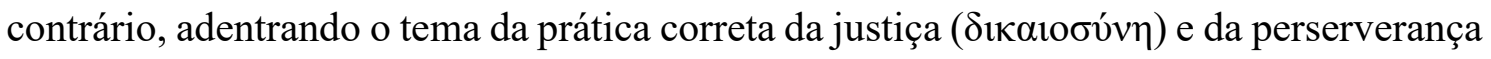
( cristãos filipenses. Policarpo chama-os para pensar além, e lembrar não apenas de Inácio, Zósimo e Rufo, mas também de seu fundador, Paulo, cujo sofrimento lhes era bem

${ }^{124}$ É possível que Zósimo e Rufo fossem companheiros de prisão de Inácio, mesmo que este não faça nenhuma referência a quaisquer outros prisioneiros (cristãos ou não) sendo escoltados juntamente com ele a Roma. De fato, no já citado bilhete enviado por Policarpo aos cristãos filipenses, o bispo de Esmirna pede notícias de Inácio e dos "que estão com ele" (Pol.Filipenses 13,2). O mais provável, porém, é que Policarpo esteja se referindo aqui a Burro, diácono efésio que Inácio havia pedido que permanecesse com ele (cf. In.Efésios 2,1; In.Esmirniotas 12,1), a Filo, diácono da Cilícia, e a Reo Agátopo (In.Filadelfienses 11,1). 
conhecido por meio de sua carta conservada no cânon do Novo Testamento ${ }^{125}$. Desse modo, é possível que Inácio se mantenha como uma figura cuja memória é guardada com zelo em Filipos e, provavelmente, em Esmirna também, considerando que quem escreve é o bispo desta última. Em segundo lugar, é necessário se notar que, apesar do processo de cópia referido no bilhete analisado acima, Policarpo reforça a lembrança dos filipenses do Inácio mártir e não do Inácio escritor. O exemplo de Inácio foi visto pelos seus destinatários e isso basta para que estes o guardem como ideal a ser seguido. As cartas do antioqueno não são referidas e nem citadas em nenhum momento.

\subsection{2: Eusébio de Cesareia sobre as cartas inacianas}

No entanto, a grande testemunha antiga acerca de Inácio de Antioquia (e também a mais relevante para a consideração da transmissão de suas cartas), é, como usual para as fontes cristãs dos primeiros séculos, Eusébio de Cesareia, um seguidor e admirador de Orígenes que, por meio de sua obra literária e política, haveria de ter um peso determinante na passagem da Igreja de sociedade legalmente proscrita para organização religiosa altamente favorecida pelo imperador. Seu grande legado para a historiografia clássica, assim como para os estudiosos da Igreja antiga, é sua obra monumental História Eclesiástica, organizada em dez livros. Sobre Inácio, Eusébio dedica uma fatia considerável do terceiro livro, primeiramente em um breve trecho traçando a sucessão episcopal na igreja de Antioquia: "Evódio foi o primeiro bispo estabelecido em Antioquia; depois ilustrou-se o segundo, Inácio, nessa mesma ocasião" (III.22). Neste trecho, Eusébio insere Inácio na narrativa na categoria que é central em sua obra, a saber, a sucessão dos apóstolos nos bispos presidindo as diversas igrejas, especialmente aquelas de Roma, Alexandria, Antioquia e Jerusalém ${ }^{126}$. Desse modo, o autor retoma a tradição já encontrada em Orígenes de que Inácio seria parte de uma sucessão de bispos que se desenvolveria a partir da fundação da igreja de Antioquia e de sua regência pelo apóstolo

\footnotetext{
${ }^{125}$ Paulo encontrava-se preso quando da escrita de Filipenses (cf. Filipenses 1,12), ou ao menos de uma das cartas que compõem o documento que conhecemos hoje. A perseverança exemplar de Paulo referida por Policarpo provavelmente é aquela expressa em Filipenses 1,20-21: "Minha expectativa e esperança é de que em nada serei confundido, mas com toda a ousadia, agora como sempre, Cristo será engrandecido em meu corpo, pela vida ou pela morte. Pois para mim o viver é Cristo e o morrer é lucro". Muitos autores têm defendido que a carta canônica de Paulo aos filipenses seria, na verdade, a junção de duas ou três cartas em uma só (cf. BROWN, 1997: 496-8; BYRNE, 2011: 442; KOESTER, 2005: 145-8). Essa hipótese encontra um apoio considerável em um trecho da carta de Policarpo aos mesmos cristãos: "E quando ele [Paulo] estava ausente, vos escreveu cartas" (Pol.Filipenses 3,2).

${ }^{126}$ De fato, as primeiras palavras de sua obra são: "Traçar as sucessões dos sagrados apóstolos..." (História Eclesiástica I.1,1).
} 
Pedro. A inserção do antioqueno na sucessão apostólica da igreja síria é o ensejo para Eusébio compor uma narrativa específica a seu respeito, que toma uma parte considerável de seu terceiro livro:

Naquele tempo distinguiu-se na Ásia um discípulo dos apóstolos, Policarpo, que fora estabelecido bispo da Igreja de Esmirna por testemunhas e servos. Simultaneamente eram de igual modo conhecidos Papias, bispo também ele, da Igreja de Hierápolis, e Inácio, até hoje afamado, e que obtivera, como segundo sucessor de Pedro, o episcopado em Antioquia. (III.36.1-2)

Inácio é colocado ao lado de Policarpo de Esmirna e Papias de Hierápolis como homens famosos do período a seguir da morte do último apóstolo, João, que teria alcançado o período de Trajano (III.23.3-4). Tanto Policarpo quanto Inácio são

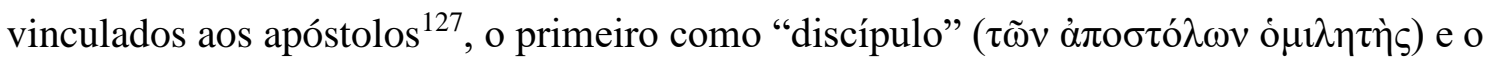

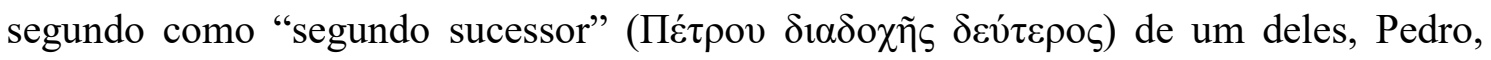
seguindo a mesma tradição já tratada acima. É interessante o destaque dado por Eusébio a Inácio ao afirmar ser este "até hoje afamado" ( clara da permanência da figura do bispo mártir antioqueno na memória coletiva das igrejas, não só da Síria, da Ásia e de Roma (com as quais havia se relacionado diretamente), mas também em comunidades tão distantes quanto às da Palestina (de onde Eusébio escreve), às do Egito (de onde Orígenes provém) e às da Gália (onde Irineu atua, embora deva-se recordar sua origem asiata e uma passagem por Roma). Não se pode desprezar a possibilidade de a transmissão de seus escritos ter acompanhado tal fama, especialmente pela tripla qualificação de sua autoria: Inácio é mártir, bispo e sucessor próximo de ninguém menos que o apóstolo Pedro em Antioquia.

No momento, porém, as mais importantes informações a nós concedidas por Eusébio a respeito de Inácio de Antioquia são aquelas referentes a suas cartas. Antes de tudo, o autor apresenta as circunstâncias nas quais as cartas foram escritas: o bispo de Antioquia teria sido preso e enviado a Roma para ser devorado pelas feras "por causa do

\footnotetext{
${ }^{127}$ Nenhuma ligação explícita é feita entre Papias de Hierápolis e qualquer um dos apóstolos aqui, ainda que Eusébio relembre, no mesmo livro, uma antiga tradição vinculando o apóstolo Filipe e suas filhas profetisas à igreja desta cidade (cf. III.31.3-4). É de se notar, porém, que o historiador tinha sérias críticas a respeito da obra deste obscuro bispo da Ásia, principalmente no que tange sua escatologia milenarista (cf. III.39.12-13). Desse modo, ainda que anotando o fato de Irineu conectar Papias ao círculo do apóstolo João e de Policarpo de Esmirna, faz um esforço exegético a partir de seus próprios escritos para provar que não tinha sido uma testemunha da pregação dos apóstolos (III.39.1-2).
} 
testemunho prestado a Cristo" (III,36,3). Da seguinte forma descreve Eusébio a atitude de Inácio durante a viagem para o martírio:

Enquanto fazia a viagem através da Ásia, sob a maior vigilância dos guardas, fortalecia as Igrejas por meio de sermões e exortações, em todas as cidades por onde passava. Em primeiro lugar, acautelava-as contra as heresias que começavam a pulular; incitava-as a conservar firmemente a tradição dos apóstolos que, por segurança, julgou necessário fixar ainda por escrito. Estava já prestes a ser martirizado. (III,36,4)

Eusébio espelha na obra de Inácio as preocupações que, de certa forma, são o pano de fundo do seu próprio trabalho: o problema da conservação da "tradição dos apóstolos"

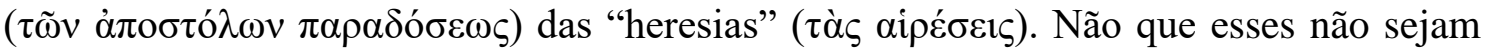
temas tratados pelo antioqueno em suas cartas. No entanto, é interessante que Eusébio seja o primeiro a anotar essa característica da pequena obra inaciana. Como visto anteriormente, Policarpo tem Inácio por exemplo de "perseverança" ( qualidade esta legada à posteridade por meio de suas cartas ${ }^{128}$; dessa forma, foca-se provavelmente no sofrimento do bispo em sua prisão e perspectiva de execução como mártir. Do mesmo modo, Irineu realça o Inácio mártir, sequer citando sua posição como bispo de Antioquia: o trecho da carta aos romanos citado expõe a expectativa quanto à sua execução na arena, não quanto a necessidade de se conservar a tradição apostólica dos ataques dissidentes (um problema fundamental também para Irineu, diga-se de passagem). Também Orígenes, como visto, ressalta Inácio na qualidade de bispo, mártir e, de certa forma, comentador dos eventos salvíficos registrados nos evangelhos. Eusébio vai além: Inácio é não apenas o bispo mártir sucessor de Pedro em Antioquia; é, também (e talvez, para ele, principalmente), um dos antigos defensores da tradição apostólica frente aos ataques primevos dos hereges que já começavam, desde Simão o $\mathrm{Mago}^{129}$, a corromper a unidade da Igreja de Cristo. Com o intuito de reforçar o seu trabalho, decide

\footnotetext{
${ }^{128}$ Tratando da cópia e transmissão das cartas de Inácio, Policarpo diz aos seus destinatários filipenses que

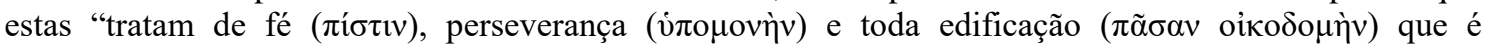
conveniente em nosso Senhor" (Pol.Fillipenses 13,2; Trad. EHRMAN, 2003: 351).

${ }^{129}$ Eusébio considera Simão o Mago o precursor dos grupos considerados como "heréticos" pela sua corrente do cristianismo, a mais difundida (cf. História Eclesiástica II.1.12). Outros autores (nos quais ele explicitamente se baseia) já haviam defendido essa tese antes. Hegésipo, citado por Eusébio (História Eclesiástica IV.22.5), coloca Simão logo no começo das dissidências, embora afirme ter sido precedido por Tebutis, um candidato frustrado a um episcopado não-referido. Já Irineu, escritor do qual Eusébio era grande depositário, afirma categoricamente ser Simão a origem de todas as heresias (Contra as heresias I.23.2).
} 
deixar seu testemunho do ensinamento dos apóstolos (o qual, pela lógica eusebiana, teria recebido de Pedro como seu segundo sucessor em Antioquia) por escrito, em cartas enviadas a igrejas.

Que cartas são essas? Para quais comunidades ele se dirige, segundo Eusébio? O historiador dá a resposta logo em seguida:

Assim, de Esmirna, onde se achava Policarpo, escreveu uma carta à Igreja de Éfeso, onde relembra seu pastor, Onésimo. Outra, à Igreja de Magnésia, às margens do Meandro, na qual cita também o bispo Damas. Outra, à Igreja de Trales, da qual se refere que tinha então Políbio por bispo. Além destas, escreveu também à Igreja de Roma, na qual a exorta a não tomar providências em vista de privá-lo do martírio, sua esperança e seu anelo. (III.36.5-6)

Temos por enquanto, portanto, quatro cartas referidas por Eusébio: aos efésios, aos magnésios, aos tralianos e aos romanos. Desta última, o historiador se dá ao trabalho (como é característico de sua obra) de citar literalmente um trecho inteiro, no qual Inácio ressalta sua condição de mártir próximo, assim como o destino que espera encontrar em Roma, ao fim de sua longa viagem pelo Mediterrâneo como prisioneiro:

Da Síria até Roma, luto contra as feras, por terra e por mar, noite e dia, preso a dez leopardos, isto é, uma escolta de soldados que se tornam piores quando bem tratados; mas sujeito a essas injustiças, torno-me cada vez mais discípulo; contudo, nem por isso sou justificado. Possa fruir das feras que me estão preparadas. Faço votos de encontrá-las bem alertas. Eu as provocarei para que me devorem rapidamente e não me façam como a alguns que elas hesitaram em tocar. Se não o quiserem, eu as forçarei. Perdoai-me; sei o que me é vantajoso. Agora começo a ser discípulo. Nada mais desejo das coisas visíveis e invisíveis, a fim de alcançar a Jesus Cristo: fogo, cruz, ataques das feras, ossos desconjuntados, membros amputados, corpo inteiramente esmigalhado, suplícios do diabo, tudo isso me sobrevenha contanto que obtenha a Jesus Cristo. (III.36.7-9)

Nas edições modernas da curta epistolografia inaciana, este longo trecho citado literalmente por Eusébio corresponde a In.Romanos 5. É a maior citação literal das cartas de Inácio feita até então, superando em muito as feitas por Irineu de Lyon e Orígenes. Serve, porém, fundamentalmente ao propósito tradicional da referência literária ao bispo 
de Antioquia: sua caracterização como o mártir ideal, aquele que põe por escrito seu desejo ardente de morrer testemunhando o nome de Cristo (em um tom que poderia francamente ser considerado como suicida). Tal preocupação de Eusébio faz-se mais compreensível tendo-se em conta o contexto no qual foram escritos os sete primeiros livros de sua História Eclesiástica. Certamente eles já se encontravam publicados no ano 303, quando Diocleciano dá início à maior perseguição aos cristãos vista até então no império; tal certeza se deve à forma como Eusébio indica, ao início do oitavo livro, que os livros posteriores são acréscimos considerados por ele convenientes para legar à posteridade a memória da violência desta última ação anticristã. Ainda durante o século III as igrejas em torno do Mediterrâneo haviam sofrido ataques mais sistemáticos por parte da autoridade imperial do que aqueles registrados nos dois séculos anteriores. Por mais que a segunda metade do século III (período da juventude e primeiras atividades de Eusébio, dentre elas o começo da escrita de sua História Eclesiástica) tenha sido um de relativa paz para as comunidades cristãs no império, a memória das perseguições recentes e dos que haviam tombado nelas encontrava-se viva entre os fieis, inclusive servindo de fomento a querelas acerca de como tratar aqueles que haviam sucumbido à pressão de oferecer culto considerado idolátrico pela Igreja. O bispo de Cesareia era seguidor de Orígenes, teólogo alexandrino para o qual, como visto anteriormente, o tema do martírio era particularmente caro.

Retornando, porém, ao problema central da transmissão e edição das epístolas de Inácio, a citação de tão grande trecho de uma delas por Eusébio serve como testemunho singular de sua difusão: a mesma carta anteriormente citada literalmente por um bispo na Gália é também citada por um bispo da Palestina, antes ainda da legalização do cristianismo por Constantino. É possível, portanto, que cópias das cartas de Inácio (ao menos aquela enviada aos romanos e, talvez, a aos efésios, uma vez que é citada por Orígenes, autor com forte conexão a Cesareia Marítima ${ }^{130}$ ) estivessem presentes na grande biblioteca de Cesareia administrada por Pânfilo, personalidade muito cara ao

\footnotetext{
${ }^{130}$ Outra carta também provavelmente em posse de Eusébio seria aquela destinada aos esmirniotas, da qual o historiador também cita literalmente um trecho, no capítulo 3 das edições modernas das cartas de Inácio: "Ele próprio, ao escrever aos esmirneus, emprega um dito cuja proveniência ignoro, afirmando a respeito de Cristo o seguinte: 'Quanto a mim, eu sei e creio que mesmo após a ressurreição, ele estava na carne. E aproximando-se de Pedro e dos que estavam com ele, disse-lhes: Pegai, tocai-me e vede que não sou um espírito incóporeo; e logo eles o tocaram e acreditaram"” (História Eclesiástica III.36.11).
} 
historiador ${ }^{131}$. As quatro cartas citadas até agora, porém, não são as únicas referidas por Eusébio. Em seguida à citação de In.Romanos 5, o historiador cita outras três:

Depois, já estando longe de Esmirna, de Trôade dirigiu-se por escrito aos de Filadélfia e à Igreja de Esmirna e particularmente a seu chefe Policarpo, que ele reconhecia ser inteiramente varão apostólico e a quem confiou seu rebanho de Antioquia, como a um verdadeiro e bom pastor, pedindo-lhe se dignasse ocupar-se dele zelosamente. (III.36.10)

Em conjunto com as referidas anteriormente, temos, portanto, sete cartas no total conhecidas de Eusébio de Cesareia: aos efésios, aos magnésios, aos tralianos, aos romanos, aos filadelfienses, aos esmirniotas e a Policarpo, bispo de Esmirna. Fechamos aqui o que concerne ao testemunho do bispo historiador. Outros escritores eclesiásticos dos séculos II e III d.C. citam Inácio de Antioquia e/ou suas cartas ${ }^{132}$, mas a informação que concedem vai pouco além daquela oferecida por Policarpo e Eusébio.

\footnotetext{
${ }^{131}$ Reforça este argumento o fato de Eusébio transmitir apenas informações sobre Inácio deduzíveis das próprias cartas (excetuando unicamente a afirmação de que ele seria sucessor de Pedro). Assim se pronunciam Moreschini e Norelli: "Eusebius derives his knowledge (sobre Inácio) from the letters themselves, of which he cites some passages" (MORESCHINI E NORELLI, 2005: 105).

${ }^{132}$ Dentre outros atores que fazem referência a Inácio de Antioquia, podemos citar Irineu de Lyon e Orígenes. Irineu faz referência ao antioqueno em sua obra maior, Contra as heresias: "Como disse alguém dos nossos condenado às feras, por causa do testemunho que prestou a Deus: 'Eu sou trigo de Cristo moído pelos dentes das feras para me tornar pão puro de Deus"' (Contra as heresias V.28,4). Em nenhum momento Irineu afirma explicitamente que o autor da dita frase é Inácio de Antioquia. Contudo, ela corresponde a In.Romanos 4,1 que temos em nossas edições modernas das epístolas inacianas. Salta aos olhos, no entanto, que o autor é referido pelo bispo de Lyon como alguém “condenado às feras": Inácio não é citado por sua autoridade como bispo de Antioquia, o que poderia ser considerado especialmente caro por Irineu, um defensor árduo da tese de que os bispos locais seriam sucessores dos apóstolos na conservação da tradição apostólica na Igreja. Ao invés, Inácio é somente citado como um mártir, possivelmente uma figura também especialmente cara a Irineu, que teria, não muito antes de escrever sua obra monumental, assistido a uma perseguição severa a seus correligionários no sul da Gália, como relatado por uma carta dos próprios perseguidos, conservada por Eusébio de Cesareia (citar Eusébio). Já Orígenes diz o seguinte, em suas Homilias sobre Lucas: "Encontrei uma afirmação elegante em uma carta de um mártir - falo de Inácio, o segundo bispo de Antioquia depois de Pedro. Durante uma perseguição, ele lutou contra animais selvagens em Roma. Ele afirmou, 'a virgindade de Maria fugiu ao conhecimento do senhor desta era"' (Homilias sobre Lucas 6,4; Trad: LIENHARD, 1996: 24). À semelhança de Policarpo, Orígenes refere-se a Inácio sobretudo como mártir, antes mesmo de situá-lo como bispo da importante igreja de Antioquia. Mesmo a tradição de que Inácio seria um sucessor do importante apóstolo Pedro no governo da mesma comunidade (tradição esta da qual Orígenes é a primeira testemunha conhecida) é citada apenas depois do autor referirse ao antioqueno como a um mártir . No entanto, diferente de Policarpo e semelhante a Irineu, e por estar expondo um comentário a um dos quatro evangelhos já quase universalmente reconhecidos como fundamentais, Orígenes preocupa-se também em citar Inácio, uma citação livre daquela que conhecemos como Carta aos Efésios (In.Efésios 19,1), pois considera que sua observação sobre o mistério da virgindade de Maria ao conceber o Cristo favorece uma melhor compreensão do começo do Evangelho de Lucas, que narra justamente a concepção virginal de Jesus e seu nascimento. Esse trecho da carta de Inácio aos Efésios é, portanto, o primeiro citado e vinculado explicitamente a ele por um autor do calibre de Orígenes.
} 


\subsection{3: As cartas consideradas autênticas pela maioria dos estudiosos}

Como pode ser notado logo de início, as cartas citadas por Eusébio encontram-se, ao menos em nome, no epistolário inaciano encontrado em uma série de manuscritos medievais. No entanto, nem todas as cartas que reclamam a autoridade de Inácio são referidas pelo bispo de Cesareia, a saber, aquelas aos tarsenses, aos antioquenos, a Hero, aos filipenses e a Maria de Cassobola. Isso significa que temos, em Eusébio, a referência a uma versão mais curta do epistolário. De princípio, tal fato não atestaria, por si só, a inautenticidade das cartas ausentes, mas simplesmente que o historiador havia tido contato com uma coleção mais curta, ainda que devamos recordar sempre o grande acesso que tinha Eusébio de Cesareia a escritos cristãos de séculos anteriores à sua época, muitos deles, inclusive, não mais existentes para nossa consulta (ao menos por enquanto!) ou sobreviventes apenas em fragmentos.

No entanto, a partir do século XVII, as cartas inacianas recebidas pelos séculos anteriores passaram a ser alvo de uma crítica textual de textos antigos em pleno desenvolvimento, sobretudo quando os mesmos eram envolvidos em disputas teológicas. O palco para o primeiro grande trabalho de edição crítica do epistolário de Inácio foi a Inglaterra de meados dos seiscentos, pelas mãos de James Ussher, um arcebispo anglicano (BRENT, 2009: 1-8). Movido pela defesa da estrutura hierárquica da Igreja da Inglaterra, que, aos olhos críticos puritanos, guardava semelhanças demais com aquela dos papistas, Ussher dedicou tempo ao estudo das cartas de Inácio, textos os quais encontravam-se no ponto central da querela. De fato, várias inteligências da parte puritana haviam colocado em xeque a autenticidade do referido epistolário, que era utilizado, tanto por anglicanos como por católicos, como um testemunho antiquíssimo da validade da hierarquia eclesial constituída por bispo, presbíteros e diáconos. Para tanto, dedicavam-se a uma crítica profunda do texto das cartas, identificando interpolações que simplesmente não poderiam ter sido obra de Inácio, o que provava sua inautenticidade e a impossibilidade de sua utilização em prol da defesa da hierarquia.

A resposta da parte de Ussher foi aceitar os argumentos críticos textuais puritanos, mas colocá-los sobre o plano de fundo do processo de transmissão dos textos. De fato, o bispo notou, em sua pesquisa, que vários estudiosos medievais ingleses citavam Inácio a partir de um texto bem diferente daquele recebido em seu tempo, dos quais destacavamse Robert Grosseteste, John Tyssington e William Wodeford. A partir da comparação textual, Ussher advogou a tese de que deveria existir uma versão das cartas de Inácio livre 
das interpolações do texto comumente recebido. Publicada em 1644, a tese de Ussher permaneceria no âmbito do hipotético se, apenas dois anos depois, outro estudioso, Isaac Voss, não publicasse uma versão grega de seis cartas de Inácio, retiradas de um códice encontrado em uma biblioteca de Florença, na Itália. Essas cartas formam o que é conhecido academicamente como a "recensão média das cartas de Inácio de Antioquia", isto é, todas aquelas citadas por Eusébio de Cesareia, excetuando a dirigida aos cristãos romanos, encontrada em uma tradição manuscrita diferente.

A preferência pelo uso estrito da recensão média se confirmaria com o trabalho de um estudioso inglês do século XIX, John Barber Lightfoot, que publicou, em conjunto com uma extensa análise crítica, a mesma recensão média advogada por Ussher e publicada por Voss, com o acréscimo de In.Romanos. O trabalho de Lightfoot serve, ainda hoje, de base para todos os trabalhos sobre Inácio de Antioquia, inclusive pelos poucos que criticam seu estudo e a opção pela recensão por ele advogada (SCHOEDEL, 1985: 2). Em seu estudo, Lightfoot visou demonstrar como as cartas reunidas na recensão média, quando retiradas várias interpolações claras, apresentam uma unidade de ideias, estilo e vocabulário, com uma notória escassez de citações escritos tanto do Antigo quanto do Novo Testamento. O estudioso conclui, a partir daí, que a tais cartas deve ser conferida e aceita a autoria da parte de Inácio, ao passo que aquelas não citadas por Eusébio deveriam ser inseridas em um grupo a parte de documentos consideravelmente posteriores (talvez mesmo do século IV d.C.) que meramente reivindicam a autoridade do antioqueno.

Alguns estudiosos, como já referido brevemente, voltaram a atacar a autenticidade de parte da recensão média, por vezes advogando a autoria inaciana apenas para um grupo de cartas conhecido como "recensão curta", ou mesmo negando a autoria de Inácio para qualquer uma das cartas existentes levando seu nome. No primeiro caso, a base para a argumentação em prol de uma versão mais curta do epistolário é a existência de um manuscrito de língua síria contendo uma versão abreviada de In.Policarpo, In.Efésios e In.Romanos, junto com um parágrafo de In.Tralianos (SCHOEDEL, 1985: 3) ${ }^{133}$. Na opinião de Schoedel, porém, a tese mais digna de atenção nesse sentido é a advogada por Robert Joly, segundo o qual toda a coleção média deveria ser considerada uma falsificação de c. 160-170 d.C., visando, obviamente, a defesa da hierarquia eclesiástica em ascensão no segundo século da era cristã. $\mathrm{O}$ argumento fundamental de Joly encontra-

133 Uma boa síntese das visões opostas à autenticidade da recensão média, em conjunto com uma aprofundada refutação das mesmas, pode ser encontrada em BRENT, 2009: 95-143. 
se na incompatibilidade entre o cenário pressuposto pelas cartas inacianas e o cristianismo de inícios do século II d.C., considerando ele anacronismos claros termos utilizados por Inácio como "cristianismo", "católico" (embora nós mesmos traduzamos a palavra de forma diferente, mais à frente) e "homilia". No entanto, o erro crasso de Joly é pressupor um quadro para o cristianismo asiático diferente daquele discernível a partir das cartas de Inácio sem possuir uma bagagem documental suficiente para tanto. De fato, ele quer enxergar, no texto de Inácio, o "bispo" onde talvez devêssemos traduzir meramente como "supervisor", como viemos fazendo até aqui com outros documentos de alguma forma vinculados ao cristianismo asiático, como os Atos dos Apóstolos e 1Timóteo, assim como com a carta de Paulo aos cristãos filipenses. Como visamos explicitar por meio do presente capítulo, o "supervisor" referido por Inácio está longe de reunir em si o poder reivindicado pelos bispos da segunda metade do mesmo século, assim como não existe

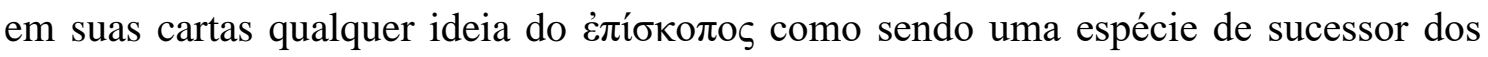
apóstolos. Em outras palavras, objetivando denunciar o anacronismo no documento, Joly consegue apenas demonstrar o anacronismo em sua própria leitura crítica.

Deste modo, seguimos com a maioria dos estudiosos em seu consenso. As cartas que são analisadas no capítulo 3 como sendo de autoria do próprio Inácio de Antioquia são: Efésios, Magnésios, Tralianos, Romanos, Filadelfienses, Esmirniotas e Policarpo.

\section{2: Quem era Inácio de Antioquia?}

Ao contrário de Paulo de Tarso, cujas cartas analisamos no segundo capítulo, Inácio de Antioquia não foi personagem de nenhuma escrita histórica ou biográfica por um contemporâneo seu. Do mesmo modo, em suas cartas, ele se importa muito mais em exortar seus destinatários acerca de problemas de suas próprias comunidades, do que em dar informações específicas de sua vida e de sua trajetória. Assim, as informações que temos acerca de Inácio são pouquíssimas, limitando-se, em geral, ao seu processo de transferência a Roma como prisioneiro, aguardando (ou esperando) a morte.

Em algum momento incerto nas primeiras duas décadas do século II, os soldados que escoltavam Inácio de Antioquia e outros prisioneiros (Policarpo aos Filipenses 13,2; não se sabe ao certo se apenas prisioneiros cristãos se encontravam no comboio) se defrontaram com algum tipo de "atraso" (SCHOEDEL, 1985: 11; TREBILCO, 2004: 628) que os fez permanecer por um tempo relativamente prolongado em Esmirna, um dos

principais centros urbanos da província da Ásia, talvez por volta do fim de agosto, data 
da escrita de sua carta aos cristãos de Roma (Romanos 10,3) ${ }^{134}$. Permanecendo por lá um tempo considerável, Inácio tem a oportunidade de receber delegações provenientes de igrejas de cidades diversas mesmo sendo prisioneiro, embora Trevett aponte não ser isso algo particularmente impressionante (TREVETT, 1992: 4). As que conhecemos com certeza são: Éfeso, Magnésia e Trales. A posição dos visitantes dentro da hierarquia comunitária é variada, mas um detalhe chama a atenção: todas as delegações tinham à sua frente um supervisor. Seus nomes são conhecidos: Onésimo de Éfeso, Damas de Magnésia e Políbio de Trales. Em seguida, o pelotão que levava Inácio fez parada em Trôade, a qual aparentemente foi mais curta (SCHOEDEL, 1985: 11). Daí, ocorre uma saída abrupta para Neapolis, na costa macedônica, referida em In.Policarpo 8,1. A última notícia que temos de Inácio é a de que ele chegou a passar por Filipos, na mesma região, para cuja comunidade Policarpo de Esmirna escreveu, recordando o fato (Policarpo aos Filipenses 9,1). Daí provavelmente foi levada pela Via Egnatia até a costa adriática, de modo a ser despachado para a Itália e alcançar Roma, após longa viagem por grande parte do Mediterrâneo oriental. São essas as circunstâncias das quais se origina a documentação que analisamos aqui. Mas quando se deu tal acontecimento? Por que Inácio era levado como prisioneiro?

Apesar da inexistência de evidências diretas relativas aos precedentes da prisão de Inácio de Antioquia (ou mesmo de qualquer aspecto de sua vida anterior ao momento em que escreve), é considerado um consenso acadêmico a existência de divisões na igreja de Antioquia durante a atividade do mártir (ROBINSON, 2009: 111). A hipótese foi defendida pela primeira vez por P. N. Harrison (HARRISON, 1936: 79-106) a partir de um exame minucioso das palavras usadas por Inácio antes de receber a notícia da "paz" recuperada em Antioquia e depois (Filadelfienses 10,1; Esmirniotas 11,2; Policarpo 7,1). Analisando detidamente os trechos em que Inácio comemora o retorno da paz à sua igreja de origem e requisita das comunidades de Filadélfia e Esmirna o envio de representantes para congratular seus membros, Harrison nota que os termos utilizados pouco se

\footnotetext{
${ }^{134}$ Brent defende que o fato de Inácio indicar que escreveria novamente aos efésios se o Senhor lhe revelasse que eles se encontravam em boa ordem (Efésios 20,1-2) apontaria para a proximidade de sua partida de Esmirna para Trôade no momento em que escreve (BRENT, 2009: 145). No entanto, ele se utiliza de um manuscrito diferente do preferido por Schoedel nesse trecho. O manuscrito utilizado por Schoedel não traz uma vinculação necessária entre a revelação pretendida por Inácio e a boa ordem que ele espera dos efésios. Ele nota que essa tradução é preferível considerando-se a improbabilidade de Inácio imaginar, nas condições em que se encontrava, que poderia escrever novamente após receber novas notícias da parte dos efésios (SCHOEDEL, 1985: 96). Schoedel deixa escapar, porém, o caráter profético pretendido por Inácio

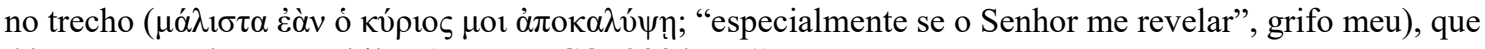
é bem capturado por Trebilco (TREBILCO, 2004: 671).
} 
encaixam em um contexto de perseguição generalizada cessada, conforme a interpretação tradicional (Eusébio de Cesareia, História Eclesiástica III.36.3), mas que indicariam mais provavelmente um de fortes divisões internas.

O principal trecho que apoia a tese de Harrison é Esmirniotas 11,2, no qual Inácio diz que os cristãos de Antioquia agora "estão em paz e retomaram sua grandeza e

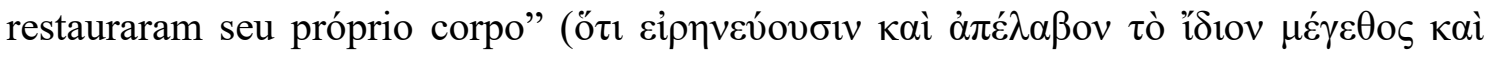

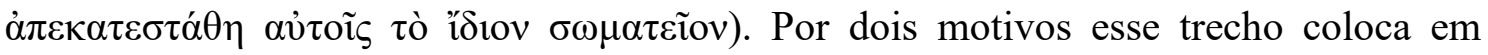
cheque a tese de que Inácio se referiria à cessação de uma perseguição: em primeiro lugar,

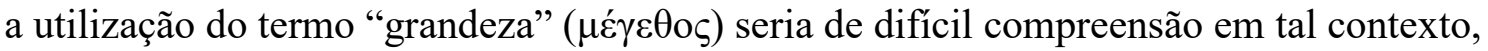
considerando-se que, para o antioqueno (especialmente na situação em que se encontrava), é justamente na perseguição que o cristianismo pode alcançar sua grandeza (Romanos 3,3); em segundo lugar, como anota Schoedel (SCHOEDEL, 1985: 250-1), a

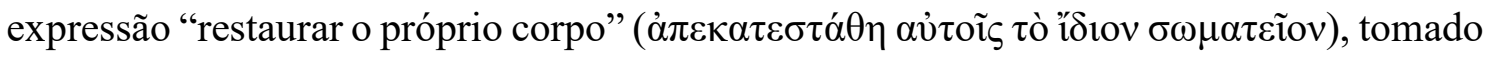
em sentido coletivo, denota com maior frequência nos documentos greco-romanos a restauração de uma governança em determinada comunidade. Brent, por seu lado, nota que, nos escritos cristãos antigos, o "recuperar a paz" em geral refere-se ao fim de uma disputa interna à comunidade cristã (BRENT, 2009: 21).

No entanto, teria uma provável crise interna à comunidade de Antioquia alguma relação com a prisão de Inácio? Allen Brent chegou a pensar que sim, indo, inclusive, além, ao buscar retirar das próprias cartas inacianas a razão por trás do encarceramento: um conflito no qual o ponto nodal era a defesa intransigente de Inácio do caráter elevado de sua posição enquanto supervisor da igreja local (Brent traduz como "bispo"; Ibidem: 14-37). As bases da tese de Brent, contudo, são consideravelmente frágeis. Para chegar a tal conclusão, ele aceita um estudo de John P. Meier sobre a igreja de Antioquia durante o século I d.C., o qual lança mãos do Evangelho de Mateus e a Didaché para reconstruir a história do grupo no último terço do mesmo século (MEIER, 2004: 12-86). Uma vez que ambos os documentos parecem advogar a supremacia de uma outra forma de autoridade, vinculada à oralidade (apóstolos, profetas e doutores), a iniciativa de Inácio de afirmar a centralidade de seu cargo de supervisor certamente teria causado instabilidade interna. Contudo, embora a tese de Brent não seja improvável, devemos recordar o que foi dito no capítulo 2 acerca da visão geral dos acadêmicos do século XX (também de Meier) a respeito da abordagem metodológica a ser utilizada na análise dos evangelhos e as críticas que fizemos à mesma. Meier não apenas considera que pode reconstruir uma comunidade e sua história a partir de um evangelho (e da Didaché, que 
lhe é literariamente dependente em muitos trechos), como crê poder identificar o local de sua escrita como sendo Antioquia, o que também não pode ser comprovado, considerando a tese de Bauckham que adotamos aqui.

Deste modo, as únicas notícias relativamente certas que temos acerca do cristianismo antioqueno até a época de Inácio se encontram em uma carta de Paulo aos fieis da Galácia e nos próprios Atos dos Apóstolos, com os quais trabalhamos longamente no capítulo 2. No entanto, a maior parte das informações aqui se referem a um período muito anterior ao de Inácio, apenas até meados do século I d.C., embora possamos ressaltar três pontos em particular: o primeiro, é que a igreja antioquena, segundo os Atos e Gálatas, contava com um forte contingente de cristãos advindos do politeísmo já bem cedo, antes mesmo das viagens de Paulo; o segundo, é que também contava com um considerável contingente de cristãos judeus, assim como teria sido palco de intensos conflitos acerca da convivência entre os dois grupos, inclusive com uma discussão acalorada entre Paulo e Pedro, um dos principais discípulos de Jesus; o terceiro é que, segundo os Atos dos Apóstolos, os profetas, em conjunto com mestres, aparentemente possuíam uma importância considerável no cristianismo local, partindo daí, provavelmente, as tradições a respeito mantidas por Paulo em suas igrejas na Ásia Menor e na Grécia.

Não podemos dizer com certeza que o conflito interno à igreja de Antioquia e o suposto papel de Inácio nele sejam uma razão concreta para o mesmo ser encarcerado, apesar de toda a atratividade da proposta de Brent. O mais provável é que a acusação oficial contra Inácio fosse a de ser cristão, conforme ele mesmo deixa a entender em In.Efésios 1,2, onde diz ter sido "posto em correntes pelo nome e esperança comuns" ( $\tau$ oṽ

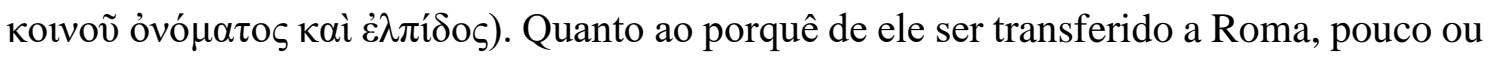
nada se sabe, embora Stevan L. Davies (DAVIES, 1976: 175- 180) e Allen Brent (BRENT, 2009: 14-9) tenham demonstrado que tal quadro, apesar de raro, não era impossível conforme a jurisprudência romana, principalmente se a prisão de Inácio houvesse ocorrido, como defende Davies, por volta de 113 d.C., quando da ausência de um governador na Síria para lavrar sua sentença de morte (neste caso, Inácio teria sido transferido a Roma não com uma condenação pronta, mas uma mera recomendação). Trevett, ao invés, prefere escolher data mais antiga, apoiando-se em um testemunho de Eusébio em seu Chronicon e de Duas Atas de martírio de Inácio: 107 d.C. (TREVETT, 1992: 9). De qualquer forma, podemos afirmar com certa segurança que a atividade do 
antioqueno se deu, sobretudo, nas primeiras décadas do século II d.C., podendo talvez ser incluída a última década do século I d.C. também.

Para além desses pontos, pouco mais pode ser levantado sobre Inácio de Antioquia, além do seguinte: ele afirmava ser o supervisor único da igreja de Antioquia; ele certamente possuía formação literária, devido à sua facilidade de mesclar elementos das epistolografias helenista e cristã, demonstrando em vários momentos dotado de grande criatividade e originalidade ${ }^{135}$; muito provavelmente era de origem pagã, uma vez que não aparenta ser tão versado nas escrituras judaicas quanto demonstra ser com os escritos de Paulo; mesmo no último caso, a única carta de Paulo à qual cita literalmente com alguma frequência é 1Coríntios; e, por fim, aparentemente Paulo era um modelo que queria seguir, considerando-se inclusive seu "discípulo"136. Inácio de Antioquia é, em suma, uma figura representativa e relativamente comum do ambiente da metrópole síria de sua época, um caldo de culturas diversas, na qual a educação helênica possuía uma posição de destaque ${ }^{137}$.

\section{3: Aspectos importantes da retórica inaciana}

Ao escrever suas sete cartas, Inácio de Antioquia possuía uma agenda em mente: queria defender de todas as formas limitadas possíveis, considerando sua situação delicada, a unidade das comunidades cristãs às quais se dirigia. Não queria qualquer

\footnotetext{
${ }^{135}$ Em parte considerável de suas cartas, Inácio parece se inspirar nas cartas paulinas, inclusive como deixa subentendido aos cristãos tralianos: “... à qual (igreja) também cumprimento na plenitude, em caracteres

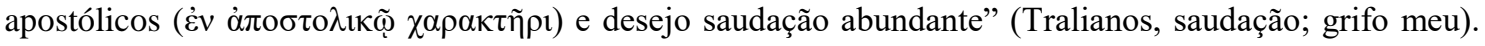
Ao mesmo tempo, porém, mostra-se muito criativo, trabalhando independentemente com fórmulas helenísticas e cristãs. As grandes saudações, por exemplo (como a dirigida aos romanos), são incomuns às cartas contemporâneas às suas, afora as de Paulo (cf. Ro 1,1-7; 1Co 1,1-3; Ga 1,1-5). No entanto, os temas das saudações inacianas não seguem cegamente as paulinas, mas são compostas livremente por ele. Tudo isso sugere a extraordinária capacidade comunicativa de Inácio, principalmente considerando que tamanha criatividade encontrava-se em operação em ambiente claramente hostil (a prisão), provavelmente sem poder ter acesso a qualquer material com o qual fosse familiarizado (como manuais, por exemplo). O supervisor cristão de Antioquia, naquela que considerava ser sua viagem para a morte, esforçava-se para comunicarse de forma efetiva com os seus destinatários, de modo que eles acolhessem de fato o que dizia em sua condição de mártir próximo: "Eu sou uma expiação daqueles que são sujeitos ao bispo, aos presbíteros e aos diáconos" (Policarpo 6,1). Imagens fortes como essa são evocadas por Inácio em diversos momentos nas cartas, um complemento à força de sua própria figura de homem "acorrentado por causa do nome" (Efésios 3,1). Cf. SCHOEDEL, 1985: 7.

${ }^{136}$ A condução de Inácio de Antioquia poderia ser encarada como um indício de que ele fosse um cidadão romano que havia se utilizado de seu direito de provocatio, conforme a Lex Iulia de ui publica. Trevett, no entanto, descarta tal possibilidade: além de ser deveras estranho um cidadão romano sendo levado "acorrentado" até Roma e com risco (segundo ele) de ser morto por "fogo, feras", Inácio dificilmente optaria por um novo julgamento pelo César, já que ele toma todas as provisões para justamente não ser salvo! Ver TREVETT, 1992: 5.

${ }^{137}$ Para uma narrativa mais profundada sobre Antioquia desde sua fundação até a época de Inácio, ver ROBINSON, 2009: 1-39.
} 
forma de unidade, porém, mas unicamente aquela decorrente da submissão de todos os fieis de uma mesma pólis ao seu único supervisor. A construção ideal, por parte de Inácio, de como uma tal unidade deveria ser pensada e, sobretudo, os efeitos práticos de tal ideal serão analisados na seção 3.4. Antes, porém, precisamos abordar alguns meios retóricos essenciais dos quais o autor prisioneiro lança mão para fazer com que sua mensagem seja ouvida por aqueles aos quais escreve, no contexto próprio no qual viviam sua fé, com suas próprias visões de ideal de vida cristã e liderança da comunidade.

\subsection{1: Abordagem crítica cautelosa}

Em sua carta aos cristãos de Éfeso, Inácio escreve em determinado momento: "Consequentemente é certo que corrais juntos com o propósito do supervisor, o que de

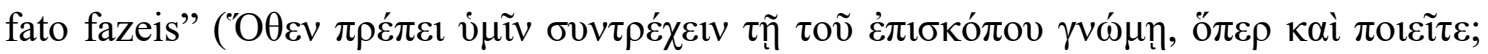
In.Efésios 4,1; grifo meu). Aos de Esmirna, tratando daqueles que professavam que o Cristo havia vindo ao mundo apenas em aparência, expressa-se de forma parecida: " $\mathrm{E}$ essas coisas vos advirto, amados, sabendo que vós também tendes o mesmo pensamento"

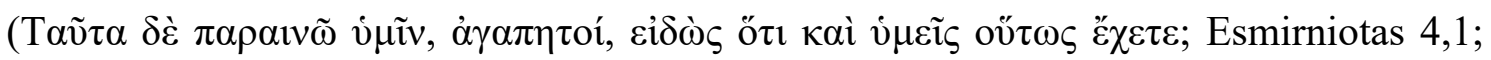
grifo meu). Já retornando ao tema da necessidade dos dirigentes comunitários para a existência da igreja, desta vez aos cristãos tralianos, diz: "Sem esses (supervisor, anciãos e servidores), (a comunidade) não se pode chamar igreja. Sobre isso estou persuadido de

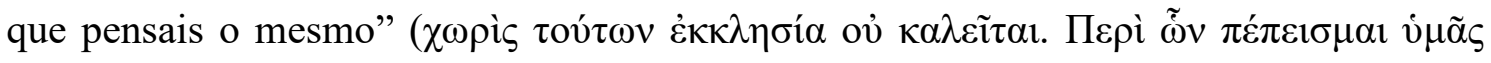
oü $\tau \omega \varsigma ~ \check{\varepsilon} \chi \varepsilon ı$; In.Tralianos 3,1-2; grifo meu). Aparentemente, conforme as palavras de Inácio, tudo ocorre bem nas ditas igrejas, conforme as suas perspectivas. No entanto, por quê o bispo vê a necessidade de tratar desses assuntos, mesmo afirmando que não são os seus destinatários os alvos da crítica? Uma resposta que pode surgir imediatamente é: os problemas aos quais Inácio se refere foram enfrentados por ele em Antioquia, de modo que, passando pela Ásia e visando deixar um último conselho para os cristãos locais, adverte seus leitores do perigo que pode estar chegando por aquelas regiões. De fato, é isso que Inácio parece afirmar na sequência do trecho de sua carta aos esmirniotas citado acima: “...mas eu estou vos protegendo de antemão de feras em forma humana"

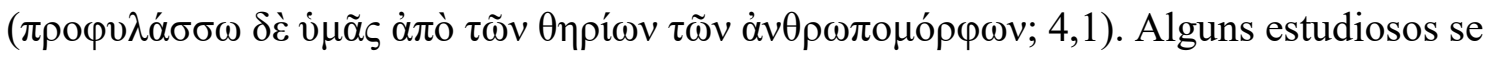
inclinaram a essa linha de visão, considerando que, a partir de trechos como esse, seria possível reconstruir algo do ambiente social e comunitário cristão do qual teria saído o supervisor cristão de Antioquia. 
Quando analisadas mais a fundo, porém, as cartas parecem indicar o contrário: por vezes Inácio deixa a entender justamente que existem os ditos problemas nas igrejas às quais se dirige, ainda que, falando de forma explícita, prefira dizer que não (TREBILCO, 2004: 635). Tomemos alguns dos trechos citados no parágrafo anterior como exemplo. Foi anotado que, ao dirigir-se aos cristãos de Esmirna, Inácio afirma que aqueles aos quais ataca, ou seja, os que creem que Cristo teria passado pelo mundo apenas em aparência, não passaram ainda pela igreja à qual escreve, afirmando estar apenas advertindo-os de antemão. Ora, em outro momento na mesma carta, Inácio diz que: "Seus nomes, que são infiéis, não me parece correto anotar. De fato, eu preferiria sequer recordá-los enquanto não se arrependerem no que concerne à paixão (de Cristo), que é a nossa ressurreição" (In.Esmirniotas 5,3). Aqui, ele deixa transparecer que seus destinatários, os cristãos de Esmirna, sabem muito bem de quem ele está falando. Na verdade, ao que parece, provavelmente os acusados de desvios doutrinários estiveram dentre aqueles que visitaram-no (com maior ou menor frequência, não é possível afirmar com certeza) na prisão durante sua estadia em Esmirna, uma vez que Inácio conhece seus nomes e sabe muito bem de quem está falando e quais são os riscos que carregam em sua defesa de visões teológicas errôneas (algo que, pelo que sugere a advertência inaciana, poderia não estar tão claro para os seus destinatários). O mesmo problema encontramos na carta dirigida aos cristãos tralianos. Nesse documento, Inácio diz estar persuadido de que seus leitores concordam com ele no que tange o caráter fundamental da existência de um supervisor, anciãos e servidores em uma igreja que queira chamar-se "igreja". No entanto, o tom das frases do bispo em outros trechos parece indicar que tal concordância não seria tão generalizada e que ele sabia disso. Em In.Tralianos 7,2 encontra-se escrito que: “Aquele que está dentro do altar está puro - isto é, aquele que faz qualquer coisa sem supervisor, colégio de anciãos e servidores, não está puro em consciência" (ó દ̇viò

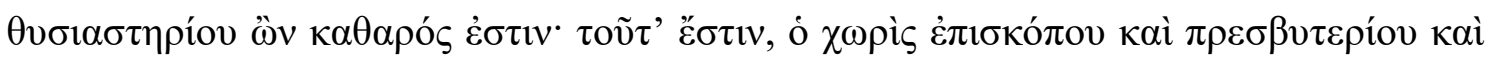

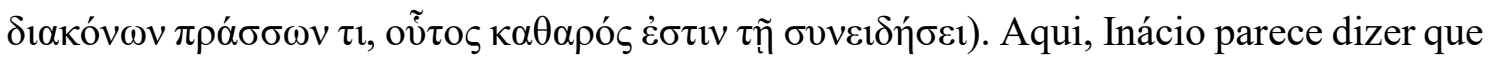
nem todos aos quais se dirige estão puros, pois alguns insistem em se reunir fora do “altar”, ou seja, a reunião em presença da hierarquia dirigente. Isso é reforçado em outro momento, quando o autor insiste que seus destinatários sejam sempre assíduos em dar assistência ao seu supervisor, acrescentando depois: "Peço que me ouçais no amor, para

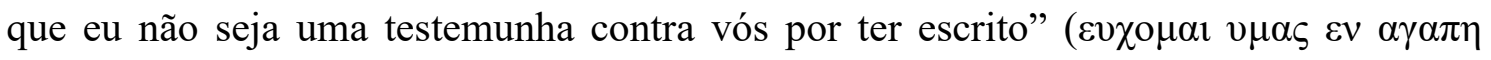

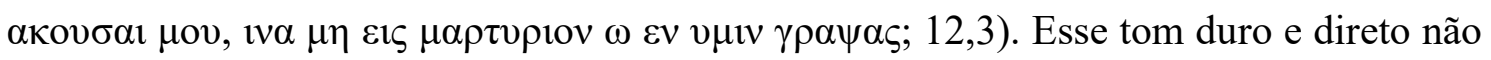


é encontrado nas outras cartas, o que sugere que Inácio vê no caso traliano um motivo especial de preocupação e uma boa razão para ser mais incisivo em sua exortação.

Em ambas as cartas citadas, portanto, o fato de Inácio afirmar que os problemas aos quais se refere não se encontram entre seus destinatários não deve nos levar a pensar que fosse esse realmente o caso. Na verdade, ocorre o contrário: são justamente esses problemas que ele identifica nas comunidades às quais se dirige, e isso se torna ainda mais evidente quando notamos que para cada comunidade a exortação é orientada para uma questão diferente. Se, nesses casos, Inácio estivesse buscando advertir de antemão seus destinatários acerca de problemas enfrentados por ele em Antioquia, por quê não tratar de todos em cada carta?

O que ocorre então? Inácio, ao dirigir-se aos seus leitores, identifica alguns problemas existentes entre os mesmos (muito provavelmente a partir de informação mediada por aqueles membros das respectivas igrejas que o estão visitando na prisão em Esmirna), trata deles em suas cartas, mas não de forma aberta e direta. Antes, aborda-os como realidades alheias (mas não menos perigosas) deixando como pressuposto da comunicação que seus leitores concordam com ele a seu respeito. Dessa forma, o supervisor antioqueno consegue suavizar o que poderia ser, em outro caso, uma recomendação mais severa (SCHOEDEL, 1985: 51). Nesse ponto, Inácio não se encontra isolado no âmbito literário greco-romano (TREBILCO, 2004: 635). Demóstenes afirmava que uma das funções do orador era "ver as coisas tomando lugar, prever o que está vindo e prevenir os outros" (Coron. 246). Um paralelo pode ser encontrado no Papiro Freiburger 39: "Portanto rogo-te com seriedade e exorto-te para que tomes bom cuidado com meu cavalo, como de fato sempre fazes, e agradeço-te profusamente e agradecerei novamente...” (apud SCHOEDEL, 1985: 51).

Inácio, portanto, não se sente à vontade e em posição de fazer uma reprimenda severa a destinatários que desconhece pessoalmente (excetuando os de Filadélfia e Esmirna) e utiliza um artifício retórico relativamente comum ao seu tempo para fazer uma recomendação suavizada, mas importante, aos mesmos. Apesar de poder parecer apenas um detalhe de oratória nas cartas inacianas, a identificação desse instrumento possui um valor heurístico enorme para a reconstrução (ainda que parcial) das comunidades com as quais o bispo prisioneiro se comunica, especialmente no que tange possíveis tensões e conflitos subentendidos. Pode ser considerada aquele indício, o "dedo de Perugino" ao qual se refere Ginzburg, utilizando o exemplo de Morelli (GINZBURG, 1989: 144). Se cairmos no truque de Inácio, como fizeram alguns outros autores, teremos de considerar 
todos os ditos problemas como alheios àquelas comunidades que são nosso objeto de estudo, aceitando que eles são apenas perigos contra os quais ele pretende deixar seus leitores advertidos. Se, por outro lado, aceitamos a existência desse artificio retórico nas cartas, então a perspectiva se altera consideravelmente: existem tensões nas igrejas da Ásia e elas envolvem, em grande parte, as pretensões do supervisor cristão de cada cidade, como veremos em mais detalhes à frente. Mesmo considerando-se um mártir próximo, Inácio não toma para si a pretensão de acusar aberta e diretamente seus leitores, ou mesmo de identificar quais são os elementos problemáticos (como em In.Esmirniotas 5,3), considerando-se que talvez nem todos os seus destinatários eram visados pela crítica velada. Pelo contrário, quando decide adverti-los claramente, atribui não a si mesmo a autoria das palavras, mas ao Espírito Santo (In.Filadelfienses 7,1-2). Muito provavelmente a sua insegurança não se restringia a preocupações com relação a sua credibilidade ou aceitação por parte de seus leitores (principalmente tendo-se em conta que ele esperava a morte próxima), mas se estendia à garantia de que suas cartas não se tornassem motivo de abalo à possivelmente já frágil posição dos seus colegas supervisores: esses eram a principal mediação entre suas respectivas comunidades e o prisioneiro, principalmente no que tange à informação. Se chegasse aos cristãos efésios, por exemplo, uma carta com duras críticas a respeito de assuntos que dificilmente poderiam ser conhecidos pelo antioqueno a não ser pela boca de seus representantes enviados (entre eles, o supervisor), não seria difícil imaginar a situação complicada na qual estaria metido Onésimo, o supervisor da comunidade de Éfeso. A experiência de Inácio com a comunidade de Filafélfia já lhe havia esclarecido que apelações a uma revelação divina poderiam não surtir efeito:

Quando no meio de vós, eu gritei, falei em voz alta - a voz de Deus: “Assisti ao supervisor, ao colégio dos anciãos e aos servidores". Aqueles que suspeitaram de mim de que eu teria dito isso porque teria informação de antemão da divisão de alguns - ele (Deus) é minha testemunha em quem estou acorrentado de que eu não o soube de nenhum ser humano. Foi o Espírito que proclamou, dizendo essas palavras... (In.Filadelfienses 7,1-2).

\subsection{2: Invocação de seu caráter de mártir próximo}

Outra peculiaridade do discurso de Inácio deve ser destacada, uma vez que possui fundamental importância para a abordagem que visa fazer junto às comunidades cristãs 
asiáticas as quais se dirige. Embora, como visto anteriormente, não haja nada de realmente concreto na documentação que indique que ele já houvesse saído de Antioquia com uma condenação à morte (especialmente se considerarmos que ele aparenta crer realmente que os cristãos romanos pudessem fazer algo para reverter seu quadro; ver In.Romanos 2-3), ele claramente visa passar a seus destinatários a imagem de que quem lhes escreve é alguém marcado para morrer pela fé comum em Cristo, logo ao fim daquela viagem que o havia levado até aquela região. Os meios e os objetivos com os quais ele instrumentaliza retoricamente sua condição de prisioneiro rumando para a morte podem ser divididos, basicamente, em três: um autorebaixamento para conquistar a simpatia do leitor; uma caracterização de sua viagem como uma grande procissão cultual, na qual ele é o sacrifício a ser oferecido a Deus para a unidade interna às igrejas, com a submissão de todos os fieis ao supervisor de sua comunidade; como refutação aos docetistas.

\subsubsection{1: Autorrebaixamento}

Rebaixar-se em comparação ao(s) destinatário(s) ou ao(s) ouvinte(s) era uma prática consideravelmente comum e bem conhecida da retórica ensinada à época de Inácio (ISACSON, 2004: 73). Adepto como era do estilo de discurso asiático, no qual o orador carregava suas sentenças de sentimento de modo a cativar mais facilmente a plateia, o rebaixamento que o supervisor faz de si mesmo envolve o drama de sua prisão. Ao mesmo tempo, porém, tal artifício possui o efeito contrário (e visado) de realçar a singularidade da situação do autor. Uma passagem bem representativa neste sentido é a de In.Efésios 3,1 :

Não vos vou ordens como se fosse alguém; pois ainda que eu tenha sido acorrentado no nome, ainda não fui aperfeiçoado em Jesus Cristo. De fato, agora eu apenas comecei a ser um discípulo, e eu vos falo como a meus coaprendizes; pois eu preciso ser untado pela vossa fé, admoestação, perseverança, paciência. (Trad.: SCHOEDEL, 1985: 48)

O trecho é representativo por duas razões. Em primeiro lugar, Inácio coloca como pressuposto que o fato de estar "acorrentado no nome" (isto é, preso por ser cristão) é reconhecido por seus destinatários como uma condição especial para um cristão estar. $\mathrm{O}$ Apocalipse de João é bem ilustrativo do pensamento que corria pelo cristianismo asiático quanto ao sofrer "pelo nome". Em uma de suas visões, o profeta João descreve uma 
multidão diante do "trono do Cordeiro", trajando "vestes brancas e com palmas na mão" (Apocalipse 7,9). A descrição serve de pretexto para o autor caracterizar os cristãos presos e/ou executados:

Ele [um ancião], então, me explicou: Estes são os que vêm da grande

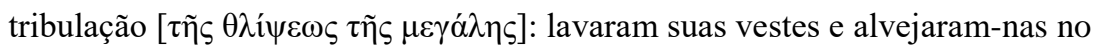
sangue do Cordeiro. É por isso que estão diante do trono de Deus, servindo-o

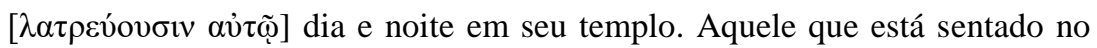
trono estenderá sua tenda sobre eles: nunca mais terão fome, nem sede, o sol nunca mais os afligirá, nem qualquer calor ardente; pois o Cordeiro que está no meio do trono os apascentará, conduzindo-os até às fontes de água da vida. E Deus enxugará toda lágrima de seus olhos. (Apocalipse 7,14-17)

É notório que o sofrimento "pelo nome" era colocado na mais alta conta por João em seu escrito, destinado a comunidades cristãs da Ásia, e ele aparentemente não se encontrava isolado neste sentido. Se considerarmos 2 Timóteo como sendo um escrito ao menos relacionado ao cristianismo asiático (como discutido no capítulo 2), temos nele uma representação, produzida na primeira pessoa do singular, de um Paulo prestes a morrer por sua fé e apresentando as consequências de sua morte próxima:

Fiel é esta palavra: Se com ele [Cristo] morremos, com ele viveremos. Se com ele sofremos, com ele reinaremos. Se nós o renegamos, também ele nos renegará. Se lhe somos infiéis, ele permanece fiel, pois não pode renegarse a si mesmo. (2Timóteo 2,11-13) ${ }^{138}$

Segundo o que pode ser visto a partir dos dois trechos citados, Inácio tinha todos os motivos para considerar que os cristãos efésios consideravam-no, no mínimo, um homem singular, seja porque conhecesse Apocalipse e 2Timóteo (o que não é certo, considerando que não os cita claramente em nenhum lugar em suas cartas), seja por conta de seu contato com os representantes enviados pela igreja efésia. Não só no caso de Éfeso, mas de outras comunidades às quais se dirige, como pode ser visto em: In.Magnésios 12; In.Tralianos 5,2; In.Filadelfienses 5,1; e In.Esmirniotas 5,2.

A segunda razão pela qual o trecho citado é representativo é o contraponto criado por Inácio: se os seus destinatários o colocavam em um pedestal, ele apresenta razões

138 Nosso ponto é reforçado se, com Wild, considerarmos o trecho citado "um hino usado nas igrejas paulinas" (WILD, 2011: 651). 
para que eles não se considerassem rebaixados, de modo a conquistar-lhes a simpatia. No caso de Éfeso, por exemplo, ele lança mão da importância histórica do grupo cristão aí presente, conforme pudemos ver no capítulo 2: não é Inácio quem, a princípio, deve admoestar e exortar os cristãos efésios e sim o contrário, ainda que ele mesmo não obedeça tal regra pelo "amor que não o permite silenciar-se" (In.Efésios 3,2). A mesma estratégia é utilizada pelo autor em In.Magnésios 11,12, onde ele contrapõe sua condição de preso e a liberdade desfrutada por aqueles com os quais se comunica.

\subsubsection{2: A viagem do condenado como uma procissão}

Analisando as sete cartas de Inácio de Antioquia, Allen Brent ressaltou outra estratégia do autor: para sustentar a necessidade de manutenção da concórdia no interior das comunidades cristãs asiáticas (um tema que Brent acredita ser retirado da Segunda Sofística pelo antioqueno), o supervisor expõe sua condição não apenas com elementos reconhecíveis pelo cristianismo local, como o realce de seu caráter de mártir próximo, mas também da religião da pólis, ao retratar sua viagem como uma grande procissão que percorre o Mediterrâneo desde Antioquia até Roma, onde o autor deve ser oferecido em sacrifício em prol da unidade de todos os cristãos (BRENT, 2009: 45). De modo a fazer com que seus destinatários se sentissem contagiados e comovidos pelo espetáculo de sua viagem (e assim, consequentemente, com a agenda que defendia), o prisioneiro lançou mão de, basicamente, quatro ações.

Em primeiro lugar, movimentou um número dispendioso de pessoal, de modo que sua passagem não pudesse ser encarada como um simples transporte de um prisioneiro comum (SCHOEDEL, 1985: 12): mensageiros são enviados desde a Síria até Roma para comunicar a igreja da capital da chegada próxima de Inácio; um segundo mensageiro é enviado a Roma desde Esmirna, com a carta que conhecemos como In.Romanos; mensageiros são enviados às comunidades cristãos de Éfeso, Magnésia e Trália (talvez os mesmos enviados primeiramente a Roma), as quais enviam altos oficiais como seus representantes para encontrar Inácio em Esmirna, onde a caravana encarou algum atraso em sua viagem; a pedido do prisioneiro, um servidor da comunidade efésia, de nome Burro, permanece junto com ele durante a viagem, sustentado pelos fieis de Éfeso e Esmirna; Filo e Réo Agátopo, respectivamente da Cilícia e da Síria, seguem a trilha feita por Inácio até alcançá-lo em Trôade; e, por fim, Inácio pede o envio de representantes a Antioquia, no que parece ser atendido. Os custos de tamanha movimentação de gente 
podem ser imaginados quando temos em vista a incerteza do prisioneiro de que os efésios aceitarão manter Burro junto dele.

Em segundo lugar, Inácio utiliza suas cartas para representar eloquentemente a si mesmo como uma vítima a ser oferecida em sacrifício em Roma, de modo a que os benefícios divinos alcancem as igrejas asiáticas com a garantia de sua unidade interna (BRENT, 2009: 45-9). A representação é fundamentada na utilização de termos próprios ao culto religioso da pólis, em vista da concórdia pública: "Eu sou uma vítima expiatória $(\pi \varepsilon \rho i ́ \eta \mu \alpha)$ e me entrego como oferenda sacrifical ( $\dot{\gamma} v i \zeta \zeta o \mu \alpha)$ por vós, efésios, igreja

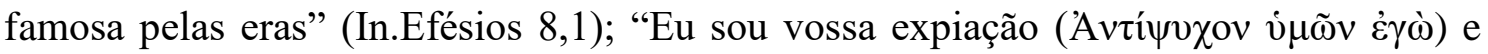
daqueles que enviastes para a honra de Deus a Esmirna, de onde vos escrevo..."

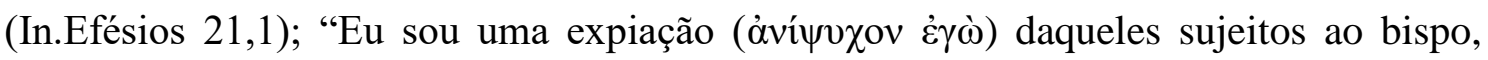
presbíteros e diáconos...” (In.Policarpo 6,1).

Em terceiro lugar, o antioqueno não apenas se representa como vítima sacrificial de uma procissão que percorre o Mediterrâneo, como faz de seus destinatários participantes do culto divino que, segundo ele, está acontecendo naquele exato instante em que eles estão ouvindo suas palavras, reunidos em assembleia (BRENT, 2009: 7194). A imagem por ele usada que talvez fosse mais impactante para os cristãos aos quais se dirigia é a dos portadores de imagens sagradas, muito comuns nos rituais públicos das pólis asiáticas: "E orai também por mim, que preciso de vosso amor na misericórdia de Deus, de modo a ser considerado digno da porção a qual devo conquistar, para que eu não seja rejeitado" (In.Tralianos 12,3); "Vós sois todos, portanto, co-membros de culto

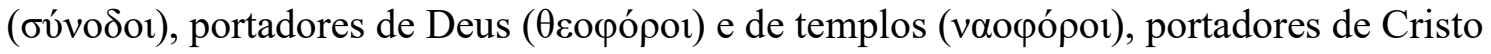

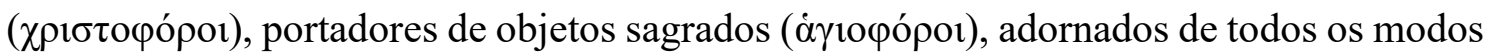
com os mandamentos de Jesus Cristo" (In.Efésios 9,2).

Em quarto e último lugar, para garantir que tudo o que fora dito tivesse chance de ter real efeito, Inácio dirige uma carta aos cristãos romanos para convencê-los a não buscarem salvá-lo de nenhum modo (como poderia fazê-lo não nos é sabido). Ou seja, implora para que deixem-no ser morto: "Eu vos exorto: não vos torneis uma bondade inoportuna para mim; deixai-me ser o alimento de feras selvagens, pelas quais posso alcançar Deus...” (In.Romanos 4,1). O seu próprio sacrifício seria a comprovação de sua tese: morrendo "pelo Nome" (In.Efésios 1,2) e "por aqueles que se sujeitam ao supervisor, aos anciãos e servidores" (In.Policarpo 6,1), Inácio fazia de si mesmo um mártir da causa da unidade da igreja como a enxergava, ou seja, com uniformidade ritual e doutrinal, 
inclusive (e, talvez, principalmente) em sua própria comunidade de origem, muito provavelmente atingida por divisões agressivas, como já referimos anteriormente ${ }^{139}$.

\subsubsection{3: Ataque aos docetistas}

\section{Um terceiro meio pelo qual Inácio instrumentaliza discursivamente sua condição} de prisioneiro rumando para a morte é na refutação apaixonada que faz das ideias dos docetistas $^{140}$. Com frases curtas e emocionadas, típicas da oratória asiática, o supervisor afirma ser incompatível a posição teológica de seus opositores com a situação por ele mesmo vivida:

Mas se, como alguns que são ateus - isto é, descrentes - dizem, que ele [Cristo] sofreu em aparência, enquanto eles que são mera aparência, por que eu estou em correntes? Por que eu peço até para lutar com as feras? Eu morro, portanto, em vão! Então eu estou mentindo sobre o Senhor! (In.Tralianos 10,1)

Uma vez mais, aparentemente, Inácio coloca como pressuposto que seus destinatários possuem uma consideração especial por aqueles que entregam a própria vida

\footnotetext{
${ }^{139}$ Moreschini e Norelli sintetizam bem a relação entre a morte buscada por Inácio e a pacificação da igreja de Antioquia: "After Ignatius's arrest, "Peace" returned; that is, his views won out. Against the background of the claims of aberrant groups and of conflicts within the church at Antioch, Ignatius's martyrdom was to prove beyond doubt the justice of his cause. It is probably for this reason that he also rejects any effort of the Roman church to save him" (MORESCHINI E NORELLI, 2005: 106).

${ }^{140}$ Nas palavras de César Vidal Manzanares, o docetismo seria uma "heresia de caráter gnóstico que no séc. I afirmava que a humanidade e os sofrimentos de Jesus na cruz foram somente aparentes" (MANZANARES, 2005: 129). No entanto, o docetismo muito provavelmente não constituiu uma espécie de escola teológica própria (como os valentinianos, por exemplo), sendo antes uma determinada característica cristológica difundida em vários grupos cristãos dos primeiros séculos. É possível que o autor da Primeira carta de João já enfrentasse cristãos com essa tendência de pensamento, ao afirmar categoricamente: "Nisto reconheceis o espírito de Deus: todo espírito que confessa que Jesus Cristo veio na carne é de Deus; e todo espírito que não confessa Jesus não é de Deus; é este o espírito do Anticristo" (4,2-3). Na visão de Raymond $\mathrm{E}$. Brown, contudo, ainda não seria uma visão teológica propriamente docética que estaria sendo atacada aqui, mas poderia ser uma forma ancestral da mesma de conceber a cristologia (BROWN, 1988: 107; cf. PERKINS, 2011: 828). O docetismo encontrava-se disperso em diversos textos depois considerados apócrifos, como o Evangelho de Pedro, conhecido pelo bispo Serapião de Antioquia (c. 200), que teria tomado conhecimento de sua leitura nas reuniões cristão em Rosso, no Noroeste da Síria (Eusébio de Cesareia, História Eclesiástica 6.12.2-6; cf. KOESTER, 2005: 177.215). Matti Myllykoski defendeu que Cerinto, tradicionalmente referido como o adversário principal do apóstolo João em Éfeso (Irineu de Lyon, Contra as heresias III.3.4), poderia ser a fonte principal das ideias docéticas que vieram a se desenvolver na Ásia (MYLLYKOSKI, 2008: 235-6). Devemos notar, porém, que o termo "docetista" não é nada mais e nada menos que um rótulo fundamentado teologicamente, com todos os problemas históricos a ele inerentes e à sua aplicação, inclusive por ser de uso posterior aos eventos estudados aqui. $\mathrm{O}$ uso, portanto, de tal termo na dissertação é devido simplesmente ao desejo de facilitar o desenvolvimento da narrativa, de modo a fazer referência a um grupo acusado por Inácio de Antioquia de defender que Cristo havia vindo ao mundo simplesmente em "aparência".
} 
(literalmente) pela fé. Deste modo, ele usa de sua condição para colocar os cristãos tralianos contra a parede: ou eles aceitam que Cristo não passou pelo mundo apenas em aparência, ou eles terão de renegar Inácio, uma vez que ele está desistindo de sua própria vida terrena por uma fé que considera inconciliável com aquela professada por seus opositores. Por trás dessas linhas, encontra-se também sugerido um argumento de autoridade: o prisioneiro que vai morrer confessando o nome e que vai, como visto no Apocalipse de João (possivelmente conhecido dos cristãos tralianos), "servir a Deus dia e noite em seu templo", afirma com todas as palavras que a doutrina de seus opositores é errônea. A ideia de Inácio aqui é, definitivamente, deixar pouca ou nenhuma margem para discordância.

\subsection{3: Inácio, o profeta}

Vimos, portanto, como Inácio ressalta continuamente sua prisão "pelo nome", aguardando que o resultado dessa longa viagem pelo Mediterrâneo, que ele caracteriza como uma grande procissão da qual as igrejas da Ásia Proconsular (ao menos aquelas com as quais se comunica) tomam parte ativa, resulte no sacrifício de sua vida em prol da unidade de todos os cristãos, sobretudo na submissão dos mesmos aos seus respectivos supervisores. No entanto, é significativo que o próprio prisioneiro praticamente não faça referência à sua própria posição de supervisor da igreja cristã que se encontra em Antioquia sobre o Orontes, certamente um centro cristão importantíssimo, tendo-se em vista sua função proeminente na difusão da nova seita. Uma das únicas exceções aqui pode ser encontrada em In.Romanos 2,2, onde ele faz referência a si mesmo como o “supervisor da Síria”. De fato, além de sua condição de sacrifício en route d'être, Inácio prefere sublinhar outra característica sua: o dom profético.

A autorrepresentação como alguém que possui acesso a conhecimentos ocultos e divinos e que recebe mensagens do Espírito Santo se sobrepõe patentemente, no discurso inaciano, à função de supervisor. O primeiro caso é sugerido em In.Efésios 20,1-2, onde, após fazer uma longa descrição das alterações cósmicas decorrentes da encarnação de Cristo (19), o autor diz: "Se Jesus Cristo me considerar digno pelas suas orações, e se for da vontade divina, vou dar-lhes um segundo livro... especialmente se o Senhor revelar algo para mim". No entanto, a questão é feita mais explícita na correspondência com os cristãos tralianos, com os quais Inácio crê precisar ser mais duro: 
Certamente não sou incapaz de vos escrever acerca das coisas celestiais? (...) Mesmo em meu caso, não porque eu esteja em correntes e seja capaz de conhecer as coisas celestes, tanto os locais angélicos quanto as formações arcônticas, coisas tanto visíveis quanto invisíveis... (In.Tralianos $5,1-2)$

O supervisor visa deixar claro a seus destinatários: se eles não fossem “crianças" (In.Tralianos 5,1), poderia escrever-lhes sobre as "coisas celestiais" às quais possui acesso, um conhecimento que, possivelmente (porém não necessariamente), advém de sua condição de mártir próximo. Mais uma vez, pouca margem é deixada para a contrargumentação.

Inácio, portanto, afirma ter acesso a conhecimentos ocultos, os quais seriam, em sua visão, provenientes de revelações da parte do "Senhor", provavelmente. Até aqui, existem poucos elementos que apontem para uma autocaracterização do autor com um profeta propriamente. Qualquer dúvida a respeito, porém, desaparece com um trecho fundamental da carta aos filadelfienses, ao qual já nos referimos anteriormente e que praticamente fala por si só, ao relatar um encontro entre Inácio e seus destinatários:

Pois embora alguns quisessem me enganar na carne, o Espírito, que é de Deus, não é enganado; pois ele sabe de onde vem e para onde vai, e expõe as coisas escondidas. Eu clamei quanto entre vós, eu falei com uma alta voza voz de Deus: "Estai junto ao supervisor, ao colégio dos anciãos e aos supervisores". Aqueles que suspeitaram que eu dizia tais coisas porque tinha informação anterior acerca da divisão de alguns - ele é minha testemunha, em quem estou acorrentado, que não o conheci de nenhuma criatura humana. Foi o Espírito que fez a proclamação, dizendo tais palavras: "Não façais nada sem o supervisor, mantende vossa carne como o templo de Deus. Amai a união, fugi das divisões. Sede imitadores de Jesus Cristo, como ele o é de seu Pai”. (In.Filadelfienses 7)

Durante um encontro com os cristãos filadelfienses, provavelmente quando da celebração de uma ceia sagrada (seja na própria cela, seja no próprio local de reunião dos cristãos locais, o que poderia pressupor uma visita anterior à prisão de Inácio), o supervisor afirma ter feito uma exortação inspirada pelo Espírito Santo, chamando os fieis locais a estarem em união com os oficiais da comunidade, em especial "não fazendo nada sem o seu supervisor". Vimos no capítulo 2 como tais exortações que se diziam inspiradas 
eram comuns nas comunidades da Ásia, o que é confirmado tanto pelas cartas de Paulo quanto pelo Apocalipse de João. A defesa do caráter inspirado da mensagem proferida, em conjunto com a ambientação explicitada e a defesa de um conhecimento oculto nos trechos citados acima, deixa pouco espaço para dúvida: Inácio considera-se profeta e, no momento de tensão, é como profeta que espera ser ouvido, e não como o supervisor da igreja de Antioquia. Sua exortação profética também é clara: os cristãos "não devem fazer nada sem o seu supervisor", em vista do "amor à unidade".

\section{4: Um passo adiante para a autoridade do supervisor}

Inácio de Antioquia fez de tudo para que aquela que acreditava ser sua última viagem (se pudermos dizer que havia feito outras, o que não pode ser afirmado com certeza) fosse também um grande evento mediterrânico (SCHOEDEL, 1985:12): enviou mensageiros às comunidades cristãs na província da Ásia e também a Roma; ditou quantas cartas pôde (Romanos 4,1; Policarpo 8,1), chamando a atenção de seus destinatários para que obedecessem ao seu supervisor, assim como aos anciãos e servidores que os presidiam; tratou sua morte como um grande ritual envolvendo todas as igrejas cristãs, um sacrifício em prol de todos aqueles que comungavam de seu pensamento com respeito à unidade comunal (BRENT, 2009: 94; cf. Policarpo 6,1). Morrendo na arena romana, o antioqueno esperava que seu clamor em favor da autoridade do supervisor único fosse atendido por todos aqueles aos quais escreveu. Com a cópia e difusão das cartas de Inácio de Antioquia, não eram apenas as últimas palavras de um mártir próximo que se faziam conhecer, mas também a defesa contundente e apaixonada (porém não menos racionalizada) de um modelo de organização da comunidade no qual a figura do supervisor único é colocada em posição proeminente. Semelhante defesa encontra-se em praticamente todas as suas cartas, excetuando unicamente a dirigida aos cristãos romanos.

A seção final da dissertação visa investigar os meios utilizados por Inácio para realçar a posição do supervisor, não agindo apenas de forma unilateral ao impor uma forma de liderança não existente anteriormente por meio de sua retórica e autoridade própria de profeta condenado pela fé, mas dialogando com uma forma de organização comunal já conhecida de seus destinatários. No discurso inaciano, porém, o que já é conhecido pelos cristãos é significativamente incrementado, quando, de mero correspondente analógico a um chefe de óikos, o supervisor é alçado a representação do 
próprio Deus Pai no âmbito da vivência comunitária, especialmente no espaço ritual. As intenções aqui, porém, não param simplesmente no âmbito do simbólico, uma vez que visam desdobramentos bem práticos nas ferramentas de controle social à disposição do supervisor.

\subsection{1: O supervisor e Deus Pai}

A representação de Deus como um pai tinha um lugar central no ideário cristão do primeiro século de existência do cristianismo, como muitos trechos dos evangelhos deixam explícito: o caráter paterno e patriarcal da divindade em suas relações com seus adoradores dava aos últimos a liberdade de dirigir-se a ele como sendo seu pai, podendo pedir-lhe o que fosse de sua necessidade sem qualquer temor. Nas igrejas paulinas, a paternidade de Deus, ao que parece, possuía um papel fundamental na ritualística, uma vez que, ao que parece, a pessoa batizada era instada, após ser mergulhada na água, a clamar “Abba, Pai', demonstrando ao resto da comunidade que agora o Espírito Santo o fizera ser adotado pela divindade. Deste modo, a afirmação de que Deus era pai de todos aqueles batizados em nome de Cristo encontrava-se no centro daquela ressocialização à qual nos referimos no capítulo 2, na seção sobre o ritual nas igrejas paulinas (e, no caso do nosso estudo, asiáticas): se novos laços sociais eram criados entre os membros de uma comunidade local, era porque todos eles possuíam um pai divino comum.

Uma das principais características das cartas de Inácio de Antioquia é a insistência em referir-se a Deus como sendo pai (45 vezes em todo o epistolário), fazendo-o especialmente em sentenças nas quais faz referência a Jesus Cristo, a quem também considera como sendo divino $^{141}$ (SCHOEDEL, 1985: 18). No entanto, Deus não é apenas pai. Para Inácio, ele é, também, supervisor de todos os cristãos, perpetuamente exercendo o trabalho de liderança e administração de sua comunidade de fieis. A profundidade e importância de tal caracterização da divindade torna-se evidente quando ele a ressalta a uma igreja como a dos romanos, por exemplo, em uma carta que, excepcionalmente, não entra em qual quer discussão a respeito da importância do supervisor cristão: "Lembrai-

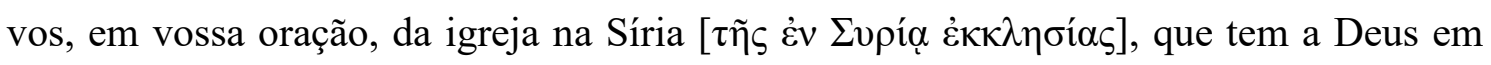

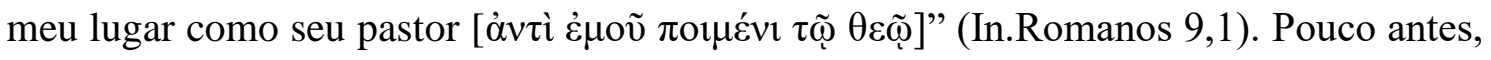
Inácio ressaltara (o que é raro em suas cartas) seu caráter de "supervisor da Síria” [ $\tau$ òv

\footnotetext{
141 "Inácio... àquela... unida e eleita em sofrimento verdadeiro, pela vontade do Pai e de Jesus Cristo, nosso

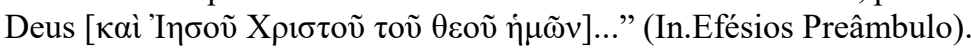




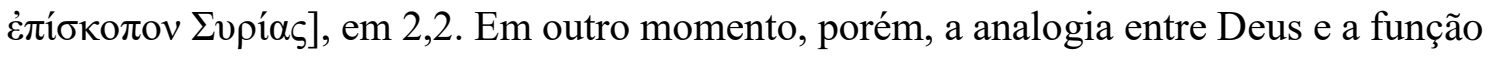
do supervisor é feita mais patente pelo antioqueno; ocorre que, ao escrever aos cristãos magnésios, Inácio reclama do fato de algumas pessoas insistirem em se reunir sem a presença do supervisor da igreja da cidade:

Assim, para a honra daquele que nos quis, é correto obedecer sem

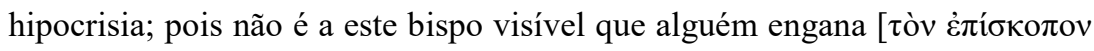

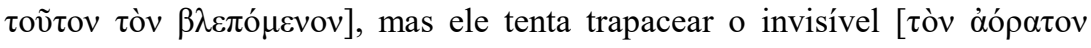
$\pi \alpha \rho \alpha \lambda o \gamma i ́ \zeta \varepsilon \tau \alpha 1]$. Neste caso, não é à carne que se deve prestar contas, mas a Deus, que conhece nossos segredos. (In.Magnésios 3,2)

Não adianta de nada aos "resistentes" tentar enganar ao seu supervisor, mantendo encontros e reuniões autônomos, pois aquele a quem se tenta enganar é o único supervisor que não pode ser enganado, Deus. Um aliado todo-poderoso tem, portanto, o supervisor cristão na figura daquele que exerce a mesma função que ele, mas com relação a todos, como diz o mesmo Inácio um pouco antes: “....assim como eu sei que vossos santos anciãos também não presumiram de sua aparente juventude [de Damas, supervisor dos cristãos de Magnésia] mas, como homens sábios em Deus, se submetem a ele - de fato,

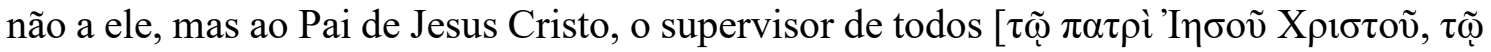

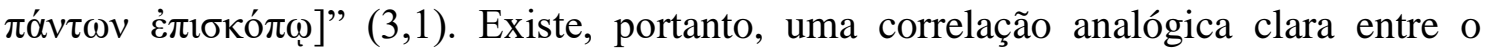
"supervisor na carne" (In.Efésios 1,3) e aquele invisível, mas sempre vigilante, que é também, como já dito, supervisor inclusive de seu correspondente terreno, o que é deixado claro por Inácio no preâmbulo de sua carta dirigida a Policarpo de Esmirna, com o acréscimo da figura do próprio Jesus Cristo: "Inácio, também chamado 'portador de

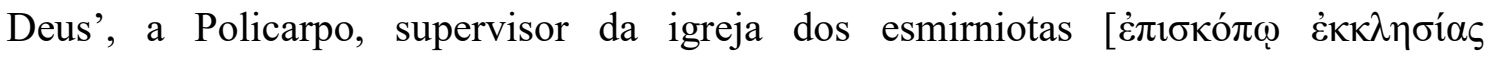
$\Sigma \mu v \rho v \alpha i ́ \omega v]$, ou, ao invés, alguém que tem Deus Pai e o Senhor Jesus Cristo como

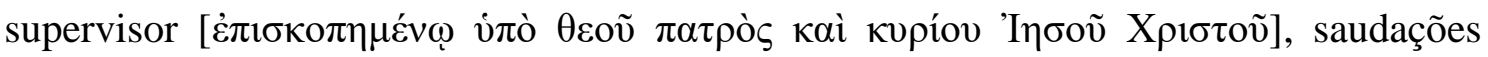
abundantes" (Trad.: EHRMAN, 2003: 311; SCHOEDEL, 1985: 257).

No entanto, se por um lado uma correlação analógica é feita entre Deus Pai e o supervisor cristãos, de modo a como que apontar uma característica da relação entre a divindade e seus adoradores a partir de um ponto de partida visível do cotidiano dos discípulos asiáticos de Cristo, também o caminho inverso é executado por Inácio de Antioquia, com a designação do supervisor como sendo uma espécie de representação do próprio Deus Pai nas reuniões. Esse ponto pode ser ressaltado da exortação que faz o 
prisioneiro a seus destinatários de Magnésia: “...animai-vos a fazer todas as coisas na concórdia de Deus [ $\varepsilon \dot{\varepsilon} v$ ómovoíą $\theta \varepsilon o v ̃]$, com o supervisor estabelecido sobre vós no lugar

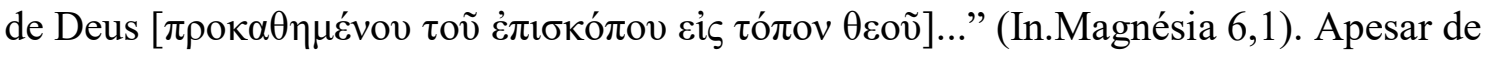
aqui Inácio referir-se ao supervisor como estando simplesmente "estabelecido no lugar de Deus", presume-se que esse último seja o mesmo "Pai" divino abordado diversas vezes antes e depois, tanto na referida carta quanto em todas as outras, uma vez que Jesus Cristo é colocado especificamente relacionado, logo após, aos servidores da comunidade.

Tal leitura é confirmada em pelo menos dois outros pontos das cartas. Em primeiro lugar, ainda em In.Magnésios, já ao final do documento, com as despedidas devidas e formuladas com toques especiais do estilo inaciano, a obediência que todos os cristãos devem ter a seu supervisor (e também uns pelos outros, embora aquela devida ao supervisor venha colocada em primeiro lugar) recebe um referencial de peso: "Sede submissos [نं

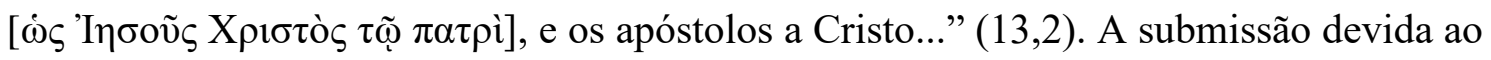
supervisor e, conjuntamente, uns aos outros, é comparada com aquela de caráter filial entre o próprio Jesus com seu pai divino e os apóstolos com seu mestre, também divino.

O segundo ponto, mais explícito e direto, encontra-se em outra carta, aquela dirigida aos cristãos tralianos. Aqui existe uma espécie de junção entre os princípios dos dois trechos citados anteriormente, uma vez que divide as representações específicas de cada conjunto hierárquico da comunidade, como no primeiro caso, mas não o fazendo exatamente no âmbito específico da reunião ritual e sim no da convivência cotidiana, como parece ser pressuposto pelo segundo: "Do mesmo modo, que todos respeitem aos

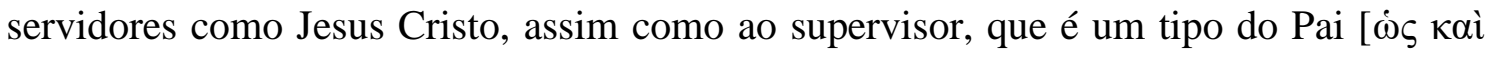

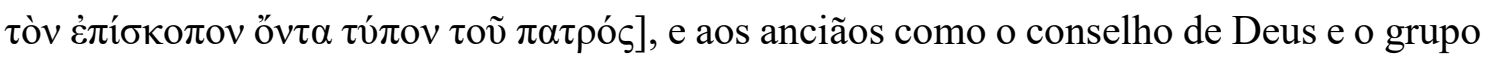
dos apóstolos" (In.Tralianos 3,1).

Outros casos de ligação mais implícita entre a figura do supervisor e a de Deus Pai podem ser identificados, como naquele em que Inácio exorta os anciãos cristãos tralianos a "auxiliar o supervisor para a honra do Pai de Jesus Cristo e dos apóstolos [Eiৎ

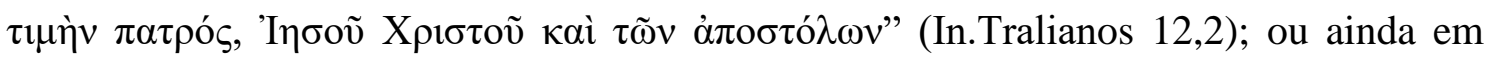
outro, onde ele exorta seus destinatários dizendo que eles devem "todos seguir o

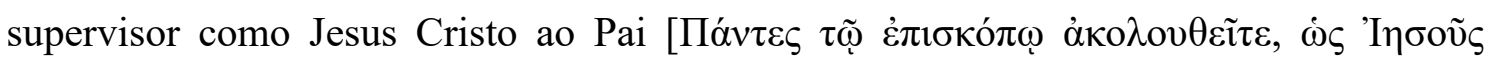

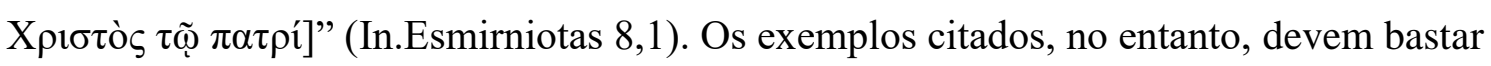
para termos em mente uma tendência inaciana de revestir o supervisor da igreja da figura patriarcal do Deus Pai cristão, chamando seus destinatários a terem por ele um respeito 
filial, não um imperfeito como eles mesmos possam ter pela divindade, mas tão próximo quanto possível daquele modelo oferecido pelo próprio Jesus.

\subsection{2: O supervisor pai}

A partir de tal representação do supervisor da parte de Inácio, e de sua admoestação para a relação ideal entre os cristãos locais com o mesmo, devemos nos perguntar até que ponto ele está trazendo para seus destinatários uma tese nova que, talvez, esteja buscando afirmar simplesmente com sua autoridade arrogada de “acorrentado em Cristo" e profeta. Certamente que Inácio pode lançar mão de tal argumento de autoridade a qualquer momento que considerar conveniente a fim de reforçar sua exortação. No entanto, devemos ter em conta que os momentos em que ele o faz de forma mais contundente são justamente aqueles presentes em In.Tralianos e In.Filadelfienses, no primeiro caso uma comunidade que, ao que tudo indica, era de recente fundação, e no segundo caso uma igreja fortemente marcada por (aquilo que Inácio considera) divisões internas. Nas outras cartas, o prisioneiro não vê necessidade de reforçar seu ponto de vista recorrendo à sua condição ou a qualquer dom profético.

Devemos, portanto, considerar a possibilidade de que, ao menos em algumas das igrejas endereçadas, o supervisor já era valorizado de forma especial, ainda que talvez não tanto quanto Inácio esperava delas. Neste caso, o autor poderia estar estabelecendo um diálogo com aquilo que já era parte da convivência entre os cristãos locais, ao mesmo tempo que defendendo um passo além do que já por eles experimentado. O primeiro passo para uma tal leitura é retornar ao que se encontra dito no capítulo 2 acerca do conteúdo de 1Timóteo, que argumentamos provavelmente representar um ponto de vista ou tendência existente na Ásia pelo fim do século I d.C., provavelmente em Éfeso, de forma mais específica.

Vimos que 1Timóteo inicia sua tratativa acerca dos ofícios próprios de uma igreja urbana específica com o cargo de supervisor, elencando uma série de requisitos que um candidato deve cumprir para que possa ocupar a função. Uma delas é destacada de forma especial pelo autor: o supervisor deve, necessariamente, ser um homem que saiba governar bem sua casa. O requisito não é surpreendente, em princípio; uma vez que um supervisor deveria exercer uma função deveras visível a todos os membros de sua comunidade, não é de se estranhar que fosse esperado dele (tanto pelo autor quanto, muito provavelmente, pelos próprios fieis) uma qualidade mínima em administração, e a forma 
de governo de uma casa poderia perfeitamente ser uma vitrine. No entanto, o autor parece não estar levando tanto em conta uma gestão econômica da parte do supervisor. Ao invés, logo após citar o dito requisito, ele complementa-o com a consideração de que o candidato deve ter a capacidade de "manter os filhos em submissão". Afinal, e sempre nas palavras do autor, "se alguém não sabe governar bem a própria casa, como cuidará da igreja de Deus"? Podemos notar, portanto, que o governo ao qual o autor se refere é, especialmente, um de caráter pessoal: a igreja deve ter à sua frente, como supervisor, alguém que saiba agir nela de forma semelhante a como age em sua casa. Se os filhos são displicentes, brigados entre si e tendentes à divisão do ambiente doméstico, seu pai, notoriamente, não se mostrará apto a garantir que o mesmo não ocorra entre os membros da comunidade. $\mathrm{O}$ autor destaca, portanto, a necessidade de o supervisor a ser eleito ser um bom pai, de modo que possa exercer um papel análogo (embora não exatamente semelhante, uma vez que ele nunca explicita a exigência de uma relação filial entre os fieis e o supervisor) em sua igreja, seguindo as normas tradicionais das pólis da boa condução da household e das qualidades necessárias a um homem para que seja um bom administrador da mesma ${ }^{142}$.

Contudo, 1Timóteo representa, em princípio, a visão de seu autor; não temos dados para considerar, a partir da carta fictícia, que seus leitores pensariam o mesmo. Podemos mesmo ressaltar que os Atos dos Apóstolos não fazem qualquer referência a uma tal exigência dos anciãos aos quais se refere como supervisores. Devemos, por outro lado, buscar saber se as próprias cartas inacianas possuem evidências de que o supervisor fosse (ou não) considerado da mesma forma pelos destinatários, cristãos asiáticos. Alguns dados podem ser ressaltados neste sentido.

\subsubsection{1: O supervisor em destaque}

Em primeiro lugar, podemos ressaltar que algumas das comunidades endereçadas por Inácio poderiam, ao menos em parte, considerar o supervisor de forma especial, enquanto em outras, tal possibilidade aparentemente sequer é vislumbrada. Em pelo menos uma das igrejas endereçadas por Inácio essa realidade é explícita. Escrevendo aos

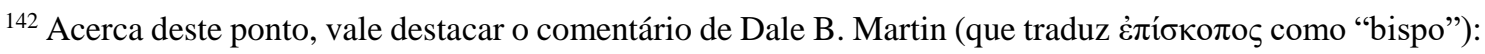
"This is all very traditional morality of Greek and Roman culture, with its emphasis on the traditional, patriarcal household. (...) The bishop occupies the role in the church that the paterfamilias does in a conservative Roman family. And all the traits here mentioned could have been read out of almost any middle-of-the-road philosophical treatise on morality and household management. The social model is all completely conservative and traditional" (B. MARTIN, 2012: 287).
} 
cristãos magnésios, em determinado momento o antioqueno utiliza um argumento difícil de se refutar contra aqueles que poderiam abusar da juventude do bispo magnésio:

E vós não deveis tomar vantagem da juventude de vosso supervisor, mas mostrar-lhe todo o respeito de acordo com o poder de Deus Pai, assim como sei que vossos santos anciãos também não presumiram de sua aparente juventude, mas, como homens sábios em Deus, submetem-se a ele

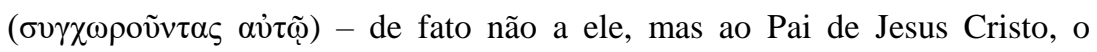
supervisor de todos. $(3,1)$

Inácio afirma que os anciãos cristãos de Magnésia se submetem ao seu supervisor, mesmo ele sendo mais jovem do que o costumeiro ${ }^{143}$. Embora um testemunho direto da submissão de anciãos ao supervisor seja uma particularidade da carta aos magnésios (muito provavelmente pela excepcionalidade do caso, envolvendo a demasiada juventude de um supervisor), a precedência honorífica do cargo frente ao dos anciãos pode ser identificada também em Éfeso, para cuja igreja Inácio afirma que “vosso bem-reputado

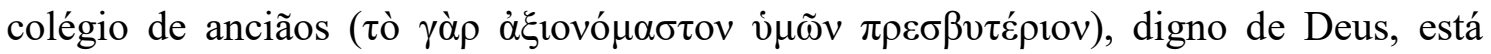
afinado com o supervisor como cordas com uma cítara" (Efésios 4,1). Embora a caravana efésia não contasse com anciãos, o fato de Inácio utilizá-los como exemplo para os seus leitores/ouvintes (ou seja, não visando exortar aos próprios anciãos) sugere a plausibilidade da informação: provavelmente os "anciãos" da igreja de Éfeso estavam buscando permanecer "afinados" com seu supervisor, o que pode se referir à comunhão na teologia, à aceitação da condução comunitária por Onésimo e/ou ao apoio ao mesmo em seus momentos de inabilidade comunicativa (cf. Efésios 6,1). Também em Filadélfia provavelmente ocorria o mesmo: em nenhum momento Inácio parece fazer uma justificativa inovadora da precedência do supervisor com relação aos anciãos da igreja, mas, ao invés, considera verdadeiramente pressuposto que a função principal dos últimos é assistir ao primeiro de forma permanente. Assim, ao falar daqueles que causavam divisões na comunidade (possivelmente por não aceitarem a concentração de poder na administração tripartida, defendida por Inácio; cf. Filadelfienses 6,3-8,1), o antioqueno

\footnotetext{
${ }^{143}$ Poderia ser argumentado que o antioqueno utiliza-se aqui daquele artifício retórico identificado anteriormente, no qual ele coloca o objeto de sua exortação como uma realidade premente. No entanto, esse não parece ser o caso aqui. É necessário recordar que, diferente do caso dos visitantes efésios e tralianos, a caravana magnésia contava com dois anciãos, Basso e Apolônio, que muito provavelmente estavam junto de Inácio quando da escrita da carta. Também seriam os mesmos anciãos corresponsáveis por conduzir o documento inaciano ao seu destino. Seria difícil conceber aqui que Basso e Apolônio aceitariam facilmente levar um documento de volta à sua igreja rebaixando-os na escala de poder comunitário se eles já não ocupassem uma posição não equânime à do supervisor.
} 
os exorta da seguinte forma: "Todos, portanto, que se arrependem, o Senhor os perdoa, se eles voltarem arrependidos para a unidade de Deus e o conselho do supervisor

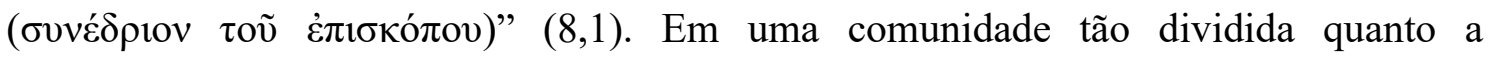
filadelfiense, seria de se esperar que Inácio abordasse de forma sutil e não tão direta as responsabilidades do conselho de anciãos para com o supervisor da igreja (sutileza que ele demonstra em toda a carta ao abordar as ditas divisões). Não é isso o que ocorre aqui. $\mathrm{Na}$ verdade, o prisioneiro sequer aborda o tema em si, mas considera de conhecimento comum, sem a necessidade do artifício retórico identificado anteriormente, que os anciãos constituem o conselho do supervisor cristão de Filadélfia, e que, aparentemente, nenhum dos membros desse colégio encontra-se comprometido com os cismáticos. Inácio considera os cismáticos e os anciãos como grupos completamente opostos e não faz qualquer esforço para justificar seu ponto de vista. Ele é pressuposto na comunicação.

Desta forma, em pelo menos três igrejas às quais Inácio se dirige, o ocupante do cargo de supervisão possivelmente guardaria certa precedência frente aos anciãos, sendo que em um caso (o de Magnésia) ela é mais acentuada. O mesmo pode ser dito relativo aos seus servidores. Por outro lado, nas igrejas de Trália e Esmirna essa precedência parece não ser tão universalmente aceita, ao menos em parte. Aos tralianos, Inácio dirigese na parte final da carta nos seguintes termos:

Minhas correntes vos exortam, as quais carrego por causa de Jesus Cristo, com a oração de que eu possa obter Deus; perseverai em vossa

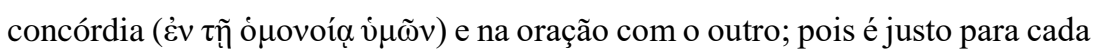
um de vós, mas especialmente aos anciãos, reanimar ao supervisor para a honra do Pai de Jesus Cristo e dos apóstolos. Eu rogo que me ouçais no amor, para que eu não venha a ser testemunha contra vós por ter escrito. (12,2-3)

Esse é um trecho singular nas cartas de Inácio. É o único em que ele faz uma ameaça (ainda que caridosamente disfarçada) direta aos seus destinatários, caso não aceitem sua exortação; e, ainda mais surpreendente, os anciãos tralianos também são ameaçados. De fato, a igreja de Trália é a única que envia apenas o seu supervisor ao encontro do antioqueno em Esmirna. Deste modo, Inácio vê-se na necessidade de exortar também a eles. No entanto, como já visto acima, o escritor não se dirige nos mesmos termos aos anciãos de Éfeso, do qual também não recebe representantes em sua cela; pelo

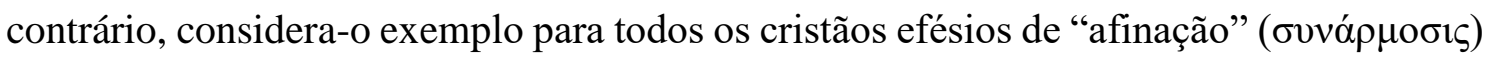
com o supervisor (cf. In.Efésios 4,1). Por outro lado, o fato de Inácio dizer que o ato de 
reanimar o supervisor serve para a honra não só de Deus, como dos apóstolos também, indica uma exortação direta aos anciãos que, no pensamento do antioqueno, representavam aos mesmos na vida da comunidade. Considerando que o próprio Inácio afirma ser o supervisor, Políbio, sua única fonte de informação $(1,1)$ acerca da igreja de Trália (diferente do caso de Filadélfia, no qual o Espírito Santo também desempenha um papel), pode ser afirmada a forte possibilidade de que os relatos recebidos pelo antioqueno acerca dos anciãos tralianos não deveriam ter sido muito positivos. Os anciãos não estavam dando o apoio considerado conveniente por Inácio a Políbio, especialmente em um contexto de divisões doutrinais em uma comunidade de fundação recente.

A mesma falta de apoio talvez estivesse ocorrendo em Esmirna. Em determinado momento da carta de Inácio aos cristãos esmirniotas, ao fazer uma grande crítica àqueles que seguiam a visão teológica de que Cristo havia passado pela terra apenas em aparência, ele fala aos seus destinatários nos seguintes termos:

Que ninguém se engane: mesmo os poderes celestes, a glória dos anjos e as autoridades, tanto as visíveis quanto as invisíveis, se elas não acreditarem no sangue de Cristo, estão também sujeitas a julgamento. O que puder entender, entenda. Que a posição não infle a ninguém ( $\tau$ o $\pi \circ \varsigma \mu \eta \delta \varepsilon v \alpha$

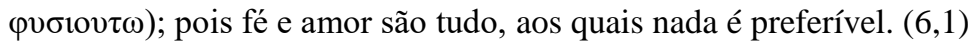

Esse é o único momento em todas as suas sete cartas que Inácio discute a inutilidade da "posição" ( ele deixa transparecer a existência de ao menos uma pessoa de "posição" entre aqueles que acusa de não acreditar "no sangue de Cristo", isto é, na realidade física de sua encarnação, morte e ressurreição. Seja quem fosse tal pessoa (se ela era apenas uma), o antioqueno provavelmente a conheceu, como deixa transparecer na mesma parte da mesma carta ${ }^{144}$. Também em Esmirna, portanto, apresenta-se um caso provável de resistência, talvez por parte de um ancião ou mais de um, contra Policarpo. Talvez não

\footnotetext{
${ }^{144}$ Nela, ele questiona os defensores do docetismo: "Pois que benefício alguém me dará, louvando-me, mas blasfemando o meu Senhor, não confessando que ele é portador de carne?" $(5,2)$ Inácio conhece mesmo o nome daqueles aos quais acusa: "Seus nomes, que são infiéis, não me pareceu bem escrever; de fato, não pretendo sequer lembrar-me deles..." $(5,3)$. Que posição teria essa pessoa na comunidade? O fato de ele usar o exemplo de "poderes celestes", "anjos" e "autoridades" inviabiliza a possibilidade de ele referir-se a

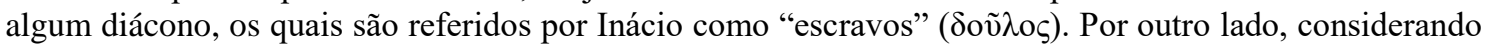
que Inácio pressupõe em sua carta o reconhecimento de um único supervisor na comunidade, e que, no presente trecho, ele ignora completamente o seu argumento comum da necessidade de se reunir com um único supervisor no único altar (cf. Filadelfienses 4), torna-se bem improvável a conjectura de que poderia existir um bispo rival de Policarpo na igreja de Esmirna, como defendeu Walter Bauer (BAUER, 2009: 98).
} 
fosse sequer uma sedição, ou seja, uma revolta de membros comunitários hierarquicamente inferiores contra seu superior; o mais provável é que não houvesse qualquer gradação de autoridade em Esmirna entre o supervisor e os anciãos (TREBILCO, 2004: 666).

\subsubsection{2: O supervisor como administrador}

Um segundo ponto que cremos poder ser resgatado das cartas inacianas é a confirmação de que, ao menos em algumas igrejas endereçadas por Inácio de Antioquia, o supervisor poderia estar encarregado da administração das finanças comunitárias.

Em todas as sete cartas inacianas, os únicos momentos nos quais o antioqueno faz uma referência clara a uma função do supervisor de guarda e redistribuição de bens se encontram em sua carta pessoal dirigida a Policarpo de Esmirna. Nessa carta, Inácio oferece uma série de conselhos a Policarpo sobre como guiar a igreja à qual fora designado supervisor. Dentre esses conselhos, dois devem ser destacados: no primeiro,

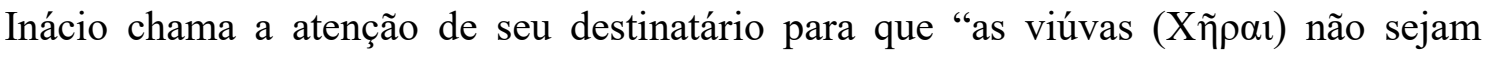

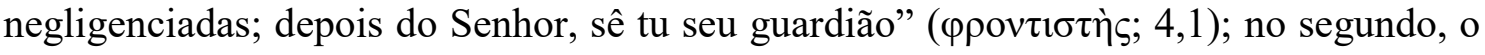
antioqueno exorta a que os escravos não sejam desprezados, mas ao mesmo tempo adverte Policarpo a atentar a que os escravos "não desejem ser libertados pelo fundo comum (ảjò

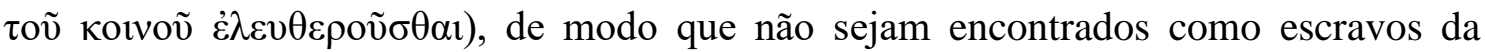

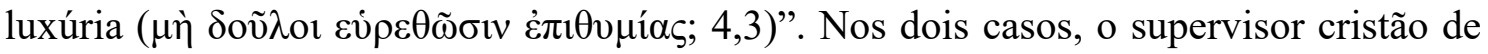
Esmirna é instruído a respeito de como agir com relação a cristãos de sua igreja em situações socialmente frágeis de vida. As viúvas, especialmente aquelas sem filhos, poderiam se encontrar em situação de indigência. Deste modo, o fundo comunitário poderia ser usado para dar-lhes o mínimo para sua subsistência. O fato de Inácio exortar Policarpo a não abandonar sua responsabilidade como "guardião" das viúvas cristãs sugere que ele tivesse algum encargo sobre o dinheiro comum, citado logo a seguir no caso dos escravos. Nesse último caso, as recomendações do antioqueno são mais duras. Ele parece conhecer casos (de Esmirna e/ou de Antioquia) de escravos cristãos que estavam se colocando na mesma posição de outros indigentes, de modo a ter sua liberdade comprada pela comunidade. Inácio rejeita tal iniciativa e alerta Policarpo contra ela, considerando que para o escravo o melhor é que permaneça como tal, no mínimo não utilizando o dinheiro comum da igreja para conseguir uma condição de vida a qual, pela falta de um controle severo externo, poderia conduzi-lo aos vícios comuns à liberdade. 
De qualquer forma, o mais interessante no texto para este estudo é o pressuposto de que Policarpo possua algum controle sobre o fundo comum que lhe permita negar a algum cristão de sua comunidade a utilização do mesmo para fins duvidosos.

No entanto, outros trechos das cartas indicam que, embora o supervisor pudesse ter a prerrogativa de reger os gastos ordinários da igreja a partir do fundo comum (como no caso do auxílio às viúvas), por outro lado existia limites para sua autonomia neste campo. Existiam gastos de caráter extraordinário que exigiam a aprovação de toda a comunidade. O exemplo que temos dessa limitação vem da carta de Inácio aos efésios. Logo ao início da carta, o antioqueno está nomeando os membros da igreja de Éfeso que foram ter com ele na prisão em Esmirna. Um deles é um servidor chamado Burro, o qual Inácio pede que permaneça com ele; essa permanência, contudo, certamente traria custos consigo. O interessante, porém, é que ele faz esse pedido por carta estando o supervisor efésio, Onésimo, presente em Esmirna. Ao mesmo tempo, Inácio é cauteloso ao fazer esse pedido: outro membro eminente da igreja efésia, Croco, já lhe havia "aliviado em tudo"

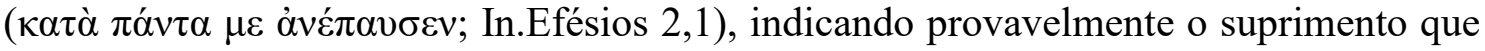
em uma situação de aprisionamento seria naturalmente insuficiente. Ao pedir que, além de tudo isso, os efésios sustentem também a viagem de Burro a serviço do prisioneiro, esse último escreve: "Que eu possa sempre me beneficiar de vós, se eu for digno"

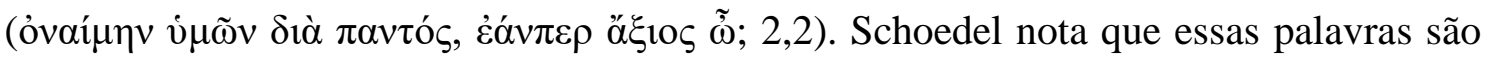
uma variante de uma expressão popular utilizada na comunicação antiga em momentos de incerteza, delicadeza ou pior (SCHOEDEL, 1985: 45). Inácio está requisitando aos fiéis efésios, e não a Onésimo, que se disponham a arcar com um gasto a mais, se considerarem o antioqueno digno de tal graça. Tudo isso sugere que, pelo menos na comunidade de Éfeso, o supervisor não possui poder ilimitado sobre o fundo comum; ao menos os gastos extraordinários e imprevistos precisam da aprovação dos cristãos efésios em conjunto.

Não é possível se afirmar com certeza se o que foi visto a respeito de Esmirna vale para Éfeso e as outras igrejas da Ásia e vice-versa. Se pudermos, contudo, considerar que existe um padrão discernível nas cartas inacianas de direção financeira nas comunidades da Ásia, o modelo se apresentaria mais ou menos da seguinte forma: o supervisor seria o responsável primeiro pela administração de um fundo comum que pertence à comunidade como um todo e cabe a ele reger os gastos ordinários, como as obras de caridade e o sustento de membros em contextos sociais frágeis ou mesmo em situações de indigência; contudo, na eventualidade de se haver uma necessidade ou requerimento de gastos 
extraordinários, a comunidade como um todo deve ser ouvida, de modo que não poderia o supervisor tomar uma decisão independente da opinião dos outros fieis.

\subsubsection{3: O passo além de Inácio}

Vemos, portanto, que, muito provavelmente, em alguns casos de igrejas asiáticas, o supervisor encontrava-se de fato à frente do governo de um conjunto de fieis, o que não significa necessariamente que todos os grupos cristãos estivessem dispostos a seguir alguém executando tal função. No entanto, mesmo onde o supervisor tivesse sua posição relativamente consolidada, teríamos aí uma caracterização do mesmo como uma figura patriarcal, fazendo às vezes de pai do agrupamento local de cristãos? A quantidade formidável de resistências em todas as cartas dirigidas aos cristãos asiáticos parece sugerir-nos uma resposta negativa: mesmo que alguns cristãos tivessem em mente a equiparação analógica entre o governo da casa e o governo da igreja, conforme encontrado em 1Timóteo (o que não é certo), os supervisores, em geral, não se encontravam estabelecidos de forma sólida o suficiente frente aos fieis em geral, de modo que pudessem ser vistos como uma figura paterna ${ }^{145}$. Se o supervisor fosse um dos responsáveis por receber os cristãos em sua casa para a realização da ceia sagrada, o que é possível se tivermos em vista a "hospitalidade" requerida por 1Timóteo aos candidatos à função, poderíamos conjecturar que muito do respeito devido a ele se desse por uma relação do tipo patrono-cliente. No entanto, como não temos maior embasamento documental para afirmar algo do tipo, o melhor é que nos calemos por aqui a esse respeito.

Interessa-nos agora, por outro lado, realçar a resposta de Inácio de Antioquia a tal situação. Ele claramente não se encontra satisfeito com o que encontra, seja pessoalmente (como se deu, muito provavelmente, em Esmirna), seja pelo relato das delegações a ele enviadas, todas elas contando com o supervisor à sua frente. Inácio, como visto anteriormente, vincula o supervisor à figura de Deus Pai; em outras palavras, ele visa patriarcalizar a função de supervisão. Neste ponto, ele não se prende à mera figuração

\footnotetext{
${ }^{145}$ Este ponto contradiz um dos principais argumentos de Joly contra a autoria das cartas por Inácio de Antioquia: "Les Lettres sont d'une part un plaidoyer on ne peut plus insistant pour l'autorité de l'évêque, mais d'autre part, elles témoignent que cette hiérarchie cléricale est pleinement acquise, comme un fait qui va de soi dans les communautés auxquelles Ignace s'adresse" (JOLY, 1979 : 75). É como se o próprio Joly tivesse sido convencido pela retórica de Inácio: de certo, seria difícil imaginar nessa época todos os cristãos de uma mesma cidade aceitando pacificamente uma autoridade centralizadora como o seria o supervisor idealizado pelo autor.
} 
retórica, partindo, ao invés, para exortações práticas tanto aos fieis como ao próprio supervisor, todas elas apontando para o mesmo sentido.

No caso de suas exortações aos fieis, o foco de Inácio é na necessidade, para a boa e divina ordem, de os cristãos se submeterem ao seu supervisor, o que nos faz lembrar do que diz o autor de 1Timóteo quanto à necessidade de um bom governante de uma casa saber manter seus filhos em submissão. Já vimos, mais acima, o caso da carta aos magnésios, onde Inácio usa o exemplo dos próprios anciãos que "se submetem" ( $\sigma v \gamma \chi \omega \rho o \tilde{v} \tau \alpha \varsigma \alpha$ $\alpha \tilde{\omega})$ a Damas, o supervisor local, de modo a requerer do resto dos cristãos a mesma atitude (In.Magnésios 3,1). Outros exemplos, porém, podem ser citados, por vezes arrolando outras lideranças do grupo:

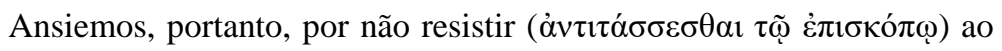

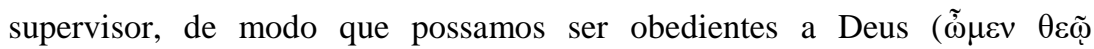

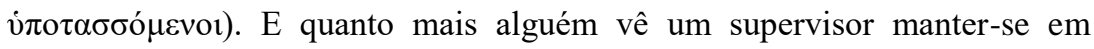
silêncio, mais deveria ele temê-lo ( $\alpha$ $\tau o ̀ v ~ \varphi o ß \varepsilon i ́ \sigma \theta \omega)$. (In.Efésios 5,3-6,1)

Pois quando vós sois submissos ao supervisor como a Jesus Cristo $(\tau \tilde{\varphi}$

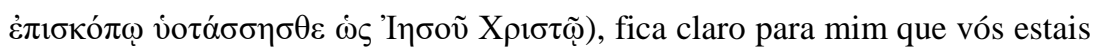
vivendo não à maneira humana, mas à maneira de Jesus Cristo, que morreu por nós, de modo que, acreditando em sua morte, vós possais escapar de morrer. (In.Tralianos 2,1)

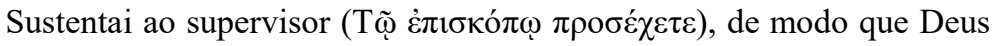
também possa atender-vos. Eu sou uma expiação daqueles sujeitos ao

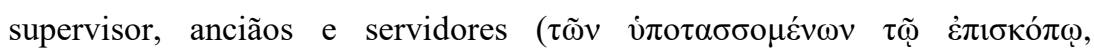

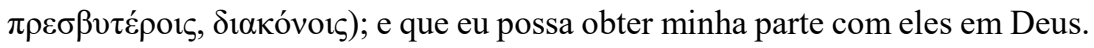
(In.Policarpo 6,1)

As cartas inacianas deixam patente uma recorrência de seu autor à defesa da submissão dos fieis ao supervisor, de modo a manter a unidade do corpo da comunidade. Se existe um único supervisor e todos se submetem a ele, como representação da figura patriarcal de Deus Pai, a unidade está garantida. No entanto, Inácio sabe que não pode contar unicamente com sua autoridade arrogada para inculcar tal ideia na cabeça de seus destinatários. Era necessário que a prática social cotidiana os conduzisse a enxergar o caráter paternal de seu supervisor, de modo a verem nele um pai e não um tirano centralizador. É possível que Inácio só tenha se dado conta disso quando prestes a partir de Trôade, na costa da Ásia, para zarpar rumo a Neapolis, na Macedônia; de fato, somente 
neste momento ele toma a resolução de escrever uma nova carta a Esmirna, desta vez direcionada ao supervisor cristão local, Policarpo.

Na carta, Inácio tece uma série de conselhos ao seu destinatário a respeito de como agir na igreja posta aos seus cuidados. O prisioneiro espera atitudes de Policarpo, especialmente em uma comunidade cristã em que sua posição, como já visto, não se encontrava consolidada, talvez sequer considerada de forma especial enquanto tal. $\mathrm{O}$ supervisor é instado por Inácio a tomar ações que, embora não referidas explicitamente como tal, tendem a realçar o paternalismo da função por meio da manutenção de contatos estreitos com todos os membros: Policarpo deve carregar os fardos de todos, falar com todos individualmente e ajudá-los a carregar suas doenças como "um perfeito atleta" (In.Policarpo 1,2); deve, do mesmo modo, estar especialmente atento aos discípulos mais

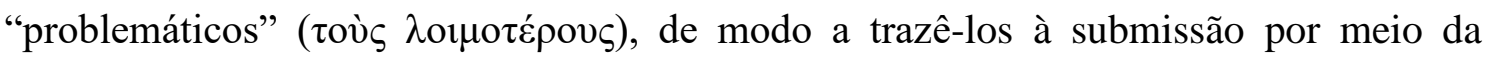
"gentileza" ( $\dot{\varepsilon} v \pi \rho \alpha o ́ \tau \eta \tau 1 ; 2,1)$; deve ser o guardião especialmente das viúvas e não desprezar os escravos, como já visto $(4,1)$, assim como deve evitar às más artes e pregar contra elas $(5,1)$; do mesmo modo, deve exortar os casais a se manterem unidos e fieis, assim como é necessário que toda união se dê somente com a sua aprovação. Em outras palavras, o supervisor Policarpo deve fazer valer o caráter patriarcal de sua função todos os dias e a todo instante, com todos aqueles de cujo cuidado foi encarregado. Aparentemente, era como se Inácio quisesse que todos os fieis de Esmirna pudessem enxergar nas próprias ações de Policarpo uma figura do próprio Deus Pai ao qual adoravam, com toda sua diligência e autoridade. Os âmbitos do sagrado e do doméstico se confundiriam na função do supervisor, de modo que, como representação viva da divindade patriarcal, reuniria em si a prerrogativa de ação na comunidade, tanto de forma coletiva, isto é, no ambiente de culto, quanto individualmente, em sua relação com cada um dos membros da igreja sobre a qual fora designado.

\subsection{3: O supervisor e a ceia sagrada}

Apesar de toda sua estratégia discursiva, com a exortação recorrente para que os cristãos se submetam a seu supervisor, assim como os conselhos dados a Policarpo para que pusesse em prática o caráter paternal de sua função com cada membro de sua igreja, Inácio de Antioquia estava consciente de que somente isso não seria o suficiente para garantir a unidade do grupo por meio de um combate à diversidade. Era necessária uma 
forma de controle social por parte do supervisor ${ }^{146}$, de modo a identificar, e agir contra, aqueles que poderiam questionar sua autoridade e/ou que já estivessem fazendo-o. A solução inaciana está explicitada naquela sentença que, segundo o autor, não era de sua

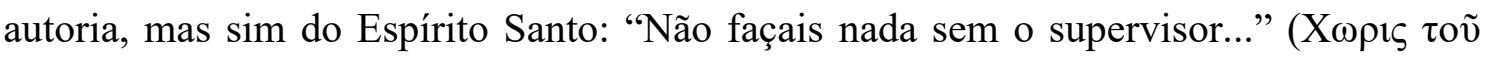

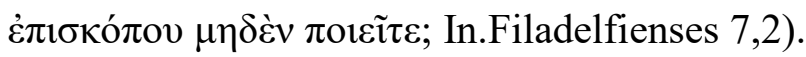

Por que Inácio faz tal clamor? Vimos, no capítulo 2, como as restrições espaciais praticamente impossibilitavam que toda a comunidade de cristãos de uma localidade se reunisse em uma única casa, ao menos pelo que podemos identificar a partir das cartas de Paulo. Exceções existiam, como no caso de Gaio de Corinto, o qual, segundo Paulo, recebia toda a igreja em sua casa. Neste caso, muito provavelmente, ou o patrono do grupo dispunha de uma soma considerável de dinheiro, de modo a possuir uma edificação suficientemente grande para receber todo o grupo, ou a comunidade de cristãos da cidade era consideravelmente restrita.

No caso das igrejas da Ásia à época de Inácio, essa não parecia ser a regra na maioria dos casos, e ele se ressente desse fato. Mesmo com todo o respeito que demonstra, por exemplo, com a igreja de Éfeso, Inácio não deixa de vocalizar suas repreensões nesse sentido:

Que ninguém se engane: se alguém não está dentro do altar (c่ò̀ $\mu$ ì

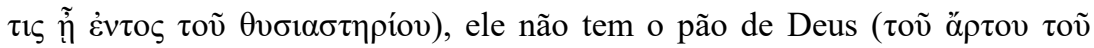
$\theta \varepsilon o v ̃)$; pois se a oração de um ou dois tem tamanho poder, quanto mais aquela do supervisor e de toda a igreja ( Aquele, portanto, que não vem, demonstra, desta forma, arrogância ( arrogante". Ansiemos, portanto, por não resistir ao supervisor, de modo que possamos ser obedientes a Deus. (In.Efésios 5,2-3)

Alguns cristãos efésios se recusam a participar da "oração do supervisor e de toda a igreja". Inácio critica-os, chamando-os de "arrogantes", provavelmente colocando como pressuposto que considerassem sua própria oração individual mais poderosa que a de toda a coletividade reunida em torno do supervisor. No entanto, podemos nos perguntar se os

\footnotetext{
146 Schoedel nota que a exortação de Inácio para que toda união entre cristãos se desse apenas com a aprovação do supervisor (para ele, "bispo") punha em suas mãos "um potente instrumento de controle social - a "endogamia do grupo" (SCHOEDEL, 1985: 273). Embora não nos foquemos tanto neste ponto, voltando-nos para o controle social por meio do ritual da ceia sagrada, não ignoramos a importância de tal ferramenta, sutilmente abordada por Inácio e que pode ser considerada, como o foi no texto, um traço considerável no desenho patriarcal que é feito pelo prisioneiro das responsabilidades do supervisor.
} 
“arrogantes" referidos pelo autor realmente resistiam isoladamente, ou se, por outro lado, constituíam um ou mais grupos que simplesmente mantinham suas próprias orações coletivas, sem reunir-se com aqueles que se encontravam em torno do supervisor Onésimo. Se em Éfeso paira tal dúvida, em Magnésia este é o caso explícito:

É correto, portanto, não apenas sermos chamados “cristãos", mas

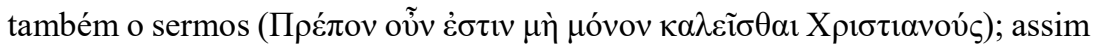

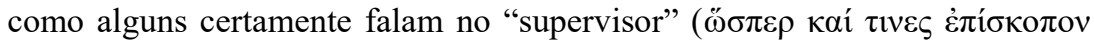

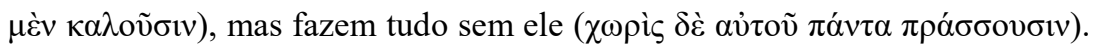
Tais pessoas não me parecem agir em boa consciência, porque não se

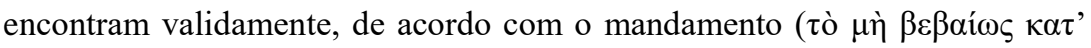

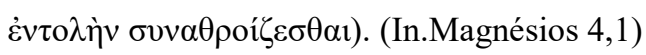

Nesse trecho, Inácio faz menção a um grupo de cristãos que, por mais que deem certo valor à figura do supervisor, preferem insistir no hábito já antigo de manter suas próprias reuniões. O prisioneiro acusa tais reuniões de serem inválidas, uma vez que elas desobedecem ao "mandamento". Não está claro a qual mandamento ele se refere aqui, mas podemos imaginar mais ou menos o quadro no qual se desenvolve o problema. Em outro momento da mesma carta, o autor investe contra um grupo cristão da cidade que

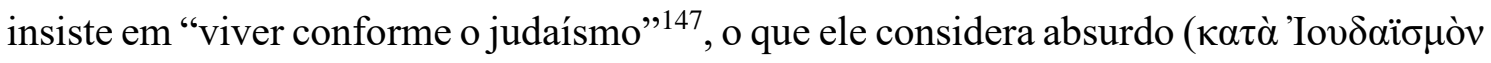
$\zeta \tilde{\omega} \mu \varepsilon v ; 8,1)$. Tal grupo, ao que parece, não se reunia no primeiro dia da semana, como aquele em torno de Damas, o supervisor, e sim no sábado, uma vez que Inácio utiliza contra ele o exemplo dos primeiros convertidos: "Se, portanto, aqueles que viviam nos velhos caminhos vieram para a novidade de esperança, não mais mantendo o sábado

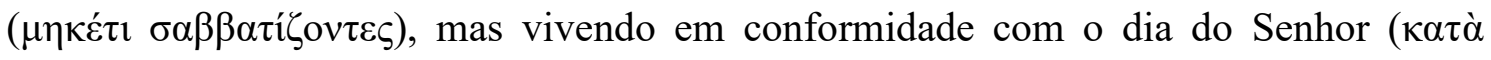

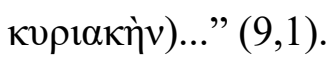

O caso de Magnésia é um exemplo claro de como a existência de diferentes reuniões em diferentes casas poderia ser muito propícia à manifestação da diversidade própria ao cristianismo dos primeiros séculos. Um grupo que tivesse, como parte de sua identidade, a continuidade do seguimento da lei hebraica não poderia reunir-se no mesmo dia que aqueles que não a seguissem mais. Iriam, ao invés, escolher outro local, conforme

\footnotetext{
147 Para uma análise das referências na documentação cristã mais antiga acerca de cristãos que permaneciam fieis às práticas rituais judaicas (normalmente denominados "judaizantes", tanto pela literatura teológica quanto pela historiografia), ver SELVATICI, 2013. Selvatici destaca, no referido artigo, que Inácio de Antioquia é um dos autores do século II d.C. que se dedicam a advertir seus leitores contra os "judaizantes" (Ibidem: 34).
} 
o costume de quase a metade de um século, ainda que querendo manter a comunhão com o supervisor local (o que, para Inácio, era impossível). No entanto, em outros lugares, a reunião autônoma poderia ser o espaço propício também para a continuidade de uma autoridade paralela àquela do supervisor, ao mesmo tempo que manifestando diferenças teológicas. Vimos, por exemplo, como no caso de Esmirna um líder da comunidade parecia não conferir tamanha importância à posição de Policarpo enquanto supervisor (In.Esmirniotas 6,1). O contexto geral da carta de Inácio aos cristãos de Esmirna, assim como o do trecho referido em especial, sugere-nos que esse líder estivesse à frente daquele grupo, condenado pelo prisioneiro, que insistia em defender o caráter meramente aparente da vinda de Cristo. Sobre eles, o autor escreve que "permanecem afastados da ação de

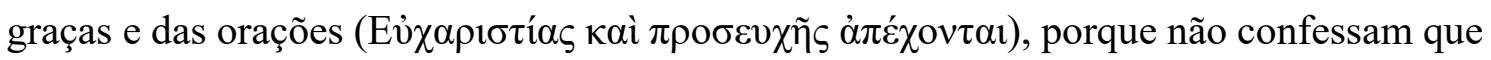

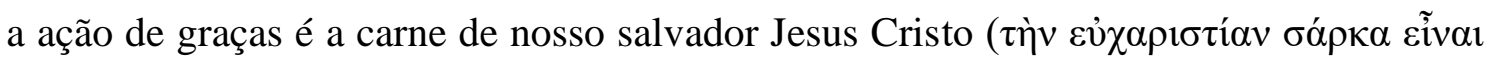

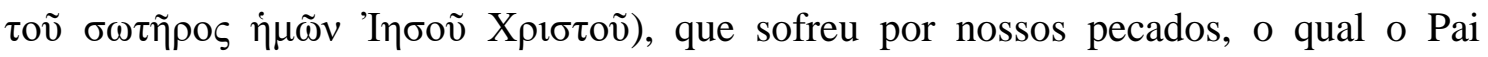
ressuscitou por sua bondade" (In.Esmirniotas 7,1). Apesar do que diz explicitamente Inácio, o mais provável não é que os docetistas referidos não fizessem qualquer reunião ou oração, mas sim que se reunissem de forma apartada, de modo a não comungar com aquilo que eles consideravam ser um erro teológico, tendo um líder próprio à sua frente.

Qual a solução, portanto, segundo Inácio? Ela é relativamente simples: nenhuma reunião deve ser feita sem o supervisor ou alguém por ele indicado. A reunião única é necessária de modo a tornar visível a unidade da igreja local por meio do encontro direto entre os fieis e aquele que, tanto na vida da comunidade quanto na própria ceia sagrada, serve de representação ritual do próprio Deus Pai, enquanto os anciãos (todos reunidos no mesmo local) e os servidores representam outras realidades:

...eu vos exorto: ansiai por fazer tudo na concórdia de Deus ( $\dot{\varepsilon} v$ ó $\mu$ ovoí $\alpha$ $\theta \varepsilon$ õ̃), com o supervisor estabelecido sobre vós no lugar de Deus (

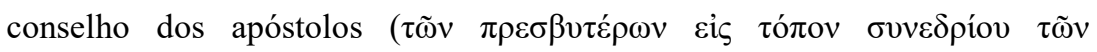

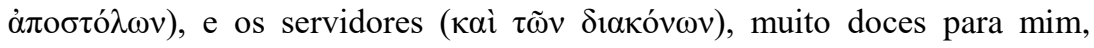

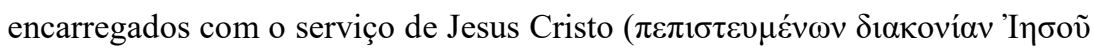

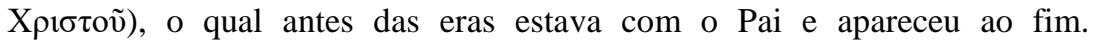
(In.Magnésios 6,1)

Aqui temos claramente uma descrição de Inácio de qual é a função ritual que cada um dos líderes da igreja deve exercer em sua ceia ideal. Nesse sentido, Brent vai além, ao 
enxergar aqui também uma pista da disposição espacial idealizada por Inácio, com o supervisor permanecendo em uma posição ao centro da guirlanda formada pelos anciãos; tal disposição, segundo o autor, parece estar implícita em outro trecho de In.Magnésios, onde encontra-se escrito: “Ansiai, portanto, por serem confirmados nos preceitos do Senhor... com vosso justíssimo supervisor, e vossa coroa espiritual dignamente tecida

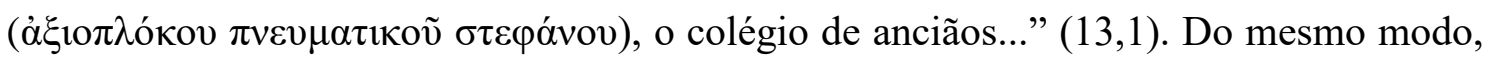
Inácio retorna ao mesmo tema em In.Tralianos 2,2-3, logo antes do trecho, já citado anteriormente, de 3,1, onde ele fala do supervisor "como um tipo do Pai":

É necessário, portanto (como é de vosso feitio), não fazer nada sem o

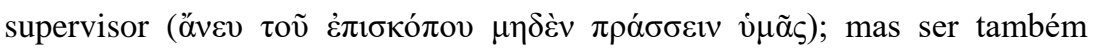
submissos ao colégio de anciãos como aos apóstolos de Jesus Cristo ( $\dot{\alpha} \lambda \lambda$ '

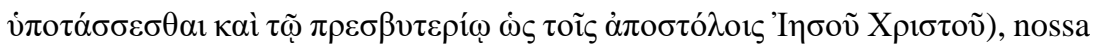
esperança, em quem seremos encontrados, se nele vivermos; e também é necessário que aqueles que são servidores dos mistérios de Jesus Cristo ( $\tau$ ov̀

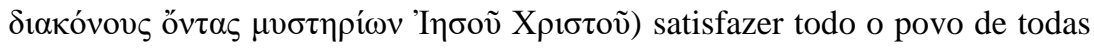
as maneiras; pois eles não são servidores de comida e bebida, mas servos da

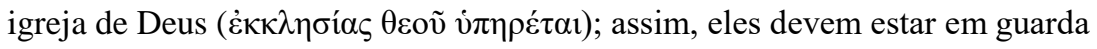
contra reclamações como se fossem fogo.

Os mesmos líderes encontram-se sempre juntos, na visão de Inácio, no mesmo ambiente ritual. A necessidade da presença do supervisor é justificada, para o autor, pela impossibilidade de se executar uma reunião sagrada sem a pessoa encarregada de ser a representação do próprio Deus Pai; é como se, sem ele, o ritual ficasse manco: estariam presentes as representações dos apóstolos e do próprio Cristo, mas não do Pai, o ordenador divino de todas as coisas. Em outras palavras, a ceia sagrada (assim como, provavelmente, outros tipos de reunião, como aquela de caráter deliberativo) não estaria completa se não servisse de representação fiel da corte celeste, onde se encontram Deus, Jesus Cristo e os apóstolos. Tal representação do céu seria particularmente familiar aos cristãos da Ásia, considerando sua proximidade e semelhança com aquela descrição feita pelo profeta João, em seu Apocalipse:

Fui imediatamente movido pelo Espírito: eis que havia um trono no céu, e no trono, Alguém sentado. (...) Ao redor desse trono estavam dispostos vinte

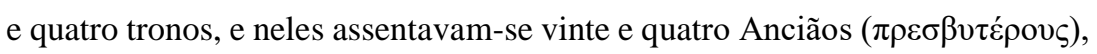
vestidos de branco e com coroas de ouro na cabeça. (...) Com efeito, entre o 


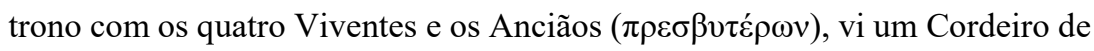
pé, como que imolado. (Apocalipse 4,2.4-5,6)

Uma vez que uma ceia sagrada nunca estaria completa se o teatro sagrado não contasse com todos os seus personagens, no caso da ausência do supervisor, apenas alguém por ele indicado poderia executar sua função ritual em seu lugar:

Que ninguém faça nada sem o supervisor que tenha a ver com a igreja

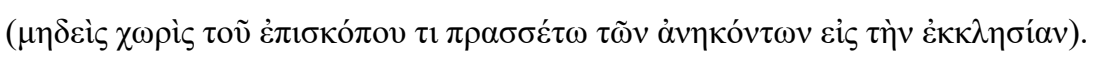

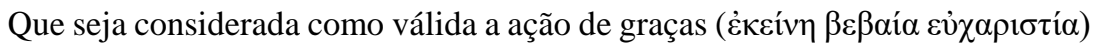
que é celebrada sob o supervisor ou alguém a quem ele o tenha encarregado (ì $\tilde{\omega}$ ò̀ $\alpha$

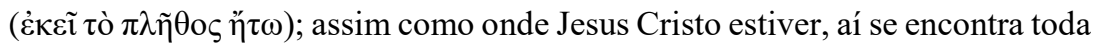

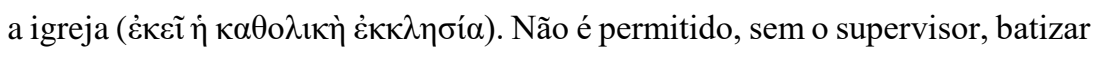

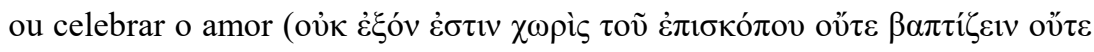

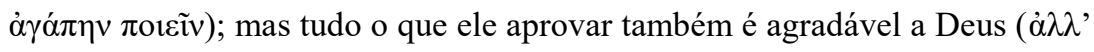

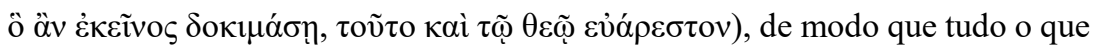
fizerdes possa ser certo a válido. (In.Esmirniotas 8,1-2)

A presença do supervisor (ou de seu representante), para Inácio, confere validade a qualquer ação ritual da comunidade, uma vez que elas recebem o selo de compromisso com a unidade. O governante da igreja, como representação de Deus Pai, garante a legitimidade de tal ação, como um pai que lidera um culto doméstico. A questão, porém, não permanece no âmbito da mera analogia, mas envolve principalmente as consequências práticas do ideal de autoridade expresso pelo prisioneiro. A necessidade da presença do supervisor confere ao mesmo uma ferramenta importante de controle social, pode ser captado entre as linhas de um trecho singular da carta de Inácio aos cristãos tralianos:

Guardai-vos, portanto, de tais pessoas [docetistas]. Assim será para vós se não vos exaltardes e se fordes inseparáveis de Jesus Cristo, do supervisor e das ordenanças dos apóstolos. Aquele que está dentro do altar é puro (ó Ėvtòs

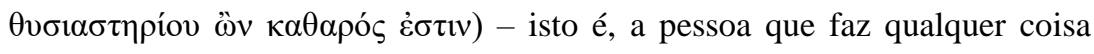
apartado do supervisor, do colégio de anciãos e do servidor, não está puro em

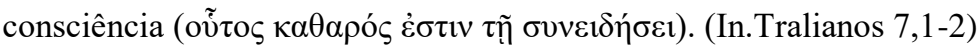


Ao proferir tal sentença enquanto "acorrentado em Cristo" e profeta com conhecimento oculto (ver In.Tralianos 5, já citado acima), Inácio de Antioquia confere um instrumento inestimável para o supervisor realçar sua autoridade: a ceia sagrada acaba por servir ao mesmo como meio de vigilância, onde ele pode ser "aquele que olha sobre"

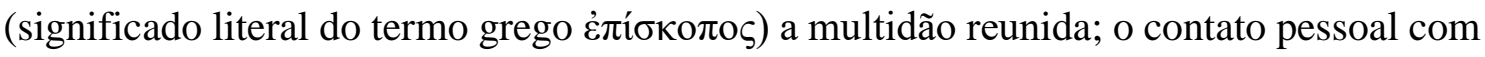
os fieis, também requerido por Inácio dos supervisores, permite de imediato a identificação dos ausentes, possivelmente aqueles que lhe resistem mesmo com a exortação de um mártir próximo a favor de sua autoridade. "Que nada aconteça sem tua

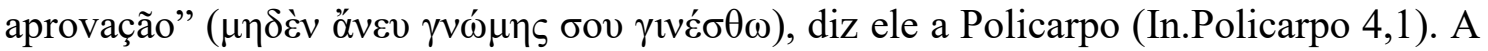
ceia sagrada realizada com o supervisor ao centro é o sinal permanente da unidade da igreja local: aqueles que resistem em abandonar sua antiga autonomia, ou que desejam continuar realizando o mesmo ritual no sétimo dia, ou ainda que não podem aceitar a teologia por trás do banquete com o supervisor no comando, devem ser considerados inimigos da unidade. Para os que pensam em seguir os resistentes, vale um pouco de pedagogia do medo:

Não sejais enganados, meus irmãos: corruptores de lares (oi

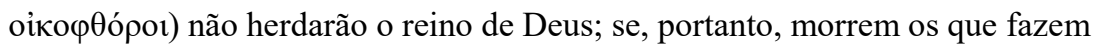
tais coisas no reino da carne, quanto mais se alguém, pelo ensinamento mau

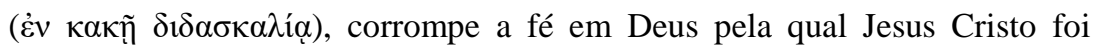

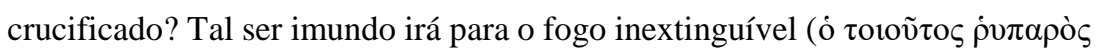

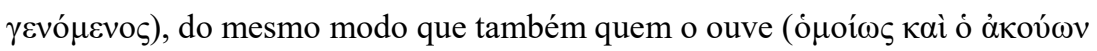

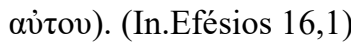

O ritual da ceia sagrada para Inácio, portanto, deve necessariamente ser um ambiente no qual a unidade prevaleça com a vigilância do supervisor, um meio de controle sobre os que frequentam a reunião inclusive pela sua faculdade de exortar os presentes, como sugerido por In.Policarpo 5,1. Se os discordantes insistirem em se reunir à parte, não o farão mais por uma autonomia de costume, mas por uma exclusão completa, inclusive no âmbito do convívio social: "É correto, portanto, evitar tais pessoas e não falar

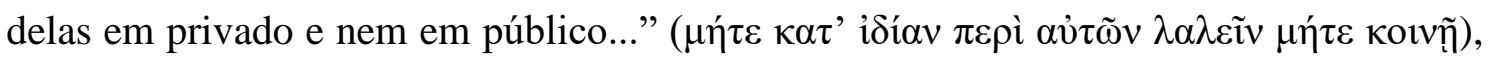
escreve ele aos esmirniotas (In.Esmirniotas 7,2). Por outro lado, uma vez que a comunidade local seja demasiadamente grande para ser contida em uma única reunião, em um único local, como certamente era o caso da igreja de Éfeso, que mais ceias sagradas sejam organizadas: 
Ansiai, portanto, por vos encontrardes com mais frequência para a ação

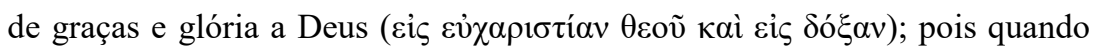

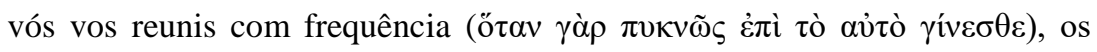
poderes de Satanás são quebrados, e sua destrutividade é esfacelada pela

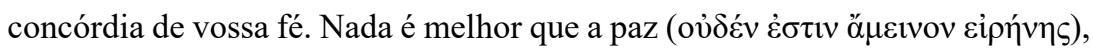
pela qual toda guerra de seres celestiais e terrenos é destruída. (In.Efésios 13)

Inácio de Antioquia espera que, com seu próprio sacrifício, o seu clamor seja ouvido, de modo que o supervisor de cada igreja seja encarado de uma outra forma pelos cristãos. A diversidade, desta forma, deve ceder espaço à unidade em torno de uma mesma mesa, na qual deve ser representado o teatro sagrado da corte celestial. Tudo isso com o supervisor "vigilante com um espírito que não dorme" (In.Policarpo 1,3). Por esse motivo, sempre que Inácio faz um retrato ideal de uma igreja unida, ele sempre é construído a partir de referenciais ritualísticos:

Assim como, portanto, o Senhor não fez nada sem o Pai - estando a ele unido - nem por ele e nem pelos apóstolos, também vós não façais nada sem o

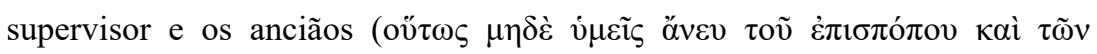
$\pi \rho \varepsilon \sigma \beta v \tau \varepsilon \dot{\varepsilon} \rho \omega \nu \mu \eta \delta \dot{v} v \pi \rho \alpha ́ \sigma \sigma \varepsilon \tau \varepsilon)$, nem deixeis que nada pareça certo por vós

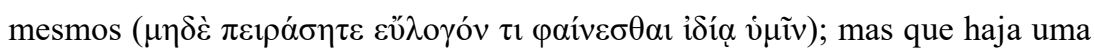
prece em comum, uma petição, uma mente, uma esperança no amor, em alegria sem culpa, que é Jesus Cristo, do qual nada é melhor. Todos vós correi juntos

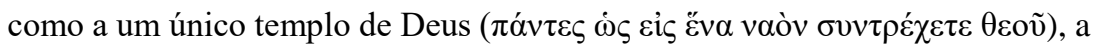

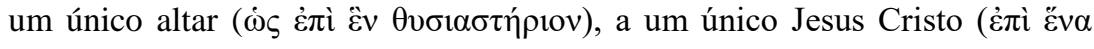

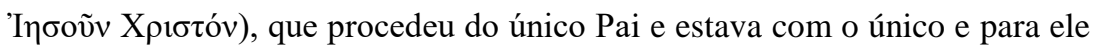
retornou. (In.Magnésios 7)

Não sejais enganados, meus irmãos: se alguém segue um cismático ( $\varepsilon$ î

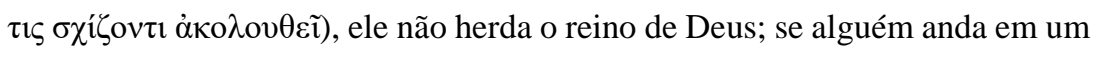
propósito estranho, essa pessoa não se conforma com a paixão [de Cristo].

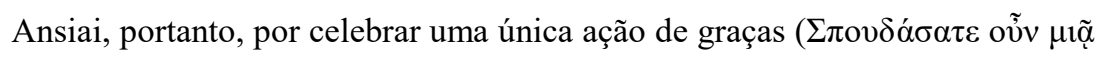

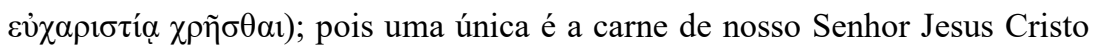

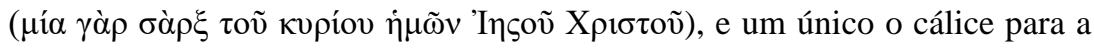

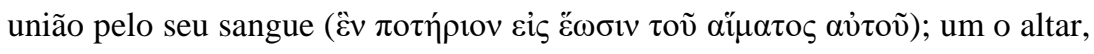
assim como um é o supervisor ( anciãos e os diáconos, meus co-escravos; de modo que tudo o que façais o seja de maneira divina (ó èòv $\pi \rho \alpha ́ \sigma \sigma \eta \tau \varepsilon, \kappa \alpha \tau \grave{\alpha} \theta \varepsilon \dot{\nu} v \pi \rho \alpha ́ \sigma \sigma \eta \tau \varepsilon$ ). (In.Filadelfienses 3,3-4,1) 


\section{Conclusões gerais}

Apesar de ter-nos legado somente um curto epistolário de apenas sete cartas, Inácio de Antioquia se mostrou uma fonte com muito o que dizer, com as perguntas certas e uma problematização específica. Não apenas ele, mas também as fontes cristãs com alguma conexão com o cristianismo existente na província da Ásia Proconsular provenientes da segunda metade do século I d.C. Findando os capítulos analíticos da dissertação, podemos encerrar o trabalho com algumas conclusões gerais.

Uma primeira conclusão é que o ambiente no qual se reuniam os cristãos asiáticos conforme o modelo implantado pelo apóstolo Paulo, a saber, o doméstico (seja por iniciativa do mesmo ou seguindo uma tradição anterior), mostrou-se como um fator de peso no molde das relações sociais internas às comunidades em seu primeiro século de existência. De fato, à medida que as igrejas vão se tornando grupos fixos e de fundação não mais tão recente, podemos enxergar uma crescente confusão entre o ambiente de reuniões deliberativas e cultuais, a household (oĩ $\delta$ ), e a própria igreja enquanto entidade

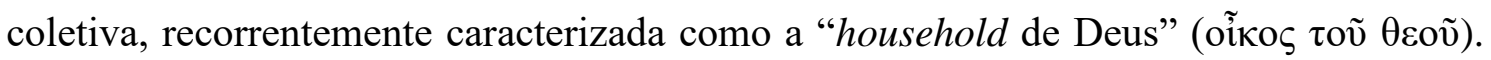
De certa forma, o próprio Paulo de Tarso possui papel neste processo, sobretudo com sua forma paternalista de dirigir-se àqueles por ele convertidos. Por outro lado, a caracterização da igreja como household parece apontar, porém, para dois sentidos, principalmente após a morte do fundador: em primeiro lugar, para um desenvolvimento do aspecto ressocializador do culto cristão, particularmente do batismo e da ceia sagrada, com o estreitamento dos novos laços sociais formados; em segundo lugar, para uma busca pelo funcionamento da igreja como uma household ideal, em que cada membro possui deveres e funções. No segundo caso, o primeiro passo parece ser a moralização das relações domésticas, como entre maridos e esposas, e senhores e escravos (aparentemente presumindo serem eles todos membros da comunidade), conforme o que pode ser visto em Colossenses (3,18-4,1) e Efésios (5,21-6,9). O segundo passo, identificável pela 1Timóteo, é a caracterização da própria administração da igreja como a direção de uma household, ainda que com designações inspiradas nas existentes em associações voluntárias em geral e sinagogas. Neste segundo momento, conforme os requisitos

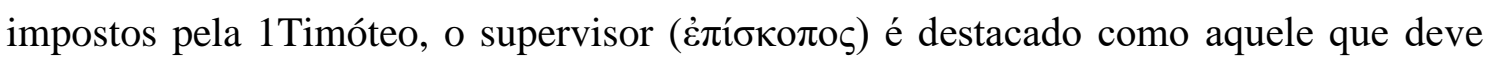
saber guiar bem a sua própria household, mantendo seus filhos em submissão, de modo a estar apto a fazer o mesmo na "household de Deus" (1Timóteo 3,4-5). 
A segunda conclusão é que a caracterização paternalista do supervisor cristão não é uma particularidade da 1Timóteo, mas também parte essencial do discurso inaciano. De fato, Inácio demonstra partir do princípio da "igreja-household" ao colocar, em suas cartas, o supervisor como uma representação do próprio Deus Pai, o ícone patriarcal supremo do imaginário cristão mais antigo, fundamental para a própria identidade dos fieis como seres especiais frente à sociedade; é isso que sugere o próprio rito batismal paulino, se dele fizer mesmo parte a exclamação aramaica "Abba!", conforme as palavras do próprio Paulo (cf. Gálatas 4,6). No entanto, ao mesmo tempo que Inácio parece dialogar com a tendência expressada pela 1Timóteo, ele também vai além: o supervisor não é um mero administrador, conforme Inácio reforça a Policarpo, mas deve possuir uma relação de proximidade paternalista com os membros da comunidade, influindo em sua intimidade e fazendo-lhes exortações, em consonância com o modelo de supervisão cristã expressado pelos Atos dos Apóstolos aos anciãos supervisores de Éfeso. Aqui, o monepiscopado defendido por Inácio aponta para um sentido que pode, por uma leitura de seus referenciais, ser considerado "monárquico", usando a designação clássica da historiografia. Podemos chegar a tal conclusão pelo fato de o autor ter a figura do patriarca da household como referencial para o seu supervisor; de fato, não é a presença dos anciãos e supervisores que, na visão inaciana, garante a validade de uma reunião, mas sim a do supervisor, assim como é somente a Policarpo que Inácio dirige conselhos para uma atitude paternalista para com todos os membros do grupo. Não devemos seguir a referida historiografia, contudo, quando pinta nossa fonte como sendo representante de um estado de coisas em que um bispo monárquico é regra: ao invés, devemos recordar que boa parte das vezes em que Inácio apresenta uma imagem da unidade comunal ideal, ele espera uma comunhão por parte dos fieis com o supervisor em conjunto com os anciãos e servidores do grupo. Do mesmo modo, o caso de Éfeso, em que Inácio se sente compelido a requisitar a permanência custosa de um membro da comunidade local à revelia de seu supervisor (que se encontrava presente com ele), é sinal inequívoco de que em uma das principais igrejas da Ásia Proconsular (se não a igreja principal) o que ocorria estava longe de ser o que ele idealizava, obrigando-o a lidar com a realidade posta.

Se na conclusão anterior concedemos parcialmente um ponto para a historiografia clássica, nossa terceira vai completamente contra a leitura da mesma sobre o desenvolvimento das relações de autoridade nas igrejas da virada do século I para o II d.C. De fato, a análise feita da documentação aponta para uma convivência entre formas de liderança largamente consideradas como inconciliáveis pela historiografia até a 
segunda metade do século XX, podendo existir apenas em uma relação de sucessão. Profetas e líderes fixos da comunidade coexistem tanto nos Atos dos Apóstolos quanto em 1Timóteo: no primeiro caso, a mesma narrativa que apresenta o apontamento e a instrução dos anciãos supervisores acerca de suas funções, indica a existência de profetas percorrendo as igrejas e exortando-as como um fenômeno normal do cristianismo no primeiro século; no segundo caso, é dito que a escolha do próprio Timóteo para exercer um determinado serviço teria sido acompanhada de profecias, um provável indicativo da presença de profetas no processo. Tudo se torna mais impressionante com a representação feita por Inácio de si mesmo. Mesmo que indique uma vez ou outra sua posição (possivelmente não tão sólida e inconteste) como supervisor da igreja de Antioquia, na Síria, ele prefere realçar uma suposta ligação especial sua com o Espírito de Deus, que lhe concede tanto conhecimentos especiais quanto a missão de proferir uma mensagem sua em prol da unidade comunal, com os cristãos não devendo fazer nada sem a presença de seu supervisor. Em outras palavras, Inácio coloca uma caracterização própria como profeta à frente de sua condição de supervisor cristão. Ambas as formas de autoridade se encontram nele personificadas, não apenas conviventes, como também complementares.

Por fim, a última conclusão da pesquisa (e a mais significativa para a historiografia, em nossa visão) decorre do seguinte ponto: o supervisor que, em documentos anteriores, não tem destacada entre suas funções qualquer parte especial no culto, passa a ser, na idealização inaciana, o próprio centro da ceia sagrada, sendo inválidas quaisquer outras reuniões que não se encontrem, de uma forma ou de outra, sob a sua égide. Esse ponto do ideal de Inácio é o desenvolvimento lógico do apontamento do supervisor como representação de Deus Pai. É muito provável inclusive que nossa fonte esperasse que tal representação se desse, fundamentalmente, em um contexto litúrgico, e que, a partir daí, tivesse consequências para todas as relações entre o supervisor e os outros fieis. Ocorre, porém, que a validade exclusiva de reuniões

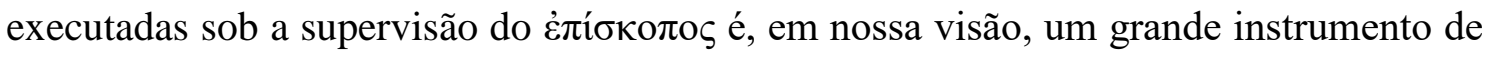
controle social idealizado por Inácio, apontando para as consequências práticas de seu modelo. Uma vez que a unidade por ele imaginada exclui qualquer diversidade interna do grupo, tanto em termos doutrinais quanto rituais, a reunião única sob a autoridade do supervisor único poderia perfeitamente servir de meio para que o mesmo tivesse considerável controle de seus frequentadores, sobretudo considerando sua prerrogativa de fazer exortações ao grupo reunido. No entanto, para além disso, serviria também para a identificação de "elementos problemáticos", que poderiam se manifestar (na visão de 
Inácio) sobretudo na recusa de comparecimento à ceia única para a manutenção de reuniões independentes. Esse instrumento mostra-se mais significativo em um período em que a diversidade teológica mostra-se no início da formação de uma autoconsciência. Sugere-o não apenas a resistência de alguns grupos recriminados por Inácio (sendo de especial nota aqueles que o faziam em Magnésia, visando manter o respeito judaico ao sétimo dia), mas também outros documentos do cristianismo em geral do mesmo período. A Primeira Carta de João, por exemplo, não é nada mais que uma exortação contra um grupo que, aparentemente, resolveu livremente afastar-se daquele representado pelo autor (cf. 1João 2,18-28). Também um "apócrifo", o Evangelho de Tomé, parece ser obra de um autor que, possivelmente representando um grupo cristão específico, tem consciência da existência de outros que tinham os evangelhos de Mateus e Marcos em alta conta, ao mesmo tempo que deles visa se apartar (cf. Tomé 13). Neste contexto, a reunião única defendida por Inácio (inspirado pelo Espírito de Deus, segundo ele) ao mesmo tempo que visa, certamente, uma integração social do grupo por meio de sua coesão, também tem seu efeito inverso, tendendo para o favorecimento e estímulo à desintegração entre os grupos cristãos, um processo que, de fato, encontra um crescendo justamente a partir do século II d.C.

Não é possível dizermos que as cartas inacianas tiveram efeito direto ou mesmo indireto neste sentido, uma vez que não podemos inferir a extensão de sua aceitação entre as comunidades da Ásia às quais se dirigiu. Podemos, no entanto, concluir o estudo notando que o instrumento cristão de controle social pelo culto, idealizado por Inácio, aponta para uma estrutura de longa duração da história do cristianismo, que é a utilização da ceia sagrada como fator de exclusão e marginalização social por meio do controle dos que a ela têm acesso. O caso mais característico, neste sentido, é o da excomunhão. Significativamente, sobretudo a partir da Antiguidade Tardia, o detentor da prerrogativa de execução de tal pena é justamente o bispo, desenvolvimento histórico direto de nosso

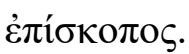




\section{Bibliografia}

\section{Documentação primária impressa}

Bíblia de Jerusalém, 4a impressão. São Paulo: Editora Paulus, 2006.

Biblia sacra utriusque Testamenti editio Hebraica et Graeca. Stuttgart: Deutsche Bibelgesellschaft, 1994.

EHRMAN, Bart D.. The Apostolic Fathers Volume I. Cambridge (Massachussets): Loeb Classical Library, 2003.

EUSÉBIO DE CESAREIA, Histoire ecclésiastique. Paris: Édition du Cerf, 1994.

HENNECKE, E. New Testament Aprochrypha: Vol. 1. Trowbridge, Wiltshire: SCM Press, 1963.

IRINEU DE LYON, Contre les hérèsies. Paris: Éditions du Cerf, 2002.

MILAVEC, Aaron. The Didache: Text, Translation, Analysis, and Commentary. Collegeville: Michael Glazier Books, 2003.

SCHOEDEL, William R.. Ignatius of Antioch: A Commentary on the Letters of Ignatius of Antioch. Minneapolis: Fortress Press, 1985.

\section{Bibliografia instrumental}

BLOCH, Marc. Apologia da História ou o Ofício do Historiador. Rio de Janeiro: Jorge Zahar Editora, 2002.

BRAUDEL, Fernand. O Mediterrâneo e o Mundo Mediterrânico na Época de Filipe II, volume II. Lisboa: Publicações Dom Quixote, 1995.

COSTA, Emilia Viotti da. Coroas de glória, lágrimas de sangue. São Paulo: Companhia das Letras, 1998.

DURKHEIM, Émile. As Formas Elementares da Vida Religiosa. São Paulo: Martins Fontes, 1996.

GINZBURG, Carlo. Mitos, emblemas, sinais: Morfologia e história. São Paulo: Companhia das Letras, 2003.

GODELIER, Maurice. L'idéel et le matériel. Paris: Fayard, 1984.

HENNECKE, E.. New Testament Apocrypha, volume one: Study edition. Trowbridge: SCM Press Ltd., 1973.

KRONMAN, Anthony. Max Weber. Rio de Janeiro: Elsevier, 2009. 
MANZANARES, César Vidal. Dicionário Histórico do Cristianismo. Aparecida: Editora Santuário, 2005.

SHREINER, Josef e DAUTZENBER, Gerhard. Forma e exigências do Novo Testamento, $2^{\mathrm{a}}$ Ed.. São Paulo: Editora Paulus, 2004.

SOBOUL, Albert. Descrição e medida em história social. In: GODINHO, Vitorino Magalhães (org.). A História Social: problemas, fontes e métodos. Lisboa: Edições Cosmos, 1973.

WEBER, Max. Economy and Society: An Outline of Interpretive Sociology. Berkeley: University of California Press, 1978.

WEGNER, Uwe. Exegese do novo testamento: Manual de metodologia. São Leopoldo: Sinodal, 1998.

\section{Obras de apoio}

ALBRIGHT, W. F. e MANN, C. S.. Matthew: A new translation with introduction and commentary. Nova York: Doubleday, 1971.

ALTANER, Berthold e STUIBER, Alfred. Patrologia, $4^{\text {a }}$ Ed. São Paulo: Editora Paulus, 2010 .

ANDO, Clifford. The Administration of the Provinces. In: POTTER, David S. (org.). A Companion to the Roman Empire. Malden: Blackwell Publishing, 2006.

ARENS, Eduardo. Ásia Menor nos tempos de Paulo, Lucas e João: Aspectos sociais e econômicos para a compreensão do Novo Testamento, $2^{\mathrm{a}}$ Ed.. São Paulo: Editora Paulus, 2008.

ATTRIDGE, Harold W.. Johannine Christianity. In: MITCHELL, Margaret M. e YOUNG, Frances M.. The Cambridge History of Christianity, vol. I: Origins to Constantine. Cambridge: Cambridge University Press, 2006.

B. MARTIN, Dale. New Testament History \& Literature. Yale: Yale University Press, 2012.

BARTH, Markus. Ephesians: Introduction, translation and commentary on chapters 13. Londres: Yale University Press, 2008.

BARTH, Markus e BLANKE, Helmut. Colossians: A new translation with introduction and commentary. New Haven: Yale University Press, 2005. 
BAUER, Walter. Orthodoxie et hérésie aux débuts du christianisme. Paris: Éditions du Cerf, 2009.

BAUCKHAM, Richard. For Whom Were Gospels Written? In: BAUCKHAM, Richard (org.). The Gospels for All Christians: Rethinking the Gospel Audiences. Grand Rapids, Michigan/Cambridge, RU: William B. Eerdmans Publishing Company, 1998.

Jesus e as testemunhas oculares: Os Evangelhos como testemunhos de testemunhas oculares. São Paulo: Paulus, 2011.

John for Readers of Mark. In: BAUCKHAM, Richard (org.).

The Gospels for All Christians: Rethinking the Gospel Audiences. Grand Rapids, Michigan/Cambridge, RU: William B. Eerdmans Publishing Company, 1998.

BAUR, Ferdinand Christian. The Church History of the First Three Centuries. Londres: Williams and Norgate, 1879.

BEARD, Mary, NORTH, John e PRICE, Simon. Religions of Rome: Volume I - A History. Cambridge: Cambridge University Press, 1998.

BONNARD, Pierre. Les épîtres Johanniques. Genebra: Labor et Fides, 1983.

BRENT, Allen. Ignatius of Antioch: A Martyr Bishop and the Origin of Episcopacy. Londres: T \& T Clark, 2009.

BROWN, Raymond E.. Rome. In: BROWN, Raymond E. e MEIER, John P. Antioch \& Rome: New Testament Cradles of Catholic Christianity. Nova York/Mahwah, Nova Jersey: Paulist Press, 2004.

The Churches the Apostles Left Behind. Nova York: Paulist

Press, 1984.

A comunidade do discípulo amado. São Paulo: Editora Paulus,

2011.

An Introduction to the New Testament. Nova York: Doubleday, 1997.

BURTCHAELL, James Tunstead. From synagogue to church: Public services and offices in the earliest Christian communities. Cambridge: Cambridge University Press, 1992.

BYRNE, Brendan. A Carta aos Filipenses. In: BROWN, Raymond E., FITZMYER, Joseph A. e MURPHY, Roland E. (org.). Novo Comentário Bíblico São Jerônimo: Novo Testamento e Artigos Sistemáticos. São Paulo: Academia Cristã e Paulus, 2011.

CAMPENHAUSEN, Hans Von. Ecclesiastical authority and spiritual power in the Church of the first three centuries. Londres: Black, 1969. 
CARREZ, Maurice. A vida de Paulo. In: CARREZ, Maurice, DORNIER, Pierre, DUMAIS, Marcel e TRIMAILlE, Michel (org.). As cartas de Paulo, Tiago, Pedro e Judas. São Paulo: Editora Paulus, 2008.

CHADWICK, Henry. The Early Church. Londres: Penguin Books, 1967.

CHASTAGNOL, André. Le Sénat Romain à l'époque imériale: Recherches sur la composition de l'Assemblée et le statut de ses membres. Paris: Les Belles Lettres, 1992. COLLINS, John J. A imaginação apocalíptica: Uma introdução à literatura apocalíptica judaica. São Paulo: Paulus, 2010.

DANIÉLOU, Jean. Dos primórdios a São Gregório Magno, in ROGIER, L.-J., AUBERT, Roger e KNOWLES, M. D.. Nova História da Igreja, vol. 1. Petrópolis: Editora Vozes, 1968.

DAVIES, Stevan L. The Predicament of Ignatius of Antioch. In: Vigiliae Christianae, Vol. 30, No 3. Leiden: Brill, 1976.

DESTRO, Adriana e PESCE, Mauro. Formas Culturais do Cristianismo Nascente. Aparecida: Editora Santuário, 2010.

DILLON, Richard J. Atos dos Apóstolos. In: BROWN, Raymond E., FITZMYER, Joseph A. e MURPHY, Roland E. (org.). Novo Comentário Bíblico São Jerônimo: Novo Testamento e Artigos Sistemáticos. São Paulo: Academia Cristã e Paulus, 2011.

DUBOIS, Jean-Daniel. Polêmicas, poder e exegese: o exemplo dos gnósticos antigos no mundo grego. In: ZERNER, Monique. Inventar a heresia?: Discursos polêmicos e poderes antes da Inquisição. Campinas: Editora Unicamp, 2009.

DUCHESNE, Lous Marie Olivier. Histoire ancienne de l'Église. Paris: E. de Boccard, 1929.

DUNN, James D. G. The Theology of Paul the Apostle. Londres/Nova York: T \& T Clark, 1998.

ECK, Werner. Provincial Administration and Finance. In: BOWMAN, Alan K., GARNSEY, Peter e RATHBONE, Dominic. The Cambridge Ancient History, Volume IX: The High Empire, A.D. 70-192. Cambridge: Cambridge University Press, 2000.

EDWARDS, Mark. The devolpment of office in the early church. In: ESLER, Philip F. (org.). The early Christian world. Nova York: Routledge, 2000.

FERGUSON, Everett. Backgrounds of Early Christianity. Grand Rapids, Michigan: William B. Eerdmans Publishing Company, 3 ed., 2003. 
Baptism in the Early Church: History, Theology, and Liturgy in the First Five Centuries. Grand Rapids, Michigan: William B. Eerdmans Publishing Company, 2009.

FERROUX, Henri-Louis. Frotières civiques et maîtrise du territoire : un enjeu pour la cité grecque sous le Haut-Empire (Ier-IIIer siècle apr. J.-C.). In: BRU, Hadrien, KIRBIHLER, François e LEBRETON, Stéphane. L'Asie Mineure dans l'Antiquité: Échanges, populations et territoires. Rennes: Presses Universitaires de Rennes, 2009.

FINLEY, M. I. A economia antiga. Porto: Edições Afrontamento, 1986.

FINN, Thomas M.. Mission and expansion. In: ESLER, Philip F. (org.). The early Christian world. Nova York: Routledge, 2004.

FITZMEYER, Joseph A.. The acts of the Apostles: A new translation with introduction and commentary. Londres: Yale University Press, 2010.

A Carta aos Romanos. In: In: BROWN, Raymond E., FITZMYER, Joseph A. e MURPHY, Roland E. (org.). Novo Comentário Bíblico São Jerônimo: Novo Testamento e Artigos Sistemáticos. São Paulo: Academia Cristã e Paulus, 2011.

First Corinthians: A new translation with introduction and commentary. Londres: Yale University Press, 2008.

The Gospel according to Luke I-IX: Introduction, translation and notes. Londres: Yale University Press, 2009.

The Gospel according to Luke X-XXIV: Introduction, translation and notes. New Haven: Yale University Press, 2005.

FREND, W. H. C.. The Early Church. Minneapolis: Fortress Press, 1991. The Rise of Christianity. Minneapolis: Fortress Press, 1986.

FUNARI, Pedro Paulo e GARRAFFONI, Renata Senna. Economia Romana no Início do Principado. In: SILVA, Gilvan Ventura da, e MENDES, Norma Musco. Repensando o Império Romano: Perspectiva Socioeconômica, Política e Cultural. Rio de Janeiro: Mauad Editora, 2006.

GALSTERER, Hartmut. Local and provincial institutions and government. In: BOWMAN, Alan K., GARNSEY, Peter e RATHBONE, Dominic. The Cambridge Ancient History, Volume IX: The High Empire, A.D. 70-192. Cambridge: Cambridge University Press, 2000.

GARNSEY, Peter e SALLER, Richard. The Roman Empire: Economy, Society and Culture. Berkeley/Los Angeles: University of California Press, 1987. 
GLEASON, Maud W. Greek Cities Under Roman Rule. In: POTTER, David S. (org.). A Companion to the Roman Empire. Malden: Blackwell Publishing, 2006.

GRUEN, Erich S. The Hellenistic World and the Coming of Rome. Berkeley: University of California Press, 1984.

GUARINELLO, Norberto Luiz. O Império Romano e Nós. In: SILVA, Gilvan Ventura da, e MENDES, Norma Musco. Repensando o Império Romano: Perspectiva Socioeconômica, Política e Cultural. Rio de Janeiro: Mauad Editora, 2006.

HÄKKINEN, Sakari. Ebionites. In: MARJANEN, Antti e LUOMANEN, Petri. A Companion to Second-Century Christian “Heretics”. Leiden: Brill, 2008.

HALL, Stuart George. Institutions in the pre-Constantinian ecclesia. In: MITCHELL, Margaret M. e YOUNG, Frances M.. The Cambridge History of Christianity, vol. I: Origins to Constantine. Cambridge: Cambridge University Press, 2006.

HARNACK, Adolf Von. Mission et expansion du christianisme aux trois premiers siècles. Paris : Les Éditions du Cerf, 2004.

HARRILL, J. Albert. Paulo e a escravidão. In: SAMPLEY, J. Paul (org.). Paulo no mundo greco-romano: um compêndio. São Paulo: Editora Paulus, 2008.

HARRIS, W. V. Trade. In: BOWMAN, Alan K., GARNSEY, Peter e RATHBONE, Dominic (org.). The Cambridge Ancient History, Volume IX: The High Empire, A.D. 70192. Cambridge: Cambridge University Press, 2000.

HARRISON, P. N. Polycarp's Two Epistles to the Philippians. Cambridge: Cambridge University Press, 1936.

HATCH, Edwin. The Organization of the Early Christian Churches. Londres: Rivingtons, 1882.

HEMER, Colin J. The Letters to the Seven Churches of Asia in Their Local Setting. Grand Rapids, Michigan: William B. Eerdmans Publishing Company, 2001.

HORGAN, Maurya P. Carta aos Colossenses. In: BROWN, Raymond E., FITZMYER, Joseph A. e MURPHY, Roland E. (org.). Novo Comentário Bíblico São Jerônimo: Novo Testamento e Artigos Sistemáticos. São Paulo: Academia Cristã e Paulus, 2011.

HORRELL, David G. Early Jewish Christianity. In: ESLER, Philip F. (org.). The early Christian world. Nova York: Routledge, 2000.

HURTADO, Larry W. Senhor Jesus Cristo: Devoção a Jesus no Cristianismo Primitivo. Santo André: Paulus e Academia Cristão, 2012. 
ISACSON, Mikael. To Each Their Own Letter: Structure, Themes and Rhetorical Strategies in the Letters of Ignatius of Antioch. Estocolmo: Almqvist \& Wiksell International, 2004.

IZIDORO, José Luiz. Identidades e Fronteiras Étnicas no Cristianismo da Galácia. São Paulo: Paulus, 2013.

JEFFORD, Clayton N.. Reading the Apostolic Fathers: A Student's Introduction, 2a Ed.. Grand Rapids: Baker Academic, 2012.

JEREMIAS, Joachim. Jerusalém no tempo de Jesus: Pesquisas de história econômicosocial no período neotestamentário. São Paulo: Academia Cristã e Paulus, 2010.

JOHNSON, Luke Timothy. The first and second letters to Timothy: A new translation with introduction and commentary. Londres: Yale University Press, 2008.

JOLY, Robert. Le dossier d'Ignace d'Antioche. Bruxelas: Éditions de l'Université de Bruxelles, 1979.

KARRIS, Robert J. O Evangelho Segundo Lucas. In: BROWN, Raymond E., FITZMYER, Joseph A. e MURPHY, Roland E. (org.). Novo Comentário Bíblico São Jerônimo: Novo Testamento e Artigos Sistemáticos. São Paulo: Academia Cristã e Paulus, 2011.

KEHOE, Dennis P. Law and the Rural Economy in the Roman Empire. Ann Arbor: University of Michigan Press, 2007.

KIRBIHLER, François. Territoire civique et population d'Éphèse (Ve siècle av. J.-C.-IIIe siècle apr. J.-C.). In: BRU, Hadrien, KIRBIHLER, François e LEBRETON, Stéphane. L'Asie Mineure dans l'Antiquité: Échanges, populations et territoires. Rennes: Presses Universitaires de Rennes, 2009.

KLAUCK, Hans-Josef. The Roman Empire. In: MITCHELL, Margaret M. e YOUNG, Frances M.. The Cambridge History of Christianity, vol. I: Origins to Constantine. Cambridge: Cambridge University Press, 2006.

KLOPPENBORG, John S.. Collegia and Thiasoi: Issues in function, taxonomy and membership. In: KLOPPENBORG, John S. e WILSON, Stephen G.. Voluntary associations in the Graeco-roman world. Nova York: Routledge, 1996.

KLUTZ, Todd. Paul and the development of Gentile Christianity. In: ESLER, Philip F.. The early Christian world. Nova York: Routledge, 2004.

KNIGHT III, George W. The Pastoral Epistles. Grand Rapids, Michigan/Carlisle: William B. Eerdmans Publishing Company e The Paternoster Press, 1992. 
KOBELSKI, Paul J. Carta aos Efésios. In: BROWN, Raymond E., FITZMYER, Joseph A. e MURPHY, Roland E. (org.). Novo Comentário Bíblico São Jerônimo: Novo Testamento e Artigos Sistemáticos. São Paulo: Academia Cristã e Paulus, 2011.

KOESTER, Helmut. Ephesos in Early Christian Literature. In: KOESTER, Helmut (org.). Ephesos Metropolis of Asia: An Interdisciplinary Approach to its Archaeology, Religion and Culture. Harvard: Harvard University Press, 1995.

Introdução ao Novo Testamento: 1. História, cultura e religião no período helenístico, 2a reimpressão. São Paulo: Editora Paulus, 2012.

Introdução ao Novo Testamento: 2. História e literatura do cristianismo primitivo, $2^{\mathrm{a}}$ reimpressão. São Paulo: Editora Paulus, 2012.

KÜMMEL, Werner Georg. Introdução ao Novo Testamento, $3^{\mathrm{a}}$ Ed.. São Paulo: Editora Paulus, 2004.

LAYTON, Bentley. The Gnostic scriptures. Nova York: Doubleday, 1995.

LEAHY, Thomas W. Epístola de Tiago. In: BROWN, Raymond E., FITZMYER, Joseph A. e MURPHY, Roland E. (org.). Novo Comentário Bíblico São Jerônimo: Novo Testamento e Artigos Sistemáticos. São Paulo: Academia Cristã e Paulus, 2011.

LIEU, Judith M. Christian Identity in the Jewish and Graeco-Roman World. Oxford: Oxford University Press, 2004.

MALINA, Bruce J. Social levels, morals and daily life. In: ESLER, Philip F. (org.). The early Christian world. Nova York: Routledge, 2000.

MARGUERAT, Daniel. A primeira história do cristianismo: Os Atos dos Apóstolos. São Paulo: Editora Paulus e Editora Loyola, 2003.

MARTIN, Clarice J. The eyes have it: Slaves in the communities of Christ-believers. In: HORSLEY, Richard A. (org.). A people's history of Christianity, Vol. 1: Christian origins. Minneapolis: Fortress Press, 2005.

MASON, Steve N.. Philophiai: Graeco-Roman, Judean and Christian. In: KLOPPENBORG, John S. e WILSON, Stephen G.. Voluntary associations in the Graeco-roman world. Nova York: Routledge, 1996.

MATTINGLY, David. The Imperial Economy. In: POTTER, David S. (org.). A Companion to the Roman Empire. Malden: Blackwell Publishing, 2006.

MCCREADY, Wayne O.. Ekklésia and voluntary associations. In: KLOPPENBORG, John S. e WILSON, Stephen G.. Voluntary associations in the Graeco-roman world. Nova York: Routledge, 1996. 
MEEKS, Wayne A.. Os primeiros cristãos urbanos: O mundo social do apóstolo Paulo. São Paulo: Academia Cristã e Editora Paulus, 2011.

Social and ecclesial life of the earliest Christians. In: MITCHELL,

Margaret M. e YOUNG, Frances M.. The Cambridge History of Christianity, vol. I: Origins to Constantine. Cambridge: Cambridge University Press, 2006.

MEIER, John P. Antioch. In: BROWN, Raymond E. e MEIER, John P. Antioch \& Rome:

New Testament Cradles of Catholic Christianity. Nova York/Mahwah, Nova Jersey: Paulist Press, 2004.

MENDES, Norma Musco. O Sistema Político do Principado. In: SILVA, Gilvan Ventura da, e MENDES, Norma Musco. Repensando o Império Romano: Perspectiva Socioeconômica, Política e Cultural. Rio de Janeiro: Mauad Editora, 2006.

MITCHELL, Margaret M.. The emergence of the written record. In: MITCHELL, Margaret M. e YOUNG, Frances M. (org.). The Cambridge History of Christianity, vol. I: Origins to Constantine. Cambridge: Cambridge University Press, 2006.

Gentile Christianity. In: MITCHELL, Margaret M. e

YOUNG, Frances M.. The Cambridge History of Christianity, vol. I: Origins to Constantine. Cambridge: Cambridge University Press, 2006.

MOFFATT, James. An introduction to the literature of the New Testament. Nova York: Charles Scribner's Sons, 1918.

MOMigliANO, Arnaldo. As Raízes Clássicas da Historiografia Moderna. Bauru: EDUSC, 2004.

MORESCHINI, Claudio e NORELLI, Enrico. Early Christian Greek and Latin Literature. Peabody, Massachussets: Hendrickson Publishers, 2005.

MURPHY-O'CONNOR, Jerome. Paulo de Tarso: História de um Apóstolo. São Paulo: Editora Paulus e Edições Loyola, 2013.

Segunda Carta aos Coríntios. In: BROWN, Raymond E., FITZMYER, Joseph A. e MURPHY, Roland E. (org.). Novo Comentário Bíblico São Jerônimo: Novo Testamento e Artigos Sistemáticos. São Paulo: Academia Cristã e Paulus, 2011.

MYLLYKOSKI, Matti. Cerinthus. In: MARJANEN, Antti e LUOMANEN, Petri. A Companion to Second-Century Christian “Heretics”. Leiden: Brill, 2008.

PAGELS, Elaine. The Gnostic Gospels. Nova York: Vintage Books, 1979. 
PERKINS, Pheme. As Epístolas Joaninas. In: BROWN, Raymond E., FITZMYER, Joseph A. e MURPHY, Roland E. (org.). Novo Comentário Bíblico São Jerônimo: Novo Testamento e Artigos Sistemáticos. São Paulo: Academia Cristã e Paulus, 2011.

PRICE, Simon. Religious Mobility in the Roman Empire. In: Journal of Roman Studies, $102,2012$.

PURCELL, Nicholas. The Ancient Mediterranean. In: HORDEN, Peregrine e KINOSHITA, Sharon. A Companion to Mediterranean History. Oxford: Wiley Blackwell, 2014.

QUINN, Jerome D.. The letter to Titus: A new translation with notes and commentary and an introduction to Titus, I and II Timothy, the Pastoral Epistles. Londres: Yale University Press, 2005.

RAPP, Claudia. Holy Bishops in Late Antiquity: The Nature of Christian Leadership in an Age of Transition. Londres: University of California Press, 2005.

REMUS, Harold. Voluntary Associations and Networks: Aelius Aristides at the Asclepieion in Pergamum. In: KLOPPENBORG, John S. e WILSON, Stephen G.. Voluntary associations in the Graeco-roman world. Nova York: Routledge, 1996.

REUMANN, John. Philippians: A new translation with introduction and commentary. Londres: Yale University Press, 2008.

RHODES, P. J. Aristotle: Athenian Constitution. Londres: Penguin Books, 1984.

ROBINSON, Thomas A. Ignatius of Antioch and the Parting of the Ways: Early JewishChristian Relations. Peabody, Massachusetts: Hendrickson Publishers, 2009.

ROHRBAUGH, Richard L. The Jesus tradition: The gospel writers' strategies of persuasion. In: In: ESLER, Philip F. (org.). The early Christian world. Nova York: Routledge, 2004.

ROSENMEYER, Patricia A. Ancient Epistolary Fictions: The letter in Greek literature. Cambrige: Cambridge University Press, 2001.

ROSTOVTZEFF, Mikhail. Social and economic history of the Roman Empire. Londres: Clarendon Press, 1957.

SANDERS, Ed Parish. Paulo, a Lei e o Povo Judeu. São Paulo: Academia Cristã e Editora Paulus, 2009.

SARTRE, Maurice. Le Haut-Empire romain: Les provinces de Mediterranée orientale d'Auguste aux Sévères. Paris: Éditions du Seuil, 1991.

SELVATICI, Mônica. Construção de fronteiras entre o judaísmo e o cristianismo no Império Romano: os judaizantes e a retórica antijudaica no movimento cristão dos séculos 
I e II d. C. In: Romanitas - Revista de Estudos Grecolatinos, n. 1, pp. 23-37. Vitória: LEIR-ES, 2013.

SHAW, Brent D. Rebels and outsiders. In: BOWMAN, Alan K., GARNSEY, Peter e RATHBONE, Dominic. The Cambridge Ancient History, Volume IX: The High Empire, A.D. 70-192. Cambridge: Cambridge University Press, 2000.

SHOEMAKER, Stephen J. Early Christian Apocryphal Literature. In: HARVEY, Susan Ashbrook e HUNTER, David G. (org.). The Oxford Handbook of Early Christian Studies. Nova York: Oxford University Press, 2008.

SIMON, Marcel. Verus Israel: A Study of the Relations between Christians and Jews in the Roman Empire AD 135-425. Oxford/Portland, Oregon: The Littman Library of Jewish Civilization, 1986.

SIMON, Marcel e BENOIT, André. Judaísmo e Cristianismo Antigo de Antíoco Epifânio a Constantino. São Paulo: EDUSP e Pioneira, 1987.

SIKER, Jeffrey S.. Christianity in the second and third centuries. In: ESLER, Philip F.. The early Christian world, Nova York: Routledge, 2004.

STE. CROIX, G. E. M. de. The Class Struggle in the Ancient Greek World: From the Archaic Age to the Arab Conquests. Ithaca: Cornell University Press, 1981.

TALBERT, Richard J. A. The Senate of Imperial Rome. Princeton: Princeton University Press, 1984.

THERON, Daniel J. Evidence of Tradition: Selected Source Material for the Study of the History of the Early Church, the New Testament Books, and the New Testament Canon. Grand Rapids: Baker Book House, 1957.

THOMPSON, Michael B. The Holy Internet: Communication Between Churches in the First Christian Generation. In: BAUCKHAM, Richard (org.). The Gospels for All Christians: Rethinking the Gospel Audiences. Grand Rapids, Michigan/Cambridge, RU: William B. Eerdmans Publishing Company, 1998.

TORJESEN, Karen Jo. Clergy and Laity. In: HARVEY, Susan Ashbrook e HUNTER, David G. (org.). The Oxford Handbook of Early Christian Studies. Nova York: Oxford University Press, 2008.

TREBILCO, Paul. The Early Christians in Ephesus from Paul to Ignatius. Grand Rapids, Michigan/Cambridge, RU: William B. Eerdmans Publishing Company, 2004.

TREVETT, Christine. A Study of Ignatius of Antioch in Syria and Asia. Lampeter, País de Gales: The Edwin Mellen Press, 1992. 
VASCONCELlOS, Pedro L. e FUNARI, Pedro Paulo A. Paulo de Tarso: Um apóstolo para as nações. São Paulo: Paulus, 2013.

VENDRAME, Calisto. A escravidão na Bíblia: Com uma reflexão preliminar sobre a escravidão no mundo greco-romano e na civilização ocidental. São Paulo: Ática, 1981. VERMES, Geza. Quem é Quem na Época de Jesus. Rio de Janeiro: Editora Record, 2008. VINZENT, Markus. Rome. In: MITCHELL, Margaret M. e YOUNG, Frances M.. The Cambridge History of Christianity, vol. I: Origins to Constantine. Cambridge: Cambridge University Press, 2006.

YARBRO COLLINS, Adela. Apocalipse. In: BROWN, Raymond E., FITZMYER, Joseph A. e MURPHY, Roland E. (org.). Novo Comentário Bíblico São Jerônimo: Novo Testamento e Artigos Sistemáticos. São Paulo: Academia Cristã e Paulus, 2011.

WILD, Robert A. As Cartas Pastorais. In: BROWN, Raymond E., FITZMYER, Joseph A. e MURPHY, Roland E. (org.). Novo Comentário Bíblico São Jerônimo: Novo Testamento e Artigos Sistemáticos. São Paulo: Academia Cristã e Paulus, 2011.

WILSON, S. G. Voluntary associations: An overview. In: KLOPPENBORG, John S. e WILSON, Stephen G.. Voluntary associations in the Graeco-roman world. Nova York: Routledge, 1996. 
Anexo

Mapa com as cidades do Mediterrâneo que contavam com igrejas ao fim do século I d.C., incluindo as relacionadas ao itinerário de Inácio de Antioquia

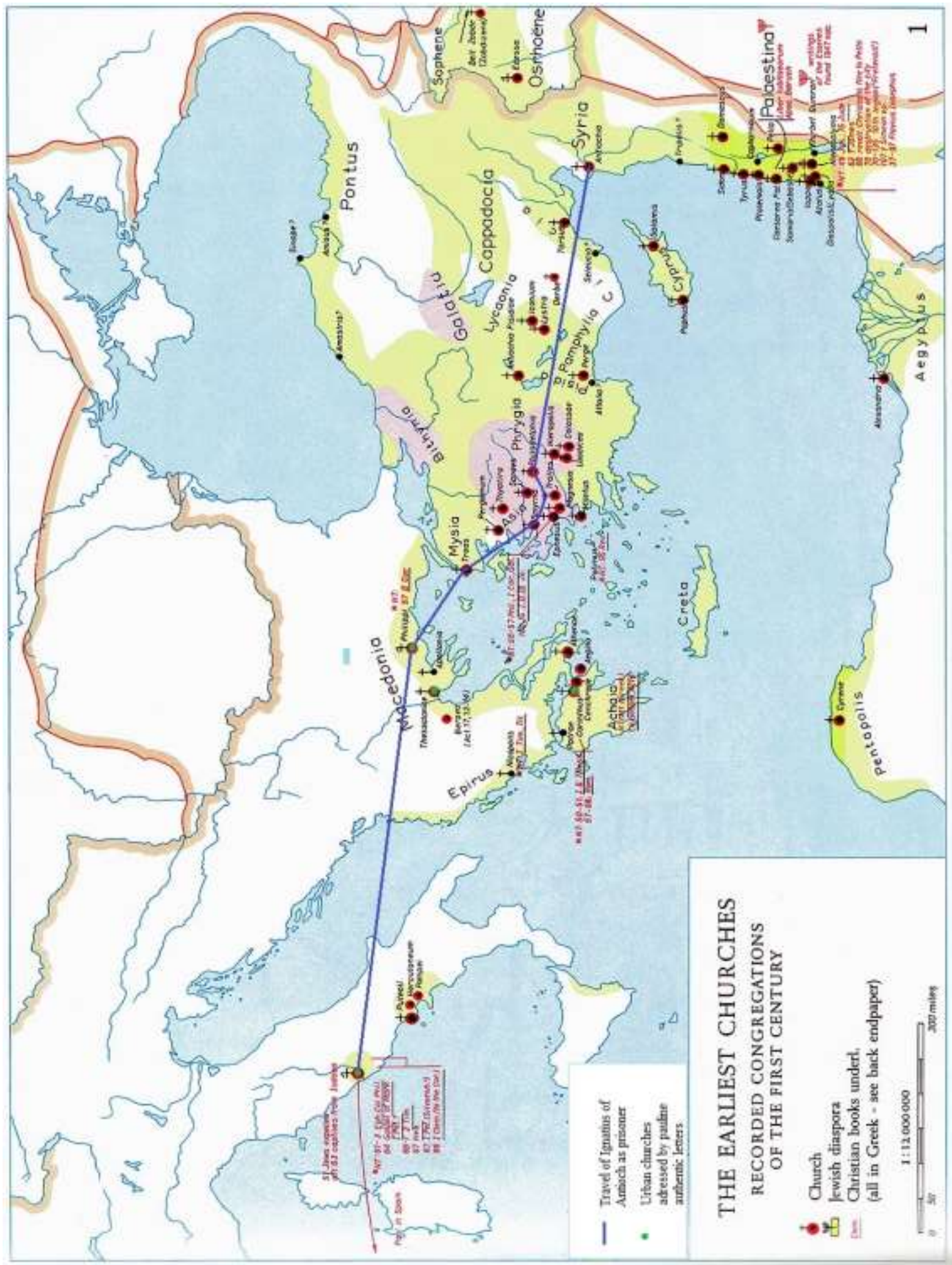

Fonte: CARRINGTON, Philip. The Early Christian Church. Cambridge: Cambridge University Press, 1957 (tabela superior acrescentada). Localidades e datações da documentação neotestamentária são próprias do autor, não refletindo a posição expressa na dissertação. 